UNIVERSIDADE DE SÃO PAULO

ESCOLA DE COMUNICAÇÕES E ARTES

Programa de Pós-Graduação em Ciências da Comunicação

Teoria e Pesquisa em Comunicação

Linguagens e Estéticas da Comunicação

Tomaz Affonso Penner

O UNIVERSO NARRATIVO DE LATITUDES: UM ESTUDO DE CASO DAS ESTRATÉGIAS DE TRANSMIDIAÇÃO EM UMA PRODUÇÃO FICCIONAL BRASILEIRA

São Paulo 


\section{TOMAZ AFFONSO PENNER}

O Universo Narrativo de Latitudes: um estudo de caso das estratégias de transmidiação em uma produção ficcional brasileira

Dissertação apresentada junto ao Programa de Pós-Graduação em Ciências da Comunicação da Escola de Comunicações e Artes da Universidade de São Paulo como requisito parcial para obtenção do título de Mestre em Ciências da Comunicação.

Área de concentração: Teoria e Pesquisa em Comunicação

Linha de pesquisa: Linguagens e Estéticas da Comunicação

Orientadora: Profa. Dra. Maria Cristina Palma Mungioli

São Paulo 
BANCA EXAMINADORA

São Paulo

2016 


\section{AGRADECIMENTOS}

Agradeço primeiramente à minha família. Ao meu irmão, Leo, e aos meus pais, Lilia e Tim, pelo apoio incondicional e por encararem meus sonhos como se fossem seus. Sem a força de vocês, nada disso seria possível. À minha tia Suzana, pelo abrigo nos primeiros tempos de vida nova e pelo carinho de sempre. Ao tio Dré, Fernanda e Alice, por mostrarem que existe amor e família em SP. À vó Consuelo e todas as tias Affonso, que acreditaram em mim mesmo quando nem eu acreditava. À vó Nite, que, se estivesse por aqui, seria a mais estusiasmada com o percurso que escolhi seguir.

Agradeço ao Marcelo, por me mostrar caminhos novos e bonitos e trilhá-los comigo daqui até onde a gente quiser. O mundo é nosso.

Agradeço a todos os professores com quem tive contato ao longo do mestrado. Especialmente à minha orientadora, Profa. Dra. Maria Cristina Palma Mungioli, por todas as trocas, ensinamentos, por me colocar no eixo sempre que meu temperamento de sagitário apontava longe demais no horizonte. Principalmente, pela relação afetuosa que ultrapassa a impessoalidade dos corredores acadêmicos. À Profa. Dra. Maria Immacolata Vassallo de Lopes, com quem aprendi muito sobre rigor e paixão pela ciência. Ao Prof. Dr. João Carlos Massarolo e à Profa. Dra. Mayra Rodrigues Gomes, pelas contribuições preciosas que ajudaram na construção desse trabalho.

Agradeço aos colegas da Universidade de São Paulo que se tornaram amigos: Clarice, Rafa, Ligia, Issaaf, Luiza, Helen, Pedro, Fernanda, Silvia, Anderson, Rosana, Cacau e alguns outros que não apenas passaram, mas ficaram. $\mathrm{Na}$ biblioteca ou no bar, os encontros com vocês são sempre estimulantes.

Agradeço aos amigos de São Paulo, que tornaram a vida na cidade grande mais leve. Thiago, Bianca, Kamila, Preta, Otávio, Mayrinck, Yuri e Andreza. Também aos que ficaram em Belém ou se espalharam por outros lugares do mundo, mas estiveram presentes ouvindo queixas e crises por qualquer dispositivo a partir do qual pudemos nos comunicar: Paula, Baia, Moenah, Fernando, Andrea, Lulu e Lili.

Por fim, agradeço ao CNPq pelo auxílio financeiro para a realização dessa pesquisa.

Somos mais fortes juntos. Meu muito obrigado! 
Acontecimentos de importância histórica transformaram o cenário social da vida humana. Uma revolução tecnológica concentrada nas tecnologias da informação começou a remodelar a base material da sociedade.

(Castells, 2006, p. 39) 


\title{
O universo narrativo de Latitudes: um estudo de caso das estratégias de transmidiação em uma produção ficcional brasileira
}

\begin{abstract}
RESUMO
A dissertação ora apresentada teve como objetivo central identificar e sistematizar as estratégias de transmidiação desenvolvidas no âmbito da produção da obra ficcional Latitudes $(2013,2014)$, um projeto transmídia veiculado em três plataformas diferentes: YouTube, televisão e cinema e, respectivamente, em três formatos: websérie, série de TV e longa metragem. Trata-se de pesquisa que utiliza a técnica de estudo de caso para analisar o surgimento de obras ficcionais produzidas para distribuição em diversas plataformas $O$ trabalho discute $o$ surgimento de novos gêneros e formatos relacionando-os ao contexto da hipertelevisão (Scolari, 2014) e da distribuição de conteúdos em multiplataformas, que marca a experiência estética audiovisual na contemporaneidade, proporcionando novas formas de produção, consumo e fruição. Também são discutidos modelos de negócio na cultura da convergência (Jenkins, 2008), nomeadamente no YouTube - repositório para a websérie Latitudes -, a partir da distribuição e consumo cada vez mais pautados em plataformas streaming, que ganham espaço frente à grade horária tradicional televisiva, no modelo broadcast. Apoiados nos estudos de linguagem de Bakhtin (2003) e em discussões sobre gêneros feitas por Barthes (2009), Eco (1994) e Mungioli (2012), os resultados das análises sugere uma aproximação entre os gêneros ficcional e documental na versão seriada exibida na televisão. Em termos de estratégias de transmidiação desenvolvidas em Latitudes, a análise revelou que a obra incorpora modelos de distribuição e consumo que se apresentam como tendências atuais na produção audiovisual brasileira. Quanto à construção narrativa, observamos como principais resultados o uso das estratégias de propagação (Fechine, 2013) e de reassistibilidade (Mittel, 2011) para o estabelecimento da transmidiação em Latitudes. Também incorporamos às discussões a análíse de estratégias de product placement, a partir de inserções roteirizadas, como modelo de capitalização eficaz em produtos audiovisuais que contam com a internet como principal veículo de distribuição.
\end{abstract}

Palavras-chave: Latitudes; estratégias de transmidiação; formatos audiovisuais; YouTube; transmídia storytelling. 


\title{
The narrative universe of Latitudes: a case study of transmediation strategies in one Brazilian fictional production
}

\begin{abstract}
The present study aims to identify and systematize transmediation strategies developed by the producers of the series Latitudes $(2013,2014)$, a project distributed in three different platforms: internet (YouTube), television and cinema (so, in three formats: webseries, TV series and film). The work discusses the emergence of new genres and formats relating them to the context of hipertelevision (Scolari, 2014) and the multi-platform content distribution, which marks the audiovisual experience in contemporary culture and ensures more autonomy and agency to the audiences (Castells, 2009). We also discuss the new business opportunities in the convergence culture (Jenkins, 2008), particularly on YouTube, which works as a repository for the webseries Latitudes, with the distribution and consumption increasingly guided by streaming platforms, that are gaining ground against the traditional television broadcast model. It was also possible to see that these new dynamics, supported by the Internet, create new production processes. Based on the Language theory of Bakhtin (2003) and reflections on genres using Barthes (2009), Eco (1994) and Mungioli (2012). Through these analyzes, we see a connection between the fictional and documentary genres in the television version of our empirical object. After these advances, we reach the stage of systematization of transmediation strategies developed in Latitudes, realizing that it incorporates different kinds of distribution and consumption that are presented as trends in the Brazilian audiovisual production. As main results, we identified propagation strategies (Fechine, 2013), and the use of rewatchability (Mittel, 2011) for the establishment of transmidiation in Latitudes. We also add to the discussion the strategy of product placement (Miller, 2014), through scripted insertions, as an effectively capitalization model for audiovisual products that rely on the internet as a primary vehicle of distribution.
\end{abstract}

Key-words: Latitudes; transmediation strategies; audiovisual formats; YouTube; transmedia storytelling. 


\section{SUMÁRIO}

INTRODUÇÃO

CAPÍTULO 1: TELEVISÃO EM TRANSFORMAÇÃO

1.1.TV: do contrato pedagógico à era multiplataforma

\section{CAPÍTULO 2: METODOLOGIA E PROCEDIMENTOS}

METODOLÓGICOS

2.1. Procedimentos

CAPÍTULO 3: LOCALIZANDO LATITUDES

\section{CAPÍTULO 4: A PRODUÇÃO FICCIONAL EM TEMPO DE}

$\begin{array}{ll}\text { TRANSMIDIAÇÃO } & 70\end{array}$

$\begin{array}{ll}\text { 4.1. Grade de programação: fluxo e arquivo } & 71\end{array}$

4.2. Aumento da produção audiovisual nacional: a lei do cabo 75

4.3. Narrativas transmídia $\quad 81$

4.4. Transmidiação: uma tendência na produção ficcional brasileira? 85

4.5. Latitudes: a matriz de produção para a internet 90

CAPÍTULO 5: YOUTUBE: A NOVA FRONTEIRA 95

5.1. Trânsito de conteúdos audiovisuais entre plataformas online e offline 96 
5.2. Disponibilização da produção televisiva na internet

5.3. Consumo audiovisual no YouTube e novos modelos de negócio

5.4. A cultura do storytelling: as narrativas das marcas

6.1. Gêneros e Discursos no estudo de Latitudes

6.2. Injunções sociais e plasticidade dos gêneros

6.3. Alguns elementos da estética da produção online

6.4. Latitudes entre narrativas e linguagens

6.5. Entrecruzamentos estéticos das plataformas: a (des) construção de temporalidades e ritmos

6.6. Gênero ficcional e documentário: uma aproximação

\section{CAPÍTULO 7: AS ESTRATÉGIAS DE TRANSMIDIAÇÃO}

EM LATITUDES

7.1. As estratégias de Propagação e Expansão

7.2. Reassistibilidade e Cenas Deletadas

7.2.1. Reassistindo Latitudes

7.3. Latitudes dos não-lugares

7.4. Inserção mercadológica: product placement

7.5. O gancho e a fruição em streaming 


\section{LISTA DE FIGURAS}

Figura 1. Paris 44

$\begin{array}{ll}\text { Figura 2. Londres } & 47\end{array}$

Figura 3. Desfile em Londres 49

Figura 4. Veneza $\quad 50$

Figura 5. Shooting em Veneza 51

Figura 6. José Ignacio

Figura 7. Merchandising P\&G em São Paulo 56

Figura 8. São Paulo $\quad 57$

Figura 9. Product Placement Gillette 58

$\begin{array}{ll}\text { Figura 10. Porto } & 60\end{array}$

Figura 11. Buenos Aires

Figura 12. Varela Varelita 63

$\begin{array}{ll}\text { Figura 13. Istambul } & 65\end{array}$

Figura 14. Mapa de destinos em Latitudes $\quad 67$

$\begin{array}{ll}\text { Figura 15. Anúncio gráfico: banner } & 107\end{array}$

$\begin{array}{ll}\text { Figura 16. Anúncio de texto no YouTube } & 108\end{array}$

$\begin{array}{ll}\text { Figura 17. Anúncio em vídeo no YouTube } & 109\end{array}$

$\begin{array}{ll}\text { Figura 18. Transformação de Olívia (Alice Braga) } & 164\end{array}$ 


\section{LISTA DE TABELAS}

$\begin{array}{ll}\text { Tabela 1. Scolari e Castells } & 27\end{array}$

Tabela 2. Investimentos publicitários $2015 \quad 89$

Tabela 3. Categorias dos conteúdos extra-ficcionais 136

Tabela 4. Formatos de inserção dos conteúdos extra-ficcionais 137

Tabela 5. Estratégias e conteúdos transmídia 146 


\section{LISTA DE GRÁFICOS}

Gráfico 1. Ranking das redes de TV 28

Gráfico 2. Emissoras controladas por parlamentares 29

$\begin{array}{lr}\text { Gráfico 3. Crescimento de associados à ABPI-TV } & 80\end{array}$

$\begin{array}{ll}\text { Gráfico 4. Conteúdos extra-ficcionais de Latitudes } & 138\end{array}$

Gráfico 5. Formatos de inserção dos conteúdos extra-ficcionais 139 


\section{INTRODUÇÃO}

Para começar a entender o interesse pelo tema proposto nessa dissertação, é importante voltar um pouco e contar uma parte da minha trajetória. Entre 2010 e 2013, trabalhei como produtor transmídia em um projeto de divulgação da ciência no Museu Paraense Emílio Goeldi (MPEG), uma instituição de pesquisa em Belém. Fundado em 1866, o Museu, como costumo chamá-lo, tem várias iniciativas relacionadas à conservação biológica e histórica da região amazônica e o trabalho desenvolvido pela equipe de comunicação incluía acompanhar as expedições científicas de campo com fins de documentação e compartilhamento dos resultados alcançados.

Uma das viagens acompanhadas pela equipe de comunicação, da qual eu fazia parte, foi a Monte Alegre, cidade com 56 mil habitantes que fica a 776 quilômetros de Belém. Localizado no oeste do Pará, o município se diferencia das planícies características do estado, apresentando chapadas em toda a sua extensão. A exemplo de grande parte das cidades ao norte do Brasil, a atividade econômica mais desenvolvida em Monte Alegre é a agropecuária.

Ao lado de Lagoa Santa (MG) e da Serra da Capivara (PI), Monte Alegre está entre os maiores sítios arqueológicos do Brasil. Além dos chapadões, o que distingue a localidade dos outros municípios da região é o que encontramos dentro de grutas e no alto dos vários montes de desenham a sua geografia: pinturas rupestres. Visitar esses lugares é perceber como o registro das imagens já era importante para a subjetividade humana há 10,15 mil anos.

As pinturas em questão retratam o modo de vida das populações daquele

lugar, ilustrando desde caçadas até rituais sagrados. É com base em registros desse tipo que podemos ter pistas do comportamento, hábitos e relações sociais de povos que ocupavam a região há alguns milênios. Desde a pintura rudimentar feita com urucum, sangue de animais e barro às imagens em movimento acessadas pela internet a partir de nossos aparelhos celulares, essas modalidades de registros nos levam a refletir sobre o poder da imagem na constituição histórica da humanidade e de como elas se desenvolveram lado a lado

Registrando essas imagens estáticas e milenares, meu trabalho consistia na realização de produtos de divulgação explicando a história dos povos originais da 
região e os processos desenvolvidos pelos pesquisadores ali. Era preciso pensar em como colocar aquelas imagens originalmente inertes em movimento e distribuí-las entre diversos suportes - o trabalho referente às pinturas rupestres de Monte Alegre virou um livro de ilustrações e poemas, uma exposição, diversos vídeos para as redes sociais e uma websérie.

Desde então a compreensão de funcionamento do trânsito de conteúdos entre diversas plataformas se tornou um tema de muito interesse para mim. Quais as melhores estratégias para que produções audiovisuais circulem online e offline, de que maneira elas chegam mais contundentemente aos seus públicos? Ao ingressar no Mestrado em Ciências da Comunicação da Universidade de São Paulo, em 2014, me deparei com o universo das narrativas ficcionais e aí foi unir o útil ao agradável para desenvolver o projeto que deu origem à presente dissertação.

A partir da realização da disciplina da pós-graduação Narrativas Televisuais e Identidades, conheci uma obra ficcional seriada que inovava em seus processos de produção, distribuição e consumo no Brasil. Transitava entre formatos e suportes como um projeto transmídia concebido para priorizar as redes e novos modelos de negócio fora da lógica broadcast. Foi encantamento à primeira vista e instantaneamente veio o grande desejo de desvendar as novidades que Latitudes apresenta para a realização audiovisual no país.

Era necessário, entretanto, delimitar a proposta de estudo, e decidimos trabalhar com as estratégias de transmidiação de Latitudes, partindo da hipótese de que elas se configuram como uma tendência dos novos tempos da produção ficcional brasileira. Tendência que nos leva a algumas perspectivas de democratização da produção ficcional audiovisual por meio do crescimento de acesso à internet e às tecnologias da informação e da comunicação.

Para começar, lembremos que Latitudes é marcada por um momento histórico que permitiu a sua realização e ao qual necessariamente está submetida. No primeiro capítulo, começamos a discussão dessa pesquisa apontando o histórico da concentração midiática brasileira, que marcou o surgimento e a expansão da televisão no país. Esse cenário gera um mercado hegemônico no qual poucas emissoras produzem conteúdos relevantes nas métricas de audiências nacionais. Emissoras que deveriam, por princípio constitucional, atender a necessidades sociais do país e à difusão de informação e de cultura, o que pouco acontece devido ao caráter prioritariamente comercial que assumiram em seu percurso histórico, 
Nesse modelo de desenvolvimento estabelecido, grande parte da indústria de comunicação brasileira está concentrada inclusive nas mãos de pessoas detentoras de cargos eletivos no Executivo ou no Legislativo. Percebe-se, desse modo, uma relação íntima entre o poder político e o poder midiático brasileiros, em um processo de retroalimentação no qual o poder político usa o poder midiático para expandir sua ideologia e o poder midiático usa o poder político para se legitimar, visto o sistema de concessões públicas dos meios de comunicação adotado no Brasil. Desse modo, mesmo que um canal de radiodifusão ou televisivo não cumpra as funções sociais previstas constitucionalmente, ele se mantém no ar devido à influência política dos grupos que o compõem.

É nesse ambiente que a TV nacional se desenvolve, e é essa realidade que passa a ser sutilmente contestada a partir do surgimento de novas perspectivas de distribuição e de consumo audiovisual. Apoiamo-nos em Scolari (2014), para definir que a hipertelevisão estende seus braços ao redor do mundo conectado à internet, por mais que haja resistência dos donos da mídia tradicional no Brasil. O aparelho de televisão deixa, nesse contexto, de ser a única maneira de acesso aos conteúdos televisivos. Aplicativos de tablets e smartphones, sites de distribuição em streaming e mesmo operadoras de conteúdos on demand que oferecem seus serviços em Smart TVS fazem parte do cotidiano de uma fatia crescente da população mundial e brasileira.

Vale lembrar que, por mais presentes que sejam as tecnologias digitais no mercado televisivo nacional, ele continua tendo como seu maior expoente cultural a ficção seriada televisiva. A telenovela brasileira aparece como nosso grande produto de exportação midiática e responsável pela potência produtiva nacional, contrariando previsões do norte econômico global, que por vezes taxou países latino-americanos como previsíveis polos de importação de conteúdos audiovisuais de entretenimento. Mais do que isso, a ficção seriada se configura como uma narrativa da nação (Lopes, 2003), por trazer ao (grande) público as histórias dos Brasis, desde o país urbano até as profundezas rurais de nosso território.

É, portanto, previsível que muitas experimentações e inovações de formatos da produção audiovisual, frente a esse contexto de expansão das tecnologias digitais, ocorram no campo da ficção e, além disso, da ficção seriada. Afinal, esse gênero tem um forte apelo, que reside na construção do hábito. Exatamente por isso, é também facilmente assimilado por audiências acostumadas ao consumo de 
ficção, que penetra todas as classes e a maior parte das distribuições geográficas do cenário brasileiro, em circulação no país já há mais de 50 anos.

Estabelecida essa conjuntura que justifica a escolha de um objeto empírico inserido no contexto digital e da ficção seriada, seguimos a discussão apresentando nosso aporte metodológico, no decorrer do segundo capítulo. O terceiro se dedica à explicação detalhada da obra, a partir da apresentação de sinopses de cada um dos webisódios que compõem a narrativa.

Latitudes é apresentada como uma narrativa que inova principalmente em seu modelo de distribuição, possível a partir de uma conjuntura propícia no mercado audiovisual brasileiro. Conforme explicamos no quarto capítulo, o contexto de produção do título é marcado por ações afirmativas no sentido de democratizar a produção audiovisual do país, a partir de algumas mudanças legais, cujas determinações alteraram as grades horárias das emissoras de TV paga brasileiras. Aos poucos, se observa a constituição de um cenário menos hegemônico, quebrando paulatinamente a tradição midiática nacional.

Falamos da lei 12.485, de 2011, popularmente conhecida como lei do cabo. A partir da obrigatoriedade progressiva de inclusão de conteúdos nacionais na grade de programação de canais da Pay TV, a norma busca que os espaços qualificados (emissoras que exibam prioritariamente séries, filmes, animações e documentários) ocupem mais suas grades horárias com programação brasileira.

A medida acabou encorajando diretamente o crescimento da produção audiovisual nacional. Além disso, um dos pontos estabelecidos pela lei exige que metade da programação cotada para conteúdos nacionais seja feita por produtoras independentes, o que estimulou o crescimento desse tipo de empreendimento no país. Latitudes entra no rol de produções nacionais feitas nesse modelo fora do eixo da grande indústria de mídia tradicional.

Esse movimento não seria possível sem a força da internet como nova variável do mercado de entretenimento - de ficção seriada e da Comunicação de maneira geral. Estamos, portanto, em um cenário com duas grandes mudanças identificadas nessa pesquisa: por um lado, o estímulo à realização nacional independente por meio de leis de incentivo e, por outro, a popularização da internet como veículo de mídia para a produção audiovisual.

A conjuntura, apresentada até esse ponto da dissertação, gera uma mudança gradual no paradigma de produção, distribuição e consumo audiovisual. Apesar de 
ainda não estar totalmente estabelecida e as mídias tradicionais ainda terem muita força no mercado brasileiro, essa é uma tendência que aponta para a criação de novos formatos e práticas nesse campo. Uma das grandes transformações que entram em cena é a progressiva transição do modelo de fluxo para o modelo de arquivo (Fiske, 1987). Enquanto o fluxo é compreendido como a cadência tradicional da televisão, que atende às necessidades da grade horária e tem uma programação fixa, o arquivo responde a novos modelos de distribuição, potencializados com a internet, nos quais os conteúdos são disponibilizados on demand e acessados de acordo com a vontade ou necessidade das audiências.

Desse modo, os hábitos de audiência vêm sendo transformados. À medida que é cada vez menos comum que o espectador precise se sentar em frente à televisão e esperar seu programa favorito começar para ter acesso a ele, as grandes emissoras precisam rever o modelo broadcast, historicamente regulador de seus conteúdos. Muitos setores da audiência já não lidam bem com a grade de programação e aceitaram sem problemas a lógica streaming. É interessante pensar no sentido de repositório que muitos sites e operadoras on demand assumiram. Ao invés de produtos com data e hora para exibição, há espaços onde os conteúdos estão sempre disponíveis e podem ser acessados a partir de diversas plataformas.

Nesse contexto, Latitudes se configura como uma produção que se beneficiou (e, quem sabe, só foi possível a partir da) lei do cabo, mas que se inseriu profundamente nas plataformas digitais. A partir de sua distribuição em três mídias distintas, a pesquisa aponta a relevância que o YouTube assume na composição do projeto transmídia dirigido por Felipe Braga, uma vez que o site comporta toda a diegese da trama e seus eixos centrais. Nesse ponto do desenvolvimento do trabalho, conseguimos cumprir um objetivo importante ao qual nos propusemos desde o princípio: localizar a nave-mãe (Jenkins, 2008) de Latitudes, que está situada na internet - em uma disposição incomum no Brasil. O que se observa normalmente, em relações de transmidiação que envolvem internet e televisão ou internet e cinema, é a narrativa central se concentrar nos filmes ou nas produções de ficção televisiva, de modo que a internet atua como satélite para aglutinar conteúdos que complementam as histórias contidas em outras mídias.

Tendo em vista essa característica, nos dedicamos à compreensão do percurso traçado no projeto transmídia Latitudes entre a nave-mãe e as demais plataformas de distribuição estabelecidas pela produção da obra. Como resultado 
principal dessa etapa, identificamos a centralidade da narrativa no YouTube, que tematiza o quinto capítulo desse trabalho - dedicado a discussões sobre os tipos de conteúdos disponibilizados na rede e novos modelos de negócios possíveis a partir da lógica streaming.

Sobre a transposição entre as plataformas, no sexto capítulo é realizada uma análise empírica das mudanças de linguagem e formato estabelecidas para que o projeto transmídia passasse do YouTube para a TNT ${ }^{1}$. Escolhemos esse "trajeto" pelas características únicas que a televisão aglutina no processo em questão, contando com cenas inéditas de Latitudes, o que não acontece no longa metragem. Enquanto o filme é composto por uma montagem de todos os webisódios da websérie, sem grandes interferências, a série televisionada traz conteúdos exclusivos e mudanças importantes na narrativa, com seus extras de produção.

Percebemos, a partir da análise, que as e extensões com conteúdos de fora da diegese disponibilizadas exclusivamente na televisão dão novas ferramentas de interpretação às audiências, além de revelarem elementos exclusivos de realização da obra, levando os leitores a um outro nível de fruição. Também representam uma aproximação entre o gênero ficcional e o documental.

Trouxemos também exemplos de produções criadas para a internet que foram levadas ao ambiente televisivo e vice-versa, a fim de estabelecer uma breve conjuntura do mercado audiovisual de ficção e entretenimento nacional no trânsito entre suportes. Corroboramos a ideia de tendência de circulação de conteúdos entre as mídias online e offline e chegamos a uma etapa importante do trabalho, que nos leva a entender as plataformas de streaming, especialmente o YouTube, como uma nova fronteira no mercado audiovisual no Brasil.

Nesse ponto, são apresentadas novas perspectivas genéricas e de formatos possíveis a partir das plataformas digitais on demand. Essa análise permite entender de que forma uma produção feita de maneira independente se insere comercialmente no mercado audiovisual brasileiro, não apenas em mídias tradicionais, mas especialmente contando com a internet como seu principal veículo de distribuição. Internet, é bom lembrar, que oferece gratuitamente a maior parte

\footnotetext{
${ }^{1}$ Turnet Network Television, canal da TV paga que exibiu a série Latitudes.

${ }^{2}$ Apesar de distribuído no YouTube, no canal pago TNT e no circuito comercial de cinemas, o projeto transmídia Latitudes foi produzido de maneira independente, com captação de recursos a partir de inserções roteirizadas de marcas parceiras e sem vinculação a grandes produtoras ou emissoras de televisão. Mais aspectos da realização de Latitudes serão trazidos ao longo do
} 
dos conteúdos e que estabelece, portanto, novas lógicas econômicas de compra e venda de espaços e modelos de inserção dos anunciantes.

Após essas etapas cumpridas, chegamos finalmente ao sétimo e último capítulo, que aglutina as análises centrais do trabalho, referentes às estratégias de transmidiação desenvolvidas no polo da produção de Latitudes. O primeiro recorte utilizado foi a categorização em estratégias de Expansão e Propagação (Fechine, 2013), que definem o tipo de recurso utilizado na transposição entre as plataformas. Esse modelo se revelou bastante interessante principalmente devido à sua maleabilidade para trabalhar os conceitos, o que o tornou aplicável fora do contexto de telenovelas para o qual foi originalmente estabelecido.

É interessante perceber que Latitudes percorre um caminho diferente do que é visto tradicionalmente na televisão brasileira. À medida que, em geral, as produções contam com TV ou cinema como as mídias principais de distribuição e recorrem à internet para veicular os conteúdos extras, nosso objeto empírico faz o oposto. A partir da nave-mãe no YouTube, categorizamos individualmente sua transposição para o formato de seriado televisual e de longa metragem, identificando uma composição que se limita a propagar a narrativa ficcional para outras plataformas. Desse modo, percebemos que uma produção transmídia, para que seja categorizada dessa maneira, não necessariamente precisa expandir seu universo ficcional em outras plataformas. É notável que reverberar a narrativa em outras telas se configura como uma estratégia narrativa, e isso nos leva a falar sobre a reassistibilidade (Mittel, 2011).

Apesar de concentrar a narrativa central no YouTube, fez parte das estratégias de distribuição de Latitudes propagá-la em outros veículos. Isso parece estranho a princípio, pois é um modelo que pressupõe que o público esteja disposto a dois comportamentos cada vez mais raros no tempo de popularização da fruição em steaming: 1) esperar a exibição de acordo com a grade horária televivisa ou 2) pagar para acessar os conteúdos (ou com os ingressos do cinema, ou pelo download no iTunes).

No entanto, com o aprofundamento das reflexões para o desenvolvimento dessa pesquisa, identificamos a reassistibilidade como uma estratégia concreta de transmidiação, que leva a novas perspectivas de relacionamento com as audiências e mesmo com os anunciantes. Desse modo, disponibilizar a websérie para acesso gratuito e on demand foi uma experiência que buscou a formação do público, o 
qual, cativo, iria atrás do conteúdo em outras plataformas. Entende-se, portanto, que a televisão poderia servir como suporte para revelar extras de produção aos fãs e o cinema entraria como uma nova experiência com a obra - já conhecida - na grande tela.

Desse modo, além de elevar determinados fãs ao nível de especialistas, devido à imersão multiplataforma na narrativa, Latitudes também cria novas perspectivas de negócios com seus anunciantes. Uma vez que a obra surgiu como um projeto patrocinado, a comercialização dos espaços não se deu exclusivamente da maneira tradicional, com os intervalos comerciais, mas a partir também do product placement composto por anúncios feitos com inserções roteirizadas. Esse modelo também conta com a reassistibilidade para que os parceiros comerciais anunciados nos episódios circulem entre o maior número possível de plataformas, alcançando, desse modo, um público mais amplo. Podemos pensar, por exemplo, que talvez não fosse possível a uma websérie feita de maneira independente e circulando exclusivamente no YouTube ter o patrocínio de grandes marcas globais, como Latitudes teve.

A experimentação contou, portanto, com o YouTube como ferramenta fundamental, mas a estrutura que a produção teve (falando de recursos), talvez só tenha sido possível quando o projeto abraçou também as plataformas tradicionais. De maneira geral, Latitudes chegou às audiências das mídias digitais, mas não deixou de lado o público da TV paga e do circuito brasileiro de cinema.

Apesar disso, é notável a inserção do projeto transmídia nas plataformas digitais e a centralidade do YouTube nesse processo. O formato websérie trouxe o debate sobre os ganchos, que são quase ausentes em Latitudes. Essa ausência se configura como mais uma estratégia de transmidiação identificada, pois permite que o público circule sem muitas restrições entre os fragmentos da obra (webisódios/episódios), em uma lógica cada vez mais comum com a expansão da distribuição em streaming. Nesse contexto, o fator mais importande de marcação dos episódios são as cidades nas quais eles se desenvolvem.

Conforme veremos ao longo do trabalho, cada trecho de Latitudes, na forma episódica, se passa em uma cidade diferente ao redor do mundo. Percorrem oito destinos, entre Europa, Ásia e América do Sul, e, apesar dessa riqueza de cenários, a narrativa ocorre quase integralmente em quartos de hotéis. Trazemos, nesse ponto, a discussão sobre os não-lugares (Augé, 2008), que ambientam a trama. É 
importante levar em conta o caráter independete de realização do projeto transmídia e o orçamento enxuto para a produção. Nesse aspecto, talvez a escassez de cenas externas se deva à relativa facilidade de gravar em ambientas controlados (fechados).

Não se pode deixar de levar em consideração, também, as profissões globais que os protagonistas exercem e o caráter cosmopolita da obra. Ambientá-la em nãolugares, que são, conceitualmente, mais "assimiláveis", "conhecidos", é uma forma de criação de identificação com o público. Explorar as particularidades culturais de cada país por onde Latitudes passou exigiria, além de muito mais tempo, mais recursos. Desse modo, ela repousa no conforto de hotéis e restaurantes urbanos, com os quais os moradores de qualquer metrópole no mundo se relacionam e os quais reconhecem facilmente.

Também é importante notar que os personagens principais são viajantes, passam grande parte de suas vidas longe de casa. Nessa situação, contar com o que é familiar, que se traduz nos não-lugares, é muito importante. Por um lado, eles estão cada dia em uma cidade diferente, se deparando com o novo e desconhecido; por outro, podem repousar sobre reconhecimento de espaços globalizados, cujos códigos são facilmente assimilados e onde se sentem confortáveis. Desse modo, a utilização de não-lugares na narrativa se apresenta também como uma estratégia importante para a composição das personagens.

Após essa breve explicação dos caminhos percorridos para o desenvolvimento do trabalho, dos lugares e não-lugares por onde a narrativa passa, é hora de dar início à jornada. Dadas as coordenadas, vamos às Latitudes. 


\section{CAPÍTULO 1: TELEVISÃO EM TRANSFORMAÇÃO}

O presente capítulo trata das transformações ocorridas no cenário televisivo brasileiro, destacando sobretudo a forte relação existente entre a construção de uma matriz ficcional televisiva ancorada nos gêneros e formatos seriados, notadamente a telenovela. Para isso, recorre a uma aproximação cronológica dos avanços tecnológicos, sem, no entanto, ser essa sua finalidade. Busca-se sobretudo discutir como a televisão e a teleficção passam por transformações alterando significativamente suas formas de produção, fruição e distribuição. Por isso, entendemos que não há necessidade de retomar a exata cronologia dos fatos que marcaram tanto a invenção do dispositivo televisão quanto sua implantação em nosso País, tantas vezes discutidos e analisados (Wolton, 1996; Ortiz et al., 1996; Martín-Barbero, 2001; Mattelart e Mattelart, 1989). Embora, de acordo com a nossa construção argumentativa, possamos fazer referência a eles e discuti-los. Dessa maneira, consideramos que entender o cenário da televisão na atualidade e suas relações com a internet é basilar para o desenvolvimento deste trabalho e para a compreensão das múltiplas telas que encarnam a TV na contemporaneidade. Nesse cenário, observamos a ficção seriada como lugar privilegiado de análises sócioculturais no Brasil e na América Latina, devido à força que o gênero assume na região.

\subsection{TV: do contrato pedagógico à era multiplataformas}

A televisão, sendo influenciada diretamente pelas inovações tecnológicas, passa por diversas transformações conforme o desenvolvimento material ao qual é submetida. No intuito de entender essas transformações e "fases" pelas quais a TV se desenvolve, muitas terminologias e categorizações foram elaboradas. Uma que ganhou notoriedade nos estudos de Comunicação tem entre seus principais conceitos a Paleotelevisão e a Neotelevisão, desenvolvidos por Eco (1983). Eles tiveram, principalmente no final dos anos 1980, bastante popularidade no ambiente das ciências sociais (Scolari, 2014).

Baseada em um contrato pedagógico, a Paleotelevisão é relacionada a um projeto popular de educação (Scolari, 2014), no qual os profissionais da TV atuavam como propagadores de informações e saber, enquanto a audiência se reduzia a receptora desses conteúdos. Essa estrutura pressupõe uma hierarquia 
muito clara entre os detentores do conhecimento e aqueles aos quais esse conhecimento precisa ser transmitido. Para que esse estágio da televisão se desenvolvesse, também foi necessário durante muito tempo que se considerasse o público como massa homogênea, disponível para consumir mecanicamente a produção televisiva.

Uma característica marcante da Paleotelevisão é a segmentação da programação em repartições muito claras, que facilitem a assimilação do contrato de comunicação estabelecido (Eco, 1983). Além dos programas específicos para crianças, idosos, musicais, automobilísticos, esportivos, jornalísticos, entre outras temáticas bem definidas, a grade horária também era montada para aderir essa segmentação. Cada canal contava com horários e dias específicos para atender a determinado público: o dia e hora do entretenimento, do esporte ou do cinema, por exemplo. Esse modelo ainda permeia parte da estrutura da grade televisiva brasileira.

Recorrendo novamente a Eco (1983), a Neotelevisão opera de outra maneira, garantindo mais visibilidade à audiência no processo de consumo de conteúdos televisivos. De acordo com Casseti e Odin (1990), o novo modelo estabelecido altera não apenas o contrato de comunicação, mas também a maneira como fluxo e oferta se estruturam. De pedagógica, característica que marca a paleotelevisão, a TV passa a ser mais interativa e acessível. Não apenas o diálogo com as audiências é potencializado, como também passa a ocorrer de maneira mais organizada uma autorreferência entre os programas. Além das montagens mais rápidas, portanto, esse período é marcado pela expansão de game shows e programas de variedades que muitas vezes comentam os próprios conteúdos televisuais.

Percebemos, portanto, a plasticidade da televisão enquanto dispositivo tecnológico, que está submetida às transformações do seu tempo. Essas mudanças apontam para novos modelos de produção, distribuição e consumo que precisam ser visitados. Castells (2006) afirma que estamos em um mundo em transformação e que as tecnologias da informação e comunicação estão na crista dessas mudanças, mas não as determinam. Para ele, as tecnologias são formatadas de acordo com as necessidades, valores e interesses de seus usuários. Portanto, o autor categoriza a sociedade em rede como uma "estrutura operada por tecnologias de comunicação e informação fundamentadas na microelectrónica e em redes digitais de 
computadores" (CASTELLS, 2006, p. 20), que interliga as pessoas e se estabelece de acordo com nossas demandas, e não o contrário. Sobre esse fenômeno:

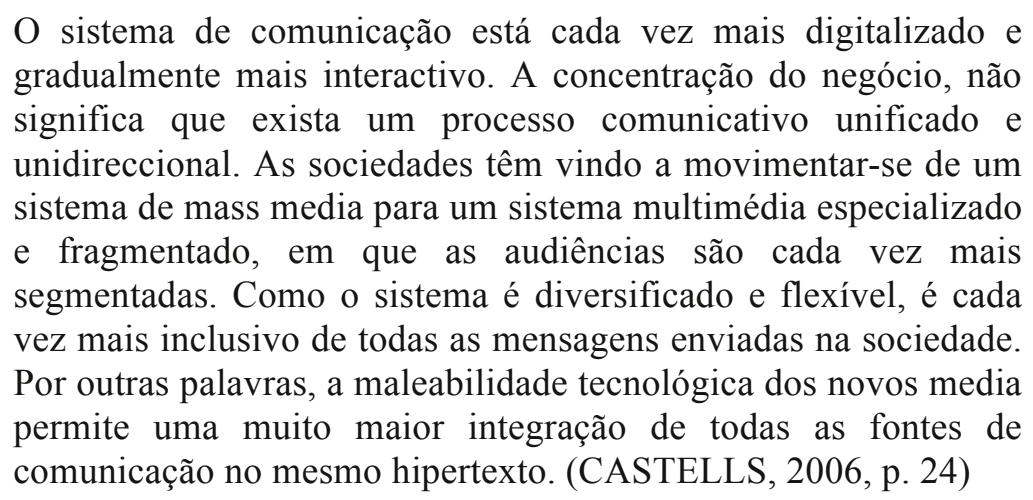

Percebe-se na contemporaneidade, portanto, a descentralização da TV no âmbito da produção e uma abertura maior à participação do telespectador, de modo que a audiência passa agora a ter mais espaço de atuação e interação com a programação televisiva. "Ela [a televisão] não é mais um espaço de formação, mas um espaço de convívio" (CASSETTI; ODIN, 1990, p. 11). Sobre o cenário dicotômico entre paleo/neotelevisão apresentado anteriormente, é importante marcar que é uma conceituação teórica útil para entender as mudanças na plataforma, que não pode ter suas condições sociais e técnicas isoladas. No entanto, a aproximação entre a TV e a internet gera um novo panorama que leva Scolari (2014, p. 41) a questionar: "E depois da neotelevisão, o que vem?”.

Essa pergunta de partida é respondida pelo próprio autor em seguida: ele define que a contemporaneidade é o momento da hipertelevisão. Rejeitando o termo pós-televisão - por considerar que não estamos em uma era depois da TV, mas em uma sequência do seu desenvolvimento -, Scolari apresenta a hipertelevisão compatível à ascensão da sociedade em rede (Castells, 2006). Nesse contexto, há a transformação da concepção massiva e generalista de TV para uma idéia mais fragmentada da audiência, diluída tanto em relação aos conteúdos quanto aos dispositivos.

Castells (2009) discute muito essa fragmentação midiática na sociedade em rede, que, a partir de relações de comunicação horizontais, principalmente devido à chegada e democratização da internet, empoderam e dão autonomia aos indivíduos. É possível perceber, portanto, que Castells coloca Comunicação e poder em uma esfera única, argumentando que o acesso aos meios de comunicação e informação dá ferramentas de resistência aos atores sociais. 
Pode-se dizer que, na atualidade, a audiência tem mais possibilidades de interferir diretamente na distribuição das narrativas televisuais, escolhendo não apenas uma gama infinitamente maior de conteúdos, mas também a hora e o lugar que deseja fruí-los.

Dada a crise do broadcasting, a fragmentação das audiências e o avanço de uma televisão reticular e colaborativa, marcada pelas experiências interativas de seus novos espectadores, propomos o conceito de hipertelevisão para definir essa nova configuração do meio televisivo. (SCOLARI, 2014, p. 44)

O que se pode apreender das novas experiências interativas é que o consumo da TV, em muitos casos, não mais necessita do aparelho de televisão. Este se tornou, na verdade, mais um dispositivo, entre vários outros, a partir do qual é possível fruir os conteúdos televisivos. A tendência mundial na produção de conteúdos televisivos é cada vez mais inclinada a considerar diversos suportes para veiculação, principalmente levando em conta as plataformas online.

Vemos na prática os grandes veículos de comunicação de massa cedendo espaço às práticas de intercomunicação individual (Castells, 2009), possíveis principalmente a partir da expansão de tecnologias de acesso à internet e às redes móveis. Percebe-se, portanto, maior autonomia dos indivíduos em seus processos comunicacionais e uma crescente resistência às distribuições massivas de conteúdos por parte das audiências.

Sob essa nova perspectiva, um dos aspectos mais característicos e contestados da TV tradicional é a grade horária. Frente a uma produção cada vez mais diluída e facilmente acessível, o público se mostra menos disponível a se submeter aos horários fixos da programação televisiva.

\footnotetext{
De acordo com Eliseo Verón, a televisão deixou de estar centrada em si mesma para deslocar-se rumo ao telespectador, agora, convertido em usuário. O sucesso dos reality shows ou a chegada das tecnologias que facilitam a interação com os conteúdos audiovisuais são alguns dos sintomas dessa mudança. Se acrescentarmos a isso a crise da programação (a televisão é dividida em diferentes telas, horários, situações de consumo e público) e a diferença entre oferta/demanda, paira uma sensação de que algo acabou (SCOLARI, 2014, p. 37).
}

Ao falar sobre o fim de algo, Scolari se refere à televisão como conhecemos. O autor deixa claro que não concorda com a profecia apocalíptica de alguns setores mais pessimistas dos estudos da Comunicação que defendem o fim da televisão enquanto fenômeno midiático sócio-cultural. O que o autor traz com o conceito 
hipertelevisão é precisamente uma nova fase da TV, talvez já não mais centrada no aparelho que tradicionalmente ocupa nossas salas de estar, mas agora muito mais no modelo de televisão enquanto arquivo, conforme será esclarecido mais adiante nesse trabalho. Scolari se atém menos à plataforma escolhida para a fruição e mais aos conteúdos transmitidos, que não deixarão de ser considerados simplesmente por não serem veiculados em um aparelho de televisão.

Por outro lado, Castells (2009) também não aponta para um ambiente de extinção de poder e hegemonia no campo da Comunicação. Na verdade, o que se percebe é um cenário de transferência de poder dos meios tradicionais às novas mídias, que também operam com lógicas próprias de dominação. A construção de oligopólios de comunicação nas redes, que determinam as construções ideológicas de sentido, representam novas possibilidades de hegemonia. No entanto, como o próprio autor afirma, onde há dominação, há resistência. O poder na sociedade em redes de Castells é multidimensional, conceito chave para a compreensão da autocomunicação (Castells, 2009), uma maneira de produzir, acessar e compartilhar conteúdos sem mediação. Esse modelo de comunicação surge em oposição à indústria de mídia que conhecemos e se baseia na comunicação por meio das redes sociais.

Não significa, no entanto, a extinção da mídia hegemônica, mas sua adaptação à realidade reticular da sociedade em rede. Cada vez mais, grandes mercados nacionais e globais de mídia precisam se inserir na realidade das redes sociais e individualizar suas relações com os públicos. Percebemos, portanto, que Scolari traz contribuições mais relacionadas ao desenvolvimento tecnológico dos meios, enquanto Castells coloca o tempo como catalisador das mudanças sociais no campo da Comunicação. Baseados nas leituras e articulações entre os dois autores, construímos um quadro de apresentação de suas principais contribuições para a organização da presente pesquisa. 


\begin{tabular}{|c|c|}
\hline Scolari & Castells \\
\hline $\begin{array}{l}\text { Identifica que as transformações ocorridas na } \\
\text { sociedade em rede ocorrem após a } \\
\text { transformação da sociedade digital. Ou seja, } \\
\text { atribui ao avanço das tecnologias grande parte } \\
\text { do impulso necessário para o estabelecimento } \\
\text { de transformações sociais. É a partir dele que } \\
\text { se entende o caráter reticular e } \\
\text { multiplataforma da televisão, que não irá } \\
\text { acabar, mas se submeterá às mudanças } \\
\text { estabelecidas pelo contexto técnico. }\end{array}$ & $\begin{array}{l}\text { A sociedade em redes dissolve fronteiras de } \\
\text { espaço e tempo, colaborando para a } \\
\text { simultaneidade dos fatos enquanto ocorrem. } \\
\text { Representa uma transitoriedade estrutural de } \\
\text { poder, que tem potencialidade para, } \\
\text { gradativamente, ser transferido de grandes } \\
\text { mercados de mídia para os indivíduos. Não } \\
\text { ignora, no entanto, que as relações } \\
\text { mercadológicas online criam suas próprias } \\
\text { lógicas de hegemonia e dominação. }\end{array}$ \\
\hline
\end{tabular}

Dada essa contextualização, introduzimos Latitudes, uma obra que inova em sua produção e distribuição no mercado de audiovisual ficcional brasileiro. Ela se configura como nosso objeto de análise e será profundamente apresentada no terceiro capítulo desse trabalho. Levando em conta as características descritas anteriormente, se percebe a obra inserida na realidade da hipertelevisão e da autocomunicação, disponibilizando seus conteúdos diluídos em várias plataformas, em um contexto produtivo independente da grande indústria de mídia ${ }^{2}$ e permitindo a fruição de vários deles à vontade e possibilidade do espectador.

Antes de entrarmos na discussão da serialização como componente da TV brasileira na contemporaneidade, no entanto, é preciso compreender o contexto de instalação da mídia no país. De maneira geral, foi uma implantação que seguiu o modelo historicamente estabelecido de concentração midiática instaurado desde o nascimento da imprensa no país, mais precisamente, em termos de operação, organização e financiamento de televisão, adotava o modelo comercial norteamericano - ou seja com relações íntimas entre a imprensa e o poder econômico.

(...) jornais que refletiam interesse de alguma autoridade ou algum grupo, comprovando que a imprensa sempre se desenvolveu em estreita ligação com a atividade política, acompanhando a cisão existente entre direita conservadora (representada pelos jornais áulicos ou imprensa absolutista), direita liberal (que pregava a monarquia constitucional) e

\footnotetext{
${ }^{2}$ Apesar de distribuído no YouTube, no canal pago TNT e no circuito comercial de cinemas, o projeto transmídia Latitudes foi produzido de maneira independente, com captação de recursos a partir de inserções roteirizadas de marcas parceiras e sem vinculação a grandes produtoras ou emissoras de televisão. Mais aspectos da realização de Latitudes serão trazidos ao longo do desenvolvimento do trabalho.
} 
esquerda liberal (representada pelos pasquins). (RIZZOTTO, 2012, p. 115)

Ligada aos grupos que sempre controlaram a mídia brasileira desde que ela existe (principalmente as plataformas impressas), a televisão surge, se populariza e passa a ocupar lugar fundamental na difusão da ideologia dominante. Assim como os veículos impressos anteriormente só se desenvolviam com apadrinhamentos oficiais, as emissoras de televisão em sua origem só existiram por conta de conchavos políticos e conveniências de grupos econômicos privilegiados.

Infelizmente, uma situação não muito diferente se mantém até os dias de hoje. Apesar da existência de um marco regulatório desde 1962 e de leis específicas que deveriam impedir essa situação, muitas concessões públicas de transmissão televisiva estão nas mãos de políticos exercendo cargos eletivos, contrariando a proibição prevista na Constituição brasileira ${ }^{3}$. Além disso, poucos grupos econômicos controlam a difusão de informações por meio de emissoras regionais menores, que se filiam e aumentam o poder de grandes oligopólios midiáticos. $\mathrm{O}$ gráfico abaixo foi retirado do site Donos da Mídia e ilustra bem essa situação:

Gráfico 1: Ranking das redes de TV

\section{Ranking das redes de TV}

\begin{tabular}{|lr|} 
Rede & Veículos \\
\hline Globo & 340 \\
\hline SBT & 195 \\
\hline Band & 166 \\
\hline Record & 142 \\
\hline EBC & 95 \\
\hline Rede TV! & 84 \\
\hline
\end{tabular}

Fonte: www.donosdamidia.com.br

Pode-se ver, a partir do gráfico, as cinco maiores redes comerciais do país (Globo, SBT (Sistema Brasilero de Televisão), Band (Rede Bandeirantes), Record e

\footnotetext{
${ }^{3} \mathrm{O}$ artigo 54 da Constituição Federal de 1988 é claro ao proibir os parlamentares de serem detentores de concessionárias de serviços públicos, como as radiodifusoras e emissoras de televisão.
} 
Rede TV!) - também constando na lista a pública EBC (Empresa Brasil de Comunicação). Os veículos considerados na coluna à direita se referem às emissoras de TV geradoras ou retransmissoras do sinal da "cabeça-de-rede", que é o conglomerado nacional. Essa conformação da mídia brasileira respeita parâmetros legais, mas sem dúvida atenta contra a noção do pluralismo de fontes de informação que sustenta a concepção moderna de democracia.

Outro ponto fundamental para se pensar a formação do cenário midiático televisivo nacional refere-se às concessões públicas de difusão de informação controladas por políticos eleitos e em exercício de seus cargos. Conhecida como “coronelismo eletrônico", a prática é não só um atraso para a democratização da comunicação, como também privilegia os donos de veículos de mídia nos processos eleitorais.

Gráfico 2: Emissoras controladas por parlamentares

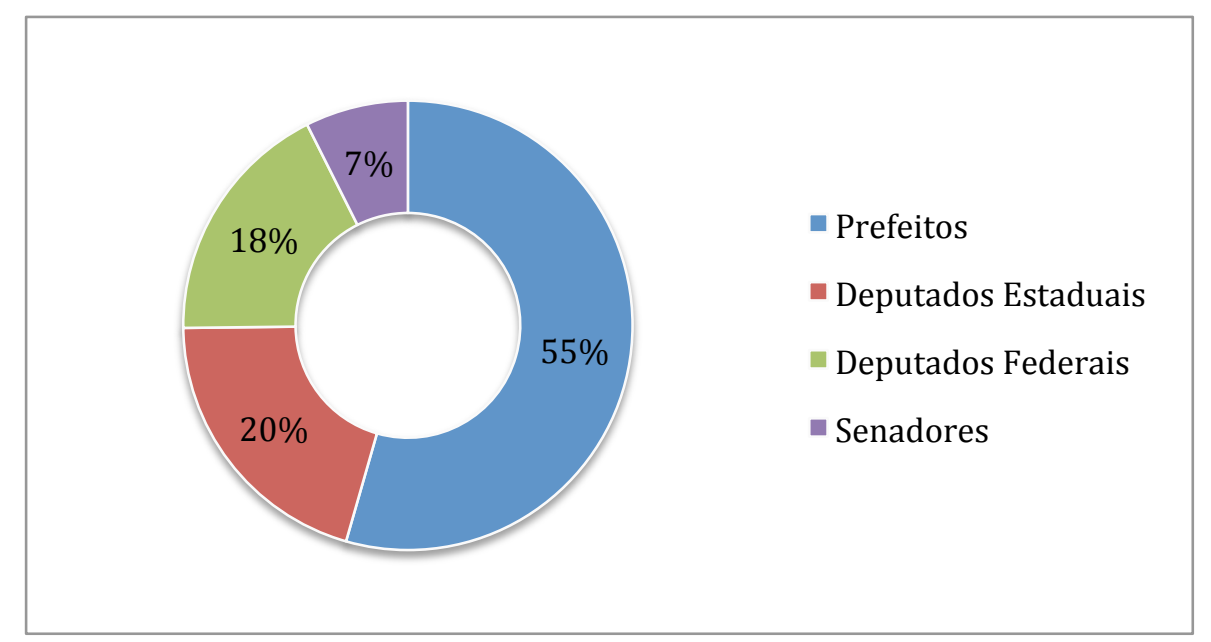

Fonte: www.donosdamidia.com.br

A partir de um levantamento realizado pelo Projeto Donos da Midia ${ }^{4}$, foram cruzados dados da Anatel (Agência Nacional de Telecomunicações) com a lista de prefeitos, governadores, deputados e senadores brasileiros. A pesquisa se refere aos políticos com mandatos até janeiro de 2009 e aponta que, até então, 271 deles eram sócios ou diretores de 324 veículos de comunicação nacionais.

Traçar esse panorama de formação da conjuntura midiática brasileira é

\footnotetext{
${ }^{4}$ Projeto sem fins lucrativos que reúne dados disponibilizados no Mercado para traçar um panorama detalhado acerca da concentração de mídia experienciada no Brasil. As informações são divulgadas no site http://donosdamidia.com.br/.
} 
fundamental para as próximas etapas do trabalho, quando falaremos sobre medidas de democratização da produção audiovisual e novos formatos de distribuição e consumo de conteúdos audiovisuais. É importante pensar também nesse formato como uma referência da América Latina, que constituiu suas empresas de comunicação com base em interesses políticos e econômicos, em um ambiente no qual o Brasil está profundamente inserido.

\subsection{A serialização: o poder da teleficção na constituição da TV brasileira}

Como dissemos no início do capítulo, esse trabalho não pretende fazer análises sobre as telenovelas brasileiras. No entanto, para compreensão das nossas produções culturais, é importante considerá-las, visto que são o produto audiovisual de maior sucesso no país. A telenovela se configura, portanto, como elementochave para o crescimento e conformação do cenário de ficções seriadas nacionais, conforme é abordado nesse tópico.

Quando se fala da televisão no Brasil, desde seu surgimento até a atualidade, é impossível não incluir a ficção seriada nessa linha do tempo principalmente a telenovela. Após o início oficial das transmissões em 1950, a primeira telenovela exibida na TV brasileira foi Sua vida me pertence, dirigida por

Walter Forster, ainda em fevereiro de 1951. O gênero está, portanto, ligado à cultura televisiva nacional desde a sua gênese.

De lá para cá, a telenovela se consolidou como principal produto da indústria televisiva nacional e um dos principais elementos da cultura brasileira. Devido à importância e aceitação do formato, o Brasil surpreendeu e superou um prognóstico feito genericamente para os países latino-americanos no que toca a sua dependência cultural de conteúdos televisivos do norte econômico global (Lopes, 2003). Desde a implatanção da televisão no Brasil, ao longo das décadas, a produção de telenovelas cresceu e se consolidou como uma das principais formas de entretenimento da população brasileira, o que, por sua vez, estimulou e orientou a produção nacional tornando-a artigo de exportação para o mundo.

Essa força garantida pelo gênero permitiu ao Brasil, ainda durante a década de 1970, uma capacidade televisiva nacional (Lopes, 2003). De acordo com a TV 
Globo $^{5}$, por exemplo, a telenovela Avenida Brasil, dirigida por João Emanuel Carneiro e exibida em 2012, teve seus direitos de exibição adquiridos por 106 países e foi dublada em 14 idiomas diferentes. Dessa forma,

(...) é possível afirmar que a telenovela no Brasil conquistou reconhecimento público como produto artistico e cultural e ganhou visibilidade como agente central do debate sobre a cultura brasileira e a identidade do país. Ela também pode ser considerada um dos fenômenos mais representativos da modernidade brasileira, por combinar o arcaico e o moderno, por fundir dispositivos narrativos anacrônicos e imaginários modernos e por ter a sua história fortemente marcada pela dialética nacionalização-massmediação. (LOPES, 2003, p. 17)

Para Lopes (2003), a telenovela no Brasil se estabeleceu como uma narrativa da nação (Lopes, 2003), à medida que representa as contradições existentes no país, referentes à desigualdade social, às distinções entre a vida no campo e na cidade, no interior e no litoral e toda a diversidade presente em nosso território de dimensões continentais. De acordo com Borelli (2001), a telenovela assume importância no contexto brasileiro a ponto de se constituir como local privilegiado para a realização de análises da cultura do país. O gênero, portanto, tece um repertório comum entre os brasis que cabem em uma só nação, que, a partir da intensa penetração possibilitada por meio da televisão, permite que os diferentes se reconheçam.

A influência da ficção no Brasil é tão forte que determina, desde a década de 1970 - em uma criação que se deve muito ao investimento da Globo na "dobradinha" ficção / telejornal / ficção - o prime time (ou horário nobre) da televisão, faixa da programação em que são vendidos espaços mais caros para a veiculação de anúncios. Esse horário é compreendido, na emissora em questão, por três telenovelas diárias um telejornal local e outro nacional. Mais recentemente, o horário nobre, originalmente estendido entre as 18 horas e as 22 horas, passa a abranger também a faixa das $23 \mathrm{~h}$, quando sazonalmente é exibida pela Globo uma ficção: telenovela, minissérie ou série, constituindo-se como um horário em que há certa possibilidade de experimentação em termos de formato. Esse recurso de criação de hábitos de consumo na audiência se estabelece desde a implantação da televisão no país e permanece até hoje. Porém, ele vem sendo contestado por novos

\footnotetext{
${ }^{5}$ Fonte: site da Rede Globo. Disponível em: http://redeglobo.globo.com/novelas/noticia/2013/07/avenida-brasil-e-novela-mais-vendida-daglobo-no-exterior.html (acesso em 24 de fevereiro de 2016).
} 
sistemas de produção, distribuição e consumo dos conteúdos possíveis a partir da popularização do streaming, mas trataremos disso em outro momento.

Por ora, é importante salientar que, historicamente, o formato de produção audiovisual para a televisão se baseia em uma estrutura cujos conteúdos são distribuídos unilateralmente, por meio de uma grade de programação linear, com escassas possibilidades de interação com as audiências. Nessa lógica, um dos grandes interesses das emissoras de televisão é cativar e "educar" o público para que este saiba os horários e conteúdos da programação. Desse modo, cria-se uma cultura para assistir a televisão, que é linear e de fluxo e segue uma dinâmica temporal rígida no cotidiano, organizando inclusive os horários para outras atividades sociais.

Dentro do modelo altamente concentrado e comercial da televisão brasileira, a serialização serve como esteio de sua programação. A partir dessa formatação, é possível garantir uma produção contínua que, uma vez testada e aprovada, agrada a audiência, o que permite a sobrevivência econômica e competitividade da mídia. Além disso, pode-se compreender a serialização de uma maneira bastante ampla, como elemento constituinte do cotidiano, ele próprio marcado pela fragmentação e serialização características da programação televisiva (MACHADO, 2000). Em outro sentido, pode-se compreender a serialização para além da repetição e do conteúdo raso, como faz Eco (1994); no intento de conseguir, além de estabelecer fruições episódicas simples baseadas em leituras de primeiro nível, trazer leituras mais complexas de segundo nível (Eco, 1994), que estimulam o espectador acostumado à linguagem televisiva a interpretações a partir da instância intertextual para compreender os conteúdos apresentados.

Apoiadas em Eco (1994), Motter e Mungioli (2006) lembram que o "ineditismo estético" é uma demanda da Modernidade, visto que no período clássico grego, o valor da obra estética se apoiava na repetição de um modelo dito perfeito. Desse modo, a dificuldade em encarar obras ficcionais televisivas seriadas como dignas de análises no campo científico nos dias atuais repousa na sua apreensão, por vezes, como um gênero "menor" ou artisticamente inferior. Ainda sobre isso, complementam:

A grande audiência devotada aos programas seriados na televisão e mesmo a alguns filmes de cinema (que são apresentados em episódios ou que permitem uma continuidade devido ao sucesso de público e de crítica) vem demonstrar que o público recebe bem 
a repetição e, às vezes, até espera por ela. (MOTTER; MUNGIOLI, 2006, p. 7)

O prazer na fruição de produções seriadas, portanto, se concentra no presente, porém é irremediavelmente ligado às experiências passadas de contato com obras estéticas. Conhecer o passado, o "já visto" ou "já sentido" se vincula ao prazer no momento da fruição, de maneira que "entram em jogo nesse momento, a memória coletiva e a memória individual que se articulam num eixo composto também pela memória audiovisual, num processo dialético em que constroem a identidade individual e a identidade coletiva" (MOTTER; MUNGIOLI, 2006, p. 8). Além de tudo isso, apostar constantemente em novos formatos seria por demais dispendioso e arriscado, à medida que o seriado, a partir do momento em que é veiculado, reconhecido e assimilado pelo público, já representa certa segurança em níveis de audiência e aceitação.

Um programa que "não agrada" representa um grande prejuízo à emissora, $\log o$, a produção televisiva acaba reciclando a maioria de seus formatos, mantendo a estrutura e modificando itens superficiais, ou ainda combinando formatos já testados e aprovados pela audiência. Essa repetição é outro aspecto da arte televisiva que costuma ser criticado. Mais uma vez, é como se as catedrais fossem criticadas apenas porque seus criadores precisaram submeter sua arte aos limites impostos pelo terreno, pela verba e pelos interesses ideológicos de seus patrocinadores. Além disso, a repetição também pode ser usada para alcançar grandes efeitos estéticos. (CANNITO, 2010, p. 58)

A partir dessa estrutura, foi possível que a narrativa seriada se popularizasse na televisão, apesar de não encontrar aí a sua origem. Arlindo Machado (2000) afirma que a produção seriada audiovisual ocorre desde 1913, por meio dos nickelodeons, filmetes voltados para o público de baixo poder aquisitivo nos cinturões industriais de cidades européias e estadunidenses, principalmente. As formas epistolares de literatura, como cartas e sermões, também já evidenciavam a narrativa seriada, além dos folhetins datados do século XIX. Elas podem ser descritas, portanto, como:

\begin{abstract}
A narrativa seriada caracteriza-se por ser uma narrativa dividida em episódios ou capítulos, que podem ser exibidos em dias e horários diferentes. Um episódio deve contar sua história, inserirse no conjunto, respeitar as características lançadas pelo programa no seu total. (PALLOTTINI, 1998 p.31)
\end{abstract}

Na televisão, em geral, considera-se que existem três tipos de classificação 
para a narrativa seriada: a primeira conta com uma ou mais tramas que vão se desenvolvendo de acordo com a sucessão de capítulos; a segunda conta com personagens fixos, mas cada capítulo (ou episódio, em nosso entender) começa e encerra uma narrativa própria; e a última conta com personagens e histórias diferenciados, mas mantém uma linha temática comum entre os capítulos (Machado, 2000).

As três classificações elaboradas por Machado, entretanto, nem sempre ocorrem isoladamente. Não são estanques, mas permitem hibridismos que originam novos formatos seriais. Em um ambiente multiplataforma, essa característica é potencializada, conforme trataremos adiante. A partir das combinações possíveis e expandidas com as inovações técnicas da contemporaneidade, são estabelecidas novas estruturas diferentes do que estamos habituados.

A riqueza da serialização televisual está, portanto, em fazer dos processos de fragmentação e embaralhamento da narrativa uma busca de modelos de organização que sejam não apenas mais complexos, mas também menos previsíveis e mais abertos ao papel ordenador do acaso. (MACHADO, 2000 p.97)

Desde meados da década de 1990, com a gradativa popularização da internet, a grade linear que pautava historicamente a programação das grandes emissoras de televisão foi sendo alterada. A princípio, com a internet discada, o diálogo possibilitado era instável, lento e os formatos potenciais ainda não haviam sido devidamente experimentados. A produção e consumo de audiovisuais eram inicialmente insipientes neste meio.

A entrada da banda larga no mercado trouxe possibilidades de mudanças no cenário. $\mathrm{O}$ modelo de entretenimento proposto pela mídia hegemônica televisiva passou a ser revisto e novas formas de consumo audiovisual surgiram a partir da experiência online. A própria narrativa seriada ficcional, representada principalmente pela telenovela, carro-chefe da produção cultural para televisão no Brasil, precisou rever seus modelos de produção e consumo a partir da inserção das mídias digitais como alternativa de comunicação e entretenimento e mesmo assim enfrenta, a exemplo do que ocorre em outro países, cada dia mais fortemente a concorrência via internet ${ }^{6}$, inclusive de gênero ficcional

\footnotetext{
${ }^{6}$ De acordo com pesquisa realizada em parceria entre o Interactive Advertising Bureau Brasil (IAB Brasil) e a estadunidense comScore, especialista em análises de internet, $82 \%$ dos brasileiros consideram a internet o principal meio de informação e entretenimento em seu cotidiano. Divulgado
} 
$\mathrm{Na}$ atualidade, é possível ofertar, por exemplo, os produtos mostrados/ consumidos nas telenovelas para venda online, além da exibição de compactos de capítulos das ficções ou mesmo disponibilização das tramas inteiras para download em portais e hotsites. Além disso, hoje são comuns as extensões narrativas de telenovelas e séries por meio da criação de páginas virtuais que se relacionam com a diegese e criam novas perspectivas de interação com o público. Por vezes, inclusive, as tramas televisuais se expandem em webséries destinadas exclusivamente para a fruição no website. Essas mudanças precisam ser analisadas, uma vez que:

Embora já se tenha avançado bastante com relação à elaboração de uma linguagem apropriada e exclusiva para discutir a televisão acreditamos que essa tarefa continuará em construção devido a pelo menos duas razões. A primeira delas refere-se ao fato de que a linguagem televisual, como qualquer outra linguagem, é dinâmica e se situa dentro de um universo cultural do qual se alimenta e para o qual é alimento. Portanto, está sujeita a interrelações com outras linguagens das quais, em maior ou menor medida, sofrerá influências ao mesmo tempo em que as influenciará. (MUNGIOLI, 2006 p. 31)

A televisão, portanto, não é absoluta e imutável, mas está sujeita a perturbações e alterações socioculturais e tecnológicas. Nada mais natural, então, que ela se transforme conforme incorpora inovações tecnológicas que influenciam seus modos de produção, distribuição e consumo. Ao mesmo tempo, a mídia orienta produções de sentido que se constroem sobre essas novas dinâmicas quando se pensa em termos de dispositivos (Maingueneau, 2008). E entre esses produtos, destacam-se no Brasil aqueles formatados pela estrutura serializada, sejam eles ficcionais ou não.

no primeiro semestre de 2016, o estudo também aponta que $40 \%$ dos 2.075 entrevistados gastam ao menos duas horas de seus dias navegando nas redes, enquanto apenas $25 \%$ passam o mesmo período assistindo TV. Mais informações sobre a pesquisa podem ser acessadas pelo link: http://www.gilbertogodoy.com.br/ler-post/audiencia-da-internet-ja-supera-a-da-tv-no-brasil.

Interessado nesse mercado em expansão, o Kantar IBOPE Media já criou algumas metodologias de aferição das audiêcias online. Apesar de ainda centralizar suas métricas na televisão, merece destaque o dashboard, plataforma da empresa criada para medir o engajamento dos telespectadores no ambiente digital. A iniciativa revela uma grande transformação que apoxima as fronteiras online e offline, de maneira que os projetos televisivos precisam crescentemente convergir também para a internet se pretendem alcançar certas (e cada vez maiores) faixas de audiência. 


\section{CAPÍTULO 2: METODOLOGIA E PROCEDIMENTOS METODOLÓGICOS}

O presente trabalho analisou as estratégias de transmidiação desenvolvidas no âmbito da produção do Projeto Transmídia Latitudes, veiculado no YouTube, televisão $\left(\mathrm{TNT}^{7}\right)$ e cinema. Embasado na abordagem dos estudos de linguagem de Bakhtin e de produção de sentido, o trabalho procurou, por meio da apreensão da materialidade e concretude do discurso, identificar as estratégias de transmidiação desenvolvidas na etapa de produção da obra, inserindo-as no contexto mais amplo da cultura da convergência (Jenkins 2008), que marca de maneira indelével a comunicação e a experiência estética dela decorrente na contemporaneidade.

Em particular, o estudo proposto se dedica à análise das significativas mudanças que vêm ocorrendo, de acordo com Ryan (2005), Jenkins (2008), Castells (2006), Scolari (2013) Lopes e Mungioli (2011), nas condições de produção, distribuição e consumo cultural, cuja matriz produtiva associa antigas e novas mídias para a construção de narrativas.

Nesse contexto, marcado pelos novos meios de comunicação e pela transmidiação, a proposta de pesquisa ora apresentada se caracteriza como um estudo de caso que pretende realizar uma exploração em profundidade do Projeto Transmídia Latitudes ${ }^{8}$, considerando seus elementos constitutivos como integrantes de um conjunto de estratégias adotadas pelos produtores para a constituição de uma narrativa que se desdobra em três plataformas (televisão, internet e cinema) e diferentes formatos (série de televisão, websérie e filme). Para isso, consideramos com Bakhtin (2003, p. 177) que, na materialidade da obra estética, apresentam-se tensões entre os três elementos que a compõem: "o conteúdo, o material, a forma". O estudo empreendido também leva em conta as contribuições de Jenkins (2008, 2012), Fechine (2013), com a finalidade de identificar e categorizar as estratégias de transmidiação estabelecidas no âmbito da produção e distribuição de Latitudes.

O objetivo teórico da pesquisa foi identificar e discutir as estratégias de transmidiação na ficção audiovisual brasileira, enfocando, por meio da técnica de

\footnotetext{
${ }^{7}$ Como explicamos anteriormente, o Turner Network Television (ou apenas TNT) é um canal pago de televisão especializado em filmes e séries, responsável pela exibição de Latitudes na TV.

${ }^{8}$ Latitudes é uma narrativa ficcional apresentada em três plataformas diferentes: YouTube, televisão e cinema. A obra estreou suas versões seriadas na internet e televisão no segundo semestre de 2013 e foi distribuída em formato de filme de longa metragem no começo de 2014. A produção é assinada pelo diretor Felipe Braga, da produtora brasileira Los Bragas.
} 
pesquisa de estudo de caso, o Projeto Transmídia Latitudes, buscando estabelecer definições e categorias a partir do polo da produção. Assim, procuramos trazer elementos para a expansão teórica do debate sobre a transmidiação enquanto tendência do campo da Comunicação no Brasil O objetivo empírico do projeto se delineou a partir da análise do corpus e identificação de características que revelassem as estratégias de transmidiação adotadas pela produção na distribuição e veiculação da ficção Latitudes, bem como os recursos discursivos adotados tendo em vista a produção de sentidos envolvida nesse processo. Dito de outra forma, o estudo pretendeu discutir e analisar quais elementos caracterizavam uma narrativa transmídia concebida na esfera da produção e quais os seus desdobramentos. Entre os objetivos específicos do trabalho, destacamos:

1) Identificar qual plataforma se apresenta como o locus da nave-mãe da narrativa (Jenkins, 2008) a partir da análise da diegese e seus desdobramentos em diferentes plataformas;

2) Analisar os discursos componentes da obra como características de um gênero próprio (e novo), com modelos próprios (e novos) de produção, distribuição, inserção mercadológica e consumo;

3) Identificar e categorizar estratégias transmídia utilizadas na etapa da produção da obra Latitudes;

4) Identificar elementos histórico-culturais que suscitem entendimentos acerca dos processos de produção audiovisual no contexto brasileiro;

5) Analisar as particularidades de distribuição e formato estabelecidas na obra entre as três plataformas consideradas: YouTube, Televisão e Cinema;

6) Identificar elementos que caracterizem estéticas próprias da produção, distribuição e consumo de audiovisual para a internet.

\subsection{Procedimentos}

O trabalho considera a Comunicação sob uma perspectiva multidisciplinar, de maneira que várias áreas da ciência confluam para a análise de um objeto comum, garantindo a pluralidade e riqueza de perspectivas e visões. Afinal, como afirmam Laville e Dionne (1999), a delimitação em disciplinas isoladas pode ser um obstáculo para a compreensão do problema em sua plenitude. 
Dentro dessa realidade, escolheu-se a utilização do estudo de caso como técnica de pesquisa, que possibilita o aprofundamento necessário em determinado objeto para que analisemos suas particularidades e universalidades. A princípio, o estudo de caso visa compreender e explicar o único caso específico; pode, no entanto, ser aplicado a outros objetos quando o caso analisado for considerado típico de um conjunto mais geral, do qual se torna representante. No caso específico de Latitudes, é importante que esse tipo de análise seja feita, por se tratar de um objeto muito particular, que articula elementos da internet, da televisão e do cinema, que demandam olhares e análises que não são costumeiramente cruzados no campo científico.

Também foi realizado um levantamento de fontes documentais, principalmente em arquivos digitais. Para a pesquisa, são considerados: (1) os oito webisódios que compõem a websérie disponibilizada no YouTube; (2) os oito episódios televisionados e veiculados pela TNT e (3) o filme que esteve em cartaz nos cinemas. Os webisódios estão facilmente acessíveis pelo canal de Latitudes no YouTube $^{9}$ e os episódios televisionados e o longa metragem foram gravados pelo pesquisador, por meio do serviço de uma operadora de TV paga. Além disso, o filme Latitudes está disponível no provedor de conteúdos on demand Netflix, o que também possibilita facilmente o acesso à obra para análise.

Para a etapa de análise do trabalho, contar com a digitalização da televisão em curso no Brasil foi fundamental. A partir das novas perspectivas de oferta on demand da programação, foi possível acesso quase irrestrito à obra, de maneira que não ficamos presos aos horários e dias de exibição vigentes na lógica broadcast. No trânsito da obra da internet para a televisão e para o cinema, observamos que são feitas mudanças na narrativa que interferem no ritmo da trama e trazem novos conteúdos para a fruição das audiências. Na plataforma televisiva, as cenas da trama são intercaladas com extras da produção, construindo uma metanarrativa que apresenta Latitudes como uma obra ficcional e revela os bastidores e detalhes de sua realização. A partir da análise de todos os episódios televisionados e dos episódios da websérie, propusemos o estabelecimento de categorias que definem as inserções de conteúdos que não estão originalmente disponíveis no YouTube.

Tais categorias foram criadas de acordo com a demanda para esta pesquisa e

\footnotetext{
${ }^{9}$ Disponível em: https://www.youtube.com/user/Latitudesfilme
} 
representam uma abordagem quantitativa ao estudo, buscando definir aspectos mais estruturais à análise do projeto.

A partir do momento em que a pesquisa centra-se em um problema especifico, é em virtude desse problema específico que o pesquisador escolherá o procedimento mais apto, segundo ele, para chegar à compreensão visada. Poderá ser um procedimento quantitativo, qualitativo, ou uma mistura de ambos. $\mathrm{O}$ essencial permanecerá: que a escolha da abordagem esteja a serviço do objeto de pesquisa, e não o contrário, com o objetivo de daí tirar, o melhor possível, os saberes desejados. (LAVILLE; DIONNE, p. 43, 1999)

$\mathrm{Na}$ sequência, discutimos o papel fundamental desenvolvido pelas plataformas sociais, nomeadamente o YouTube, no surgimento de novos modelos de produção, distribuição e consumo de ficção seriada. Tais discussões apoiam-se principalmente em Massarolo e Mesquita (2014) e Massarolo e Alvarenga (2010) que esclarecem modelos de negócios que distinguem o mercado televisual a partir do streaming.

Em um passeio mais aprofundado pela diegese de Latitudes, adotamos o recurso de elaboração de sinopses de cada um dos episódios da obra. Desse modo, é possível ter uma visão detalhada da narrativa, que possibilita uma análise mais rica nas próximas etapas de desenvolvimento do trabalho. Além disso, essa explicação detalhada visa atender o leitor que não teve contato com o projeto transmídia nas plataformas onde ele foi veiculado.

Para fazer uma análise das estratégias de transmidiação adotadas em Latitudes, lançamos mão de categorias estabelecidas por Fechine (2013), cuja síntese concentra os procedimentos de Propagação e Expansão. $\mathrm{Na}$ operacionalização dos conceitos, optamos por dividir o corpus de acordo com as plataformas nas quais foi veiculada. Nesse sentido, não elaboramos as estratégias de maneira geral, mas de forma particularizada em cada uma das operações de transposição estabelecidas. Tal procedimento torna possível identificar a narrativa que se constitui como nave-mãe (Jenkins, 2008) e, a partir dela, observar como Latitudes se espalha para as demais mídias.

Devido ao caráter multiplataforma do objeto empírico, utilizamos também para a análise o conceito de Reassistibilidade (Mittel, 2011), que nos coloca em contato com a replicação do conteúdo narrativo de Latitudes entre as mídas que circula. Associado às noções de intertextualidade de Fiske (1987), o termo trará luz 
ao debate sobre as estratégias de transmidiação em conjunto com as categorias estabelecidas por Fechine.

Por fim, discutimos os achados da pesquisa a partir do conceito dos nãolugares (AUGÉ, 2008), que revelam muito sobre uma estratégia de diálogo com o target proposto. Desse modo, pretendemos cercar o objeto de estudos, para que as estratégias de transmidiação no âmbito da produção fossem desveladas e, mais que isso, nos trouxessem elementos para traçar aspectos que se apresentem como tendência de realização, distribuição e consumo de projetos de ficção transmidiáticos. Para dar inicío a essa aventura, cabe, no capítulo seguinte, fazer uma apresentação detalhada do objeto empírico, revelar Latitudes. 


\section{CAPÍTULO 3: LOCALIZANDO LATITUDES}

Latitudes se apresenta como um projeto que leva conteúdos ficcionais inéditos para a intenet - assim como aconteceu no mercado fonográfico anteriormente, com arquivos digitais determinando profundas mudanças em seus modelos de produção, consumo e distribuição. A obra foi disponibilizada em oito webisódios no YouTube, que foram lançados (em 2013) concomitantemente à exibição pelo canal TNT, no seguinte: às quartas-feiras o webisódio era disponibilizado no YouTube e na segunda-feira seguinte estreava no canal pago TNT. Nos cinemas, o filme Latitudes estreou somente em fevereiro de 2014. Pelo YouTube, é possível acompanhar o desenvolvimento da trama puramente ficcional, ficando a cargo da televisão trazer elementos extras. Desse modo, Latitudes se configura como uma narrativa transmídia em três formatos: websérie (com oito webisódios), série de televisão (com oito episódios) e um longa metragem.

Um dos fatores que garantem legitimidade à obra frente ao público e à crítica é a equipe envolvida - renomada e com trajetórias sólidas em plataformas tradicionais, nomeadamente, na televisão e no cinema. De acordo com o diretor Felipe Braga, “desde o início decidimos que o Latitudes teria um alto padrão de produção. Se não tivéssemos um elenco que competisse com a televisão ou com o cinema e uma narrativa mais sofisticada, ele poderia cair numa vala comum de série de webtelevisão. O projeto só daria certo se tivesse um padrão de produção que colocasse em primeiro plano o conteúdo, e não o projeto transmídia em si" ${ }^{\text {10 }}$.

Idealizador, roteirista e diretor do projeto, o diretor carioca possui experiência em produções de sucesso na televisão, como Mandrake, Destino SP e Destino Salvador, da HBO América Latina. Para o cinema, escreveu o roteiro do longa metragem Cabeça a Prêmio, que obteve premiações em diversos festivais nacionais. Seu primeiro trabalho como diretor ocorreu no documentário B1 Tenório em Pequim, que conta a história de um judoca paraolímpico com deficiência visual total competindo nas Olimpíadas da China.

Indicado duas vezes ao Emmy (uma com Latitudes e outra com a série documental Neymar Jr's Life Outside the Fields), Felipe tem doutorado pela PUCRio, Brasil / Paris III, Sorbonne Nouvelle. Mais recentemente, Braga esteve

\footnotetext{
${ }^{10}$ Fonte: Panorama Audiovisual. Disponível em: http://www.panoramaaudiovisual.com.br/2013-10projeto-transmidia-latitudes-na-10a-conferencia-panorama-audiovisual-9597 (acesso em 2 de março de 2016).
} 
envolvido na direção do documental cinematográfico Tracks: Dance, da HBO, filmado no Royal Ballet, em Londres. Também é roteirista do filme Marighella, que está em processo de produção e será dirigido por Wagner Moura.

Além da carreira de Felipe Braga, Latitudes se alicerça também sobre o nome reconhecido internacionalmente de Alice Braga. A atriz paulistana já estrelou inúmeros filmes brasileiros, como Cidade de Deus, Cidade Baixa, O Cheiro do Ralo, entre outros. Sua atuação nesses títulos garantiu-lhe uma série de prêmios. Sua carreira se destaca, no entanto, devido ao alcance internacional, que teve inicio no inglês Journey To The End Of The Night, de Eric Eason. Em 2007, Alice esteve ao lado de atores como Will Smith (Eu Sou a Lenda) e Harrison Ford (Território Restrito). Em 2011, atuou com Anthony Hopkins no filme O Ritual. Além desses títulos, a atriz também participou de produções estrangeiras como Redbelt, Repo Men, Predadores, Elysium, Ensaio Sobre a Cegueira, entre outros. Em 2016, é a protagonista da série $A$ Rainha do Sul, na qual interpreta a mexicana Teresa Mendoza, mexicana que constrói um império financiado pelo tráfico de drogas nos EUA.

Alice Braga também se insere com sucesso no mercado televisual brasileiro, tendo no "currículo" participação na série As Brasileiras, no episódio A Indomável do Ceará, além de ter sido apresentadora do programa Superbonita Transforma, exibido pela GNT. Após quinze anos atuando nas telas de cinema e televisão, o projeto transmídia Latitudes representou a estréia da atriz também como produtora, já que ela foi responsável por diversos processos nos bastidores da realização. De acordo com o Portal Terra ${ }^{11}$, ela participou de reuniões com financiadores e nas articulações para o estabelecimento de parcerias fundamentais na captação de recursos para o projeto.

Outro nome amplamente reconhecido em mídias tradicionais que compõe o projeto é Daniel Oliveira. O ator mineiro é conhecido principalmente pelo seu trabalho na televisão, mas também tem participações de muita relevância no cinema nacional. Na TV, Daniel já viveu diversos personagens em novelas e séries, sendo os mais recentes: Bruno em O Rebu e Chico em Amorteamo.

Entre as produções de que participou no no cinema, destacamos Zuzu Angel,

\footnotetext{
${ }^{11}$ Disponível em: http://cinema.terra.com.br/foi-meio-que-meu-projeto-de-sonho-diz-alice-bragasobre-latitudes,6a79414f2ccb0410VgnVCM5000009ccceb0aRCRD.html (acesso em 02 de março de 2016).
} 
Batismo de Sangue, Jean Charles, 400 Contra 1 - uma história do crime organizado e, principalmente, Cazuza - o tempo não para. O papel apresentado nesse filme impulsionou a carreira do ator e estabeleceu um ponto de referência em sua vida profissional. O envolvimento com o personagem (que demandou 11 quilos a menos a Daniel, além da incorporação de toda mise-en-scène do cantor nos palcos) rendeu-lhe vários prêmios e diversos papéis em outros projetos.

Desse modo, é perceptível que Latitudes foi pensada, além de projeto transmídia, como uma realização de qualidade técnica e estética. Com um "time" renomado em plataformas de mídia tradicionais, a obra que circulou inicialmente na internet teve legitimidade e atraiu pessoas que talvez não se interessassem por uma websérie sem grandes nomes no elenco e na equipe de produção.

Desse modo, o investimento em elenco, roteiro e direção fortes no mercado nacional e internacional da área de realização audiovisual funcionou como índice valorativo da obra Latitudes, o que sem dúvida aumenta não só o seu público potencial, mas também as perspectivas de financiamento para a produção. Se o "desenvolvimento das formas narrativas contemporâneas está diretamente relacionado à emergência da televisão como espaço possível de qualidade artística" (SILVA, 2014, p. 245), Latitudes dá um passo em direção ao reconhecimento também da internet, por meio das plataformas de distribuição em streaming, de espaço possível de qualidade técnica e artística.

\subsection{Latitudes de leste a oeste e norte a sul: um passeio pela diegese}

Nessa etapa do trabalho, realizamos uma imersão aprofundada em Latitudes, descrevendo a trama, os conflitos e as personagens. Para tanto, serão apresentados todos os episódios componentes da websérie, que concentram integralmente a diegese da obra. Ficaram de lado alguns conteúdos televisivos que trazem extras dos bastidores da obra e serão trabalhados posteriormente. É importante lembrar que cada fragmento trazido aqui se passa em uma cidade diferente do mundo, o que facilita sua identificação.

- Latitudes $-1^{\circ}$ Destino - Paris:

No primeiro contato com Latitudes, observamos um quarto desarrumado, indicando que ali ocorrera recentemente algo como uma "noitada". Há peças de roupas espalhadas pelo chão e garrafas vazias de bebidas alcoólicas. Nesse 
momento, o público já começa a entender um pouco sobre as personagens, devido às vestimentas e aos acessórios "descolados" apresentados e às bebidas sofisticadas que consumiram. Durante a sequência, uma voz feminina chama repetidamente (três vezes) pelo nome “José” em off. Na última vez em que o nome é proferido, entra em cena um homem deitado na cama, dormindo. Nesse momento, fica claro que a voz feminina que chamava estava tentando acordá-lo.

Após essa sequência inicial, o destino é claramente exposto. Até então, tudo o que sabíamos sobre a localização do homem (Daniel de Oliveira) dormindo e da mulher (Alice Braga) chamando por ele é que estavam em um quarto. Enquanto se veste, ela abre as cortinas do aposento e revela Paris, em uma região bastante central, enquanto um letreiro apresenta o nome da cidade. Estão no Hotel Mandarin Oriental, na Rue Saint-Honoré, em um dos endereços mais sofisticados da França.

Figura 1: Paris

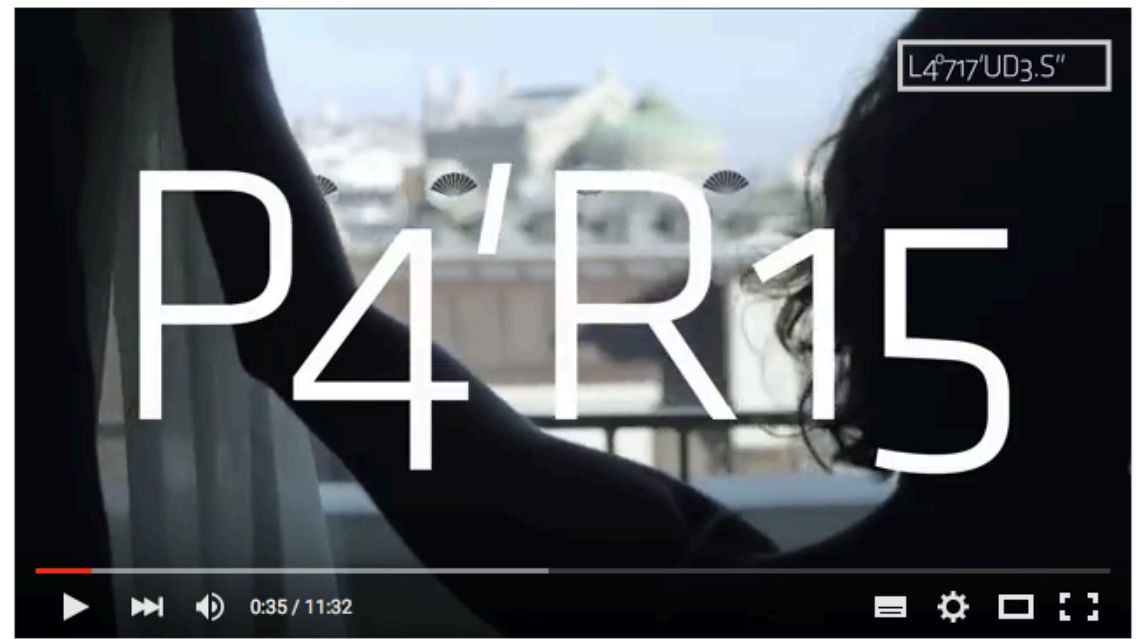

Vista do quarto do hotel em Paris.

A mulher sai para uma varanda e ouve os sons da cidade. Sirenes e buzinas contrastam com o soar de sinos. O contraste também está no cenário apresentado, que mistura guindaste de obras com cúpulas de prédios históricos, em uma alusão à coexistência do antigo e do novo, do moderno e do tradicional na cidade-luz.

Em seguida, um celular toca e a mulher atende, se desculpando pelo "cano" que deu com quem fala do outro lado da linha. Ela reclama de uma "dor de cabeça que não vai embora", olhando para o homem deitado na cama, se referindo a ele como um incômodo para sua rotina atarefada. Entre vários telefonemas, ela é mostrada falando também inglês, revelando o caráter internacional do seu trabalho. 
Tudo isso acontece enquanto pega roupas e sapatos de malas minuciosamente arrumadas, o que nos diz pelo menos duas coisas: 1) ela é uma pessoa organizada e 2) está acostumada a arrumar malas, ou seja, a viajar. Essa sequência também define que o casal está no quarto dela.

A personagem pega um casaco, olha o passaporte e, aparentemente, descobre o nome do homem que está no quarto com ela. Passa a chamá-lo (“José”), aludindo à sequência inicial do episódio. Ele não acorda. O telefone toca novamente e corta para uma cena que mostra a mulher se olhando no espelho do banheiro, já arrumada para sair, falando com a recepção do hotel - pede para ligarem para o quarto em cinco minutos. Ela está decidida a ir sem ele, a deixá-lo dormindo, pois não pode mais se atrasar para seus compromissos.

Quando volta para o quarto, José está de pé, vestindo apenas cuecas, aparentemente meio confuso, olhando ao redor. Eles conversam rapidamente, até que ela lhe pede para se vestir - o apressa pois está claramente atrasada. De repente, ela o aborda e beija sua boca, dizendo "agora não fica aquela dúvida de como a gente se despede, se com um beijo, um abraço...”. Observamos a construção de uma mulher decidida, que tem o controle da situação.

Enquanto ele se arruma, o telefone toca novamente. A mulher pede que José atenda e ele se recusa, dizendo que "pode ser alguém". Aqui, percebemos como o personagem evita envolvimento em sua vida íntima. A impessoalidade é quebrada quando, ao se despedir, ele a chama pelo nome: Olívia. Ela fica surpresa por José sabê-lo e ele esclarce que olhou no passaporte enquanto ela dormia. Ela diz que não precisou de tudo isso pra lembrar o dele - um truque para não se mostrar interessada, uma vez que, ao que tudo indica, ela usou o mesmo artifício relacionado ao passaporte.

Novamente, Olívia diz que precisa ir. Se beijam, ele pede alguns minutos para terminar a conversa. Ela diz que eles não irão mais se cruzar e que não faz diferença. José arrisca que ela é uma mulher que pode se atrasar, calculando um lugar hierarquicamente elevado na carreira. Ele afirma que leu uma coluna dela em uma revista, quando, novamente, um celular toca - dessa vez, o dele. Alguém o apressa, ele diz que está a caminho e desliga.

Olívia pergunta o que ele leu sobre ela, e José responde que sabe que é comprometida, mas não veria problema em um encontro inesperado - só que esse seria um risco que não correria duas vezes. Nesse ponto, percebemos que a mulher 
tem um relacionamento estável que não inclui seu interlocutor. Olívia pergunta se tudo isso estava escrito na revista, e ele diz que não, que essa parte ele "interpretou".

Novamente, um celular tocando. Dessa vez, ela não atende. Já com o rapaz na porta para ir embora, Olívia pergunta até quando ele fica, diz que perdeu "sua revista" e avisa que comprará outra depois. Entende-se que ele tem algo publicado. Depois, ela revela a profissão de José, diz que ele é um fotógrafo conhecido e indaga a razão de nunca terem trabalhado juntos. Ele afirma que não faz moda e pede para que ela não se ofenda, avisa entre risos que não é nada pessoal. Daí, descobrimos que ela trabalha com moda. Em seguida, se despedem, hesitam, se olham, até que ela, sem dizer nada, o beija e fecha a porta do quarto, deixando José do lado de fora.

Após esse grande diálogo inicial, é apresentado um flash backward com cenas do casal na cama, depois entre beijos em um carro, em seguida andando pelos corredores do hotel, em um bar, nas ruas de Paris, em uma casa noturna, em lojas, em um restaurante e em outros lugares. Percebe-se que a sequência ilustra a noite que tiveram de maneira inversa, mostrando tudo que foi feito até terminarem juntos em um quarto de hotel. Por fim, vemos a maneira como se conheceram: Olívia folheando uma revista em uma banca de jornal na famosa esquina entre os tradidionais cafés Les Deux Magots e de Flore. José passa, hesita, olha a capa da revista e fala "essa foto é minha".

Assim, o casal se conhece e passa a primeira noite junto. Como fica claro pelo diálogo que ocupa um pouco mais de oito minutos dos nove minutos e meio que compõem a trama do primeiro episódio, não está nos planos que eles se encontrem novamente. Também é interessante pensar que muito pouco foi explorado da cidade que ambientou o episódio, já que a maior parte dele ocorreu dentro de um quarto de hotel. Com algumas bases da construção das personagens reveladas, passemos ao próximo encontro.

- Latitudes - $2^{\circ}$ Destino - Londres:

O segundo destino começa com um encontro marcado entre José e Olívia no bar do Park Lane Hotel, em Londres - um lugar cosmopolita e sofisticado. Enquanto o fotógrafo pede uma cerveja, ela faz questão de deixar claro que os dois estarem novamente na mesma cidade é uma coincidência, não foi algo proposital. 
Novamente, se perguntam se já haviam se encontrado antes no âmbito profissional e Olívia retoma o que se passou em Paris e lembra que ele não trabalha com moda, marcando essa posição aparentemente ideológica do rapaz.

Figura 2: Londres

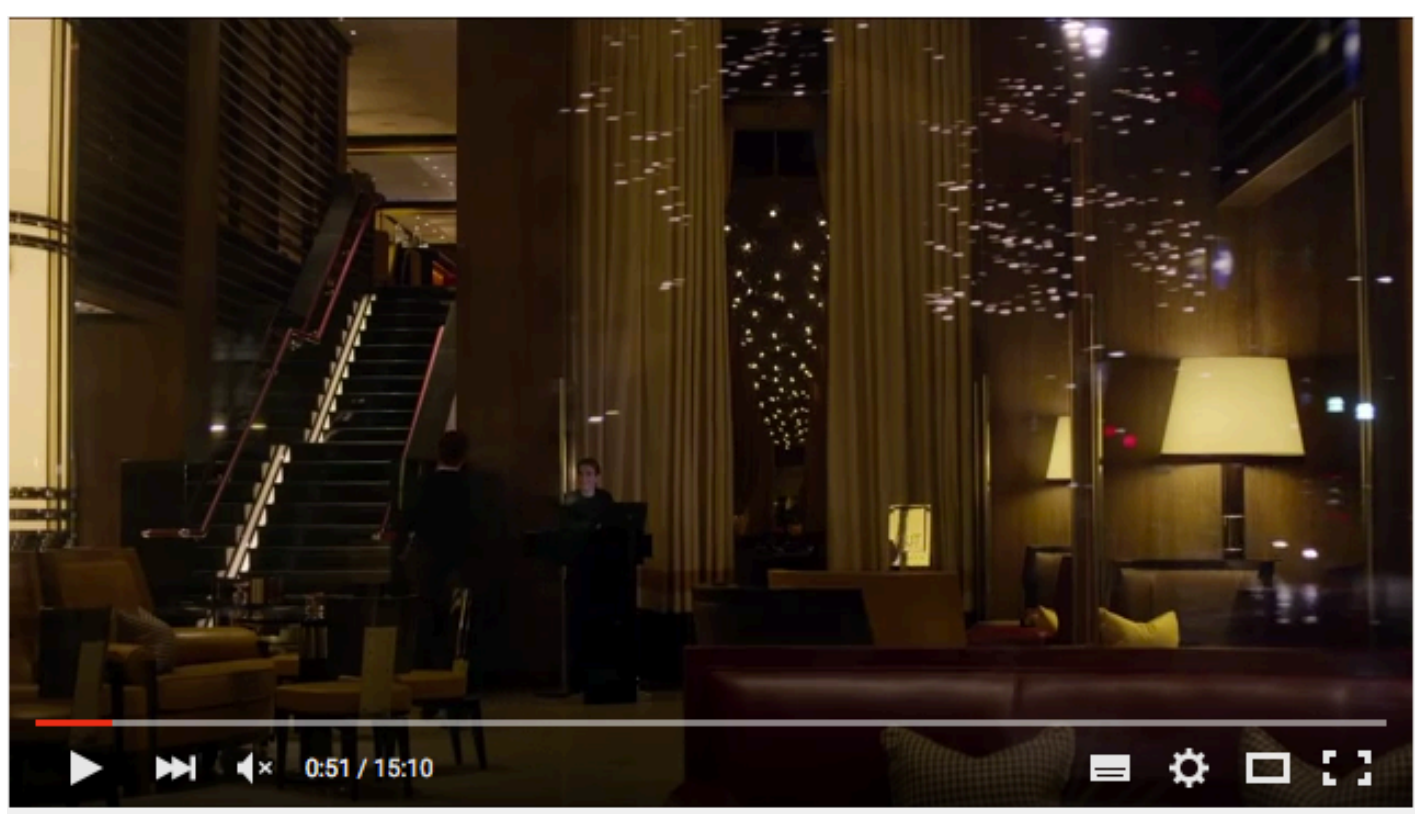

Bar do Park Lane Hotel, em Londres.

As analogias ao diálogo do primeiro episódio continuam quando Olívia diz que ele acha o mundo da moda superficial, consumista, ligado apenas à imagem. $\mathrm{O}$ que o incomodaria, por ele ser um fotógrafo diferente, “um artista sensível”. José pergunta se ela leu isso em algum lugar e ela responde que não, que "eu interpretei”. Aqui, percebemos que a personagem não quer estar em posição vulnerável. Ao sentir que ele teve acesso a informações suas em uma revista anteriormente e fez conjecturas a seu respeito, ela se coloca na mesma situação, surpreendendo o fotógrafo.

Os dois trocam elogios e José diz que ela na verdade fez um convite tendencioso ao chamá-lo para tomar um drink após a festa em que estavam. Daí, é possível perceber que já estavam juntos em algum lugar antes. Olívia, como era de se esperar, nega e diz que o convite não tem segundas intenções e que só chamou porque no lugar em que se encontravam não havia gin. Novamente, vemos um jogo de sedução entre o casal, no qual ela se faz de desinteressada e ele sutilmente avança relação adentro. José coroa o diálogo perguntando, enfim, quanto tempo ele teria antes de ela começar a dizer que estava atrasada. 
A conversa entre os dois continua com lembranças de Paris, da noite que passaram juntos e das possibilidades de continuidade do relacionamento. Olívia sempre na defensiva, por vezes dizendo que já era hora de se despedirem, até José perguntar quantas bebidas ainda seriam necessárias para ela chamá-lo para subir ao seu quarto. Instintivamente, a mulher responde: "pede uma champagne".

Os dois vão para o quarto, um ambiente espaçoso e refinado. Surpreso, José fala "que lugar incrível! O que você faz para te colocarem num quarto desse tamanho?". Olívia responde que, por conta da revista, as pessoas gostam de mostrar o que têm de melhor. Nesse ponto, entendemos que ela trabalha em uma revista, provavelmente como editora de moda. E que tem uma posição de destaque. Diz, ainda, que às vezes se surpreende, mas às vezes percebe que é só propaganda. É uma mulher, portanto, acostumada ao luxo e à sofisticação.

Começa, então a falar sobre a vida de viagens e hotéis, José pergunta se ela não se cansa e revela que está exausto de tudo isso, dessa vida longe de casa e sem raízes. Aparecem, então, imagens distintas dos dois em Londres, ele no metrô, passeando pelas ruas, ela em um desfile de moda, em um avião... Olívia confessa que fica mais confortável em um quarto de hotel do que em sua própria casa, pois lá tem "muita coisa encaixotada, muita prateleira vazia, e a preguiça".

Nesse ponto, o espectador fica entre cenas dos dois no quarto e de volta à conversa no bar, na forma de back forwards. Ele pergunta qual a chance de se encontrarem novamente em um futuro próximo e a editora, evasiva, não responde e diz que "sem querer é quase impossível”. José insiste e pergunta para onde ela vai quando deixar Londres. Ela revela que irá para casa e diz que ele com certeza terá que "voltar para algum lugar".

O casal aparece novamente no quarto, se beijando, e, em seguida, já à luz do dia (nublado) em um parque londrino. Fica evidente que passaram a noite juntos e, dessa vez, ela não o expulsou da cama pela manhã. A despedida começa e o fotógrafo se mostra ansioso, indagando como farão para se encontrarem novamente. Ela responde que tem o número, e gera um discreto protesto, visto que ele não tem o telefone de Olívia. Resignado, diz que "a bola” agora está com ela.

Beijam-se e, em uma cena emblemática, seguem em direções opostas. Caminhos distintos, cada um em seu rumo, José recebe uma mensagem no celular. Tira do bolso, lê e sorri, olhando para trás, na direção da editora de moda. Agora ele também tem o número dela. 
○ Extra: $2^{\circ}$ Destino - Londres EXTRA/ London Fashion Week

O segundo webisódio disponibilizado no YouTube tem uma particularidade em relação aos demais: um pequeno vídeo extra, gravado durante o desfile da Burberry na London Fashion Week de 2013. Com um minuto e cinquenta segundos de duração, o conteúdo revela basicamente Olívia em meio aos bastidores dos desfiles, rodeada de câmeras e repórteres.

Além de conversar com pessoas do mundo da moda, percebe-se que ela está sempre ocupada, falando ao celular ou sendo requisitada pela imprensa. Olívia também ocupa lugar de destaque, na primeira fileira do desfile. Desse modo, mais informações vão construindo a personagem, localizando-a em lugar de relevância internacional, como uma profissional de sucesso.

Figura 3: Desfile em Londres

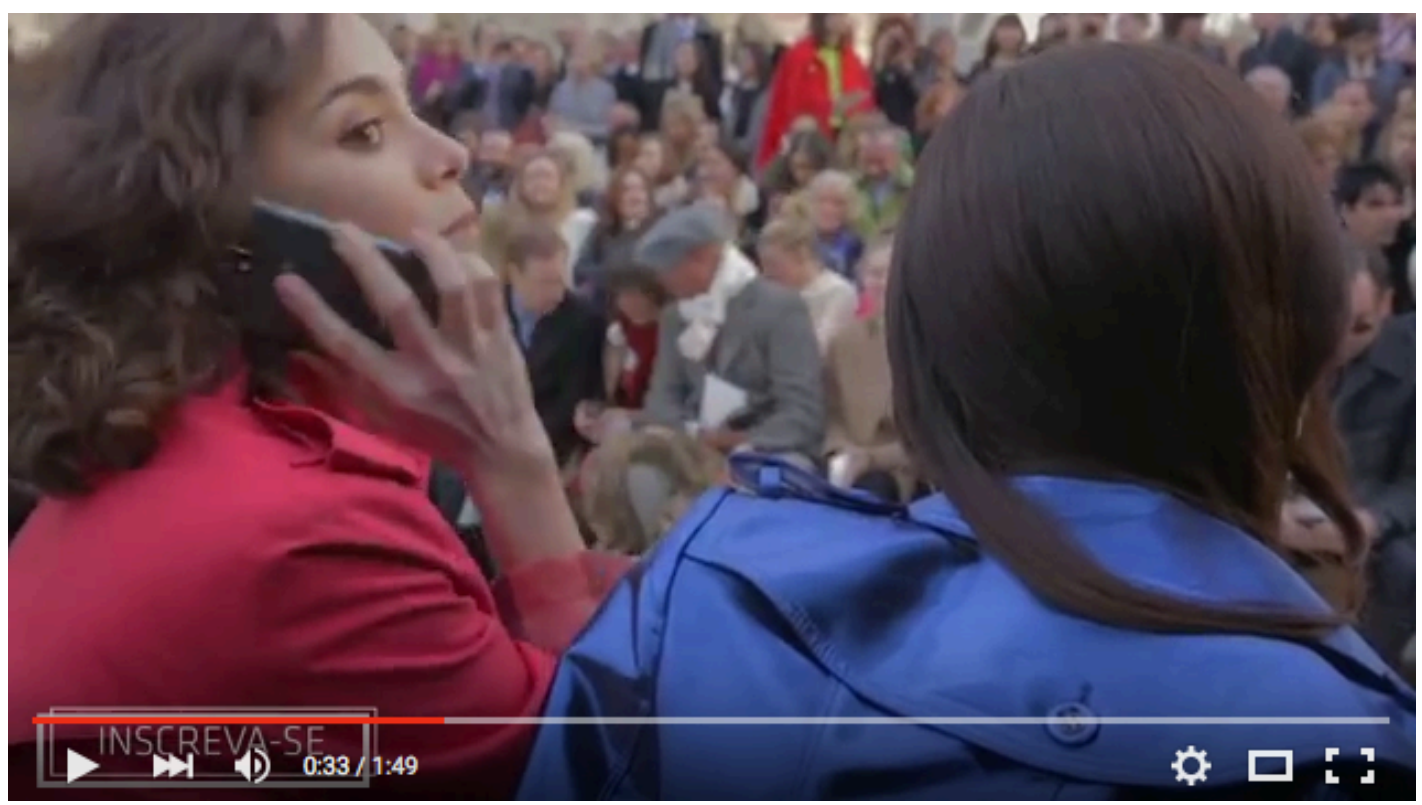

Olívia no desfile da Burberry na semana de moda de Londres, 2013.

O evento também pode ser uma dica da festa onde Olívia e José estavam antes de se reunirem no bar do Park Lane Hotel, apesar de isso não ficar muito evidente. É possível, no entanto, inferir que estavam no coquetel pós-desfile e depois seguiram para o encontro em um lugar mais reservado.

O conteúdo extra também traz legitimidade à construção da personagem, visto que Alice Braga efetivamente se envolveu no mundo da moda e pesquisou sobre blogueiras, produtores e jornalistas ligados ao meio. Além disso, como fica 
claro, participou de desfiles e eventos que a ajudaram a compor a personagem Olívia.

- Latitudes $-3^{\circ}$ Destino - Veneza:

O terceiro destino de Olívia e José, pela primeira vez entre os webisódios apresentados até então, começa com um clima menos cosmopolita ou global. Ambientada por um som de cítara, a sequência inicial revela José comendo com as mãos em um lugar aparentemente oriental, com imagens de deuses hindus, narguiles e itens da cultura indiana espalhados - a essa altura, o local já foi identificado como um restaurante. Apesar da aclimatação exótica, o fotógrafo toma uma cerveja Heineken durante a refeição, o que revela sua conexão com hábitos de consumo ocidentais.

Figura 4: Veneza

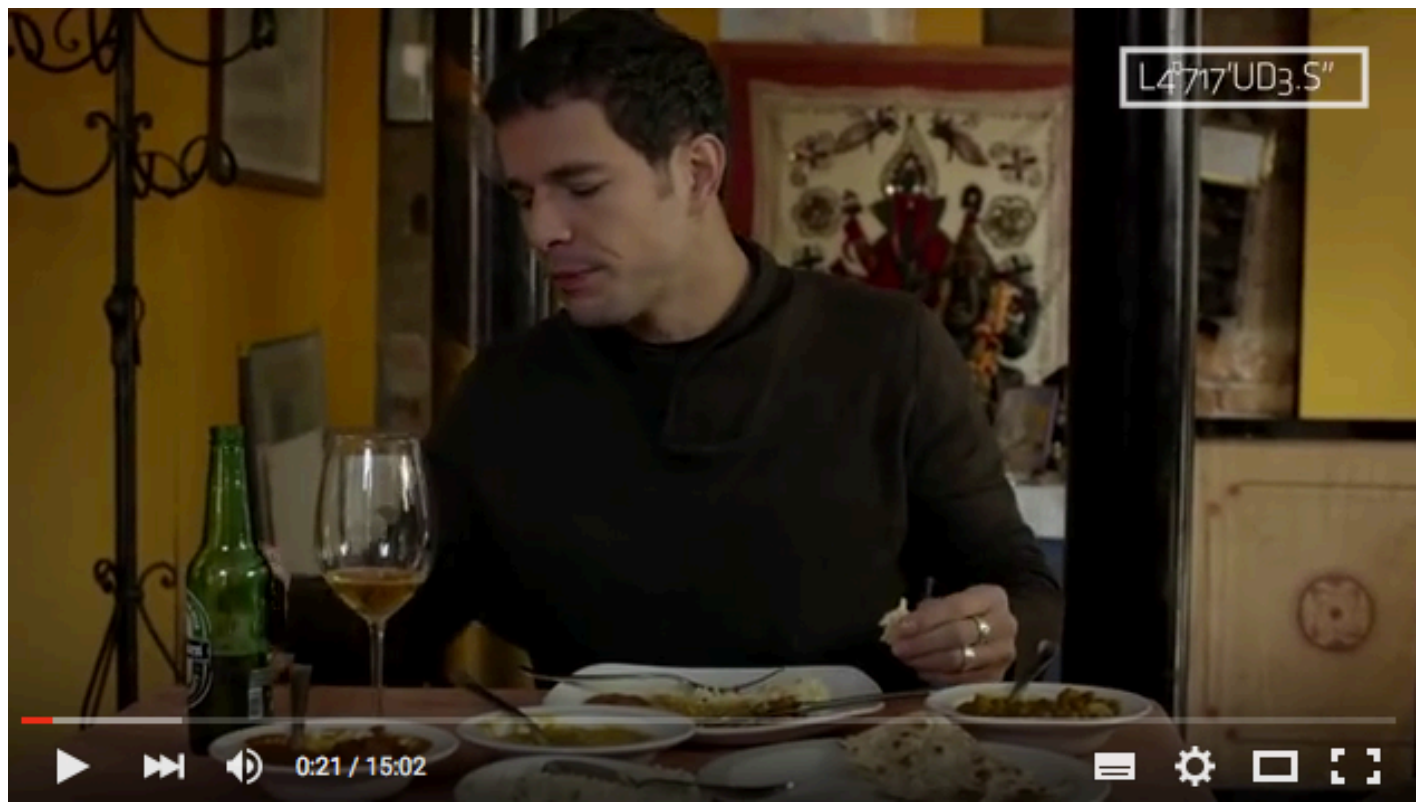

José no Restaurante em Veneza.

A não ser por suas breves explorações pelas ruas de Paris ou pelo parque em Londres, rapidamente mostrados nos episódios anteriores, é a primeira vez que um dos personagens se encontra fora de um quarto de hotel, ou de um avião ou de um táxi. Até o momento, percebe-se a predominância de não-lugares (Augé, 1994), conforme será exposto no capítulo de análises, como uma das estratégias adotadas pela produção. Enfim, o clima oriental e exótico é quebrado pelo som de uma notificação de mensagem no celular de José, o que o faz rapidamente deixar o 
lugar, revelando a cidade de Veneza, na Itália.

Enquanto anda apressado pela cidade, ele troca mensagens com Olívia, que está em meio a um shooting de moda em um aposento luxuoso. Depois da Heineken, é a vez de outro patrocinador ser exibido, a marca de artigos capilares Wella (da P\&G), em sua linha ProSeries. Uma impressão exibindo o produto é vista nas mãos de Olívia, revelando que a sessão de fotos em questão trata disso. Enquanto trabalha, a editora está sempre ao telefone.

Figura 5: Shooting em Veneza

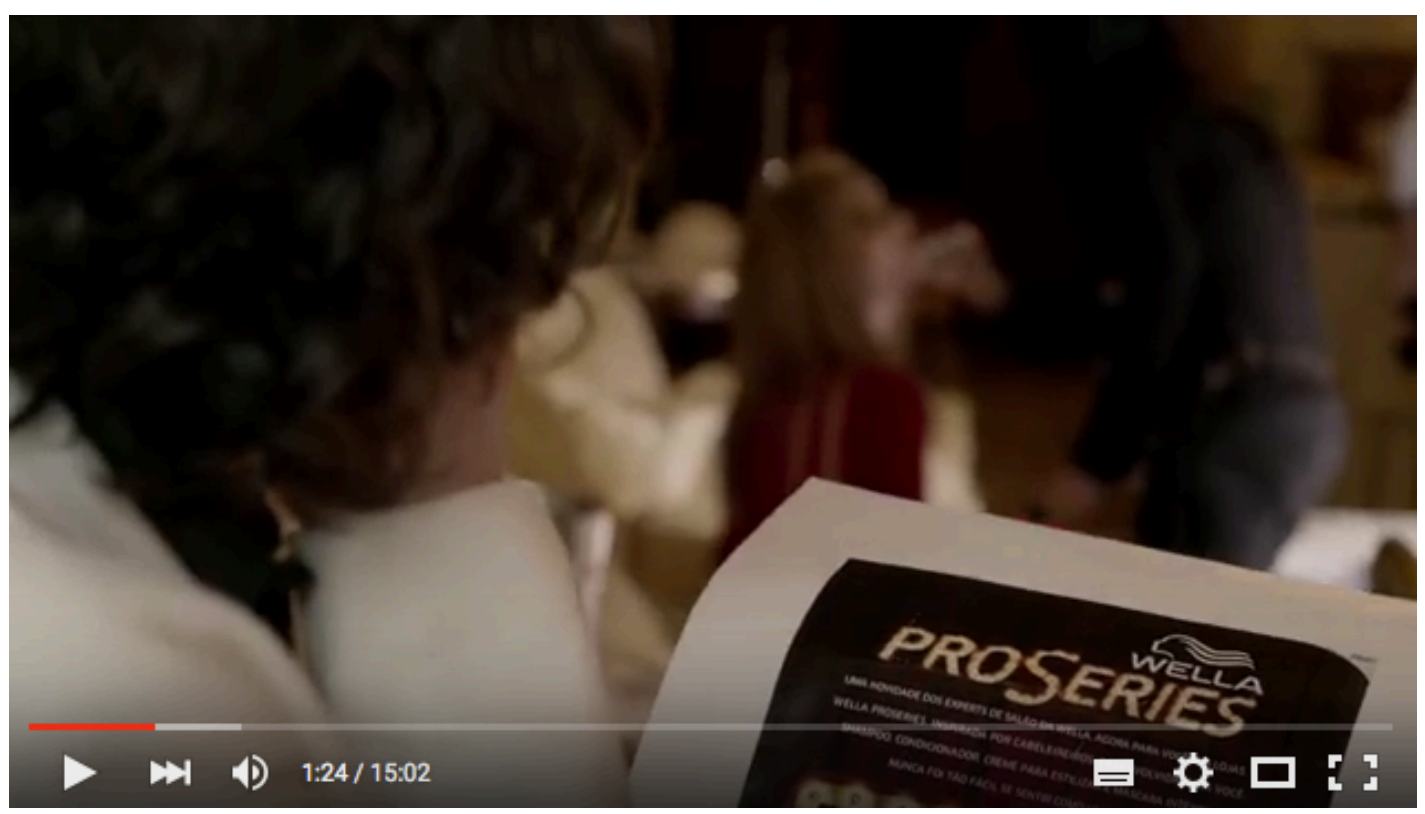

Produto da P\&G durante um shooting de Olívia.

Novamente, José aparece pela cidade, dessa vez em um táxi (que em Veneza assume a forma de barcos, não carros), com a famosa Piazza San Marco ao fundo. Sons de aves, de sinos, o clima da cidade é de introspecção e nos transporta novamente àquele espírito oriental. A produção de Latitudes marcou bastante as influências que Veneza tem de lugares exóticos, devido à sua atuação como entreposto comercial para o trânsito de especiarias entre a Europa e a Ásia durante a baixa Idade Média.

Do táxi, o fotógrafo finalmente chega ao lendário Hotel Danieli, construído no século XIV e um dos mais luxuosos de Veneza. Após circular pelo prédio, José se senta, aparentemente à espera de Olívia. Novamente, ela está no controle da situação: devido aos seus sempre inadiáveis compromissos profissionais, quando não o abandona abruptamente, o faz esperar para encontrá-la. 
Finalmente juntos, no quarto, os dois apreciam a arquitetura e a história do lugar. Pela primeira vez, revelam detalhes dos aposentos, reconhecendo-o como um local diferene dos outros quarto de hoteis em que já ficaram. Estão na suíte Doge Dondolo, a mais luxuosa do Danieli, com móveis e afrescos do século XVIII. Quando o clima romântico é quebrado pela editora de moda perguntando as horas (novamente, ela parece ter pressa), José reclama que teve de pegar dois vôos para encontrá-la, e que ela poderia tê-lo chamado com mais antecedência.

Sempre com ar indiferente, ela diz que não sabia que estaria em Veneza, que não estava em seu cronograma. O fotógrafo estranha e pergunta se a idéia veio de repente, visto que Olívia, até então, sempre se apresentou como uma mulher metódica, controladora e organizada. Ela confessa que não, que a idéia já estava em sua cabeça há um tempo: o que viera de repente foi a idéia de encontrá-lo precisamente naquele dia. Mais uma vez, ela dá as cartas.

Enquanto toma champagne, ela escuta José falar que sabia que teria trabalho com esse romance e pergunta ao fotógrafo se ele está arrependido. Fica impassível diante da negativa, e o rapaz prossegue dizendo que sua equipe nem acreditou quando ele terminou rapidamente as fotos. Nesse ponto, ele revela sua ansiedade para encontrá-la, visto que a surpresa da equipe mostra que não é comum que ele acabe rapidamente uma das suas sessões fotográficas.

José sente cheiro de maresia e abre a sacada do quarto, admirando o lugar. Divaga sobre a ilusão que um quarto e hotel representa, locais onde as pessoas passam e se vão. Conclui que o aposento onde estão agora é diferente, que ali as pessoas ficam. Refere-se à história do lugar, dizendo que os dois não estão sozinhos por lá. Falam sobre o quadro de Doge Dandolo pendurado na parede, antigo nobre que habitou a câmara e dá nome a ela. Enquanto conversam sobre os detalhes do quarto, José usa um abajour para revelá-los por meio da luz.

Finalmente, começam a falar sobre a iminente despedida. José diz que não queria que precisassem ir e que há mais fantasmas esperando por eles lá fora do que dentro do quarto antigo. Falam sobre suas casas, os dois revelam que estiveram em seus respectivos lares desde o último encontro. Mas rapidamente mudam de assunto, deixando claro que o tema "lar" não agrada. Há mistérios que envolvem o casal e são alimentados pela efemeridade de seus encontros.

José revela que está sofrendo por antecedência porque o tempo deles juntos irá acabar, diz entre risos que "é a única mulher que conhece que vem com um 
timer acoplado". Pergunta para onde ela tem que ir no dia seguinte e em qual horário, e ela responde "em algumas horas". Novamente, um encontro rápido, dos quais o fotógrafo admite estar cansado. Gostaria de vê-la com mais tempo. Apesar de a ideia agradar, Olívia diz que não sabe como nem quando fariam isso; José retruca e argumenta: é só ela querer. Percebe-se que ele se submete à conveniência dela, que toma o controle da situação novamente e finaliza com um "eu vou pensar e te aviso".

Dormem e José acorda pela manhã com o barulho de malas sendo fechadas. Olívia está partindo, mais uma vez atrasada. Ao se despedir do fotógrafo, no entanto, diz que podem se encontrar no fim do mês e deixa a cargo dele a escolha do lugar; "qualquer lugar". Pede, todavia, que ele escolha logo, pois não quer ser pega de surpresa. Ela libera as rédeas, mas não tanto. Deixa o quarto e pede para que ele fique e descanse um pouco mais, apesar de ele ter sugerido acompanhá-la. Olívia parte e adentra a manhã fria e cinzenta de Veneza.

Mais tarde, já tomando café da manhã, José contempla a cidade sozinho. Parece pensativo e, de certa maneira, contrariado. A conversa da noite anterior revelou seu incômodo com a rapidez dos encontros com a editora de moda e nos leva aos problemas que o casal irá enfrentar em sua próxima reunião.

- Latitudes $-4^{\circ}$ Destino - José Ignacio:

O primeiro destino do casal fora da Europa acontece em José Ignacio, no Uruguai. É um balneário perto de Punta del Este, mas com menos apelo turístico. Afinal de contas, os dois já declararam em momentos anteriores que não se identificam como turistas, com o modo prosaico de agir de quem não é habitué dos grandes centros mundiais. De todo modo, o episódio começa com Olívia dentro de um carro (parado), contemplando um campo verde. Uma mão no volante e a outra no celular, que logo toca, como de costume. Ela atende falando em espanhol e dessa vez, o assunto não parece ser trabalho. Em meio a uma conversa rápida, ela fala com seu interlocutor sobre contas e se despede mandando um beijo. 


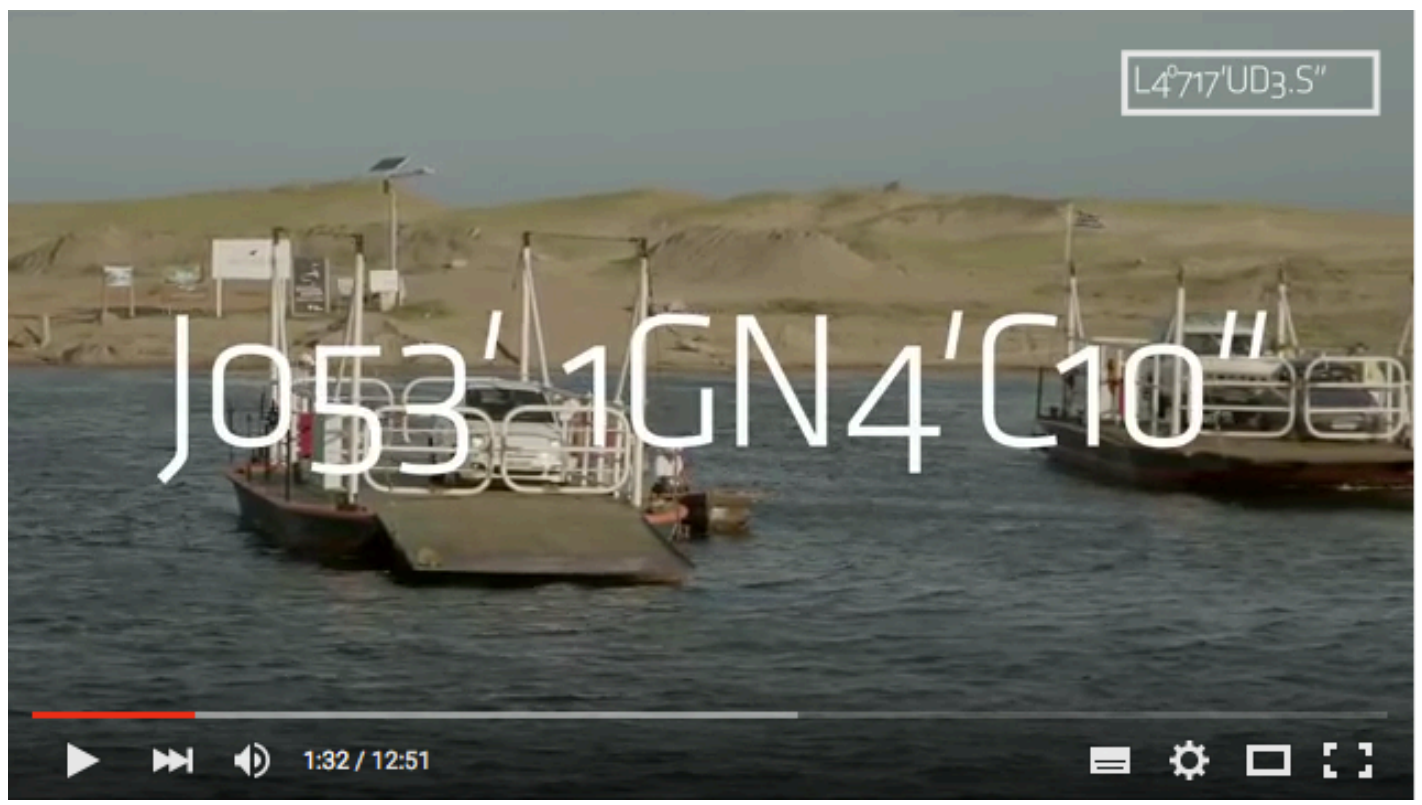

Balsa em José Ignacio.

Ainda dentro do carro, é possível ver a marca de mais um financiador de Latitudes, a Fiat. Após desligar o telefone, Olívia entra em uma balsa. Mantém o ar contemplativo e chega a sair do veículo para apreciar melhor a vista. Seu automóvel é o único na embarcação, o que nos dá a ideia de um lugar exclusivo. Ela volta a dirigir, passa por estradas de terra, o episódio é marcado por esse percurso, revelando o isolamento do destino. Após encontros em grandes centros urbanos, dessa vez o ambiente é totalmente bucólico.

Apesar disso, o trabalho não é deixado de lado. Antes de encontrar Olívia, José, que já estava no hotel, fala ao telefone sobre assuntos profissionais, enquanto usa o computador. Ao ouvir o barulho de um carro se aproximando, deixa tudo de lado e vai ao encontro da editora de moda. Os dois estão na Estancia Vik, uma hospedaria tradicional e luxuosa no Uruguai, que junta requinte e sofisticação ao contato com a natureza. É um lugar isolado, tranquilo e exclusivo, conforme o percurso até lá sugeriu.

Olívia e José se cumprimentam com um beijo apaixonado e logo estão no quarto. A primeira pergunta proferida pelo fotógrafo é "até quando você fica?" e ela é evasiva, respondendo apenas que correu muito para chegar até lá. A editora insinua que ele teve medo de que ela não viesse e ele retruca que essa deve ter sido a razão pela qual ela não desistiu. Novamente, um jogo de sedução e controle: “você tá querendo dizer que eu adoro ter razão, não tá?”, diz Olívia. 
Os dois combinam de sair para jantar, o que é raro devido à constante falta de tempo juntos. Enquanto Olívia sai para tomar banho, José pega o celular e liga para alguém. Ela esquece algo na mala e sai do banheiro, quando José termina abruptamente a ligação. O clima fica pesado, a editora pede desculpas por ter interrompido e diz que não queria atrapalhar; José retruca e fala que ela não atrapalhou, que não era ninguém... A situação traz à tona que eles têm uma vida misteriosa fora dos encontros frugais.

Discutem, ele insiste que falava com um assistente e ela revela que não tem interesse em saber, que cada um tem seu mundo, interesses e pessoas em suas "vidas reais". Olívia tenta acabar o conflito dizendo que "se a gente não tivesse uma vida do lado de fora, uma vida que, aliás, que envolve outras pessoas, a gente estaria se encontrando num lugar que eu chamo de casa. Num lugar que você chama de casa. Que, aliás, eu não faço uma porra de ideia de onde fica. Eu não vou ficar discutindo relação com você, até porque a gente não tem uma”.

Olívia deixa o quarto e vai para o lado de fora da propriedade, um grande espaço aberto. José a segue e diz que não vai deixá-la sozinha porque esforçou-se muito para encontrá-la ali. Olívia se indigna e pondera que ela que foi atrás dele e abriu mão de coisas para estar lá. Aparentemente, os dois consideram que ceder para que o encontro ocorresse foi um esforço hercúleo.

José a segura bruscamente e diz que ela é uma ilusão. Olívia revela que sua vida está uma bagunça, já estava antes de o fotógrafo aparecer. Mas antes, ela não remoía sua situação sentimental e inclusive já decidira não fazer nada a respeito. “Algumas coisas na vida não mudam. Inclusive, eu”, ela pondera. Aparentemente, José a fez se confrontar com um relacionamento frustrado que ela leva. Ele a tira da sua zona de conforto, a faz perder o controle da situação e a coloca diante da necessidade de mexer no que até então era estável. A maneira como a personagem foi contruída até aqui nos indica que isso a perturba muito.

Enfim, ânimos mais calmos, José diz querer que ela fique. Ela não sabe se é melhor assim, não quer machucá-lo ou se machucar. Mais uma vez, a escolha está em suas mãos, ela toma as rédeas das ciscuntâncias. Mostra seu desconforto com um derradeiro "isso não estava nos meus planos”, o que leva o episódio ao fim. 
- Latitudes $-5^{\circ}$ Destino - São Paulo:

São Paulo é o primeiro (e único) destino brasileiro de Latitudes. Também pela primeira vez, o ambiente remete a uma casa, e não a um quarto de hotel. É nessa casa que o episódio começa, retratando José ao chegar de viagem, carregando uma mala de mão. Ele joga a mala e um agasalho em cima da mesa e começa a verificar a casa. Abre janelas, vê se há algo para comer na geladeira e começa a jogar vários produtos na lixeira, provavelmente estragados - nos dá a impressão de estar chegando em casa depois de uma longa temporada fora, como, sabemos, seu trabalho exige.

O fotógrafo desarruma a mala e cheira suas roupas. Ao fazer isso, lembra instantaneamente de Olívia, compartilhando momentos íntimos. Coloca as roupas na máquina de lavar e, nesse momento, novamente uma inserção mercadológica de um dos patrocinadores, dessa vez o produto de limpeza de roupas Ariel. É uma mercadoria da Procter \& Gamble, que efetivamente contribuiu com a produção de Latitudes.

Figura 7: Merchandising P\&G em São Paulo

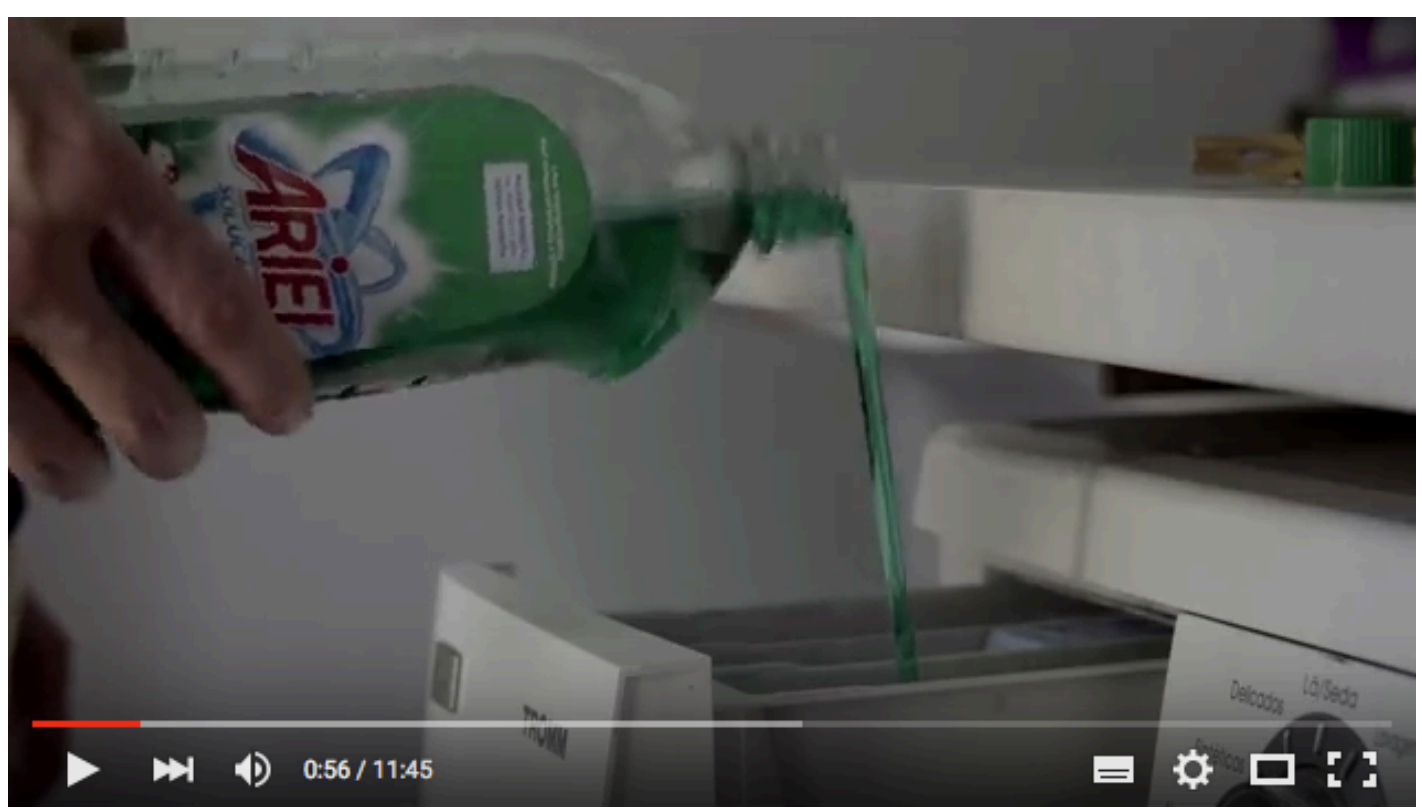

José utilizando um produto P\&G em suas atividades domésticas.

Em seguida, de maneira inédita, uma nova personagem entra na trama. Uma mulher que fala bastante e rapidamente, sobre a vida e seus planos ao lado de José. É a namorada do fotógrafo, que tenta desenvolver uma conversa enquanto ele 
permanece desinteressado. Ela é interpretada pela atriz brasileira Elisa Volpatto e planeja abrir um restaurante. Para isso, sugere que passe a viajar com ele, para "visitar os lugares, trazer umas referências".

Ele tem uma expressão de quem não gostou muito da idéia e a sequência seguinte já apresenta a moça discutindo exaltada, querendo saber "quem é ela". Muito nervosa, seu comportamento indica que ela desconfia que ele mantém um romance secreto. $\mathrm{O}$ sol ainda brilha na sacada elegante onde o casal briga quando ela pergunta quem é a amante e, na sequência, já é quase noite e a identidade da editora de moda ainda não foi revelada. Ela tenta adivinhar e enquanto não consegue uma informação do namorado, segura sempre uma taça de vinho em sua mão.

\section{Figura 8: São Paulo}

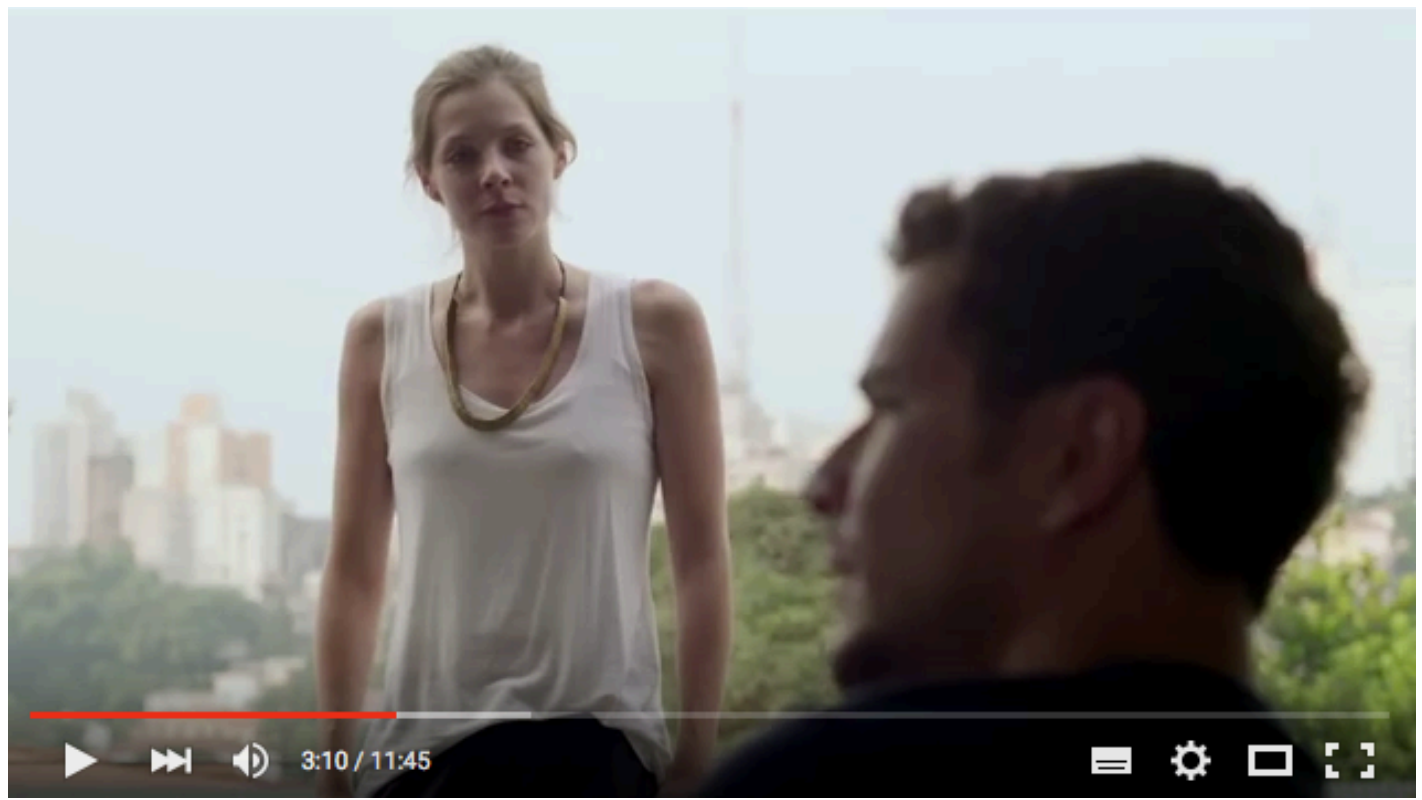

O fotógrafo José e sua namorada.

O nome da nova personagem da trama é revelado em meio à discussão, que segue noite adentro: Aline. Ela se pergunta se ainda pode ter esperança, se José passa por uma fase com essa "nova mulher" que conhecera. Talvez pela efemeridade da relação que sustenta com Olívia, ele mesmo não seja capaz de ter certeza ao responder essa questão: "pode ser". Não dá à mulher com quem conversa agora sequer a dignidade da certeza.

Exausta pela briga e embriagada, ela dorme no sofá sem conseguir nenhuma resposta de José: seja quem é a amante, seja sobre sua disposição em continuar com 
ela ou não. Chove e, enquanto ela dorme, ele permanece pensativo ao seu lado. A cena é cortada por imagens de José caminhando em uma estrada de terra que leva à praia. O dia ainda está amanhecendo e ele contempla o mar do litoral norte de São Paulo. Lembra de um trecho da conversa com Aline, no qual ela pergunta se ele não estaria passando por uma fase, se amanhã não acordaria cedo com vontade de levála para passear na praia, como faziam no começo do namoro. Dessa vez, ele foi sozinho.

Enquanto ele tenta ligar para alguém, são exibidas imagens de Olívia em algum outro país, provavelmente europeu, a julgar pelas roupas de frio que usa. Ela observa um jogo de tênis em um parque e não recebe notificação alguma no celular. Aparentemente, ele não conseguiu completar a ligação.

- $\quad$ Latitudes $-6^{\circ}$ Destino - Porto:

O sexto destino começa mostrando uma vista do alto da cidade do Porto, ao norte de Portugal. José anda sozinho pelas ruas até chegar ao Hotel Teatro, um lugar tradicional no centro histórico. Larga suas coisas no quarto e se prepara para entrar no banheiro. Nesse momento, mais uma inserção mercadológica de um produto P\&G, dessa vez a espuma de barbear da Gillette. Ele faz a barba e toma banho, cenas rápidas.

Figura 9: Product Placement Gillette

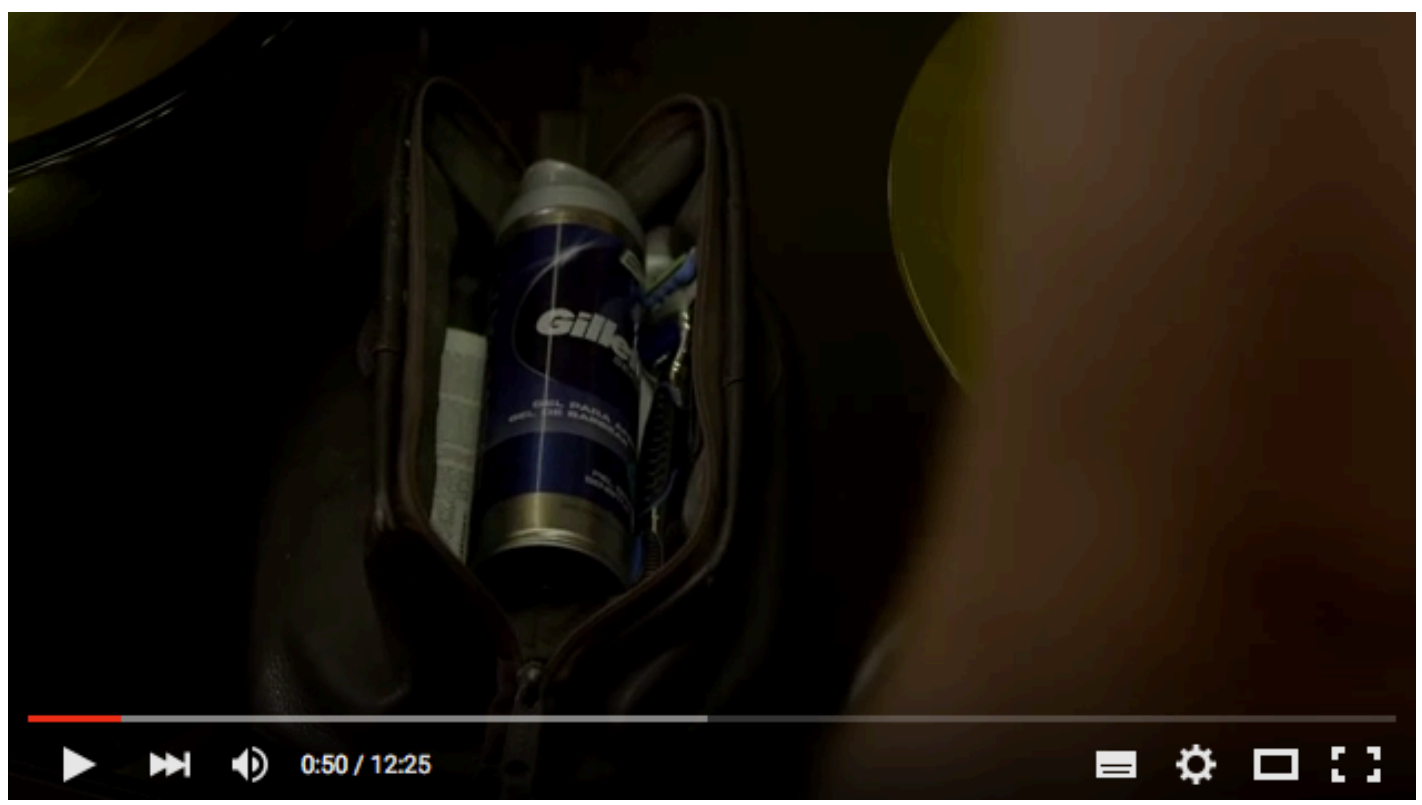

Product placement: Gillette. 
Após sair do banheiro, José faz uma ligação pelo celular, a qual não é atendida do outro lado da linha. Impaciente, ele arremessa o telefone na cama e se deita. Está dormindo quando alguém bate à porta e o faz levantar. Atende: é Olívia, que chega para o encontro.

Os dois se relacionam intimamente na cama e, em meio aos beijos e carícias trocados, a editora de moda revela que estava com saudades e pergunta o que o levou até Portugal. Ele responde que foi fotografar uma modelo e aproveita para indagar de onde ela vem para encontrá-lo. Veio de Londres, com uma escala em Madrid. Aparentemente, essas conversas corriqueiras mais descontraídas pós-coito indicam que eles não trocam muitas informações via celular, e-mail ou o que seja. Nos levam a entender que marcam os encontros e vão, sem entrarem em detalhes sobre suas vidas fora dos quartos de hotéis.

Olívia olha séria para José e diz que queria muito ficar, mas não pode. Ele já está quase resignado com as impossibilidades de Olívia e apenas lembra que não era esse o combinado. Ela sente muito, mas insiste que logo precisará partir. Queria aproveitar o tempo para conhecer a cidade, nunca havia ido até lá. Desanimado, ele diz que está frio e chovendo, não vale a pena. Confrontada pelo abatimento do rapaz, que não se conforma com a fugacidade desse (e dos outros) encontro, ela pede reconhecimento pelo fato de ter aparecido. Revela que terá que pegar um vôo "longo e diurno" devido à passagem pelo Porto.

José cede e os dois saem a caminhar pela noite nas ruas do centro histórico. Conversam sobre o trabalho do fotógrafo e se beijam em uma das poucas cenas externas que compõem a trama. Inesperadamente, Olívia diz que ele fica bem com uma parede ao fundo, tira o celular do bolso e o fotografa. Voltam a se beijar e a aventura no mundo exterior termina: retornam ao quarto. Ali, ele pergunta se a viagem que ela fará logo mais é "de volta", e a editora questiona se quer saber se ela está voltando para casa. Ela diz que "mais ou menos, quase". 


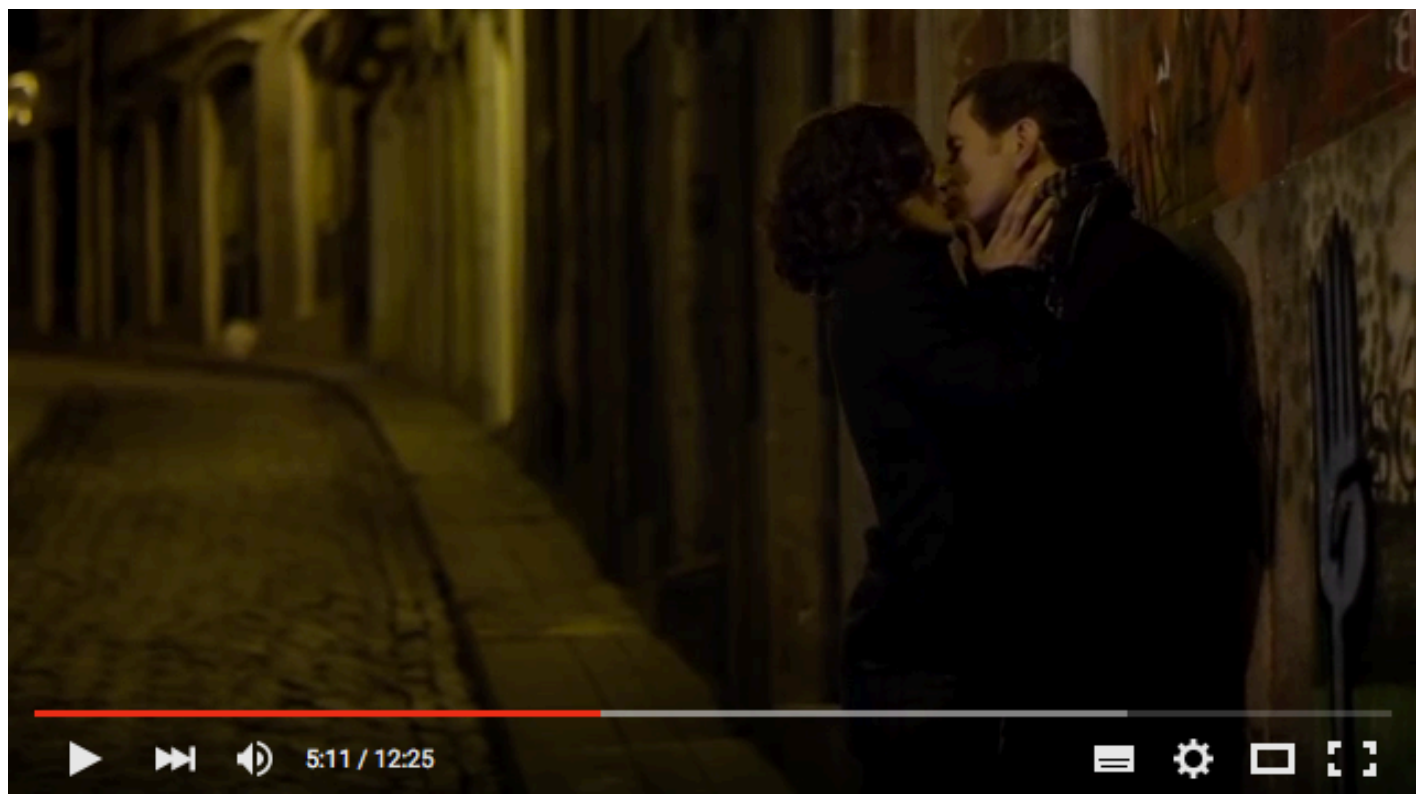

Olívia e José se beijam nas ruas do Porto.

Diante da resposta, José revela que gostaria de convidá-la para conhecer sua casa. Ela brinca, pergunta se ele ficará recolhendo porta-retratos antes de sua chegada, para esconder a namorada. O fotógrafo revela que não tem mais namorada. Assustada, Olívia diz que acha que ele foi precipitado e pergunta a razão de falar sobre isso agora. Afirma, ainda, que ele não fez isso por causa dela, mas por ele mesmo. Fica visivelmente irritada com a situação, gostaria de ter sido avisada antes de ele desmanchar o relacionamento - novamente, controle.

Talvez a iniciativa de José tenha levado Olívia a se sentir pressionada a fazer o mesmo em sua casa, com seu próprio relacionamento. Isso ela não consegue aceitar, tal nível de "intromissão" em sua vida sem o seu consentimento. Mais calma, pergunta quais os planos dele, que revela que ficará mais uns dias na cidade, "quem sabe encontra outra garota mimada para fazer companhia durante a sua folga". Ela levanta irritada e recebe um pedido de desculpas. Diz mais uma vez que tem que ir, o que faz o fotógrafo estourar: "não consigo mais ouvir você dizendo isso".

Ele diz para ela ir embora, mas ir de vez. Deixá-lo em paz. Olívia pede outra chance e ele fala que não é possível dar mais nada a ela, a não ser um conselho: "sai da sombra, para de se esconder no escuro". Sai e a deixa sozinha no quarto. Ela fica pensativa no cômodo enquanto José caminha novamente pelas ruas do centro histórico do Porto, tal qual na primeira cena do webisódio. Mais uma vez, como em 
José Ignacio, as coisas não terminam bem para o casal e a efemeridade de seus encontros e a instabilidade da relação voltam a incomodar

- Latitudes $-7^{\circ}$ Destino - Buenos Aires:

O sétimo destino da produção seriada começa novamente em um quarto de hotel. Olívia dorme em meio à bagunca, com restos de comida e roupas femininas e masculinas espalhadas. Acorda com o barulho da cidade - carros e buzinas -, toma um copo de água e vai em direção à janela para observar a rua. Contempla um cruzamento entre avenidas muito movimentadas, está em uma suíte do Park Tower Hotel, um sofisticado edifício da capital argentina.

Em meio à desordem, Olívia procura algo em sua bolsa, nas gavetas e na cama desfeita. Sem sucesso, olha também no banheiro e embaixo de jornais. $O$ telefone do quarto toca e, na cena seguinte, ela caminha pelo saguão luxuoso do hotel. Vai para o Varela Varelita, um café tradicional no bairro de Palermo Viejo, em Buenos Aires. Ao chegar, um homem (interpretado pelo argentino Michel Noher) está à sua espera. Os dois se cumprimentam com um beijo na boca e conversam em espanhol. Depois de José ter feito isso em São Paulo, é a hora da editora de moda se confrontrar com seu relacionamento fora dos rápidos encontros com o fotógrafo mundo afora.

Ele a chama de "mi amor" e ela, sempre direta, não corresponde o afeto e pergunta rispidamente se ele a espera há muito tempo. O homem (cujo nome não é revelado) explica que não quis acordá-la, pois percebera que estava cansada da viagem na noite anterior. Quer saber por onde chegou a Buenos Aires e ela diz que veio de Madrid - lugar onde estava antes de ir ao Porto, conforme revelou a José no webisódio anterior. Desse modo, Olívia omite sua passagem por Portugal antes de chegar à Argentina. Ele questiona a razão de ela não pedir que reservasse um hotel na capital espanhola, aparentemente desconfiado. Diz, ainda, que ela precisa parar um pouco, desfrutar os lugares sem pensar na hora do próximo vôo: "é um pecado você conhecer o mundo inteiro e não se dar tempo para conhecer cada lugar". Aparentemente, a efemeridade dela não incomoda apenas José.

Olívia gostaria de saber sobre o lugar onde estão, pergunta porque sempre voltam ali quando vão a Buenos Aires. Ele é enfático: “é um lugar de verdade. Com gente de verdade, que vem para ler o jornal e tomar um café, e nada mais". Novamente, os não-lugares (Augé, 1994) são evidenciados, dessa vez por meio de 
uma contraposição. Estão em um espaço simples, com identidade, longe da impessoalidade e sofisticação de hotéis em grande metrópoles. Os dois dão as mãos e a editora de moda revela que fica feliz por ele ter um lugar em Buenos Aires - ela gostaria de ter um "lugar em qualquer lugar".

Figura 11: Buenos Aires

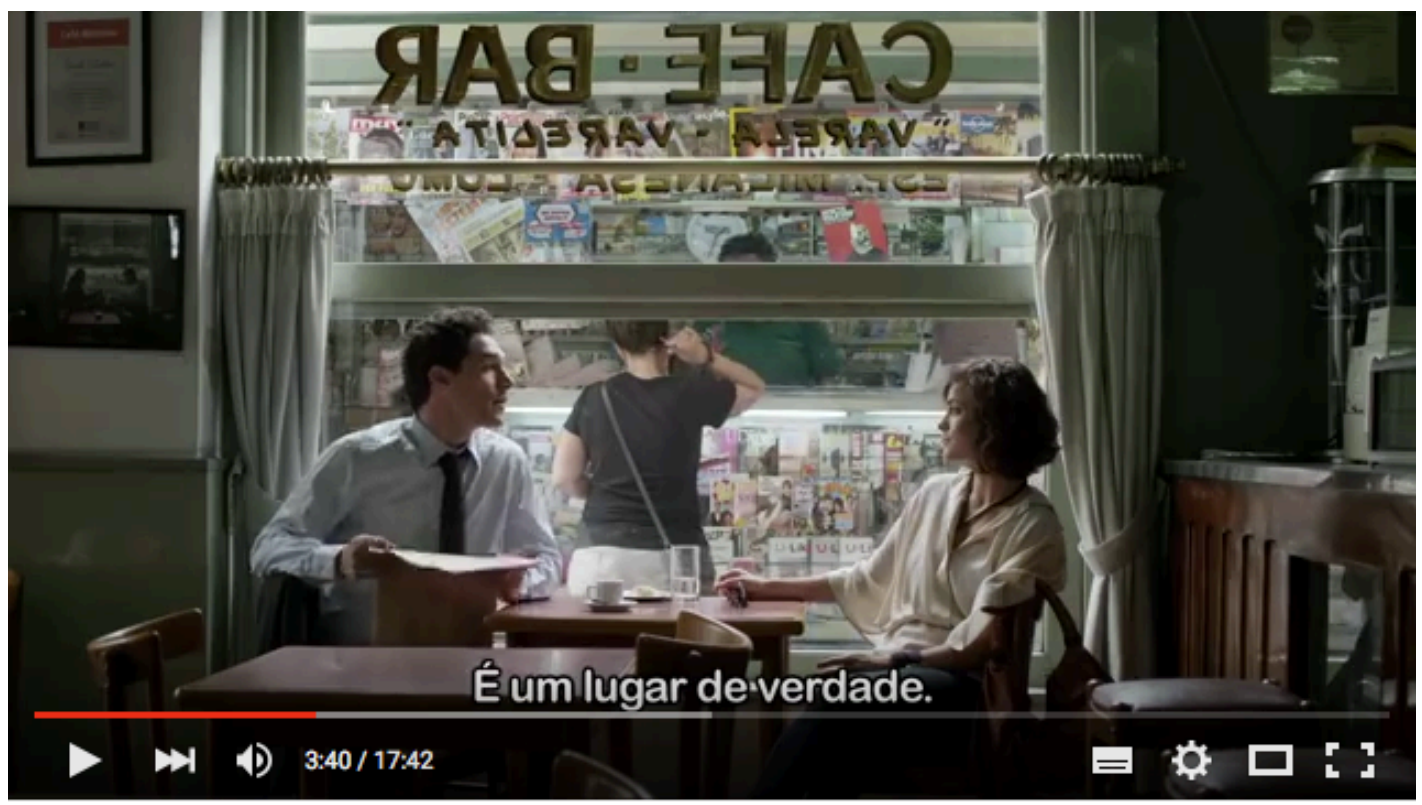

Olívia e o marido em Buenos Aires.

O homem sugere que façam uma viagem juntos e ela não se mostra animada, diz que o que mais quer é chegar em casa, cuja localização, no entanto, não é revelada ao público. Ele volta a perguntar por que ela veio de Madrid, já que estava em Londres e de lá há vôos diretos. Olívia diz que precisou passar um dia em Portugal e, questionada se havia encontrado amigos em comum do casal que moram lá, é evasiva e muda de assunto. Diz que foi a Buenos Aires apenas para encontrá-lo e que não quer discutir, pois está exausta. Ele insiste que ela passe uns dias em casa, que descanse, e ela é objetiva: "não posso".

Novamente, ele sugere que façam uma viagem juntos, que cancelem suas agendas por uma semana e fiquem só os dois. A princípio, a proposta não é endossada ou rejeitada por Olívia, que fica em silêncio. Depois de refletir um pouco, ela conclui que precisa ir para casa. Ele diz rispidamente que é bom que ao menos tenha essa certeza, alguma certeza. Ao retrucar que o homem dificulta as coisas agindo desse jeito, ele estoura e vocifera: "o que dificulta as coisas de verdade é o seu esforço patético de tentar manter o controle quando está claro que 
você não faz ideia de onde quer estar nos próximos cinco minutos".

Novamente, a necessidade de controle de Olívia é evidenciada. Apesar de seus esforços, a situação montada no Varela Varelita não está mais em suas mãos. Ela se sente culpada pelo romance com José e é acusada de ter ido encontrar o homem com o qual agora toma um café apenas para se certificar de que ele estaria disponível, da maneira como ela o deixou, e partir em seguida.

A necessidade de controle de Olívia continua tematizando o diálogo. Ele diz que ela fica em pânico ao atrelar a sua vida à vida de outra pessoa. Que ela se afasta e acha que deveria ir sozinha para casa, sozinha para se dar conta de que não haveria ninguém ali com quem pudesse contar. Que os poucos amigos que atenderiam suas ligações não poderiam conversar com ela a menos que fossem atualizados do que se passou no último ano de sua vida. Ou seja, Olívia tem laços fracos com as pessoas, o relacionamento que constrói com José, ao que parece, é um padrão em sua vida.

Figura 12: Varela Varelita, um "Iugar de verdade"

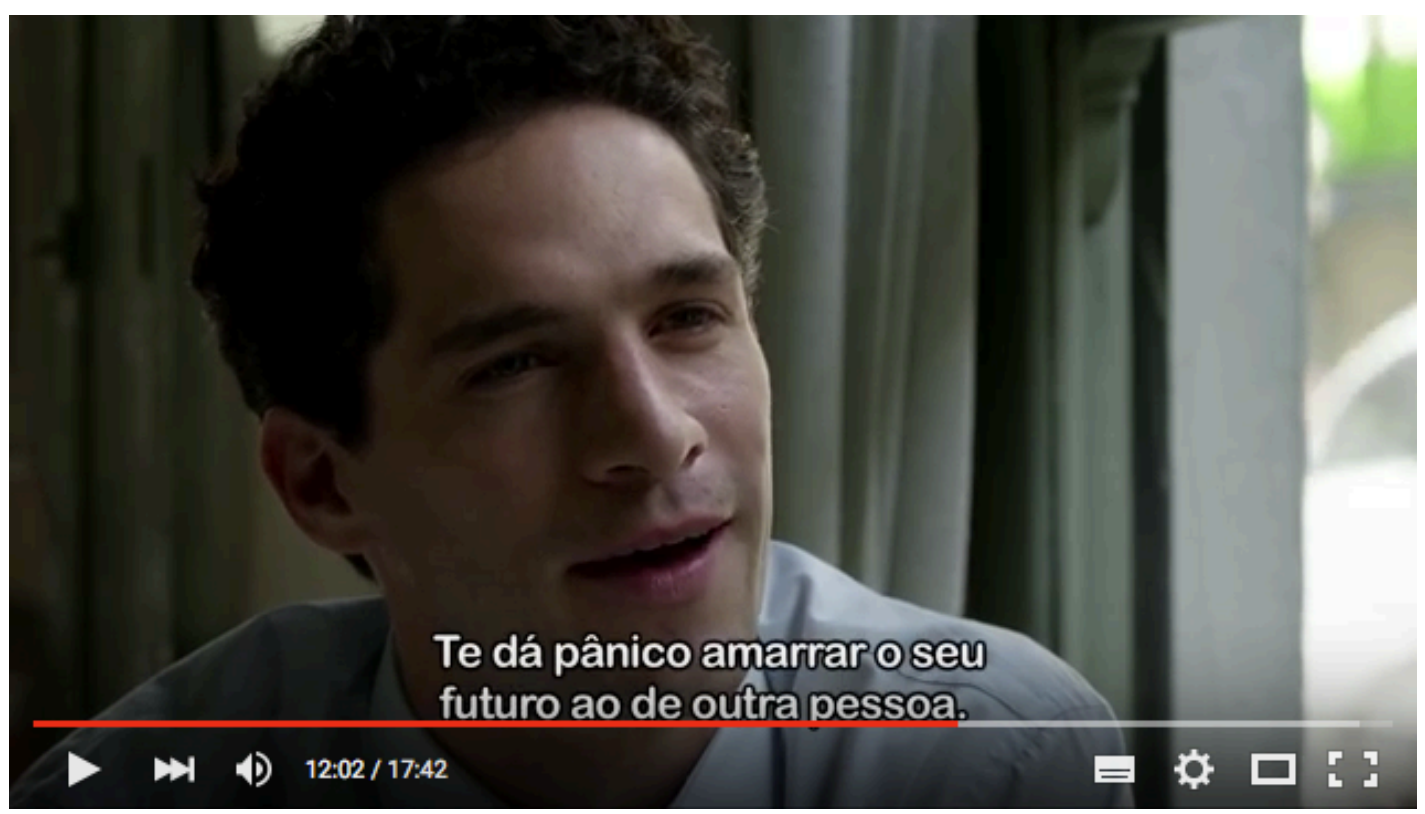

Marido de Olívia no Varela Varelita.

Apesar de não se saber até agora onde moram, nesse ponto o público entende que o homem e Olívia têm um lar em comum. São casados, e ele fala que não pode jogar esse jogo de cinismo que permitiria que continuassem assim. Ele sabe do que está acontecendo, apenas ainda não revelou. Dá voltas, acusa subliminarmente e desarma totalmente a editora de moda. Ela foi encontrá-lo e 
tenta agir normalmente apenas para não decidir o que fazer de sua vida. Para ganhar tempo, assim como faz com José, e não definir onde ou com quem gostaria de estar.

Abruptamente, o homem pede a conta. Diante do silêncio perplexo de Olívia, questiona se prefere perguntar o que está havendo e remoer o mar de detalhes que viria, ou simplesmente não saber de nada sobre, finalmente ele é claro, "esse cara com quem você tem saído". Vai mais fundo e complementa que supõe que seja apenas um, insinuando que ela tenha vários amantes espalhados pelo mundo.

Paga a conta, dizendo que o esforço que ela faz para dissimular é patético, que para ele está muito clara sua vontade de partir enquanto estão juntos. Por fim, pede desculpas, pois pegou o celular dela por engano ao sair do quarto pela manhã agora sabemos o que Olívia procurava ao acordar. Ela pergunta se ele mexeu no aparelho e recebe uma negativa: "não necessito de detalhes". O homem parte e a deixa sozinha.

- $\quad$ Latitudes - $8^{\circ}$ Destino - Istambul:

O oitavo episódio começa com uma sonora do primeiro, Olívia chamando em sussurros José pelo nome. Os dois estão se beijando na cama e a cena é intercalada por telas pretas com diálogos de episódios anteriores em off. A protagonista aparece mexendo no celular em várias cidades pelas quais passaram, revendo fotos dos quartos de hotéis onde estiveram e também as imagens dele registradas nas ruas do Porto. Desse modo, a história de encontros do casal é recontada a partir das fotos gravadas no aparelho. O novo enunciado, subjetivo, feito a partir das perspectivas pessoais de Olívia, remete a sentidos mais ligados ao afeto, sentimentais. 


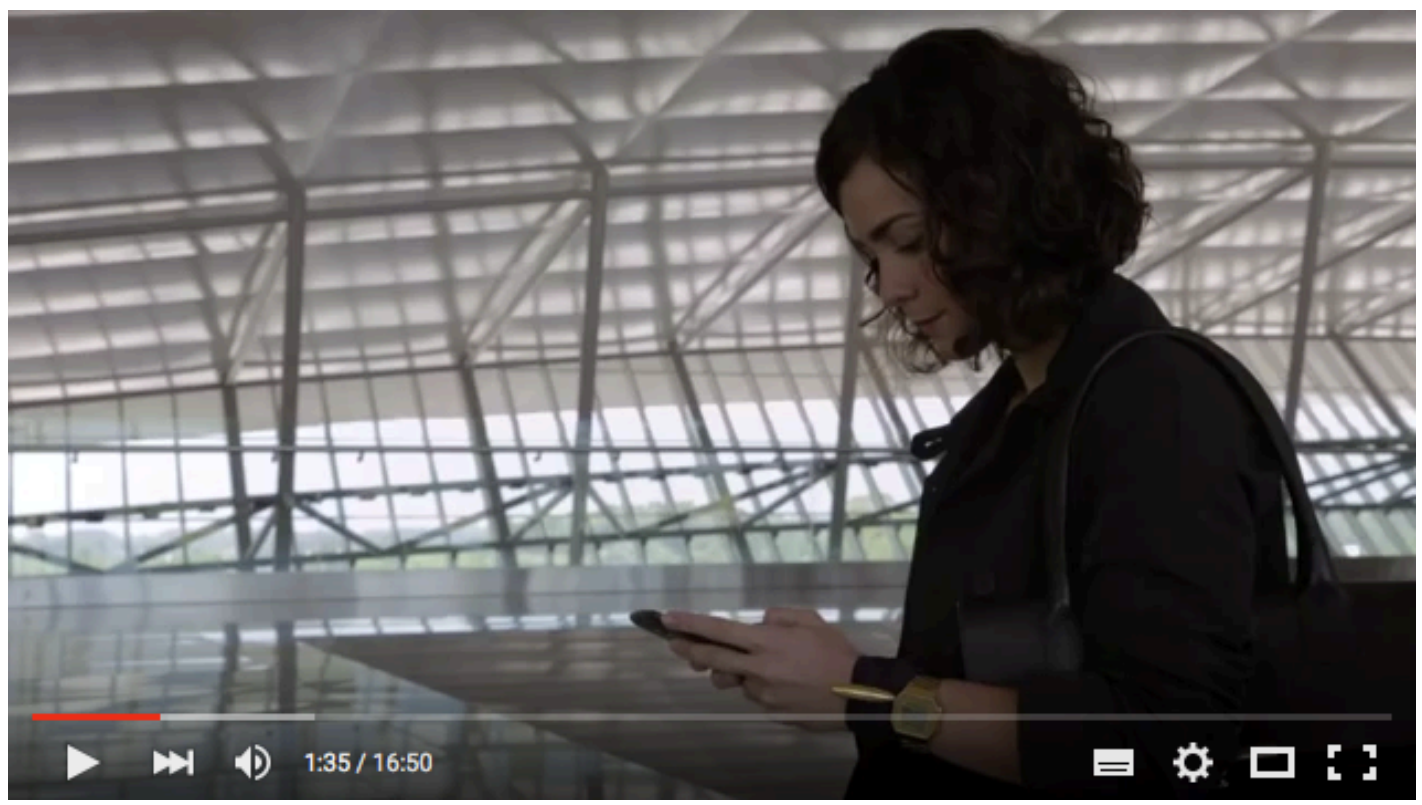

Olívia em uma estação ferroviária.

Em seguida, voltamos à sequência inicial, com os dois se beijando na cama. Passamos pelo desfile que ambientou o extra do episódio de Londres, ligações em Paris, até a trama retornar ao quarto de hotel onde estão agora. Olívia abre as cortinas, que revelam um dia ensolarado, enquanto José dorme na cama. Ao fundo ouve-se o Adham, chamado sonoro às orações diárias do islamismo. Estamos no Oriente. A protagonista sobe um lance de escadas e toma um café com vista para o centro de Istambul, revelando o destino final da história de amor que passou por oito países diferentes.

Estão no The House Hotel, um dos mais luxuosos da capital turca. Ela lembra de José Ignacio, única viagem que efetivamente fizeram juntos e não foi apenas um encontro com rápido encaixe de agendas. Nesse ponto, é apresentado um diálogo inédito em José Ignacio, que não havia aparecido no $4^{\circ}$ Destino. Enquanto conversam sobre as dificuldades da relação, ele reclamando da dificuldade de terem tempo juntos, Olívia é mostrada passeando sozinha por Istambul em imagens sem áudio, sonorizadas pelo diálogo.

Voltam ao quarto na Turquia: em meio às malas, roupas e acessórios espalhados, o fotógrafo acorda. Aparentemente, é uma ruptura na estrutura da narrativa, que direciona o espectador a um flashback que revela a estadia anterior de José na capital turca. Na cena que dá sequência à ação dramática, ele está já em um mercado de Istambul, foco em comidas e especiarias, entregando seu 
equipamento a uma assistente. Aparentemente, José estava ali a trabalho. Encontra Olívia em frente a um prédio histórico. Ele revela surpresa por vê-la ali, dessa vez ela que foi ao seu encontro. Após a discussão no último contato, diz que não sabe se tem ânimo para retomar de onde pararam e, provocativo, pergunta se há um táxi ou avião esperando por ela.

Ele a convida para jantar mais tarde e ela aceita, mas diz que vai precisar das chaves do quarto onde ele está hospedado - veio sem reservar hotel. Nesse momento, a imagem abre e vemos que Olívia está ali com as suas malas - sem aviso prévio, voltamos um pouco na trama para o momento em que se encontraram na Turquia. José recebe uma ligação e precisa voltar ao trabalho.

Voltamos para o quarto, na manhã em que acordaram juntos e, finalmente, saem para caminhar pela cidade. Estão em uma medina, bem identificada pelos mercados característicos e pelos templos. Voltam ao hotel, novas inserções mercadológicas, ele toma uma Heineken e há um produto Gillette no banheiro. Um celular toca e a cena é seguida pelos dois falando ao telefone, ele em português e ela em inglês, tratando de assuntos profissionais. Ele diz ter problemas no trabalho, a locação que usariam caiu e provavelmente terá que fotografar em outra cidade. Simbolicamente, invertem os papéis - dessa vez José precisará partir. Alguém bate à porta chamando por ele, que não responde e apaga a luz do quarto para pensarem que não há ninguém ali. Em seguida, no entanto, atende ao chamado - apesar dessa inesperada mudança, ele se submete, ele quer ficar com ela.

Voltam às ruas e, quando estão em clima de romance, o celular do fotógrafo toca novamente. Mais uma vez, assuntos do trabalho. Ela pede que não atenda, mas ele o faz mesmo assim. Ao desligar, José lamenta que terá mesmo que partir, e pergunta para onde Olívia irá depois dali. Surpreendentemente, ela responde: "para casa”. Ele fica perplexo e ela revela que isso é uma coisa boa. O fotógrafo protesta, não quer mais esperas intermináveis pelo próximo encontro e é interrompido por um beijo inesperado dela.

O celular toca novamente, aparentemente o chamado para o trabalho é inadiável - já estão recolhendo as coisas dele no quarto do hotel. Os dois conconrdam em agendar o próximo encontro, mas têm dificuldades: ele passará o mês viajando e ela fará o mesmo nos trinta dias seguintes, em semanas de moda por vários países. Continuam conversando, os dois têm muito o que resolver "em casa", 
mas o celular dele não para de vibrar. Olívia não parece incomodada com a situação, inclusive o apressa, dizendo que está atrasado.

Despedem-se e seguem em direções opostas. Som de mensagem no celular de José; ele olha, sorri e segue seu caminho. Aparentemente, uma referência ao final do episódio em Londres, quando a mesma coisa acontece em um parque. Sozinha, Olívia contempla a vista de Istambul de um barco, com o Adham ao fundo, no fim do dia. Diferentemente do comum para os fins dos episódios, sempre com conflitos e despedidas, ela sorri. Está feliz.

A narrativa termina, portanto, sem dar grandes certezas às suas audiências. Houve uma ruptura no comportamento de Olívia que pode indicar a possibilidade da atenuação dos problemas do casal. Mas essa resposta não é trazida objetivamente pela trama, e nossas viagens com José e Olívia se encerram, até o momento, na Turquia. A partir das andanças do casal pelo mundo, elaboramos esse mapa que sintetiza as cidades por onde Olívia e José passaram durante o desenvolvimento de Latitudes:

Figura 14: Mapa de Destinos em Latitudes

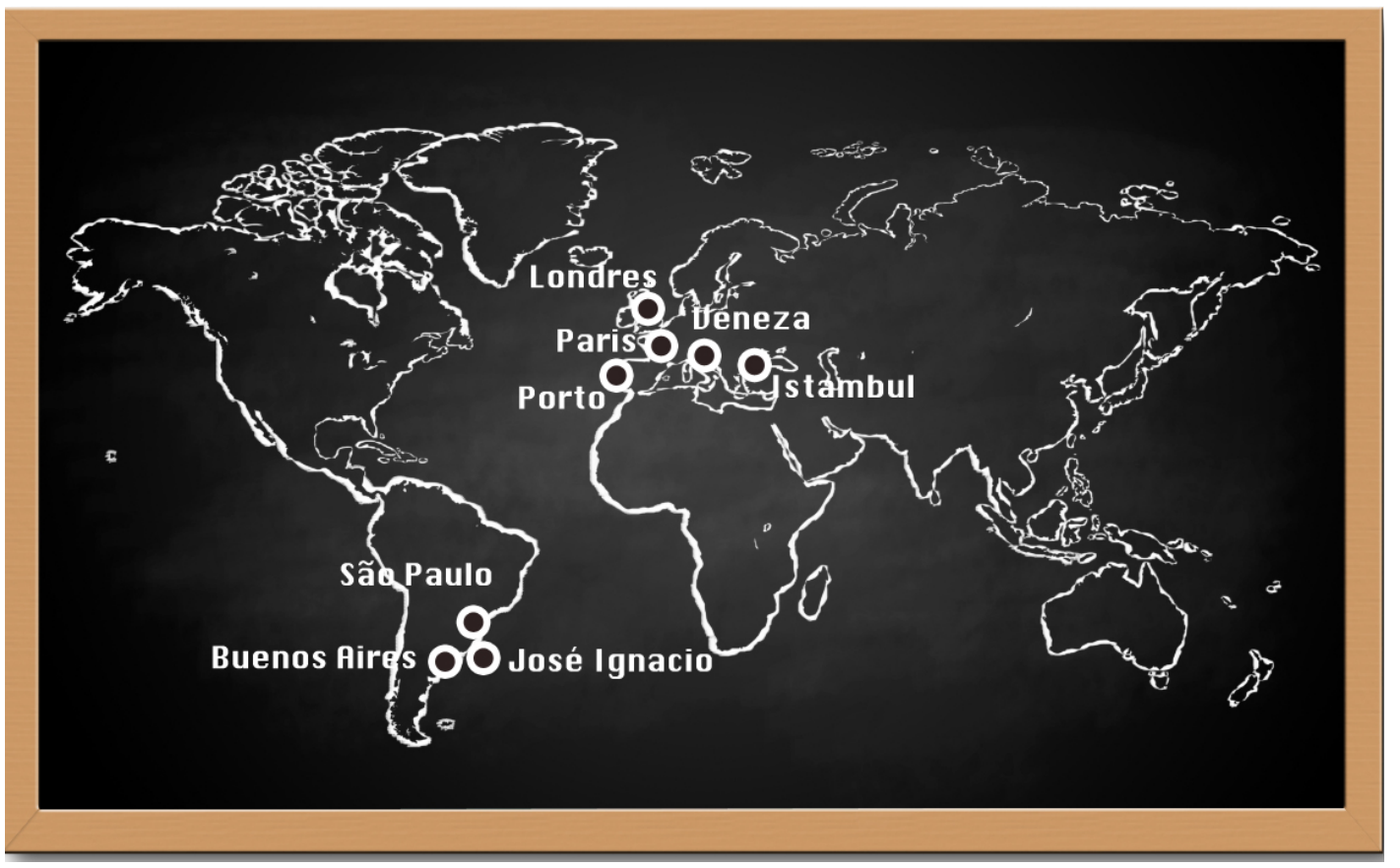

A partir do mapa, é interessante notar alguns significados que podem não ficar claros durante a fruição seriada de Latitudes, mas produzem sentidos importantes para a compreensão da obra. Olívia e José se conhecem e começam a 
se relacionar em Paris, capital mundial do romance e dos casais apaixonados. Esse fato pode se configurar como uma "promessa" de felicidade, certa estabilidade da narrativa que vai sendo gradativamente quebrada nos episódios (ou cidades) posteriores.

O destino seguinte é Londres, capital de uma das principais economias da Europa, onde os dois se encontram "acidentalmente" enquanto cumprem suas agendas de trabalho. Não por acaso, ali são reforçados alguns aspectos importantes à narrativa, como o comprometimento profissional de José e Olívia, o caráter cosmopolita e a sofisticação e requinte dos dois - seja pelo gosto por bebidas ou pelos hotéis onde se hospedam. A passagem pela Inglaterra é marcada por um conteúdo extra, que exibe Olívia trabalhando durante a London Fashion Week.

O terceiro encontro do casal acontece em Veneza, cidade que é muito marcada na obra pela sua ambientação exótica e ligada ao oriente. Dessa vez, apenas Olívia está lá a trabalho e José teria se dirigido à cidade apenas para encontrá-la. Essa dinâmica marca o primeiro grande conflito entre os dois em Latitudes, exatamente pela efemeridade dos encontros e pela constante urgência de Olívia em partir.

O conflito estabelecido em Veneza se desdobra na promessa de um próximo encontro sem pressa e sem um vôo marcado para o dia seguinte. Partem, então, para José Ignacio, primeiro lugar fora da Europa apresentado na obra. Também é a primeira vez que estão fora de um centro urbano, em meio a uma paisagem bucólica e isolada. Apesar da intenção inicial de resolverem seus problemas e terem um tempo juntos, o conflito é acentuado no Uruguai. Talvez isso se deva ao fato de os dois estarem perto de casa, o que nos leva ao próximo destino.

Em São Paulo, pela primeira vez a narrativa se passa fora de um hotel. José está em casa, onde encontra a namorada, e o episódio inteiro consiste em um diálogo entre os dois, no qual o fotógrafo revela o romance que tem com Olívia e termina o relacionamento com Aline. Apesar de os atritos pessoais serem uma constante em Latitudes, é interessante perceber que o arco dramático estabelecido no Brasil começa e termina no mesmo episódio, com a resolução do conflito.

No Porto, destino seguinte, a narrativa passa por uma transformação significativa: pela primeira vez, Olívia vai ao encontro de José, que estava realizando um compromisso profissional em Portugal. Ela mudara o voo que a levaria de volta à Argentina para encontrar o fotógrafo e passar algumas horas com 
ele. Já em Buenos Aires, Olívia é confrontada com o marido, que descobre sobre seu romance extraconjugal. Novamente, o arco narrativo começa e termina no mesmo episódio. Também é aqui que a questão dos não-lugares e da fluidez dos relacionamentos estabelecidos pelos protagonistas fica mais gritante.

Por fim, encontram-se em Istambul, cidade marcada pelo islamismo e, como Veneza, pela ambientação exótica. É interessante notar que o derradeiro destino de Olívia e José é o mais longe que estiveram de casa durante o desenvolvimento da narrativa, o que nos leva a pensar que para que o relacionamento entre os dois dê certo, é necessária essa ruptura com o lar e com o familiar. Mais uma vez, o episódio (e portanto, a história) termina com uma despedida; ela não é, no entanto, antecedida por brigas e conflitos, mas aceita como parte integrante da maneira pela qual o casal quer/pode se relacionar.

A sequência das cidades por onde Olívia e José passam permanece inalterada entre as plataformas pelas quais Latitudes circula. Como colocamos anteriormente, o projeto transmídia foi disponibilizado no YouTube e veiculado na televisão e nas salas de cinema. No próximo capítulo, faremos uma análise da conjuntura da produção audiovisual brasileira, que está marcada pelo espalhamento dos conteúdos em múltiplas plataformas, assim como ocorre em Latitudes. 


\section{CAPÍTULO 4: A PRODUÇÃO FICCIONAL EM TEMPO DE TRANSMIDIAÇÃO}

A transmidiação é um processo complexo que envolve um modelo de produção que se caracteriza tanto pela distribuição de conteúdos em mídias distintas quanto - e talvez principalmente - pelo aumento da possibilidade de participação e interação dos consumidores desses conteúdos por meio das mídias digitais. Jenkins $(2008$, p. 47) destaca que esse processo tem como característica principal a existência de uma prática social que depende da "participação ativa de comunidades de conhecimento". Assim, a lógica de produção e distribuição multiplataforma ganha força principalmente com a cultura participativa ${ }^{12}$, conforme destaca Fechine (2014). Compreendendo que esse modelo se configura na atualidade como uma tendência, é importante verificar de que maneira ele opera em várias esferas da Comunicação: publicidade, jornalismo e teledramaturgia, por exemplo.

Nessa perspectiva, tornam-se cada vez mais comuns as narrativas transmídia (Jenkins, 2008), que se desenvolvem a partir de múltiplos canais de mídia para a constituição do universo narrativo. Desse modo, os títulos, muitas vezes, convertem-se em marcas (ou franquias de mídia, conforme trataremos adiante) e convidam os fãs a compartilharem suas experiências com os conteúdos e desenvolverem suas próprias histórias. Apesar de fortemente marcadas pela interação com as audiências, as narrativas transmídia também podem se caracterizar como investimentos no âmbito da produção, e é nesse polo que centraremos esforços em nossa análise.

A fim de contextualizar a realização ficcional nesse cenário, o presente capítulo trata sobre as transformações técnico-culturais na produção, distribuição e consumo de televisão em tempos de expansão das mídias digitais. Observamos que, gradativamente, a grande indústria de mídia abre espaço para modelos streaming de distribuição e consumo, estabelecendo relações cada vez mais íntimas entre a televisão e a internet.

Também notamos influências importantes na Lei 12.485 (2011), que será detalhada adiante, no crescimento da produção de conteúdos independentes tanto

\footnotetext{
${ }^{12}$ Shirky (2011) define a cultura participativa como uma nova dinâmica de produção orientada por processos colaborativos, desenvolvida por pessoas "comuns" (amadores), que passam a intervir na realização dos conteúdos "oficiais" e gerar seus próprios conteúdos independentes.
} 
para a TV paga quanto para a internet. Nesse cenário, as experimentações de produtos transmídia ganham novas possibilidades e tornam-se mais viáveis, o que potencializa o surgimento de novos formatos e novos modelos de realização, distribuição e consumo da ficção audiovisual brasileira como discutimos a seguir.

\subsection{Grade de programação: fluxo e arquivo}

Gostaríamos de iniciar a discussão identificando a distribuição de conteúdos entre várias telas como tendência do atual momento na produção de conteúdos audiovisuais denotando a cultura da convergência (Jenkins, 2008). No cenário audiovisual, os produtos e produtores têm de se adaptar a novos modelos de distribuição que não mais centralizem a programação exclusivamente na TV (ou mesmo no cinema). Sintonizada com essa nova configuração de produção, distribuição e consumo, Latitudes é uma narrativa concebida para circular em três plataformas principais: YouTube, televisão e cinema. Como foi dito anteriormente, a versão online é composta por oito episódios (que foram ao ar antes da série televisionada e do longa metragem) e concentram todo o conteúdo ficcional exibido nas outras plataformas. Com Alice Braga (Olívia) e Daniel de Oliveira (José) como protagonistas, Latitudes conta a história de encontros e desencontros do casal ao redor do mundo, sendo cada episódio nas versões seriadas (YouTube e televisão) ambientado em uma cidade diferente.

A versão para o cinema, resultado da montagem dos episódios em um longa metragem, foi distribuída pela O2 Play e estreou em fevereiro de 2014 (Latitudes já estava disponível no YouTube desde setembro de 2013 e já havia sido exibida na TV paga, pelo canal TNT, um pouco depois - mas ainda no mesmo período, entre 02 setembro e 21 outubro de 2013).

Nesse ponto, trazemos à luz do debate os conceitos de fluxo e arquivo, que definem modelos distintos de distribuição de conteúdos (Fiske, 1987). Entende-se o fluxo como a programação broadcast, transmitida incessantemente na televisão tradicional. Já o arquivo se refere à programação disponibilizada on demand, que é acessada de acordo com a vontade e a necessidade da audiência. Cannito (2010, p. 53) esclarece que "o arquivo não é, portanto, melhor do que o fluxo. Nem o contrário. São estéticas diferentes e o público, a cada momento, opta por utilizar uma delas". Ao disponibilizar uma websérie no YouTube e uma série televisionada, 
Latitudes joga com as duas possibilidades, apontando uma convergência de conteúdos e uma experimentação inédita na produção ficcional brasileira.

$\mathrm{O}$ interessante de perceber no modelo de narrativa estabelecido em Latitudes é sua centralidade na internet. Além de ter sido disponibilizada nesta última antes das outras plataformas, a versão online concentra a integralidade ficcional da obra: ela é "autossuficiente", no sentido de não ser necessário que as audiências recorram a outras plataformas para total compreensão da trama. A televisão, por sua vez, traz o mesmo conteúdo disponível na internet, mas com sequências extras de produção, revelando detalhes da feitura da obra, em uma espécie de metanarrativa. Essas cenas extra-diegéticas serão detalhadas e categorizadas nas discussões sobre formatos e gêneros do Capítulo 6, quando se aponta que representam novas ferramentas oferecidas no âmbito da produção para interpretações do público, como ensaios, leituras dramáticas e descrição dos sentimentos das personagens.

Adotando esse modelo de produção híbrido, Latitudes contou fortemente com as redes sociais para divulgação e propagação de seus conteúdos. Além disso, uma plataforma específica foi central na distribuição da obra: o YouTube. Essa rede se insere no que Castells (2009, p. 65) define como mass self-communication, ou "a forma de comunicação que surgiu com a Web 2.0 e 3.0 e que corresponde à proliferação de espaços sociais na internet nos quais as pessas se expressas e que leva a internet a praticamente todas as facetas da vida social".

Dessa forma, as novas tecnologias difundidas a partir da internet moldam novos modos de produção de conteúdos de entretenimento, que circulam entre as mídias ditas tradicionais e estão cada vez mais ligadas a múltiplos dispositivos. " $\mathrm{O}$ que a Internet faz é processar a virtualidade e transformá-la em nossa realidade, constituindo a sociedade em rede ${ }^{13}$, que é a sociedade em que vivemos" (CASTELLS, 2003, p. 287). Esse fenômeno insere Latitudes em um contexto de arquivo (YouTube), mas sem abrir mão do fluxo televisivo:

Um modelo baseado puramente em produtores e público não pode explicar de forma adequada os diversos pontos de interseção entre as várias partes interessadas nesses sistemas de valor híbridos. Yochai Benkler afirma em seu livro The wealth of networks (2006) que o surgimento das plataformas Web 2.0

\footnotetext{
${ }^{13}$ Gostaríamos de enfatizar a relevância para as discussões neste trabalho do conceito de sociedade em rede e de suas implicações para os modos de recepção na sociedade atual.
} 
resulta em uma ecologia de mídia, na qual os produtores de mídia comercial, amadora, sem fins lucrativos, governamental e educacional interagem de formas cada vez mais complexas, muitas vezes empregando os mesmos canais de mídia (e textos particulares) para propósitos muito diferentes. Por exemplo, com barreiras relativamente pequenas de acesso, o YouTube apoia muitos tipos de usuários, que variam desde participantes casuais até produtores independentes, instituições culturais, partidos políticos, produtores profissionais e uma miríade de categorias entre eles. De fato, o sucesso do site se deve, em parte, a certa flexibilidade que o torna acessível e valioso para essa base de usuários diversificada. Com poucos limites reais sobre o que pode ser enviado via upload para o site (com exceção das restrições em torno de material pornográfico, violação de direitos autorais e algumas categorias que infringem as "normas das comunidades"), o YouTube é uma plataforma que oferece um alcance potencialmente grande para quase todos os que chegam. $\mathrm{O}$ site incentiva os usuários a pensar em si mesmos como uma espécie de moeda, com os participantes ganhando prestígio social através do número de visitas que atraem (JENKINS, FORD e GREEN, 2014, p. 126).

Consideramos que o modelo adotado por Latitudes assumiu a posição de uma experimentação narrativa e estética na produção ficcional brasileira, representante de uma nova tendência de distribuição e consumo. O que ainda é comum observar em projetos transmídia no país é a centralidade narrativa na televisão ou no cinema, sendo legada à internet a função de trazer conteúdos extras sobre uma obra "principal", que está offline. O que se vê em Latitudes, no entanto, é a construção de uma narrativa transmídia que deposita grande parte de suas fichas na internet, em uma plataforma que por natureza serve como repositório de conteúdos e os disponibiliza on demand: o YouTube. O que se percebe, portanto, é a inclinação a:

(...) abandonar o telecentrismo e manter um olho observando a evolução de outros nichos próximos à televisão, como, por exemplo, os jogos, as interfaces web e os dispositivos móveis. (SCOLARI, 2014, p. 47)

Esse modelo refuta primordialmente algo extremamente tradicional na TV como a conhecemos até agora, o que tem gerado grande debate acerca dos rumos da televisão na contemporaneidade: a grade de programação, conforme já comentamos anteriormente. Disponibilizando sua narrativa principal online, Latitudes quebra a necessidade de a audiência acompanhar a obra de acordo com os dias e horários nos quais ela é exibida na mídia tradicional. O conteúdo, entretanto, constituído por 
uma narrativa linear e episódica, não deixa de ser televisivo só por estar em outro suporte.

Posto isso, consideramos que Latitudes inaugura, no Brasil, um formato que aponta para o crescimento da produção transmídia, como consequência desse novo cenário, privilegiando a internet em seus processos de distribuição. Talvez ela se mostre como o resultado de uma adaptação que as obras televisivas tradicionais precisam fazer para atender a novas demandas de uma audiência cada vez mais conectada e com uma imensidão de conteúdos disponíveis em inúmeras plataformas online; fato que propicia a esse público mais possibilidades de escolha gerando, por sua vez, para o produtor, a necessidade de ser mais criativo para se destacar entre tantos realizadores e conseguir atenção dessas audiências cada vez mais fragmentadas e fugidias. Nesse sentido, cabe destacar que faz alguns anos que as produções de ficção nacionais dialogam com plataformas online (Fechine, 2014), mas nunca se tinha observado a centralidade delas nas narrativas de grandes projetos.

A aparição de novas espécies no ecossistema midiático, tais como jogos de vídeo ou a web, estão mudando o ambiente, obrigando as velhas espécies (televisão, imprensa, rádio etc.) a adaptar-se para sobreviver. Por outro lado, estamos testemunhando o nascimento de espécies bastardas, ou seja, meios híbridos que adotam ou simulam gramáticas e narrativas de outros meios (SCOLARI, 2014, p. 49).

Latitudes se configura, desse modo, como uma "obra bastarda" que desvela novos caminhos da produção audiovisual ficcional brasileira, associando gramáticas e narrativas televisuais ao YouTube e trazendo para a televisão conteúdos que pertenceriam tradicionalmente às plataformas online - os já citados conteúdos extras de produção, que abordaremos posteriormente.

Dado esse contexto, percebe-se que a televisão vive um processo de adaptação para sobrevivência. Ela precisa se espalhar entre várias telas e atender a públicos cada vez mais segmentados. Sobre o atual cenário da TV, Orozco esclarece que:

(...) temos uma TV em transição, que está deixando de ser uma tela dominante para ser uma tela a mais entre muitas outras que, rotineiramente, atingem amplos setores da audiência. Nesse sentido, a TV compete, e tem competido, principalmente, por meio de canais pagos que se especializam para satisfazer os gostos particulares do público" (OROZCO, 2014, p. 103). 
Muito se fala sobre a "morte" da televisão, em uma predição de seu fim inevitável. Percebemos, entretanto, opiniões diversas entre os autores e tendemos a nos alinhar aos que defendem a transformação da TV e sua inserção em novos cenários, como a hipertelevisão, que, segundo Scolari (2014), privilegia os conteúdos gravados e sob demanda no lugar da grade de programação.

Esse fenômeno tem influência direta nas e das audiências, que estão cada vez mais fragmentadas, dividindo-se entre um número crescente de mídias, plataformas e canais, que lhes propicia a possibilidade de fruir conteúdos mais especializados. O avanço tecnológico, que caminha ao lado dessas novas experiências culturais relacionadas à televisão, tem influência direta nos modelos de distribuição que vêm surgindo. A popularização de plataformas on demand cria novas formas de recepção e participação mais individualizadas (Machado; Vélez, 2014). Nesse contexto, não apenas a audiência, mas principalmente os produtores de conteúdos de televisão estão sendo desafiados a inovar em seus processos que se mostram defasados frente ao novo mundo de possibilidades no qual se encontram, mostrando um cenário dinâmico em que

A televisão, no entanto, ainda domina como um modelo de produção, distribuição e recepção - um modelo que muda ao longo do tempo para uma versão mais móvel em relação à norma dominante" (MILLER, 2014, p. 93).

A morte da televisão não está decretada. De acordo com dados de Lopes e Orozco (2014) no Anuário do Observatório Ibero-americano da Ficção Televisiva, cerca de 60 milhões de pessoas acessam conteúdos da televisão pela internet e já há aproximadamente 4,4 milhões de usuários de serviços on demand no Brasil. Talvez por isso Latitudes, mesmo concentrando esforços na internet, não abra mão da exibição televisiva e dos cinemas. É um jogo de poder no qual a as mídias tradicionais ainda são big players e não podem ser deixadas de lado, principalmente no cenário latino-americano.

\subsection{Aumento da produção audiovisual nacional: a lei do cabo}

A produção audiovisual de um país não pode ser compreendida como mera expressão cultural, ou, ainda, como simples produção que atende aos desejos de um mercado. É, na verdade, uma simbiose entre as duas categorias, principalmente 
quando se leva em conta o Brasil, onde as ficções televisivas - sobretudo as telenovelas - estabelecem uma narrativa sobre a nação (LOPES, 2003) e ao mesmo tempo são produzidas verticalmente e comercializadas no cenário internacional. Por outro lado, há uma gama de produções independentes que são distribuídas principalmente pela internet e canais da TV paga. Ficam, portanto, fora do hall de megaproduções da indústria nacional de entretenimento.

Sob essa perspectiva, é possível entender o cenário de realização audiovisual como palco de disputas e conflitos, onde produções de baixo orçamento competem com grandes veículos de comunicação e títulos internacionais ganham espaço nas grades horárias em detrimento do conteúdo local. De acordo com o Relatório Mundial da Organização das Nações Unidas para educação, a ciência e a cultura (UNESCO) de 2009 (apud Sousa, 2014), em 2006, as indústrias culturais responderam por 7\% do PIB mundial e renderam cerca de US\$1.3 trillhão. Martel (2012) fala sobre dois modelos claros e estratégicos de dominação: o soft power e o hard power. Enquanto o último se refere ao poderio econômico, industrial e militar de um grupo ou nação, o primeiro, segundo o autor, ganha força na política do mundo globalizado. É, portanto, uma dominação que acontece por meio da cultura, influenciando gosto, consumo e valores. A partir do crescimento da indústria criativa ao redor do mundo, é possível perceber a importância do soft power na economia global e como instrumento de influência e poder.

Nesse contexto televisivo e cinematográfico globalizado e dominado em certa medida pelos produtos estadunidenses (Martel, 2012), mecanismos de protecionismo da produção cultural nacional são comuns ao redor do mundo. Existem várias maneiras de "privilegiar" a realização local, desde o investimento em emissoras públicas, até a exigência de transmissão de tipos específicos de conteúdos usando como critério a sua origem nacional. Esse mecanismo é conhecido como "cota de tela", e é relativamente comum no cenário internacional, sendo adotado, por exemplo, na Coreia do Sul, Espanha e Itália e compreendido desde 1947, pelo General Agreement on Tariffs and Trade ${ }^{14}$ (GATT), como uma medida legítima de políticas culturais nacionais (Sousa, 2014).

\footnotetext{
${ }^{14} \mathrm{O}$ General Agreement on Tariffs and Trade (ou Acordo Geral de Tarifas e Comércio em português) foi um tratado assinado por 23 países fundadores, que buscou regulamentar as relações comerciais internacionais. O Acordo está na base da criação da Organização Mundial do Comércio e compreende as produções audiovisuais a partir de seu entendimento como um híbrido entre aspectos econômicos e culturais, conforme explicado anteriormente.
} 
Essa resolução do GAAT gerou polêmica no cenário internacional à época de sua implantação e jamais foi aceita pelos Estados Unidos, que a consideram um atentado à liberdade de expressão e circulação de informações. Do outro lado, países europeus defendiam a medida como legítima, alegando que protegiam suas produções do ostracismo e da consequente extinção contra uma massificação cultural liderada pelos EUA (Sousa, 2014).

Após muita disputa, em 2005 a UNESCO aprovou uma convenção sobre Proteção e Promoção da Diversidade das Expressões Culturais, que passou a direcionar a regulamentação desse tópico. Apesar de a convenção não cessar as polêmicas e discussões, ela passou a legitimar medidas de proteção de produções culturais nacionais e embasou o estabelecimento, no caso brasileiro, da lei de cotas de tela para a TV por assinatura.

Antes de falar da lei e de suas implicações, é interessante traçar um breve panorama técnico do cenário da televisão brasileira. Desde que foi estabelecida no Brasil, na década de 1950, a TV configura-se como um sistema de radiodifusão comercial privado, o que tem como consequência uma rede pública fraca nos dias atuais. Pouquíssimo regulada e sob essa lógica privada, a TV brasileira se tornou um cenário de hegemonia onde uma única emissora, a Globo, concentra grande poder político e econômico, além de mais de 50\% da audiência nacional (ou seja, todas as audiências das emissoras concorrentes somadas não alcançam os índices de penetração da Globo). Ao se falar em realização ficcional, é relevante dizer que somente a líder de audiência e duas outras emissoras (Record e SBT) produziram títulos exibidos pela TV aberta no Brasil durante os últimos anos (Lopes; Mungioli, 2011, 2012, 2013, 2014 e 2015).

Temos uma indústria televisiva brasileira na qual os grandes produtores são as próprias emissoras e, responsáveis, portanto, pela distribuição dos conteúdos que elas próprias realizam. Trocando em miúdos, isso representa uma conjuntura desfavorável à realização independente, que, além de lidar com a falta de recursos, se vê impossibilitada de "escoar" suas produções no mercado de mídias tradicional. Uma esperança despontou no horizonte quando, na década de 1990, a TV paga surgiu no Brasil. Apesar de o marco legal que regulamentou seu estabelecimento definir apenas a obrigatoriedade de uma emissora nacional compor a oferta de canais, a TV paga aparece como possibilidade de oportunidade aos produtores independentes, que em 1999 se organizaram e criaram a Associação Brasileira de 
Produtores Independentes (ABPI-TV).

Organizados nessa associação, os produtores passaram a exigir medidas de proteção aos conteúdos domésticos, o que possibilitou, nos anos 2000, que pela primeira vez na história brasileira os conteúdos televisivos também passassem a ser contemplados nas políticas nacionais audiovisuais, visto que, até então, somente o cinema era levado em conta nesse âmbito. Apesar de ter sido arquivado posteriormente, permitiu, além da organização dos produtores, que fossem abertos precedentes para se pensar em políticas públicas dos conteúdos televisivos nacionais.

Em 2004, o Ministério da Cultura apresentou o projeto de criação da Agência Nacional do Cinema e do Audiovisual (Ancinav), que regularia a TV, e não mais apenas o cinema, e criava regras relativas ao conteúdo televiso e à proteção contra Hollywood. Acusado de interferir em negócios privados e quebrar regras comerciais, o projeto foi arquivado pelo presidente Lula em 2005. (SOUSA, 2014, p. 7)

Esse contexto possibilitou que, em 2007, fosse colocado em discussão o Projeto de Lei 116 , que deu origem à Lei $12.485^{15}$ em vigor hoje. Conhecida como "Lei do Cabo" - a despeito de contemplar operadoras de TV paga via cabo, satélite ou fibra ótica -, a norma foi publicada no Diário Oficial em setembro de 2011 e tem três grandes focos de atuação: a) permitir que as corporações de telecomunicações possam oferecer o serviço de TV paga, como maneira de aumentar a concorrência e diminuir o valor do serviço cobrado ao consumidor; b) estabelecer, progressivamente, que a cada três canais estrangeiros ofertados nos pacotes assinados, um seja nacional; e c) estipular um aumento gradativo da obrigatoriedade de exibição de conteúdos nacionais nas emissoras, no seguinte modelo (Sousa, 2014):

- Ano 1 (2011): os canais devem exibir uma hora e dez minutos de programação nacional no horário nobre ${ }^{16}$ semanalmente, sendo metade dela realizada por produtoras independentes. Aqui, um em cada nove canais deve ser nacional.

- Ano 2 (2012): os canais devem exibir duas horas e vinte minutos de

\footnotetext{
${ }^{15}$ Link para a íntegra da Lei 12.485: www.planalto.gov.br/ccivil_03/_Ato20112014/2011/Lei/L12485.htm

${ }^{16}$ No Brasil, o horário nobre se estabelece entre as $18 \mathrm{~h}$ e meia-noite, tendo seu pico de audiência entre as $20 \mathrm{~h}$ e $23 \mathrm{~h}$.
} 
programação nacional no horário nobre semanalmente, sendo metade dela realizada por produtoras independentes. Aqui, um em cada seis canais deve ser nacional.

- Ano 3 (2013): os canais devem exibir três horas e trinta minutos de programação nacional no horário nobre semanalmente, sendo metade dela realizada por produtoras independentes. Aqui, finalmente, um em cada três canais componentes do pacote de assinaturas deve ser nacional.

Vale ressaltar que essa obrigatoriedade recai sobre canais qualificados, que são compreendidos como emissoras que exibem prioritariamente filmes, séries, animações e documentários. De acordo com o capítulo 4 da Instrução Normativa 100 da Agência Nacional do Cinema (ANCINE), os espaços qualificados são os seguintes: "espaço total do canal de programação, excluindo-se conteúdos religiosos ou políticos, manifestações e eventos esportivos, concursos, publicidade, televendas, infomerciais, jogos eletrônicos, propaganda política obrigatória, conteúdo audiovisual veiculado em horário eleitoral gratuito, conteúdos jornalísticos e programas de auditório ancorados por apresentador"17.

Também é importante definir do que se fala na exigência de que metade do conteúdo seja realizada por produtoras independentes. Quais são essas produtoras? Segundo a lei 12.485, são contempladas sob essa categoria as produtoras que:

a) não são controladoras, controladas ou coligadas a programadoras, empacotadoras, distribuidoras ou concessionárias de serviço de radiodifusão de sons e imagens;

b) não estão vinculadas a instrumentos que, direta ou indiretamente, confiram ou visem conferir a sócios minoritários, quando estes forem programadoras, empacotadoras, distribuidoras ou concessionárias de serviços de radiodifusão de sons e imagens, direito de veto comercial ou qualquer tipo de interferência comercial sobre os conteúdos produzidos;

c) não mantêm vínculos de exclusividade que as impeçam de produzir ou comercializar para terceiros os conteúdos audiovisuais por elas produzidos ${ }^{18}$.

\footnotetext{
${ }^{17}$ Fonte: INSTRUÇÃO NORMATIVA (ANCINE) n ${ }^{\text {o }}$ 100, de 29 de maio de 2012.

${ }^{18}$ Fonte: site ANCINE - http://www.ancine.gov.br/faq-lei-da-tv-paga
} 
Percebe-se, portanto, que as medidas, além de priorizarem a programação nacional, estimulam o surgimento e crescimento de produções independentes de realizadores que sempre estiveram fora do oligopólio de mídia estabelecido historicamente no Brasil. De acordo com Marco Altberg, presidente da ABPI-TV, o novo cenário resulta de uma evolução natural do mercado, que leva à implementação de políticas públicas que favoreçam a produção audiovisual independente $^{19}$. O impacto pode ser observado pelo quadro abaixo, que mostra o crescimento do número de produtoras associadas entre os anos de 2011 e 2014.

Gráfico 3: Crescimento de associados à ABPI-TV

Base de crescimento dos associados ABPITV (2011 a 2014)

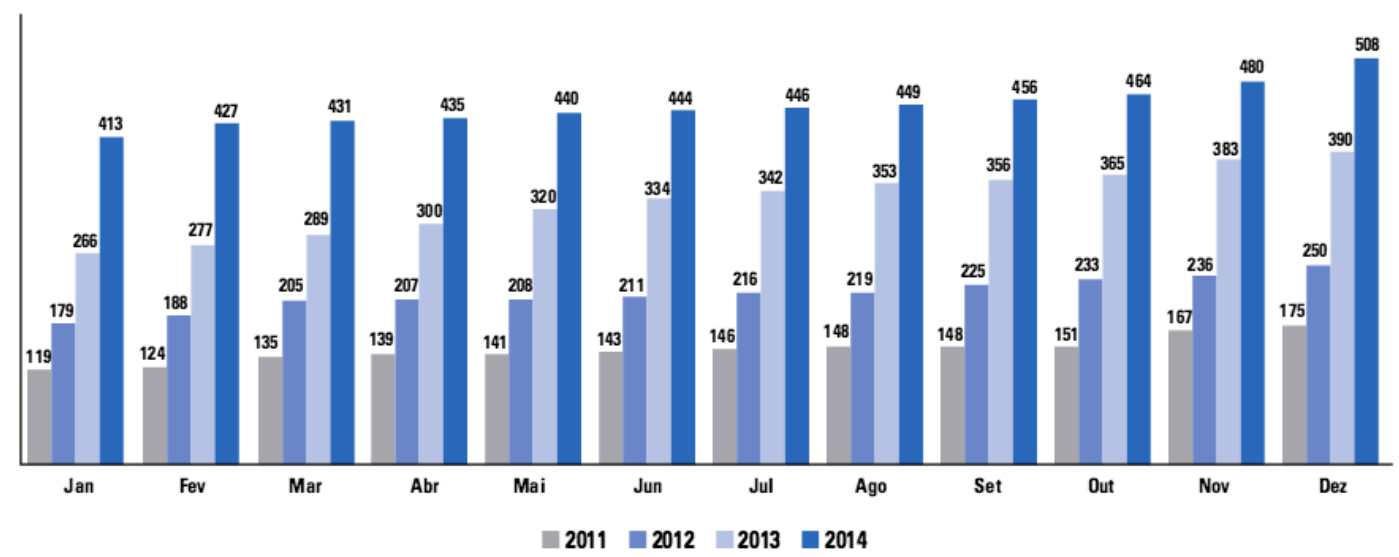

Fonte: Anuário ABPI-TV 2014.

É possível verificar o crescimento vertiginoso de produtoras independentes durante o período destacado, o que repercute na diversidade de obras e vozes compondo o cenário midiático nacional. Apesar disso, é preciso fazer uma problematização que toca nosso objeto, produzido para múltiplas plataformas. $\mathrm{Na}$ era da convergência, à medida que as novas mídias aumentam sua demanda por conteúdos, elas também podem esvaziar de sentido a reivindicação de cotas de TV, já que agora as audiências podem acessar a programação fora da grade horária, na hora e lugar que lhes forem mais convenientes e na plataforma que lhes convier.

Para a maior parte da população, que ainda concentra na televisão sua principal fonte de informação e entretenimento, a lei do cabo cumpre sua função de democratização do mercado e estímulo à produção nacional. No entanto, não é possível ignorar que há um nicho de produção audiovisual que cresce à revelia de

\footnotetext{
${ }^{19}$ Fonte: site ABPI-TV - http://abpitv.com.br/site/imprensa/abpitv-atinge-a-marca-de-400associados/
} 
normas como essa, no território "livre" da internet - buscando seu financiamento e espaço nas redes. Seja como for, a Lei 12.485 contribuiu de maneira objetiva para a produção de inúmeros títulos nacionais e Latitudes entra nessa lista.

\subsection{Narrativas transmídia}

Levando em conta o cenário digitalizado em que vivemos na contemporaneidade, é importante considerar que a cultura da convergência (Jenkins, 2008) é um evento intrinsecamente ligado ao desenvolvimento tecnológico, e com fortes repercussões socioculturais, que possibilita novas formas de se contar histórias e, portanto, construir narrativas. É um fenômeno complexo que articula indústrias, sistemas e modos de produção, conteúdos, gêneros e formatos, uma vez que:

A convergência não depende de qualquer mecanismo de distribuição específico. Em vez disso, a convergência representa uma mudança de paradigma - um deslocamento de conteúdo midiático específico em direção a um conteúdo que flui por vários canais, em direção a uma elevada interdependência de sistemas de comunicação, em direção a múltiplos modos de acesso a conteúdos midiáticos e em direção a relações cada vez mais complexas entre a mídia corporativa, de cima para baixo, e a cultura participativa, de baixo para cima. (JENKINS, 2008, p. 310)

Ainda segundo Jenkins (2008, p. 311), vivemos "um momento de transição, no qual antigas regras estão abertas a mudanças" e dependem de uma complexa negociação que envolve tensões entre modelos de produção, distribuição e circulação de conteúdos tradicionalmente instituídos e a sua reconfiguração a partir de um cenário em que "as três formas de comunicação (interpessoal, comunicação de massa, e mass self-communication ${ }^{20}$ ) coexistem, interagem e que tanto complementam-se mutuamente quanto se substituem." (CASTELLS, 2009, p. 55).

É nesse cenário que emerge a narrativa transmídia (JENKINS, 2008) que, conforme resumem Lopes e Mungioli:

Trata-se da criação de um universo ficcional cujo conteúdo pode ser expandido tanto em termos de personagens quanto em termos

\footnotetext{
${ }^{20}$ Castells (2009, p. 55) conceitua mass self-communication como "uma nova forma de comunicação que emergiu, caracterizada pela capacidade de mandar mensagens de muitos para muitos, em tempo real ou em determinado tempo, e com a possibilidade de comunicação ponto a ponto, narrowcasting (comunicação segmentada) ou broadcasting, dependendo da proposta ou das características de uma determinada prática de comunicação."
} 
de desenvolvimento narrativo. Não se trata de uma repetição da história, mas de um desdobramento da história principal que ganha elementos diferentes (personagens, ambientes, conflitos) que tiram proveito das qualidades que cada um dos meios pode oferecer para o desenvolvimento da narrativa. (LOPES; MUNGIOLI, 2011, p. 253)

Desse modo, é notável que na era da convergência, as produções de entretenimento audiovisual tendem a se espalhar além da televisão e a ganhar outras plataformas, principalmente online. Quando se pensa na lei do cabo (como explicamos anteriormente, nome pelo qual ficou conhecida a Lei 12.485) como catalisadora do surgimento e crescimento de produtoras independentes no Brasil, teremos como consequência, além da multiplicação dos títulos nacionais veiculados na televisão, um aumento também das produções para internet.

Latitudes surge nesse cenário, despontando com conteúdos para as duas plataformas supracitadas e dialogando de maneira específica com seus respectivos públicos. É uma estratégia interessante, visto que a obra aproveita uma conjuntura favorável para a produção de audiovisual independente no Brasil e vai além da televisão, criando conteúdos para fora da lógica broadcast.

Esse uso possível das tecnologias digitais (entre tantas outras potencialidades) contrasta com uma apreensão estruturalista do pensamento sobre a ação social. O paradigma estruturalista entende o sujeito como produto das macroestruturas sociais, tais quais o Mercado, o Estado, a Língua, a Economia etc. Desse modo, sob essa perspectiva teórica, o todo - a estrutura - determina a parte - o indivíduo (Santini e Calvi, 2013).

Quando falamos em novas possibilidades a partir das mídias digitais, tendemos a nos confrontar com essa visão estruturalista do mundo. Devido ao sem número de alternativas de ação nas redes e à multiplicidade de práticas individuais, é possível entender esse ambiente como resultado de atuações somadas de vários indivíduos, e não o contrário. Para tanto, apoiamo-nos em Latour (2005), que entende as conexões e interações dos indivíduos em uma lógica de redes, infinitamente associadas.

A partir dessa perspectiva, portanto, podemos compreender os usos originalmente inimagináveis que foram dados à internet desde a sua concepção. Manovich (2001) define que operações técnicas mediadas por dispositivos de acesso à internet têm duas facetas: uma camada computacional e uma camada 
cultural. A primeira se refere à linguagem computacional nas redes, trânsito de dados, compactação e descompactação de arquivos, ou aos modelos de ação estabelecidos pela programação dos gadgets que em certa medida limitam a agência dos usuários. Há, por outro lado, a camada cultural, muito pertinente a essa etapa da pesquisa, que se refere às práticas e usos possíveis que não estavam previstas pelo protocolo técnico "oficial" de oferta dos conteúdos. Claramente, a estrutura nem sempre determina as práticas dos usuários, mas, muitas vezes, os usuários atuam de maneira a dar novas utilidades e subverter a estrutura, criando possibilidades inéditas de distribuição e consumo de entretenimento a partir de ferramentas da rede. Entre essas possibilidades, dois modelos se destacam: o streaming e o download.

O download funciona ao se transferir arquivos para o seu computador. Os conteúdos passam a ficar armazenados internamente e podem ser acessados mesmo sem conexão com a internet. Dentro da lógica de entretenimento audiovisual, essa prática é mais comum com produções televisivas, que, após a estreia na TV, por vezes são disponibilizadas para download na internet pela própria equipe de produção. Essa possibilidade dialoga com a camada computacional, a partir da qual é possível gravar os conteúdos de maneira “oficial”. Por outro lado, por mais que a indústria de mídias tente preservar seus títulos e não estabeleça canais formais de distribuição ou disponibilização de download, a camada cultural invariavelmente entra em ação e tem sucesso. A indústria fonográfica falhou na tentativa de impedir a propagação de músicas e álbuns pelas redes e o cenário se repete no mercado audiovisual de entretenimento na atualidade. Uma batalha perdida, de acordo com Martel (2012), já que os usuários sempre acharão maneiras de propagar e baixar os conteúdos que lhes interessarem.

Por outro lado, para acessar conteúdos em streaming, é imprescindível conexão à internet. Esse modelo funciona a partir da transmissão dos dados audiovisuais, que não podem ser gravados, mas visualizados online a qualquer hora e em várias plataformas (computador, tablet, celular, videogame etc). A lógica streaming vem justamente fazer oposição ao broadcast, ou seja, à grade de programação. É a partir desse paradigma que novos formatos de entretenimento se desenvolvem, a exemplo da websérie Latitudes, lançada concomitantemente à série televisionada.

O consumo de produtos audiovisuais em streaming transforma não só os 
hábitos da audiência, mas também os modelos de produção das obras. Elas são adaptadas a novas estéticas - que se referem principalmente ao tempo, fotografia e enquadramentos - para que circulem nas redes. Sem dúvida, o maior expoente dessa "nova geração" audiovisual é o YouTube, plataforma escolhida para servir como repositório e página de acesso da versão online de Latitudes.

O YouTube, por sua vez, opera sob uma lógica baseada na gratuidade. Ou seja, permite um fluxo extraordinário de conteúdos sem que o usuário pague diretamente por isso. Desse modo, a repercussão, a distribuição e a reprodução dos arquivos digitais disponibilizados nessa plataforma acontecem livremente, de maneira que as produtoras interessadas em disponibilizar seus títulos ali devem buscar novos modelos de financiamento e captação de recursos.

Outra característica do YouTube é o que se denomina "escalabilidade de redes", conceito cuja essência designa que quanto maior o número de usuários em uma rede, maior também é o seu valor. Esse teorema é análogo às medições das audiências tradicionais da TV, visto que atribui valor à plataforma de acordo com o seu alcance. No caso das redes virtuais, quanto mais pessoas conectadas em determinado canal, mais recursos são atraídos (na forma de publicidade), o que aumenta a possibilidade de investimentos para conseguir mais usuários e assim sucessivamente. Tal funcionamento impacta outros meios e plataformas não apenas pela via da criação, mas também pela possibilidade de os meios tradicionais terem de fazer frente a novos modelos de negócios.

Por outro lado, indagamos se o papel de intervenção do usuário será apenas uma mudança de estratégias de marketing ou algo mais radical que produzirá uma ruptura do conhecimento e do nosso sistema de valores. Os espectadores vão gozar de maior liberdade para interpretar as mensagens, porém menos autonomia com respeito aos valores neste mundo cada vez mais globalizado. Essas são questões que persistem, ao mesmo tempo, o conceito de TV broadcast, está sendo alterado pelos dispositivos móveis e os hábitos do consumidor com a introdução das novas tecnologias da comunicação e da informação. Já as mídias tradicionais como a televisão e o cinema passam por um processo de redimensionamento de suas funções e modelos de negócios bem como da produção de novos formatos e gêneros em seus conteúdos e na sua difusão. (AFFINI, 2008, ps. 7-8)

Desse modo, é possível perceber novos paradigmas estabelecidos na produção, distribuição e consumo de entretenimento audiovisual a partir da era da 
convergência. Nesse cenário, o estímulo resultante da lei do cabo catalisou esse processo no Brasil e forneceu algumas ferramentas para que os produtores criativos e independentes passassem a explorar esse novo universo de possibilidades. Um dos resultados foi o projeto transmídia Latitudes, que surge para ocupar diversas plataformas e experimentar novos modelos de negócio nas redes e fora delas.

\subsection{Transmidiação: uma tendência na produção ficcional brasileira?}

Antes de discutirmos a transmidiação como fenômeno midiático e possível tendência na produção ficcional brasileira, é preciso distingui-la conceitualmente de uma terminologia que também é usual na era da convergência: a crossmídia.

Utilizado principalmente pela publicidade e pelo marketing, desde os anos 1990 o termo define um conteúdo distribuído entre várias plataformas (Massarolo e Mesquita, 2014). Apesar de não precisarem necessariamente da internet para seu desenvolvimento, as ações crossmídia despontaram e tomaram lugar de destaque no mercado a partir das tecnologias digitais. Desse modo, se referem principalmente à circulação de produtos de mídia entre as plataformas tradicionais (cinema e televisão) e os novos meios, como sites, blogs e redes sociais.

Conceitualmente, cross-media nada mais é do que a possibilidade de uma mesma campanha, empresa ou produto utilizar simultaneamente diferentes tipos de mídia: impressa, TV, rádio e Internet. O cinema e a televisão mundiais estão repletos de exemplos destas práticas, da qual fazem parte, ativamente, os reality shows. (LUSVARGHI, 2007, p. 2)

Desse modo, apesar de terem surgido no contexto da cultura participativa e da convergência e, devido a isso, terem características similares, produtos crossmídia e transmídia se diferenciam em um ponto fundamental: à medida que o primeiro define o mesmo conteúdo circulando entre diferentes plataformas, o segundo traz a ideia de complementação, de narrativas que se integralizam com a fruição em cada uma das plataformas que as comportam.

Na cultura da participação (SHIRKY, 2011) um conteúdo transmidiático pode ser observado, como discutimos anteriormente, fora da esfera produtiva. Produções brasileiras e internacionais revelam vários casos nos quais títulos de ficção tiveram seus universos narrativos expandidos pela comunidade de fãs. Entre os casos mundialmente conhecidos dessa modalidade de participação de fãs, podemos citar Harry Potter e Matrix, por exemplo; no Brasil, o título Malhação 
(1995 -) também tem se mostrado um case de sucesso nessa linha de participação.

São exemplos de títulos cujos conteúdos foram retroalimentados por essa simbiose entre produção e audiência. É possível entender a transmidiação, portanto, para além das estratégias traçadas pela produção, ou seja, a partir das extensões (narrativas, visuais, musicais) criadas pelos usuários.

Essa perspectiva é amplamente difundida e aceita, mas para atender às especificidades desse trabalho, iremos enfocar o âmbito produtivo do objeto empírico. Entendemos que a repercussão nas redes sociais é muito importante para Latitudes e daria um estudo rico em outro momento, mas, por ora, a centralidade da discussão estará na definição de Fechine (2014) para a transmidiação. De acordo com autora, uma produção transmídia é estabelecida quando resulta da ação estratégica elaborada no âmbito produtor: "Na perspectiva que adotamos, as estratégias transmídias são oriundas necessariamente de uma instância produtora que, na maioria dos projetos bem sucedidos, corresponde a uma empresa, corporação, conglomerado de mídia" (FECHINE, 2014, p. 2).

Fechine (2014) chama atenção para o termo TV Transmídia, que vem sendo usado para se referir a uma lógica de produção, distribuição e consumo possíveis a partir das novas tecnologias de informação e comunicação e que se baseiam em maiores níveis de interação com as audiências. É precisamente a hipertelevisão (Scolari, 2014), que já foi apresentada anteriormente nesse trabalho.

O envolvimento do espectador é, a um só tempo, uma condição e o objetivo das experiências de transmidiação que temos analisado na ficção televisiva brasileira. Em trabalhos anteriores, definimos a transmidiação como um modelo de produção orientado pela distribuição em distintas mídias e plataformas tecnológicas de conteúdos associados entre si e cuja articulação está ancorada em estratégias e práticas interacionais propiciadas pela cultura participativa estimulada pelos meios digitais. Para os estudiosos do fenômeno, o desafio consiste, então, em identificar e analisar quais são essas estratégias e práticas que variam de acordo com o campo de produção (teledramaturgia, jornalismo, publicidade etc.). (FECHINE, 2014, p. 2)

Latitudes se encaixa nessa lógica ao oferecer novos conteúdos na plataforma televisiva, de maneira que o acesso à completude da criação não é apreendida no contato exclusivo com a produção no YouTube ou nas salas de cinema - apesar de isso ser possível em relação à diegese. À medida que a obra circula entre várias plataformas trazendo novos elementos para a fruição, ela se estabelece como mais 
uma produção transmidiáticas compondo o cenário de entretenimento brasileiro. Cenário que se desenvolve e profissionaliza vertiginosamente na contemporaneidade.

Em 2013, o Anuário do Observatório Ibero-americano da Ficção Televisiva (OBITEL) discute a importância que as redes sociais desempenham crescentemente na produção de conteúdos audiovisuais de entretenimento. Nesse ano, foi registrado, por exemplo, que sete dos dez trending topics do Twitter se referiam a Avenida Brasil no dia de exibição do último capítulo da telenovela ${ }^{21}$ (Lopes; Mungioli, 2013). Ainda nessa edição, foi identificada a retroalimentação entre os conteúdos de mídias tradicionais e os das novas tecnologias digitais, conforme explicamos anteriormente.

Portanto, nesse cenário de convergência midiática e de transmidiação, vemos empresas de televisão atuando com tecnologias da internet e, ao mesmo tempo, empresas de internet produzindo e distribuindo conteúdo de TV (LOPES; MUNGIOLI, 2013, p. 138).

No ano seguinte, o Anuário Obitel aponta o crescimento de usuários de banda larga no Brasil, devido ao barateamento do serviço e de pacotes mais acessíveis oferecidos pelas operadoras. Esse aumento é quantificado, e os dados revelam que, nesse período, o país já contava com mais de 100 milhões de pessoas conectadas à internet, 42 milhões delas por meio de dispositivos móveis. Além disso, o Brasil se posicionou como o maior expoente de usuários do Facebook entre os países latino-americanos e o Twitter alcançou um total de 46 milhões de assinantes ativos no país (Lopes; Mungioli, 2014).

Esse crescimento de acessos somado às novas possibilidades a partir das tecnologias de informação e comunicação resultou em um aumento significativo da fruição em streaming em detrimento da lógica broadcast. $\mathrm{O}$ crescimento do Video on Demand $^{22}(\mathrm{VoD})$ chegou não apenas para os produtores independentes, mas como estratégia de mercado de grandes corporações de mídia.

\footnotetext{
${ }^{21}$ É importante ressaltar que os dados publicados no anuário OBITEL 2013 se referem ao ano anterior, 2012. O mesmo ocorre para todas as outras edições do periódico, sempre referenciando data anterior à impressão.

${ }^{22}$ O serviço de Video on Demand, ou Vídeo sob Demanda, consiste na oferta de títulos disponibilizados em uma plataforma online, na qual o usuário pode escolher assistir na hora e lugar desejado, por meio do acesso em banda larga. Também é possível fruir a programação em diferentes dispositivos, como tablets, celulares, computadores, TVs digitais, videogames etc.
} 
Com os usuários de serviços on demand em rápido crescimento, os serviços de assinatura que oferecem parte da programação da emissora em streaming, como Globo.TV+ e Gshow (que disponibiliza conteúdos exclusivos para web, como webséries, videoclipes e tutoriais de moda, culinária e beleza), refletem essa estratégia, que também é seguida por alguns canais Globosat. O canal Off e o Canal Brasil, por exemplo, disponibilizam sua programação on-line para assinantes. Além disso, esses e outros canais, como SporTV, Combate e Premiere (todos Globosat), exibem conteúdos ao vivo pela internet para assinantes, seguindo o conceito de TV everywhere. (LOPES; MUNGIOLI, 2015, p. 127)

Especialmente no Brasil, o fenômeno da segunda tela foi fundamental para o desenvolvimento da transmidiação da maneira que ela se apresenta hoje. Além do volume crescente de conteúdos gerados pelas companhias de comunicação, os usuários também aparecem como atores ativos no cenário de entretenimento ficcional. Enquanto a programação é fruída por meio da televisão, ela também é comentada nas redes sociais, que reverberam os textos televisionados (Lopes; Mungioli, 2013).

O inverso também é verdadeiro, visto o recente investimento das indústrias de mídia no estímulo à circulação de seus conteúdos nas redes sociais. Durante a programação das emissoras, é comum a divulgação de websites, blogs ou hashtags relacionadas a títulos de ficção em exibição. Essas páginas servem muitas vezes como extensões das obras e trazem novos elementos para uma audiência cada vez mais conectada e exigente.

Todas as produções ficcionais da Globo, por exemplo, contam com um site oficial, hospedado no portal da emissora. Além disso, a maioria conta com espaços nas redes sociais e lojas online - com produtos exibidos nas telenovelas e séries, ou relacionados aos títulos. Ademais, algumas produções se desdobram em blogs de personagens, aplicativos para celulares, webséries com conteúdos exclusivos e mesmo páginas na internet de empreendimentos ou corporações ficcionais que compõem seu enredo (site de um hospital ou de uma agência de moda que concentra o núcleo de alguma telenovela, por exemplo). Há, inclusive, autores e diretores de ficções televisivas muito influentes nas redes sociais, que abrem suas páginas (principalmente no Twitter) como um canal direto de comunicação com os fãs.

Desse modo, é possível observar alguns modelos de estratégias de inserção 
da programação televisiva nas redes. Vale destacar, no entanto, que a indústria da comunicação brasileira ainda prioriza maciçamente a televisão, principalmente porque esse meio ainda lidera de longe os investimentos publicitários nacionais, como pode ser observado na tabela seguinte:

Tabela 2: Investimentos publicitários 2015

\begin{tabular}{c|c|c}
\hline \multirow{2}{*}{ MEIOS } & \multicolumn{2}{|c}{ Jan a Dez/2015 } \\
\hline Total & R\$ (000) & {$[\%]$} \\
\hline TV ABERTA & 132.059 .608 & 100 \\
\hline JORNAL & 69.961 .861 & 53 \\
\hline TV ASSINATURA & 16.851 .771 & 13 \\
\hline DISPLAY* & 15.064 .924 & 11 \\
\hline TV MERCHANDISING & 8.724 .182 & 7 \\
\hline REVISTA & 6.945 .328 & 5 \\
\hline RADIO & 5.386 .908 & 4 \\
\hline SEARCH* & 5.173 .378 & 4 \\
\hline OOH** & 1.640 .247 & 1 \\
\hline CINEMA & 1.585 .447 & 1 \\
\hline
\end{tabular}

Fonte: Kantar IBOPE Media.

É possível perceber a TV aberta como detentora de mais da metade dos investimentos publicitários brasileiros em 2015. Se somada com a TV paga e o merchandising em televisão, os números do veículo alcançam $69 \%$ do total gasto com propaganda no país durante o último ano. ${ }^{23}$

Apesar disso, não é possível deixar de considerar seu crescimento gradativo

\footnotetext{
${ }^{23}$ Porém, não é possível mensurar seu crescimento em relação aos anos anteriores já que o grupo Kantar IBOPE Media modificou as ferramentas de coleta de dados conforme informa em sua página online $^{23}$, justificando a ausência da internet entre as medições: "A partir de 2015, deixamos de reportar as informações de Internet em sua metodologia declarada, e a substituímos por coleta própria e de forma amostral, que denominamos Display. Portanto os valores de Internet 2014 e Display 2015 não devem ser comparados" (disponível em: https://www.kantaribopemedia.com).
} 
no cenário midiático nacional, o que definitivamente colabora para as experimentações e traz novas possibilidades de realização de produtores independentes, menos engessados às regras mercadológicas e mais livres para ousar. Nesse cenário, surge Latitudes com sua matriz de produção para internet, dando novos usos às plataformas tradicionais, conforme veremos a seguir.

\subsection{Latitudes: a matriz de produção para a internet}

Como afirmamos anteriormente, Latitudes é uma narrativa que foi produzida para ser vista em várias plataformas. Sua estratégia de exibição trouxe mudanças em relação ao que em geral acontece com os produtos audiovisuais que têm entre suas plataformas a televisão. Ao invés de a narrativa se concentrar na televisão e ser estendida ou expandida para a internet, em Latitudes a própria internet constitui-se como nave-mãe (Jenkins, 2008) e concentra a diegese. É uma estratégia de distribuição ousada, que privilegia a gratuidade e o potencial de alcance de plataformas como o YouTube.

Inicialmente disponibilizado no canal do YouTube, o episódio televisionado contém a mesma trama diegética disponível online, porém apresenta também os extras da produção. Além disso, os produtores buscaram a criação do público a partir das duas primeiras plataformas citadas, para que as audiências comparecessem também às salas de cinema, a fim de reassistir à narrativa com pequenas alterações na edição e trilha sonora. Por ter sido veiculada inicialmente pela internet, Latitudes seria uma produção que já chegaria aos cinemas com um público formado ${ }^{24}$. Percebe-se, portanto elementos da chamada estética da repetição (Calabrese, 1988) como estratégia de narrar transmidiaticamente a obra. Desse modo, a dinâmica da repetitividade e da serialidade, utilizada por muitas obras contemporâneas, pode dar margem ao "espalhamento" dos títulos em diversas plataformas. De maneira geral, a estética da repetição consiste na utilização de elementos que induzam à continuidade das tramas, seja em episódios, capítulos, temporadas ou spin-offs.

Aí se identifica mais uma estratégia da produção, que envolve a criação de um público na internet, para que este busque novos conteúdos na televisão e

\footnotetext{
${ }^{24}$ Fonte: Folha de São Paulo - Ilustrada: http://www1.folha.uol.com.br/fsp/ilustrada/154946-emtodas-as-telas.shtml
} 
compareça às salas de cinema, mesmo já conhecendo a história desenvolvida na trama. Percebe-se, portanto, que a trama na internet serve como um modelo-base, um protótipo a partir do qual "articulam-se modos diferentes de repetições, seja no modo temático, no icônico ou no narrativo" (Zanetti, 2009, p. 185).

Nesse ponto, cabe salientar que a websérie Latitudes no YouTube se destaca como núcleo da diegese, além de plataforma original de divulgação da ficção. A partir da descrição dos vídeos no site, a audiência é chamada para conferir a produção na TV, com conteúdos adicionados. É interessante perceber que esse "chamado" não ocorreu por meio de possíveis desdobramentos da trama, mas a partir de um modelo de distribuição - que priorizou o veículo online. Ainda que, no decorrer das semanas, os episódios avançassem concomitantemente no canal TNT e no YouTube, eles foram lançados originalmente na plataforma digital, para depois serem exibidos na televisão. Desse modo, a internet se estabelecia como o primeiro contato com a produção, como o meio original a partir do qual a audiência pode buscar novos conteúdos. O cinema, cronologicamente em termos de estreia, se configura como a última plataforma a comportar Latitudes. Essa lógica de distribuição parece pressupor certo envolvimento do público a partir das versões veiculadas anteriormente.

O que diferencia os episódios online dos televisionados é precisamente que, na televisão, seu conteúdo foge do universo puramente diegético e são reveladas particularidades da produção. A narrativa ficcional permanece a mesma, mas surgem complementações que explicam a produção da trama e apresentam detalhes comportamentais das personagens. Em vários momentos da narrativa televisiva, por exemplo, o diretor Felipe Braga entra em cena lendo partes do roteiro, enquanto a sequência se desenvolve, trazendo explicações acerca dos acontecimentos que se desdobram na diegese. A atriz Alice Braga (Olívia), no meio de um ensaio da cena apresentada no terceiro episódio ( $3^{\circ}$ Destino - Veneza) na televisão, aparece descrevendo os desejos e anseios de controle característicos de sua personagem. Essas estratégias funcionam como uma forma de desconstrução da obra em sua dimensão discursiva e narrativa (quebra de temporalidade, espacialidade, instância enunciativa) ao mesmo tempo em que estabelece um novo discurso em que se mesclam as falas (confissões) das personagens e a ação diretor (por trás das câmeras) denunciando dessa forma o caráter criativo da ficção.

No cinema, a estrutura narrativa ganha (pequenos) novos cortes e trilha 
sonora, mas a história se desenvolve basicamente da mesma maneira que foi disponibilizada na internet. Por ter sido a última plataforma, o cinema pode ser encarado como uma oportunidade de assistir na "telona" uma história que já cativou o público pela internet e televisão.

Em uma aproximação mais cuidadosa, pode-se dizer que a televisão possui um papel secundário, ou seja, funciona como plataforma satélite da plataforma web, cumprindo o papel de propagar a narrativa exibida no YouTube. Fica clara, portanto, a opção estratégica de conferir a cada uma das mídias um papel na constituição do universo narrativo de Latitudes. Cabe salientar que o conteúdo extra oferecido na televisão não expande o universo diegético da narrativa, ao contrário, age no sentido de apresentá-la como uma narrativa ficcional e revela detalhes de sua produção, elucidando desde técnicas de iluminação e enquadramento, até o ponto em que os sentimentos sugeridos pelas personagens na trama são descritos detalhadamente pelos atores e diretor. Esse conjunto discursivo complementar caracteriza-se como uma espécie de making of da produção, apresentado de maneira parcelada em episódios semanais nos quais se mesclam a narrativa ficcional e a narrativa sobre a ficção, constituindo um enunciado sobre o enunciado (Bakhtin/Volochinov, 2002). Ou seja, um discurso dentro do discurso.

O que é interessante notar nessa situação é a inversão que se observa em relação ao papel da televisão, historicamente hegemônica na veiculação de produtos ficcionais, especialmente quando se leva em conta a América Latina. O mesmo vale para o cinema, que também sempre concentrou a "fina flor" da realização audiovisual nos EUA, Europa e em outras partes do mundo. No caso de Latitudes, o esquema de distribuição trabalhou fortemente com o ambiente online, que inclusive precedeu as mídias tradicionais. Ter essa perspectiva é importante para dimensionar o papel do YouTube na distribuição e repercussão de novos formatos audiovisuais de ficção.

Desse modo, percebe-se o YouTube e a oferta online de conteúdos como mais que meras complementações ou complexificações das narrativas televisuais ou cinematográficas. Felipe Braga, diretor da obra, reforça essa perspectiva ${ }^{25}$ : "Nós queríamos estrear online justamente porque sempre ocorre o oposto: a internet é normalmente encarada como plataforma para se jogar o que tem de menos valor, os

\footnotetext{
${ }^{25}$ Fonte: Folha Ilustrada: http://www1.folha.uol.com.br/ilustrada/2014/03/1420884-latitudes-e-bomde-merchandising-mas-nao-atraiu-investidores.shtml
} 
extras".

Do ponto de vista da estrutura narrativa e discursiva da versão de Latitudes para o cinema, podemos dizer que ela se caracteriza basicamente pela concentração de todos os episódios, reeditados, com ligeiros cortes e alterações de montagem. A principal mudança estrutural do filme em relação às narrativas seriadas de Latitudes é o preenchimento de diálogos com imagens, quando eles originalmente eram encenados pelas personagens. No $2^{\circ}$ Destino - Londres, por exemplo, em uma sequência que originalmente mostrava um plano de José e Olívia dialogando, as cenas das personagens conversando sobre seu encontro no $1^{\circ}$ Destino - Paris foram cobertas por imagens do dia de Olívia em Paris (cenas sem diálogos que a mostravam sozinhas antes de encontrar José na capital francesa), que não existem na trama seriada - nem no YouTube, nem na televisão.

Em síntese, o longa metragem, embora apresente uma montagem diferente daquelas estabelecidas nas duas outras plataformas, serviu como uma forma de manutenção do conteúdo da narrativa transmídia. A principal diferença entre o filme e os episódios disponibilizados no YouTube se refere à construção narrativa e discursiva das cenas em que surgem as memórias das personagens, que, nas versões seriadas de Latitudes, eram apenas narradas. No cinema, elas foram cobertas com imagens, permitindo que o público "visse" essas memórias em pelo menos dois momentos: 1) em Londres, lembrando o dia que poderiam ter passado juntos em Paris e 2) durante a viagem de Olívia do Porto para Buenos Aires, na qual ela aparece sentada no avião com o celular nas mãos. Ou seja, trata-se de conteúdos ficcionais inéditos na história narrada anteriormente em outras plataformas que, no entanto, não expandem o universo ficcional (Jenkins, 2008).

É possível definir, portanto, a websérie Latitudes disponibilizada no YouTube como a nave-mãe (Jenkins, 2008) da produção ficcional. Ou seja, é a narrativa que concentra a trama central a partir da qual se espera que as audiências partam para novas plataformas em busca de informações adicionais.

Pensemos, por exemplo, naquilo que as extensões transmidiáticas fazem. Elas oferecem informação adicionais e a oportunidade de explorar mais plenamente os mundos ficcionais. Permitem o engajamento com histórias de pano de fundo ou realçam o impacto a longo prazo dos eventos narrativos. Ou, ainda, redirecionam o foco em torno das perspectivas de personagens secundários ou periféricos, retornando à "nave-mãe" com um novo quadro de referência. Neste momento, no 
Brasil, estamos ainda mapeando o território, identificando dispositivos formais e modos narrativos que funcionam num ambiente transmidiático, esbarrando ocasionalmente em exemplos que contêm grande força emocional ou complexidade cognitiva (Jenkins apud Navarro, 2010). Existem, no entanto, profissionais monitorando os experimentos e refinando a arte. Entre eles, estão os artistas que vão levar as produções transmidiáticas ao próximo nível. E também os consumidores, que vão acompanhar esses artistas e ajudá-los a realizar plenamente o seu potencial. 


\section{CAPÍTULO 5 : YOUTUBE: A NOVA FRONTEIRA}

A primeira especificidade do YouTube que cabe destacar se refere à sua diversidade. A possibilidade de qualquer usuário realizar o upload de conteúdos no site garante à página uma dinâmica particular, que reestrutura a todo o momento a organização dos vídeos disponíveis na plataforma (Burgess; Green, 2009). Essa "democratização" das possibilidade de acesso quebra barreiras geográficas antes impostas às audiências (televisivas), que agora têm recursos para estabelecerem conexões com usuários ao redor do mundo, por meio da internet.

Essa nova conjuntura permite, por um lado, a organização de grupos e a “produção mútua e troca recíproca de conhecimentos e servem como locais de discussão e partilha de conteúdos" (CASTILHO, 2014, p. 198), além do estabelecimento de comunidades virtuais com interesses comuns. Por outro lado, a popularização do uso do YouTube pela indústria de mídia, conforme explicitado anteriormente, globaliza, potencialmente, os conteúdos disponibilizados. Desse modo, podemos compreender a plataforma como um meio de difusão de conteúdos, um repositório a partir do qual há manifestação de práticas culturais diversas e, mais recentemente, inserção de fortes interesses comerciais de grandes emissoras de televisão e produtoras audiovisuais.

Para entender de que maneira esses usos do YouTube foram estabelecidos, é importante traçar um breve histórico do site, definindo como ele se tornou o que é e representa hoje para o cenário midiático brasileiro e mundial. Criado em 2005 por dois jovens funcionários de uma empresa de tecnologia ${ }^{26}$, o site nasceu como um meio de compartilhar vídeos pessoais com amigos. De acordo com os criadores Chad Hurley e Steve Chen, em entrevista à revista Fortune ${ }^{27}$, a ideia surgiu devido à dificuldade de enviar por e-mail ou publicar na rede uma gravação feita em um jantar informal. A partir do intuito de facilitar esse compartilhamento, se origina o YouTube.

Cerca de 20 meses após sua criação, o site foi vendido por 1,65 bilhões de dólares para o Google, o que aponta sua relevância no mercado de mídias digitais.

\footnotetext{
${ }^{26}$ Trata-se da empresa PayPal, especializada em pagamentos e transferências de dinheiro via internet.

${ }^{27}$ Turning viral videos into a net brand: interview with Steve Chen and Chad Hurley, co-founders, YouTube. Disponível em: http://archive.fortune.com/magazines/fortune/fortune_archive/2006/05/15/8376860/index.htm (acesso em 30 de março de 2016).
} 
Hoje, segundo dados do YouTube ${ }^{28}$, a página conta com mais de um bilhão de espectadores, ou quase um terço dos usuários de internet no mundo. Por minuto, cerca de 72 horas de vídeo são disponibilizadas e a quantidade de horas de visualização (ou tempo de exibição) cresce a um ritmo de cerca de $60 \%$ ao ano. Apesar dos números impressionantes, uma reformulação no site foi fundamental para a reestruturação e consagração de sua força midiática na atualidade. Até 2010, os conteúdos publicados não poderiam ultrapassar 5 minutos por vídeo. Essa limitação temporal, no entanto, foi abolida, o que facilitou a inserção de produções televisivas na plataforma.

No decorrer da pesquisa, foi possível identificar que o modelo de produção e distribuição de Latitudes acompanha uma tendência no mercado audiovisual de entretenimento e da ficção seriada no Brasil. Nos último anos, é perceptível o número crescente de diversas produções que migraram da internet para a televisão. Nesse processo, o YouTube, principalmente, cumpre papel fundamental na constituição de públicos. Ao fazerem sucesso nas redes, os títulos são comprados por emissoras e passam a ser produzidos também para veiculação em mídias tradicionais. Guardadas as particularidades das audiências em cada meio, é uma receita com grandes chances de sucesso, pois levaria aos canais televisivos o que "já deu certo" na internet. No decorrer desse capítulo, discutiremos o trânsito de narrativas entre plataformas online e offline, além de identificar o YouTube como principal repositório de conteúdos audiovisuais na internet, que opera com suas próprias lógicas de anúncios e geração de recursos.

\subsection{Trânsito de conteúdos audiovisuais entre plataformas online e offline}

Para começar, é válido falar do case nacional de maior sucesso na internet até o momento, o Porta dos Fundos. Divulgando esquetes de humor sobre o cotidiano, é o canal brasileiro no YouTube com maior número de inscritos (seguidores), mais de 11 milhões $^{29}$. Em novembro de 2015, o Porta, como é conhecido informalmente, chegou à marca de 2 bilhões de visualizações somadas de todos os seus vídeos; também nesse período, ganhou o prêmio Play de Diamante, maior honraria concedida pelo YouTube aos produtores de conteúdos.

\footnotetext{
${ }^{28}$ Estatísticas do YouTube. Disponível em: https://www.youtube.com/yt/press/pt-BR/statistics.html (acesso em 30 de março de 2016).

${ }^{29} \mathrm{O}$ número de inscritos em 23 de março de 2016 é 11.482 .187 , de acordo com a página oficial do grupo no YouTube (https://www.youtube.com/user/portadosfundos).
} 
Seu reconhecimento já ultrapassou as fronteiras nacionais: mundialmente, é o $5^{\circ}$ canal com mais inscritos na categoria comédia e o $18^{\circ} \mathrm{com}$ mais inscritos em geral.

Nesse cenário sem publicidade em intervalos comerciais, o Porta dos Fundos garante seu financiamento por meio de inserções de marcas nos esquetes, sempre de maneira bem humorada. Um caso interessante foi o do episódio Fast Food, que conta a dificuldade de pedir uma refeição no Spoleto. O vídeo viralizou e passou a ser usado como publicidade pela rede de restaurantes. Depois disso, foi inclusive renomeado e se tornou Spoleto. Devido ao sucesso, a equipe foi contratada para realizar outros dois produtos audiovisuais de publicidade para a franquia do ramo alimentício.

Por conta do êxito na rede, a equipe começou a ser sondada por emissoras de televisão. Houve muita resistência sob o argumento de perderem a liberdade de tratar qualquer assunto, que é garantida na internet. Não por acaso, a página da plataforma fala com muito poucas restrições sobre religião, política, preconceitos e outros temas espinhosos para mídia tradicional brasileira. Ainda assim, em outubro de 2014, o Porta estreia na FOX, canal a cabo, que buscava produções nacionais para preencher horários com conteúdos nacionais, conforme demanda da Lei do Cabo, em um cenário que foi tratado no capítulo anterior. Na televisão, o programa tem duração de 30 minutos e, claro, a publicidade pode ser feita em modelos mais tradicionais. Além disso, estreou nos cinemas em junho de 2016 o filme Contrato Vitalício, realizado pela equipe do Porta.

Apesar de ter sido o caso com mais repercussão, o Porta dos Fundos não inaugurou a tendência de levar títulos que despontaram na internet para a televisão. Em 2005, um grupo de teatro criado nos corredores da Escola de Artes Dramáticas da Universidade de São Paulo estreou o espetáculo As Olívias Palitam, levando aos palcos a dramatização humorística de situações cotidianas sob um "olhar feminino". O sucesso resultou na criação de uma websérie semanal, As Olívias Queimam o Filme, que começou a ser disponibilizada no YouTube em 2009.

O grande número de inscrições na página e visualizações levou à compra dos direitos do grupo pelo canal Multishow, da Globosat, onde foi exibida $A s$ Olívias na TV. Seguindo o formato de esquetes sobre situações aparentemente comuns, a série televisionada está encerrada atualmente, mas teve quatro temporadas. O sucesso foi reconhecido pela indicação por dois anos seguidos como a melhor série de humor da TV paga, pela revista Monet. 
Ainda nessa linha, a websérie Quero Ser Solteira, que estrou no YouTube em junho de 2011, conta a história de uma mulher que sai da casa de sua família no interior para cursar a faculdade de moda na capital do Rio de Janeiro. Ela passa a explorar sua independência e conta de maneira cômica as situações que vive na cidade grande. Interessado, o Multishow produziu uma versão televisiva da trama, que foi veiculada em outubro de 2012.

Mais recentemente, é possível observar produções fora da esfera ficcional trilhando esse percurso. O Manual do Mundo é um site brasileiro, criado em 2008, especializado em entretenimento educativo. A maior parte dos seus conteúdos é distribuída em vídeos no YouTube, que contam de maneira divertida aventuras com experiências científicas, receitas, pegadinhas, mágicas e outros temas atrativos principalmente para o público infanto-juvenil. A ideia é estimular o interesse pela ciência, tornando-a mais acessível e divertida. O sucesso na rede levou à criação, em outubro de 2015, de uma versão televisiva dos vídeos, o Manual do Mundo na $T V$, exibido pelo canal a cabo PlayTV.

Também nessa emissora é exibido o Miolos Fritos, que começou com uma dupla de publicitários fazendo receitas de maneira descontraída em um canal no YouTube. Misturando culinária e cultura pop, o programa vai ao ar três vezes por semana e é mais um caso de sucesso entre conteúdos da internet que viralizaram e se popularizaram entre o grande público televisivo.

Ainda nessa linha gastronômica, observamos também o Rainha da Cocada, que começou com um canal no YouTube mostrando a rotina e as receitas de uma chef pâtissière brasileira em New York. Seus vídeos já passaram de 15 milhões de visualizações e 300 mil assinantes no site, e agora a chef Raiza Costa assina também um programa diário na GNT, com o mesmo nome e conteúdo parecido, devidamente adaptado para a plataforma.

Além dessas adaptações de conteúdos da internet para a televisão, dessa vez envolvendo o provedor de filmes e séries em streaming Netflix. O site já iniciou as gravações de $3 \%$, sua primeira série totalmente brasileira. Com a trama ambientada em um mundo distópico onde somente $3 \%$ da população tem chances reais de sobreviver, a produção, assim como os exemplos trazidos anteriormente, tem origem em uma websérie com o mesmo nome (apenas o webisódio piloto foi efetivamente produzido e está disponível na página Série 3 Por Cento no YouTube). Só que, dessa vez, a obra não tem seus direitos comprados por uma 
emissora para ser produzida e veiculada na televisão, mas por uma plataforma de distribuição on demand. Sem dúvida, um sinal dos novos tempos de convergência, que nos leva a pensar na profissionalização da produção de conteúdos na internet.

É interessante refletir também sobre as proporções que os títulos ganham ao serem lançados em um site como o Netflix. $\mathrm{O}$ alcance deixa de ser nacional, preso às possibilidades de distribuição da televisão, e passa a ter, potencialmente, o mundo inteiro como público. As lógicas de produção e consumo se aproximam muito mais das webséries disponibilizadas no YouTube e menos da dinâmica baseada na grade horária da TV. Nesse sentido, não é possível apontar aspectos que diferenciem o produto midiático das webséries, a não ser o aporte financeiro maior e o caráter de superprodução assumido. A previsão de lançamento de $3 \%$ no Netflix é para o fim de 2016 e, sem dúvida, trará bases interessantes para discussão de formatos, realização, distribuição e consumo na era da hipertelevisão e das novas plataformas digitais de comunicação e informação.

Como é possível perceber pelo período de lançamento dos títulos, esse é um território ainda muito recente e, portanto, pouco explorado. O que se pode dizer, por enquanto, é que configura uma tendência na produção de conteúdos ficcionais e de entretenimento no mundo e no Brasil. Também é importante apontar a relevância que as redes sociais assumem na propagação desse modelo. Além das páginas oficiais, todas as séries contam com perfis e espaços em sites de relacionamentos, onde possibilitam a discussão entre os integrantes do público e com a própria equipe de produção.

Enquanto parte desse cenário, é possível questionar a relevância de Latitudes: o que a diferenciaria das demais produções, tornando-a importante para uma análise aprofundada? A resposta consiste na concepção da obra. Desde o princípio, o título foi idealizado como um produto transmídia, que seria disponibilizado no YouTube e veiculado na televisão e nas salas de cinema.

Diferentemente de todos os exemplos trazidos até agora, Latitudes é um reflexo único, até o momento, dos novos tempos na produção de mídia: não seguiu o sistema de disponibilização em uma plataforma gratuita e mais democrática para, em seguida, ter seus direitos comprados pela indústria de comunicação. Já entrou no mercado transitando entre as plataformas online e offline. Percorreu um caminho inédito até então no Brasil, conciliando as possibilidades das redes com a distribuição em veículos tradicionais. Desse modo, a obra experimenta um modelo 
que aglutina o "melhor de dois mundos", investindo na profissionalização, em componentes renomados envolvidos na realização, maior facilidade de captação de recursos e alcance potencialmente ilimitado de audiências possível a partir da internet.

Acreditamos, portanto, que Latitudes não apenas acompanha uma tendência irreversível na produção de conteúdos, mas inaugura a experimentação de novos formatos de distribuição e consumo. Em meio a uma profusão de títulos que representam a simbiose entre internet e mídias tradicionais que surgem no cenário midiático nacional, a obra se apresenta com diferenciais interessantes para analisar a produção transmídia brasileira e suas novas possibilidades.

\subsection{Disponibilização da produção televisiva na internet}

Umas das estratégias transmídia mais comuns na expansão das narrativas televisuais brasileiras para a internet consiste na criação de blogs de personagens. De acordo com Karhawi (2013), já em 2006 a Globo lançou o diário virtual das protagonistas Piti e Belinha, da série Sob Nova Direção (2004 a 2007). Foi o primeiro blog de personagens registrado na emissora. A prática cresceu e persiste até hoje como maneira de estreitamento das relações entre produtores e público. Não se pode iniciar essa discussão, no entanto, sem levar em conta os problemas de acesso às tecnologias da informação e da comunicação e mesmo à internet no Brasil. A presente conjuntura não anula a produção para a web, mas é importante considerar que ela não tem alcance universal.

Essa restrição inibe o crescimento ilimitado de ações transmídia que condicionem a compreensão de narrativas televisivas ao acesso dos conteúdos disponibilizados nas redes. Apesar disso, como veremos, estratégias de distribuição de extensões narrativas de telenovelas e séries em sites oficiais e redes sociais são cada vez mais comuns. Isso aponta para um cenário de progressiva democratização de acesso à internet no país e envolve questões geracionais.

Obviamente, não é toda a parcela da audiência que chega até os blogs, até essa extensão da narrativa televisiva. Poderíamos levantar as problemáticas da faixa etária, da falta de acesso à Internet e mesmo da falta de interesse. Assim, sabendo que "nem todo mundo está globalizado: as redes conectam e desconectam ao mesmo tempo" (CASTELLS, 2008, p. 81). Talvez a grande vantagem da transmedia storytelling nesse sentido seja o balanço que há nessa desconexão: a parcela da audiência que não está conectada, não perde a narrativa. A discussão não se restringe ao 
ciberespaço, mas transborda para ele, encontra no ciberespaço um apoio para a proliferação de seu relato. Portanto, a despeito de outros produtos, ou espaços de discussão, pensados exclusivamente para o ciberespaço, a transmedia storytelling permite que a narrativa principal não se perca e seja o original sustento de todas as outras. (KARHAWI, 2013, ps. 75-76)

Além dos blogs de personagens, os sites oficiais das produções ficcionais da Globo (que será levada em conta por ser a emissora que concentra os títulos de ficção com as maiores audiências ${ }^{30}$ ) trazem inúmeros conteúdos que estimulam a interação do público com o que é exibido na televisão. Há apresentação dos personagens, jogos, matérias em tom jornalístico apresentando os conflitos dos personagens como se eles fossem reais, entrevistas com o elenco, entre uma infinidade de produtos.

Quando falamos, no entanto, sobre o trânsito de conteúdos entre televisão e internet, cabe lembrar de uma estratégia de expansão narrativa que vem se popularizando entre os títulos da Rede Globo e ganhando espaço frente ao público conectado às redes: as webséries. Sejam narrativas relacionadas às tramas televisionadas ou "independentes", são novos conteúdos disponibilizados exclusivamente na internet, que refletem um novo modelo de interação com as audiências e de consumo das produções ficcionais.

Na página oficial da emissora ${ }^{31}$, o GShow, há 37 webséries disponíveis para visualização. Entre elas, extensões narrativas da programação televisionada, como o Lembranças do Irajá, que se refere ao bairro onde se passa a série Pé na Cova, o Dupla Identidade.doc, que traz a construção das personagens da série Dupla Identidade, o Verdades Secretas.doc, que, analogamente, remete à trama da série Verdades Secretas, os Causos do Zé Coveiro, da minissérie Amorteamo, Os Desatinados, desdobramento online de Malhação, entre vários outros.

Servem para criar um sistema de retroalimentação que, nas redes, estimula que as audiências recorram aos televisores para acessar as tramas apresentadas e, a partir da televisão, vão ao site oficial da emissora para acompanhar extensões dos conteúdos exibidos.

Em resumo, nos perfis das emissoras, a fronteira entre produtores e consumidores é delimitada pelo discurso, pela forma como fomentam a curiosidade do público ao anunciar os próximos

\footnotetext{
${ }^{30}$ Fonte: Anuário OBITEL 2010, 2011, 2012, 2013, 2014 e 2015.

${ }^{31}$ Disponível em: http://gshow.globo.com/webseries/.
} 
eventos narrativos, numa nítida tentativa de atrair as audiências para o produto central - a telenovela emitida na $\mathrm{TV}$. (CASTILHO, 2014, p. 192)

As produções, no entanto, não se restringem às tramas televisivas, sendo muitas delas, como falamos anteriormente, "independentes". Ou seja conteúdos exclusivos, feitos sob o "padrão Globo de qualidade", que não compõem a grade de programação da emissora, mas são disponibilizados apenas no site oficial. Há uma radionovela, tutoriais de beleza, dicas de moda, uma série sobre cuidados com animais de estimação, entre outros conteúdos com temáticas diversas. Pode parecer trivial, mas esse modelo de produção e distribuição aponta para novas formas de consumo adotadas pela emissora com maior audiência do país, que já não mais concentra todos os seus conteúdos na televisão, mas experimenta novos modelos narrativos.

Para se compreender a força da internet nesse cenário e a hibridação dos conteúdos produzidos, é interessante trazer um exemplo recente na teledramaturgia brasileira. Uma semana antes da estreia da telenovela Totalmente Demais, em novembro de 2015, foi lançado o capítulo zero, uma espécie de piloto, no portal GShow. Foi a primeira vez na história da emissora que os conteúdos de uma trama televisiva foram antecipados na internet, o que mostra a importância que as audiências online vêm assumindo.

O capítulo foi realizado com a equipe original da telenovela, escrito por Rosane Svartman e Paulo Halm e com Luiz Henrique Rios na direção. Diferentemente do que é mais comum nas produções para internet, que contam com atores novos da "casa" e têm caráter mais experimental, esse piloto contou com o time do primeiro escalão da Globo, elenco composto por Juliana Paes, Fábio Assunção, Marina Ruy Barbosa, Felipe Simas, entre outros. De acordo com Svartman, em entrevista à Folha de São Paulo, "Achamos importante levar a mesma história para uma tela diferente, mas sem comprometer e nem adiantar o que vai passar na televisão" ${ }^{, 32}$.

Essa ação inovadora da emissora faz parte de um conjunto de estratégias de divulgação do serviço em streaming oferecido pela companhia, o Globo Play. A

\footnotetext{
${ }^{32}$ Fonte: Caderno Ilustrada da Folha de São Paulo. Disponível em: http://www1.folha.uol.com.br/ilustrada/2015/10/1694659-globo-estreara-capitulo-zero-de-novelana-internet.shtml - ( acesso em 29 de março de 2016).
} 
plataforma de disponibilização de conteúdos on demand possibilita a visualização ao vivo da programação exibida em broadcast e também que o usuário busque videos de programas exibidos anteriormente, desde entretenimento, telejornais, até as telenovelas e séries produzidas pela emissora.

É uma maneira que a Globo encontrou de capitalizar seus conteúdos que já estavam circulando gratuitamente de maneira não autorizada na internet. Nesse ponto, vale lembrar da conceituação da camada cultural de Manovich (2001), tratada anteriormente. A guerra da indústria de comunicação na tentativa de restringir os conteúdos já começa perdida, como apontamos no capítulo anterior. A primeira medida da emissora foi tirar sua programação e seus títulos de sites e, principalmente, redes sociais, gastando dinheiro e energia em um processo que não chegava ao resultado desejado, devido principalmente à propagação exponencial dos conteúdos na web.

Desse modo, aparentemente, ao invés de "nadar contra a corrente" de circulação e consumo livres de conteúdos nas redes, a Globo lançou um canal próprio no YouTube, para a visualização de sua programação, disponibilizando seus títulos e capitalizando as audiências interessadas. Desse modo, o público tem acesso a um conteúdo de qualidade, transmitido na íntegra e legitimado pelo produtor - o que é vantajoso, visto que, na internet, nem sempre se sabe a procedência do conteúdo visualizado e por vezes a transmissão ocorre de maneira rudimentar.

Nasce, nesse contexto, o Globo Play, que traz para a internet os conteúdos televisivos da maior e mais lucrativa emissora brasileira. É um movimento importante para se considerar, visto que abre o leque de possibilidades de veiculação para além da plataforma televisiva. Desse modo, a internet deixa, de maneira indelével, de ser um espaço para produções amadoras ou experimentais e passa a contar com big players que disputam audiências e refinam a programação disponibilizada.

Além da inserção definitiva no ambiente online, a Globo também faz um movimento interessante que revela sua atenção às tendências da cultura participativa. Recentemente, a emissora lançou um edital chamando jovens talentos para participar da criação de uma websérie, que será disponibilizada na plataforma GShow. O projeto se chama GloboLAB e realizou inscrições até janeiro de 2016. Selecionou, até maio, candidatos com mais de 18 anos para participar de 
workshops, oficinas, visitas às instalações da Globo, palestras e mentoria de um profissional de renome da Globo, que irá orientar o desenvolvimento e formatação do projeto final. Após três etapas de seleção, um candidato será escolhido e terá seu roteiro produzido.

Desse modo, a emissora busca, a partir do projeto, desenvolver narrativas inovadoras e descobrir talentos criativos, para fins de realização de experimentações de linguagens e formatos em novas plataformas. Trata-se de uma adaptação da companhia às novas demandas do mercado de consumo de entretenimento. Produzir conteúdos nativos para a internet e renovar o quadro de profissionais são necessidades primordiais para sua inserção nesse novo cenário. A partir de ações como essa, é possível perceber a dimensão da internet nas lógicas de produção, distribuição e consumo de conteúdos audiovisuais no Brasil.

Todo esse ambiente em estado de transformação e redefinição aponta para a expansão das fronteiras do mercado de produção audiovisual brasileiro. Antes concentrado imperiosamente na televisão, agora ele precisa se adequar às novas tecnologias da informação e comunicação e consequentes demandas das audiências, explorando novas possibilidades e horizontes. A resposta da produção ocorre, no atual momento nacional, pela disponibilização de conteúdos em plataformas streaming e servidores on demand, que passam a dialogar com os conteúdos televisivos e se apresentam como mais um elemento do ecossistema midiático de entretenimento e ficcional.

A tendência ora apresentada fomenta a visualização de conteúdos na rede em detrimento da televisão. Sejam os conteúdos televisivos transpostos para sites de visualização em streaming, seja a produção de conteúdos exclusivos para a internet, os hábitos das audiências e as formas de consumo vêm sofrendo transformações que precisam ser trazidas à luz de análises aprofundadas.

O fenômeno de grandes produtoras do mercado midiático se inserirem cada vez mais profundamente nas redes, disponibilizando seus conteúdos pode ser observado em várias partes do mundo, inclusive no Brasil. Isso traz a necessidade de discussão sobre a maneira como ocorre essa inserção e que novos modelos de negócios e financiamentos são estabelecidos a partir dela.

\subsection{Consumo audiovisual no YouTube e novos modelos de negócio}

Para traçarmos algumas tendências de novos modelos de negócios que 
surgiram a partir da difusão de audiovisuais em streaming, é necessário, antes de tudo, entender que práticas culturais se apresentam nesse cenário. Para isso, Santini e Calvi (2013) traçam duas características fundamentais dos conteúdos que circulam nas redes. A primeira delas se refere à gratuidade; nesse sistema, a maior parte dos textos, vídeos, áudios e imagens circulam livremente entre seus públicos, sem que seja necessário pagar para obtê-los. A segunda engloba o que os autores chamam de "escalabilidade e redes", que faz uma relação direta entre o número de usuários envolvidos com uma determinada rede $\mathrm{e}$ a qualidade de seu funcionamento. Ou seja, em um ambiente formado pela gratuidade, o capital do conteúdo está na quantidade de acessos: quanto mais numerosos, maior o valor dos conteúdos.

$\mathrm{Na}$ Internet, onde milhões de indivíduos estão interconectados uns aos outros e exercendo uma influência mútua, as práticas de circulação e uso do audiovisual expressam duas importantes características que constituem a lógica social da Rede. Por um lado, a informação se propaga por imitação, repetição e reprodução de comportamentos, de forma instantânea e distribuída, em uma dinâmica de contágio viral e através da colaboração direta ou indireta entre milhões de pessoas. Por outro, os mecanismos desenvolvidos pelos usuários para difusão dos conteúdos tendem ao compartilhamento e ao consumo livre e gratuito dos mesmos - fenômeno que se constitui como uma tendência dominante na Internet. (Santini; Calvi, 2013, p. 166)

É claro que não se pode perder de vista o surgimento de operadoras de serviços on demand que trabalham com assinaturas, que dão acesso a seus conteúdos mediante pagamento de mensalidades, anuidades, ou mesmo pela compra individual de títulos. No entanto, ao levar em conta a profusão de vídeos no YouTube, inclusive sendo esse canal que comporta Latitudes, a distribuição gratuita, definida como majoritária, será o foco desse tópico de análise. Essa gratuidade, é possível inferir, é uma herança do modelo de consumo dos meios de comunicação de massa. Mídias como rádio e televisão operam nessa lógica, criando o hábito de acesso "sem custos" para a audiência.

Entretanto, desconsiderando as diferenças entre os formatos, conteúdos, plataformas e modelos comerciais emergentes, há uma lógica social em jogo no entorno online: os usuários que têm tempo e não têm dinheiro tendem a seguir buscando formas de acesso livre e gratuito aos conteúdos audiovisuais à margem de qualquer tentativa de impedimento e/ou controle por parte das indústrias ou dos Estados. Em contrapartida, os usuários que têm dinheiro, mas não possuem disponibilidade de tempo, tendem a 
preferir as garantias de direito e comodidade proporcionadas pelo consumo pago. (Santini; Calvi, 2013, p. 179)

O consumo privado de conteúdos de entretenimento se conforma de acordo com a lógica material sobre a qual opera. Em um ambiente de circulação gratuita, a propensão de experimentação dos usuários cresce, visto que não haverá custos para a reprodução de conteúdos. Ora, se não terá que pagar por eles, a audiência está mais disposta a fruir novos programas e mesmo mais condescendente em relação à sua qualidade. Em plataformas como o Netflix ou canais on demand de operadoras de TV a cabo, entretanto, onde é preciso pagar pelo acesso às produções audiovisuais, o consumo ocorre de maneira mais criteriosa.

Da mesma forma pode-se perceber que o entorno de gratuidade de conteúdos na Internet modifica a relação entre os usuários e as informações disponíveis de acordo com a liberdade de uso e a ausência de custos econômicos implicados no ato de consumo. Em relação aos bens culturais gratuitos, os usuários tendem a ser mais abertos e tolerantes culturalmente, porém quando é preciso pagar por estes bens os usuários se tornam mais exigentes, escolhem e selecionam o que consumir com critérios mais restritos. (Santini; Calvi, 2013, p. 173)

A circulação livre possível hoje se deve ao modelo de publicidade estabelecido, que arca com os custos de produção, operação e distribuição audiovisuais. Ao se transferir tal modelo de negócios às produções online, a quantidade de visualizações torna-se uma importante moeda de troca, à medida que serve para vender os espaços de conteúdos aos anunciantes, oferecendo um amplo alcance, potencialmente. Nessa dinâmica, obras com muitos acessos foram capitalizadas pelo maior repositório mundial de vídeos, o YouTube.

É interessante observar que, nesse sistema, o YouTube avança em penetração conforme os produtores de conteúdo alcançam mais visualizações. Desse modo, não é incomum observar o investimento do site em usuários e canais "promissores", que vão desde cursos de capacitação até disponibilização de estúdios para as gravações. São, portanto, ações a fim de alavancar ainda mais os responsáveis pelo sucesso da rede: os realizadores.

Há uma série de propostas de capitalização dos conteúdos no YouTube, muitas delas a partir de iniciativas individuais ou coletivas dos usuários. Para essa pesquisa, no entanto, iremos centrar esforços nos caminhos "oficiais" de captação de recursos e venda de espaços para propaganda disponibilizados pelo site. $\mathrm{Na}$ 
plataforma, são oferecidos três modelos de publicidade para os anunciantes. O primeiro e bastante comum é o anúncio gráfico, ou banner, que é exibido à direita do conteúdo em reprodução, acima da lista de sugestões de vídeos relacionados. É utilizado nos vídeos de Latitudes, conforme podemos observar em destaque na imagem abaixo:

Figura 15: Anúncio gráfico: banner
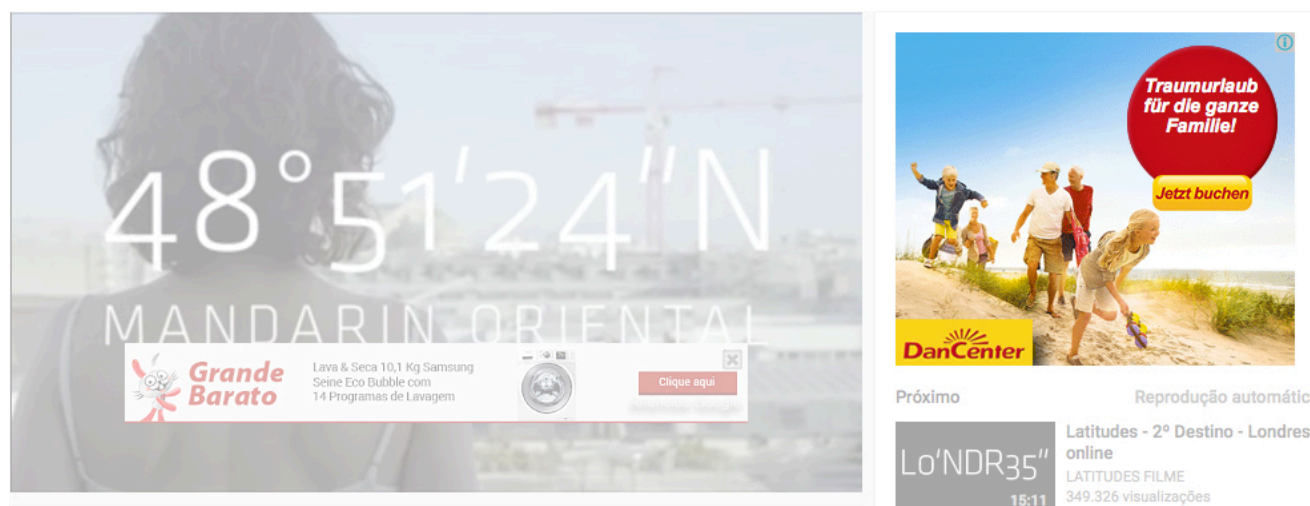

Próximo

O segundo, também bastante popular, consiste nos anúncios de texto, exibidos na parte inferior do vídeo em destaque, em sobreposição semitransparente. Geralmente ocupando cerca de $20 \%$ da tela, é uma maneira eficaz de atrair rapidamente a atenção da audiência por meio de uma visualização instantânea que objetiva a fixação da marca publicizada. Também está presente entre os webisódios de Latitudes, conforme observamos: 


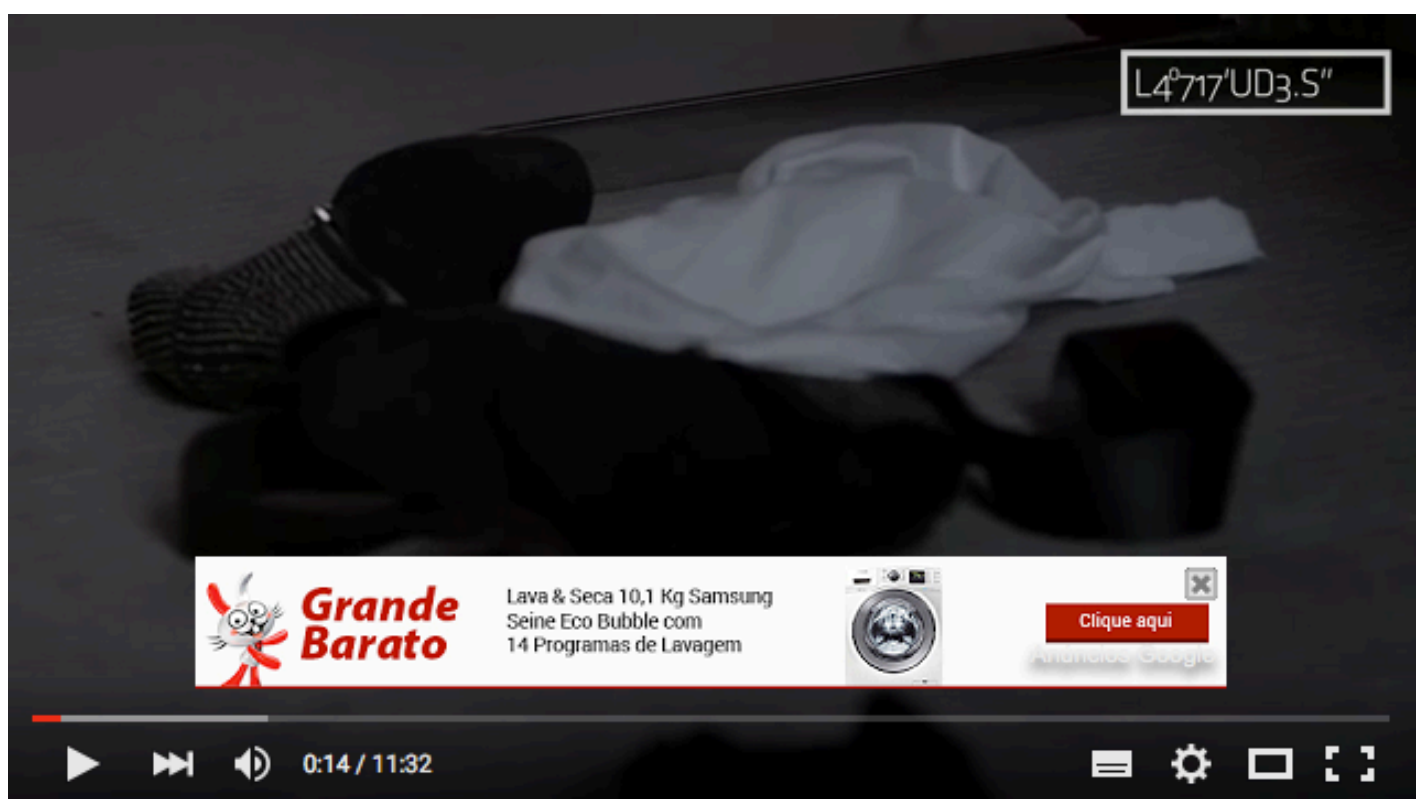

Por fim, o terceiro modelo de anúncio disponibilizado pelo YouTube se configura em vídeos de propaganda exibidos antes do conteúdo selecionado. São maneiras de apresentar marcas contundentemente, por meio peças publicitárias audiovisuais que se dividem em dois grupos: 1) anúncios em vídeo ignoráveis: podem ter alguns minutos de duração e é possível suprimi-los após cinco segundos de visualização; e 2) anúncios em vídeos não ignoráveis: são mais curtos, com até trinta segundos de duração, e não é possível passá-los adiante. Para visualizar o conteúdo escolhido, é preciso ver o anúncio integralmente. Entre os webisódios de Latitudes disponibilizados, só encontramos o anúncio em vídeos do primeiro modelo, conforme é possível verificar na imagem que segue: 


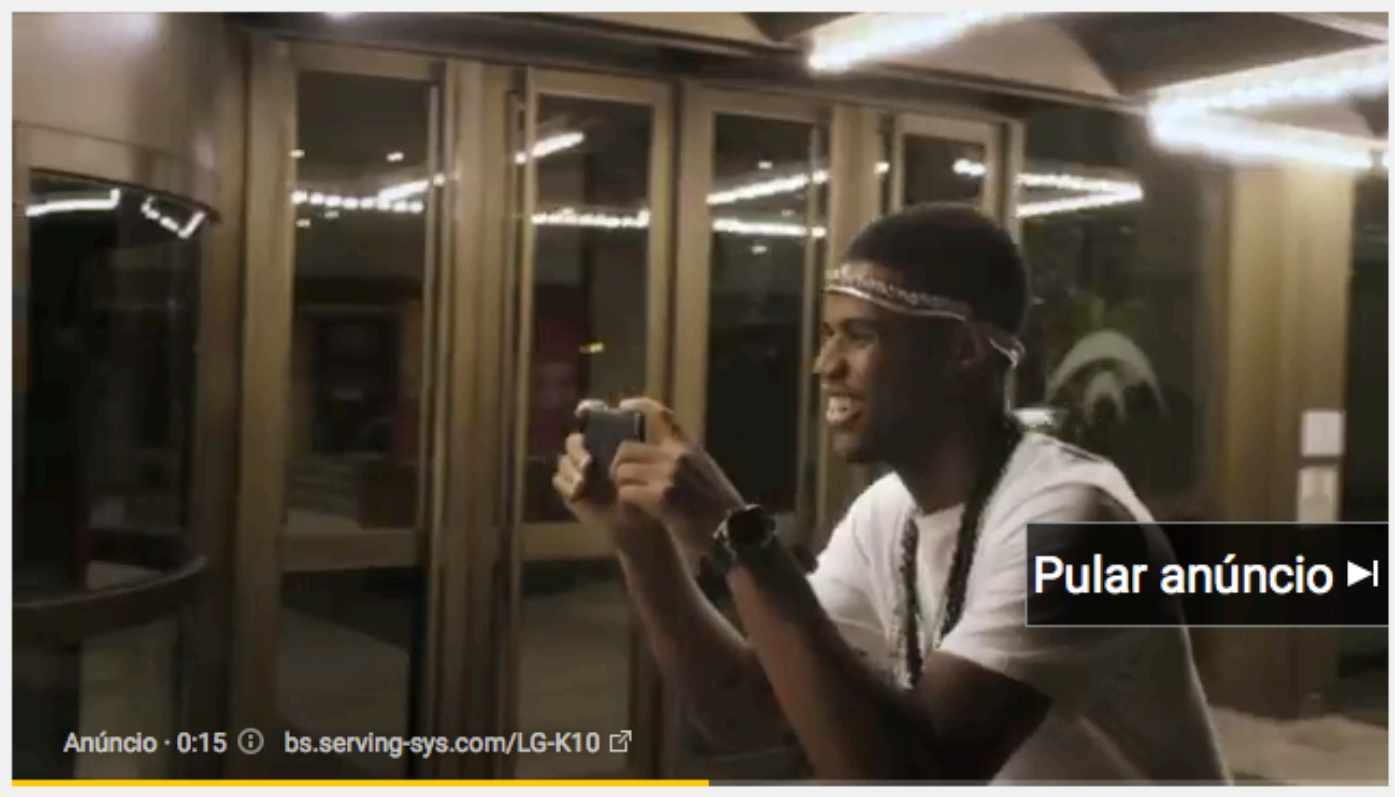

\title{
Latitudes $-2^{\circ}$ Destino - Londres - Versão online LATITUDES FILME

O detalhamento da questão publicitária no YouTube é importante quando propomos uma discussão sobre novos modelos de negócios a partir da distribuição de conteúdos ficcionais em múltiplas plataformas. Fugir da grade de programação, do broadcast e dos formatos tradicionais de propaganda só é possível a partir da compreensão de métodos de captação de recursos audiovisuais nas redes.

\begin{abstract}
Se no início "conteúdo online" significava apenas a disponibilização de informações, resumos, trechos de capítulos e notícias referentes à trama, na era de convergência as redes televisivas estão desenvolvendo narrativas e conteúdos específicos para a rede digital, para atender os consumidores dispostos a seguir seus programas favoritos através de múltiplos canais de comunicação. (MURAKAMI, 2012, p. 59)
\end{abstract}

Desse modo, é possível perceber que a versão online de Latitudes foi utilizada como veículo de anúncios dos três modelos disponibilizados pelo YouTube, o que revela em certa medida seu sucesso em quantidade de visualizações. Afinal, para que a publicidade seja feita, a exigência básica é que a produção à qual ela esteja vinculada tenha o mínimo de alcance entre os públicos pretendidos. Entre as vantagens oferecidas pelo YouTube, além do grande tráfego de usuários, está a possibilidade de segmentação dos anúncios entre grupos 
específicos, por meio do Google Adwords. Também é possível delimitar os horários de exibição dos anúncios, que, por meio do monitoramente do target, permite que sejam exibidos na faixa horária em que o público alvo está mais ativo na plataforma. A adaptabilidade da rede também é um diferencial, visto que o site está pronto para exibir seus conteúdos em tablets, celulares, computadores e SmartTVs, o que aumenta o alcance das ações, de maneira que o anúncio pode ser visto pelo consumidor em potencial em diversas mídias. Por fim, há a prerrogativa do pagamento por ação, que garante ao anunciante o benefício de pagar somente se o usuário executar a ação contratada pela campanha. Nesse modelo, o investimento ocorre por meio do Custo por Visualização (CPV) ou do Custo por clique na miniatura, que podem estar atrelados aos vídeos relacionados (na barra lateral do conteúdo em exibição) ou acessados por meio de pesquisa direta no site.

Para que um vídeo do YouTube sirva como veículo de anúncio, há uma série de fatores envolvidos. Faremos um resumo do percurso necessário para monetizar conteúdos amadores ou profissionais na plataforma. $\mathrm{O}$ primeiro requisito é a ativação, a partir do qual se verifica se o vídeo está dentro do mercado possível para anúncios. Isso é importante porque em certos países, como Coréia do Norte, Irã e Cuba, por exemplo, não é legalmente aceito que a plataforma social realize transmissão de propaganda. Nesse caso, se o usuário que acessa o vídeo estiver em um desses países, ele não verá o anúncio. O YouTube disponibiliza uma lista de países que compõem o mercado onde não há restrições legais no site ${ }^{33}$.

Uma vez contemplado nessa lista, o vídeo precisa entrar na categoria apropriada para anúncios. Caso haja conteúdos ofensivos a determinados grupos socioculturais, por exemplo, o site pode julgar que não seja seguro associar uma marca ao conteúdo disponibilizado. Se houver referências a bebidas alcoólicas, jogos de azar ou sensualidade, pode haver indicação de classificação etária para o conteúdo, de modo que os anúncios associados a ele deverão ser exclusivos para adultos. Em qualquer um dos casos supracitados, o autor do vídeo recebe uma notificação do site - que pode ser contestada e revista. Ao cumprir as prerrogativas dessa etapa, passamos para a próxima, a permissão.

Por meio do algoritmo "Entrega dinâmica de anúncios", o YouTube determina a frequência de exibição das peças de propaganda, a fim de atingir o

\footnotetext{
${ }^{33}$ Lista disponível em: https://support.google.com/youtube/answer/1342206?hl=en
} 
público esperado. O algoritmo é composto por vários fatores, como a hora do dia em que os usuários pretendidos estão online, como o vídeo foi encontrado (busca direta ou por meio de listas relacionadas), quantos anúncios são assistidos pelos usuários antes de abandonarem o vídeo, entre outras questões. Isso é sistematizado, a fim de evitar que o público desista do vídeo antes de ser impactado pelo anúncio. Ainda nesse âmbito, há a avaliação do dispositivo utilizado para acessar o conteúdo. À medida que todos os formatos de propaganda disponibilizados pelo YouTube podem ser visualizados em computadores, há algumas limitações para outras mídias. Anúncios de texto de sobreposição, por exemplo, não podem aparecer em aparelhos celulares e os banners laterais não são transpostos para outros sites, como no caso de vídeos do YouTube compartilhados no Facebook.

Cumpridas essas etapas, passamos para a requisição, que consiste na avaliação de compatibilidade entre o vídeo e um anúncio em potencial. Nesse ponto, há vários conteúdos "disputando" por anunciantes, que comportam potencialmente modelos semelhantes de peças publicitárias de determinada(s) marca(s). Há alguns aspectos levados em conta pelo YouTube para decidir onde inserir os anúncios de maneira mais rentável, sendo os principais: a popularidade (número de visualizações), o tempo assistido (é importante, visto que nem sempre o usuário vê o conteúdo até o fim) e as métricas de engajamento (que se referem à quantidade de curtidas, compartilhamentos e comentários nos vídeos).

A partir dessas informações, os vídeos são ranqueados e os mais bem colocados ganham a possibilidade de comportar anúncios. Selecionados os espaços mais rentáveis, o site se encarrega de buscar anúncios apropriados para o conteúdo disponibilizado em vídeo. O YouTube usa o modelo de cascata (Royce, 1970) para fazer a seleção, de modo que é estabelecida uma hierarquia dos modelos de anúncios mais rentáveis aos menos rentáveis. Em ordem decrescente de valor: 1) anúncio em vídeo não ignoráveis; 2) anúncio em vídeo ignoráveis; 3) anúncios de texto (sobreposição); e 4) anúncios gráficos (banners).

Dada essa classificação, há duas formas possíveis de os anunciantes comprarem espaços no YouTube: 1) a compra reservada de anúncio e 2) a compra por leilão. Mais cara, a compra reservada de anúncio é vendida diretamente pela equipe de profissionais da área comercial do Google, com preço tabelado de anúncios premium em vídeos específicos. Geralmente, são conteúdos que se referem especificamente a determinada marca ou conversam com seus 
consumidores. Já as compras por leilão ocorrem de maneira mais genérica, por meio do Google Adwords, utilizado por empresas e marcas no gerenciamento de suas campanhas publicitárias. Nesse sistema, caso um vídeo cative interesse de vários anunciantes, ganha o espaço quem oferecer mais dinheiro para veicular suas peças.

Por fim, fechando o processo, vem a etapa de transmissão, quando os anúncios são efetivamente veiculados na página de exibição do vídeo. No entanto, isso significa um ganho monetário potencial, não automático. Nesse modelo, a existência da publicidade no site não garante que ela gere receita, visto que a circulação do dinheiro depende de vários e complexos fatores que quantificam o impacto das peças. Um texto de sobreposição exibido, por exemplo, pode não gerar impacto (e receita, por consequência) caso não seja clicado por nenhum usuário. De maneira geral, o autor do vídeo e seu canal de distribuição só lucram uma porcentagem do que é pago pelos anunciantes ao YouTube. Em outras palavras, só ganham dinheiro caso o site ganhe dinheiro.

Entretanto, a digitalização dos conteúdos e seu acesso online permite desenvolver diferentes modos de experimentação e de descoberta de conteúdos em torno de uma oferta audiovisual mais variada - e na maioria das vezes gratuita - através de interfaces que promovem usos mais ativos. Por outra parte, o aumento das possibilidades de usos do audiovisual na Rede - se comparada com os meios de comunicação eletrônicos tradicionais apresenta diferentes causas e características. (Santini; Calvi, 2013, p. 175)

Desse modo, é possível dizer que a Cultura da Inernet, a partir da livre circulação e do acesso à informação, gera novas lógicas de consumo de entretenimento audiovisual e, consequentemente, novos modelos de negócios nas plataformas online. A rápida propagação dos conteúdos estimula a automatização dos processos, mas a intervenção de profissionais capacitados ainda é fundamental nas maiores transações publicitárias na rede.

A gratuidade dos produtos audiovisuais na internet é uma realidade para muitos usuários, especialmente os mais jovens, que não têm como hábito pagar para acessar conteúdos (Santini; Calvi, 2013). Para que essa dinâmica sem custos ao usuário permaneça, é preciso que os novos modelos de negócios sejam estimulados. Desse modo, o financiamento das produções é garantido sem repasse direto ao usuário, permitindo criação, distribuição, investimento e retorno aos produtores. $\mathrm{O}$ 
sistema ora apresentado no YouTube se constitui uma alternativa possível de capitalização das novas práticas de consumo audiovisual em tempos de convergência (Jenkins, 2008), que agrega valor ao que há de mais importante em uma produção contemporânea: o seu alcance e o seu potencial de engajamento.

\subsection{A cultura do storytelling: as narrativas das marcas}

Falamos anteriormente sobre a importância da narrativa para a cultura humana e sobre seu caráter social. Durante o desenvolvimento da pesquisa, foi possível perceber também que algumas narrativas se convertem em marcas de grande valor. Essa dinâmica é potencializada com o fenômeno da transmidiação, que orienta o espalhamento dos conteúdos em múltiplas plataformas. Desse modo, a história é fragmentada e o contato com ela a partir de diversas perspectivas e diversos suportes, estimulado.

O estabelecimento dessa conjuntura gera algumas particularidades na produção de conteúdos que já foram discutidas no decorrer desse trabalho. No entanto, cabe atentarmos para o conceito de storytelling das marcas (Massarolo; Mesquita, 2014), um fenômeno estratégico que utiliza o transmedia storytelling (Jenkins, 2008) em multiplataforma para dar identidade e criar relações próximas entre marcas e consumidores em potencial presentes nas redes. Essa estratégia pode ser explicada pelo cenário contemporâneo, onde:

\footnotetext{
As mudanças tecnológicas, comunicacionais, históricas e culturais, que foram geradas pela cultura da convergência afetaram não somente o modelo de negócio da mídia convencional, mas o próprio ambiente de mídia, provocando modificações que prepararam o cenário para o surgimento de novas formas de entretenimento para multiplataformas, que se utilizam principalmente da televisão, internet e dos dispositivos móveis para produção e circulação de conteúdos. (MASSAROLO; MESQUITA, 2014, p. 2)
}

Para que obtenha sucesso, o storytelling das marcas precisa da adesão dos públicos. Apesar do caráter colaborativo dessa metodologia, as ações que a envolvem são realizadas comercialmente, por profissionais especializados. É, portanto, uma estratégia que ganha corpo essencialmente nas redes sociais, onde são compartilhadas narrativas que buscam construir significados positivos em relação ao produto de que tratam. Ao colocar objetos de consumo em Latitudes, por exemplo, as marcas constroem uma identidade acerca de suas mercadorias, 
associando-as a um determinado estilo de vida - dos protagonistas.

O conceito, no entanto, extrapola ações pontuais como as identificadas no capítulo de análise de nosso objeto empírico. Envolve produções de narrativas que atravessem diversas plataformas e se constituam em marcas potencialmente franquiáveis em objetos vendidos ao público consumidor. Massarolo e Mesquita usam o exemplo da saga Star Wars para ilustrar a construção de sucesso de uma marca a partir do transmedia storytelling:

\begin{abstract}
A saga Star Wars, de George Lucas (Episode IV - A New Hope, 1977), estabeleceu as diretrizes do marketing, tal como é concebido pelo storytelling das marcas. A identificação das características do mundo criado para a saga de Star Wars, ou storyworld, permitiu que fosse criada a coesão, consistência e continuidade entre os produtos da franquia cinematográfica, possibilitando que outros produtos derivados da saga original fossem criados, cada qual com diferentes funções, tais como: livros, animações e videogames. Os produtos de uma franquia devem manter sua coerência em relação ao mundo da série cinematográfica original, para que os consumidores tenham uma experiência diferenciada ao transitarem pelas diferentes plataformas em busca de novos conteúdos. (MASSAROLO; MESQUITA, 2014, p. 9)
\end{abstract}

Esse contexto é necessário para chegarmos a um outro modelo de negócio importante na cultura da convergência: as franquias de mídia. Utilizam licenciamentos e merchandising para difundir seu universo ficcional como marca de qualidade, que, se trabalhada de maneira eficiente, agrega valor aos produtos a ela associados. De acordo com Massarolo e Alvarenga (2010, p. 1), esse modelo de negócio vem crescendo consideravelmente nas últimas três décadas, mudando a maneira como as marcas são pensadas, de modo que agora elas vêm “disponibilizando diversas entradas para ser navegado a partir de diferentes mídias e que permitam um profundo envolvimento emocional dos usuários".

Muito comuns na indústria cinematográfica, que a partir dos filmes expandem os universos ficcionais de suas narrativas, as franquias de mídia já existiam na década de 1930, com o Universo Disney. Nesse modelo, além dos filmes com as principais personagens, também era possível consumi-los em histórias em quadrinhos, brinquedos e, posteriormente, parques temáticos. Apesar disso, o negócio ainda não era conhecido pelo nome "franquia", que até os anos 1970 relacionava-se exclusivamente a "operações de varejo (como o Mc Donald's), em que operadores independentes dos mercados locais pagavam pelo direito de fazer 
negócios com uma empresa, ou seja, para poderem compartilhar de uma marca" (MASSAROLO; ALVARENGA, 2010, p. 3).

Somente na década de 1980, o termo franquia começou a assumir um significado cultural e passou a ser usado para descrever tanto os processos de propriedade intelectual corporativa quanto à gestão das formas culturais serializados que dela resultam (linhas de produtos como a franquia Star Trek ou a franquia Star Wars, por exemplo). Nesse período, a franquia de mídia passou a ser entendida como "algo que cria valor através de várias empresas e em múltiplos territórios durante um longo período de tempo." (JOHNSON, 2009, p. 5)". (MASSAROLO; ALVARENGA, 2010, p. 3)

No Brasil, a prática se consolidou a partir do fim da década de 1990, com a Criação da Globo Filmes. A distribuidora, ao se juntar a uma grande produtora audiovisual, a $\mathrm{O} 2$ Filmes, cria uma parceria que "introduz novos conceitos em termos de projetos e lançamento de um filme no Brasil" (LUSVARGHI, 2007, p. 4). A junção desse braço cinematográfico da Rede Globo com produtoras locais inseriu poderosos conglomerados midiáticos no mercado digital, trazendo novas perspectivas para a produção altamente concentrada, até então, em plataformas tradicionais de distribuição.

Desse modo, a criação de narrativas transmídia no contexto nacional se desenvolveu progressivamente nos últimos vinte anos, conforme demonstrado em tópicos anteriores desse trabalho. Atualmente, quase todas as telenovelas produzidas e exibidas no país, por exemplo, contam com extensões online para expansão de suas diegeses. Não é diferente com séries e demais produções ficcionais ou de entretenimento televisivo. São criados, portanto, universos narrativos que passam a se constituir em marcas com credibilidade para venda de espaços de merchandising ou mesmo venda direta de produtos relacionados ao título (passando por roupas, acessórios, itens de decoração e vários outros).

A franquia transmídia entrega um mundo criado como se fosse à imagem e semelhança dos consumidores, mas em si mesma, uma marca é apenas uma ferramenta de comunicação, propaganda e marketing. $\mathrm{O}$ termo 'narrativa transmídia' confere à franquia sua qualidade incomum e transmite os valores agregados à missão da marca. Criar uma missão que satisfaça os interesses da marca significa contar uma boa história que envolva e emocione as pessoas. (MASSAROLO; ALVARENGA, 2010, p. 5)

Não se pode deixar de levar em conta, portanto, o caráter mercadológico da criação desses universos narrativos ligados às tramas ficcionais. A partir do desejo 
de imersão, por parte das audiências, na história desenvolvida, os produtores estimulam a navegação pelos conteúdos em várias plataformas. Esse modelo de negócio garante espaços diversos potencialmente disponíveis para interações comerciais, que passam por plataformas tradicionais e chegam às mídias digitais. Além das narrativas, portanto, também são expandidas as possibilidades de negociações com anunciantes que cada vez mais reconhecem a importância da internet em campanhas publicitárias que se pretendem eficazes diante de determinados públicos.

Assim, apesar de não ser propriamente uma franquia transmídia, principalmente pela falta de maleabilidade em sua narrativa, que até o momento se fecha nas três plataformas definidas na produção, Latitudes opera comercialmente com algumas aproximações desse modelo. Principalmente quando notamos a inserção roteirizada das marcas paceiras.

Por enquanto, é seguro afirmar que Latitudes articula um diálogo com seu público em três plataformas e, portanto, se propõe a capitalizá-las de diversas maneiras. Os anunciantes que são apresentados acreditaram em um modelo narrativo que circulou na internet, na televisão a cabo e nos cinemas. Os produtos relacionados têm, portanto, espaços em todas essas mídias. Talvez não fosse interessante a grandes marcas como a P\&G, Fiat e a Heineken o investimento em uma websérie disponibilizada apenas no YouTube. Quando o modelo narrativo alcança audiências televisivas e telas de cinema, entretanto, por meio de crescimento valorativo com elenco e direção internacionalmente reconhecidos, conforme tratado anteriormente, o negócio pode ficar mais atrativo.

Do mesmo modo, Latitudes é muito mais valiosa comercialmente por não se restringir às mídias tradicionais e explorar novos modelos narrativos na internet. A partir do YouTube, seu alcance passa a abranger, potencialmente, o mundo inteiro, e aqui vale inserir novamente o trunfo do reconhecimento internacional de Alice Braga. Sem dúvida, oferecer aos anunciantes "o melhor de dois mundos" (a segurança das audiências televisivas e das salas de cinema e as inovações possíveis e o alcance global da internet) é uma estratégia mercadológica que merece destaque pelo seu ineditismo no Brasil e pela ousadia nos processos de distribuição.

Apesar disso, o modelo narrativo apresentado até o momento em Latitudes não expande significativamente sua narrativa a ponto de ser possível caracterizá-la como uma franquia transmídia. Um ponto crucial não foi identificado, que se refere 
ao envolvimento dos fãs na construção do mundo ficcional que eleva títulos à categoria de marcas. Não é possível encontras fanfics que explorem possibilidades diegéticas da obra em questão espalhadas pela rede. Do mesmo modo, a própria produção se restringiu aos conteúdos pensados no lançamento e os replicou nas diferentes plataformas propostas. Com exceção dos extras apresentados nos episódios televisionados, a narrativa componente da trama é essencialmente a mesma.

Desse modo, fica claro que a produção contou com a força da narrativa e com o peso deAlice Braga e Daniel de Oliveira, para cativar os seus públicos. Se não há expansões diegéticas significativas, espera-se que algo leve as pessoas a verem repetidamente a mesma história contada em diferentes plataformas. Claro que é impossível não considerar que, muitas vezes, o espectador da televisão ou dos cinemas não está na internet. Por outro lado, quem tem o hábito de fruir conteúdos online, principalmente os mais jovens, talvez não veja televisão ou frequente salas de cinema com assiduidade.

No entanto, seguramente, grande parte do público de Latitudes passou por duas ou mais plataformas em sua experiência com a obra. Esse fenômeno será explorado quando falarmos sobre o conceito de reassistibilidade, no capítulo de análises, mas é importante levantar um ponto nesse momento:

Os espectadores familizarizados com a história de um filme por meio de informações que coletam nas mídias sociais, frequentam as salas na estréia da produção cinematográfica para conferir as informações obtidas e/ou compartilhadas nas mídias sociais. Esse consumidor não se surpreende com a novidade fílmica propriamente dita, pois não depende mais do que encontra no 'real da tela' para obter o reconhecimento de sua expertise. (MASSAROLO; ALVARENGA, 2010, p. 11)

Analogamente, é possível dizer que as audiências que circulam entre as plataformas em sua experiência com Latitudes o fazem pelo prazer de conhecer a obra. Se tornam referências em seus grupos de discussão e dominam não apenas a narrativa, mas também o processo de produção que foi parcialmente revelado na televisão, por meio de conteúdos que não foram disponibilizados nas redes. O fã que teve contato com todas as plataformas que suportam Latitudes é capaz, inclusive, de identificar as discretas mudanças de edição e na trilha sonora que foram feitas na adaptação para o longa metragem.

Desse modo, a repetição tão presente na obra surge como uma estratégia de 
contato com as audiências. Mercadologicamente, é importante lembrar que cada vez que esse contato é estabelecido, ele não se restringe à diegese, mas passa também pelos anunciantes com inserções roteirizadas, que compõem parte dos conteúdos apresentados. É fundamental, enfim, destacar que o modelo de produção e comercialização de Latitudes opera no sentido contrário ao tradicional, no qual a publicidade é feita especificamente para uma mídia. De outra maneira, as marcas associadas ao título são reforçadas em todas as plataformas nas quais ele circula. Afinal, a método legalmente possível e efetivo de um patrocinador ter seu anúncio circulando eternamente sem precisar pagar mais por isso é por meio do product placement, estratégia empregada por Latitudes que para adequar seus conteúdos aos modelos de produção e distribuição adotados pelo projeto transmídia. 


\section{CAPÍTULO 6: LATITUDES ENTRE FORMATOS E GÊNEROS}

A discussão acerca dos gêneros para essa pesquisa é importante por duas razões centrais: 1) compreensão dos processos realizados por produtores e emissoras de televisão e 2) construção teórica no campo dos estudos televisuais. Primeiramente, a classificação genérica assume relevância ao orientar a distribuição dos conteúdos na grade horária televisiva. Distribuir os gêneros em horários que agradem mais a determinados públicos é estratégico para alcançar índices satisfatórios de audiência, uma espécie de "caminho seguro" a seguir. Apesar de não haver consenso sobre os critérios definidores de gênero - ora é privilegiada a questão temática, ora os dispositivos tecnológicos envolvidos (Mungioli, 2012) -, o gênero é um conceito valioso para a manutenção mercadológica audiovisual. Neste tópico, discutimos as diferenças encontradas nos conteúdos de Latitudes em seu formato para o YouTube e para a televisão, bem como as estratégias narrativas identificadas em nosso objeto de análise.

\subsection{Gêneros e Discursos no estudo de Latitudes}

No campo da Comunicação, a compreensão dos gêneros é importante por revelar que tipos de produções culturais são realizadas e de que maneira elas mediam relações sociais incorporadas às matrizes culturais e dispositivos tecnológicos (Martín-Barbero, 2001). Mesmo o gênero ficcional, que nos interessa para a análise desse trabalho, se configura como um instrumento importante de percepção da realidade. Desse modo, o estudo dos gêneros podem evidenciar questões embutidas na vida "real" das comunidades:

(...) os gêneros são, entre outras coisas, modelos de construção e de compreensão do mundo "real" e do mundo ficcional que se imbricam na composição ou no reforço de ideologias, socialidades e imaginário popular. (MUNGIOLI, 2012, p. 100)

Sob essa perspectiva, os gêneros se relacionam intimamente com os processos comunicacionais da sociedade, ao se associarem às narrativas produzidas em suas diversas esferas. Eles estão imersos em nossa cultura e, portanto, mediam nossa concepção de mundo. Abordados a partir dessa ótica cultural, os gêneros passam de estratégias mercadológicas a marcadores simbólicos de uma sociedade em transformação na era da convergência. 
O princípio para a compreensão da teoria dos gêneros do discurso postulada por Bakhtin (2003) localiza a comunicação como resultado da realização de enunciados concretos. Desse modo, os gêneros do discurso são resultados de condições sócio-históricas e não de enunciações individuais daquele que fala ou escreve, embora estas últimas sejam a matéria prima dos referidos gêneros. De acordo com Mungioli (2012, p. 104), os gêneros do discurso "dependem de todo um contexto sociocultural para se concretizarem como modelos de expressão de uma comunidade de falantes ou de escritores".

Não estabelecemos como objetivo desse trabalho uma classificação dos gêneros do discurso presentes em Latitudes, principalmente considerando o caráter plural que eles podem assumir quando inseridos em cada uma das esferas das relações humanas (econômica, social, cultural, histórica...), que pressupõem classificações diferentes de gêneros "típicos" para determinado contexto de materialização do discurso.

Entender, portanto, as narrativas estabelecidas na contemporaneidade e seus gêneros nos ajuda na compreensão das transformações técnicas e culturais da sociedade.

(...) sob essas formas quase infinitas, a narrativa está presente em todos os tempos, em todos os lugares, em todas as sociedades; a narrativa começa com a própria história da humanidade; não há em parte alguma povo algum sem narrativa. (BARTHES, 2009, p. 19)

Para Barthes (2009), a narrativa, portanto, não é apenas o desencadeamento de ações dramáticas, mas uma série de unidades funcionais que dão sentido à história. Buscando compreender a construção narrativa a partir de sua estrutura e em contato direto com suas formas de recepção (e fruição) Eco (1994) postula que as narrativas podem ter dois níveis: o primeiro estabelecido pela experiência superficial de contato com as obras e o segundo, a partir da fruição estética carregada de significados embutidos nas unidades funcionais - como a escolha recorrente da cerveja Heineken pelo personagem José em Latitudes. Ao pedir uma Heineken durante o almoço em Veneza, por exemplo, o produto adquire valor indicial sobre o estilo de vida do personagem - moderno, contemporâneo, cosmopolita. Uma cerveja, desse modo, não é apenas uma cerveja.

Além dos conteúdos propriamente ditos, os formatos, em estreita correlação com os gêneros estabelecidos na produção de uma obra fíccional 
também são ferramentas importantes para a compreensão do mundo. Ao ser lançada na televisão, cinema e YouTube (portanto, série, longa metragem e websérie, respectivamente), Latitudes se torna um objeto valioso para o entendimento de uma realidade que se adapta a modelos culturais em transformação. É importante lembrar o que dissemos no início desse capítulo: o estabelecimento dos gêneros do discurso só é possível a partir do contato com a enunciação materializada, em sua expressão. A partir dessa etapa do trabalho, buscaremos identificar de que forma os discursos em Latitudes são efetivados, a partir das realizações audiovisuais, e o que eles nos revelam sobre novos modelos de produção, distribuição e consumo de conteúdos audiovisuais.

\subsection{Injunções sociais e plasticidade dos gêneros}

Em uma análise da obra de Todorov (2011), Adam (1985) propõe a seguinte relação para a composição das narrativas: Estado Inicial - Transformação - Estado Final. É a partir de tensões que levam a estados transformadores que a trama se desenvolve. Ou seja, a narrativa nunca é uma mera organização de eventos que compõem uma história; é, na verdade, uma cadência de acontecimentos repletos de intencionalidade e objetivos. É na compreensão desse ponto que a análise estrutural da narrativa em Latitudes, sob essa perspectiva teórica, se faz tão importante. A partir dessa certeza, nos propusemos à averiguação de (novas) formas de contar histórias possibilitadas pelo desenvolvimento técnico contemporâneo no contexto da convergência

Como posto anteriormente, Latitudes conta a história do casal Olívia e José, que vive experiências de encontros e separações em várias cidades do mundo, em uma rotina de viagens constantes e hotéis ao redor do mundo. A obra trata, claramente, de um conto moderno, com conflitos e dilemas para que as personagens consigam viver uma história de amor. Ela própria repleta de contradições e injunções de um mundo globalizado. O projeto ficcional foi realizado pela produtora Los Bragas, com apoio da P\&G, Heineken e Fiat e está dividido em oito webisódios disponíveis no canal do Projeto Latitudes ${ }^{34}$ no YouTube, oito episódios transmitidos pela TNT e um longa metragem.

\footnotetext{
${ }^{34}$ Disponível em: https://www.youtube.com/user/Latitudesfilme
} 
No decorrer do trabalho, já apontamos que a nave-mãe da obra ficcional Latitudes está na internet, no formato de uma websérie, entre os episódios disponíveis no YouTube. Ou seja, todo o eixo central que concentra a trama está arquivado online e é a partir desse ambiente que a narrativa se espalha para as outras plataformas (televisão e cinema) em outros formatos (série e longa metragem, respectivamente). A identificação da nave-mãe permite que se delimite a análise a ser feita nesse capítulo, que partirá dela (da nave-mãe) para sua adaptação à plataforma televisiva.

Escolhemos esse modelo de transição (entre internet e televisão) para análise devido a alguma questões centrais. A primeira delas se relaciona à serialidade. Consideramos mais vantajoso o estudo entre os dois formatos seriados de Latitudes, por possibilitarem mais pontos de comparação - além de serem efetivamente os formatos mais expressivos e com mais repercussão midiática da narrativa. A segunda razão se debruça sobre a escassez de mudanças na adaptação para o longa metragem. O filme exibido nos cinemas é praticamente uma montagem da websérie disponível no YouTube. Conversando com essa questão, temos a terceira razão, que toca as grandes adaptações narrativas e estéticas do conteúdo televisionado do projeto transmídia. Sequências novas são inseridas de maneira inédita na televisão, revelando metanarrativas sobre a realização da obra inexistentes em outras plataformas - acreditamos, portanto, que elas carecem de análise. Por fim, não podemos deixar de levar em conta a importância que a TV assume conceitualmente nesse trabalho. Afinal, é a partir das transformações dessa plataforma que projetos transmídia como Latitudes puderam se desenvolver. Desse modo, centraremos nossa investigação nesse capítulo entre os formatos websérie e série de televisão.

No ambiente online, a história se desenvolve em uma cadência "temporal" de fatos que nunca se afastam do seu universo muito bem delimitado enquanto ficcional. O conteúdo exibido pela televisão é, desse modo, um meio de estreitar as relações do público com as etapas de produção de Latitudes e de reapresentar os personagens com mais profundidade, de maneira que o espectador retorne à narrativa ficcional com novas perspectivas interpretativas. É, portanto, uma estretégia de redirecionamento dos indivíduos com novos e complexificados olhares à história desenvolvida anteriormente na nave-mãe. Essa renovação do olhar da audiência ocorreu por meio de conteúdos criados especificamente para 
compor os episódios televisionados, que são intercalados com a trama ficcional no decorrer do desenvolvimento da diegese.

\subsection{Alguns elementos da estética e produção online}

$\mathrm{Na}$ atualidade, como foi apresentado anteriormente, o distribuição e o consumo de conteúdos televisivos não se restringe ao televisor. Há diversas maneiras de acessar a programação por outros dispositivos. Uma Smart $T V^{35}$, uma Apple $T V^{36}$ ou mesmo um videogame, por exemplo, garantem conexão do aparelho à internet e a aplicativos de transmissão em streaming, entre outras funções. Além desses devices, é possível fazer download de programas televisivos pelo computador e visualizá-los no aparelho de TV a partir de cabeamento, DVDs ou USB.

Ademais, de acordo com estudos de Lopes e Mungioli (2014, 2015), o acesso a plataformas on demand vem aumentando no Brasil, de maneira que a procura por novos sistemas de consumo e oferta de conteúdos são crescentes. Apesar disso, o fluxo tradicional televisivo ainda concentra muito poder no mercado midiático nacional. Isso se deve a dois fatores principais que constituíram essa pesquisa até o presente momento.

O primeiro se refere ao hábito de consumo da programação, calcado na grade horária televisiva, devido à constituição do mercado de mídia brasileiro - com altos níveis de concentração e privilégios de grandes emissoras. De certa maneira, as redes de televisão estabelecidas no país atuaram contra a penetração de plataformas digitais, proibindo a circulação de seus conteúdos, por exemplo (vide a longa ausência da Globo nas redes sociais, fato que mudou recentemente). Diante, no entanto, de um caminho irreversível de abertura midiática, esse cenário vem mudando. Hoje, é cada vez mais comum ver parcerias entre as emissoras e plataformas sociais, além da disponibilização da programação integral (e com conteúdos exclusivos) na internet.

Entretanto, outra questão que toca o estabelecimento definitivo do on demand no Brasil diz respeito precisamente à conexão de internet possível no país.

\footnotetext{
${ }^{35}$ Aparelhos de televisão com conexão à internet integrada, que permite instalação de aplicativos de acesso a jogos, Videos on Demand e programação interativa.

${ }^{36}$ A Apple TV é um reprodutor de mídia digital que pode ser acoplado a um televisor comum. Basicamente, o aparelho garante à televisão tradicional as funções de uma Smart TV, por meio da conexão à internet.
} 
Fora dos grandes centros urbanos brasileiros, a banda larga é oferecida, muitas vezes, de maneira precária. Mesmo com o barateamento das tecnologias de conexão, em um país onde milhões de pessoas ainda vivem abaixo da linha da pobreza, o acesso universal a computadores ou tablets, por exemplo, ainda está longe de ser uma realidade. Além disso, vemos operadoras de internet prestando serviços sem qualidade de navegação e cobrando valores impossíveis a grande parte da população ${ }^{37}$.

No caso brasileiro, uma banda larga abrangente em nível nacional é ainda um sonho distante - a realidade concreta continua dominada pela televisão aberta e sua meia dúzia de canais distribuídos de norte a sul -, embora as TVs por assinatura venham nos últimos anos se popularizando, estamos longe de uma oferta mais ampla, dos pacotes mais básicos ou dos canais premium. Segundo dados oficiais da Anatel, o número total de assinantes no Brasil é de pouco mais de dezesseis milhões, o que equivale a uma densidade por domicílio de $28,1 \%$. Nos Estados Unidos, em torno de $43 \%$ dos domicílios possui serviço de TV por assinatura, o que representa 56 milhões de assinantes. (SILVA, 2014, p. 242)

Apesar disso, não é possível deixar de considerar essas novas perspectivas de distribuição e consumo como uma potencialidade latente na produção ficcional de audiovisual no Brasil. Dentro desse cenário, as séries ocupam lugar de destaque na realização de conteúdos, deixando para trás formatos tradicionalmente produzidos no país. Para entender a complexidade desse fenômeno, Silva (2014) propõe três condições centrais: forma, contexto e consumo. Vamos a elas.

A primeira delas se refere à forma, ou a novos modelos narrativos criados a partir da convergência midiática, ou à adaptação de gêneros consagrados, como o melodrama, policial ou sitcom. De acordo com Pearson apud Silva (2014), o surgimento do escritor/produtor em lugar de destaque no processo de criação, em papel análogo ao do diretor de cinema ou da telenovela, é fundamental na compreensão desse fenômeno. Desse modo, grandes nomes da filmografia ou da televisão vêm sendo chamados para compor a equipe de séries produzidas para a TV a cabo ou mesmo diretamente para a internet (Jost, 2012; Ezquenazi, 2010). Vale ressaltar que mesmo no caso de produções para a pay tv, a internet surge como

\footnotetext{
${ }^{37}$ Em uma breve pesquisa com a empresa de telecomunicações NET em maio de 2016, foi possível constatar, por exemplo, que o serviço de internet mais barato (15 MB) oferecido em São Paulo tem o custo de $\mathrm{R} \$ 99,00$ mensais. Por menos que isso, não é possível acesso à banda larga pela operadora. Em um país onde o salário mínimo é $\mathrm{R} \$ 880,00$, só o gasto com internet (levando-se em conta o pacote mais barato), representaria $11,25 \%$ do rendimento mensal de milhões de famílias brasileiras.
} 
mediadora, visto que a fruição muitas vezes acontece via download ou streaming em horários alternativos à exibição original na grade horária.

Desse modo, a credibilidade de profissionais consagrados nas plataformas tradicionais é repassada para realizações de caráter mais experimental, que ousam ao contar histórias fugindo de clichês ou modelos narrativos costumeiros.

\begin{abstract}
Dentro de um circuito crítico, que atribui relevância artística para as séries, a definição de uma marca autoral, como índice valorativo, ajuda a garantir o investimento em obras mais radicais narrativamente. Nesse contexto, a televisão segmentada passa a ser o lugar por excelência das séries "complexas" - para lembrar a recorrente categoria de Mittel (2006) -, tornando-se produtos culturais intensamente presentes também nos circuitos digitais de troca de arquivos e consumo online. (SILVA, 2014, p. 244)
\end{abstract}

Esse cenário se deve ao estabelecimento da televisão como espaço possível de qualidade artística (Greco, 2013), possibilitando a emergência de séries com valor técnico de produção. Esse valor se deve a uma característica peculiar desse meio em relação ao cinema, a cacofonia. A programação televisiva, tal qual a disponibilizada pela internet, deve ser capaz de prender a audiência fora de um ambiente, digamos, favorável, como as salas de cinema se constituem. Em meio a várias opções de canais e intervalos comerciais (ou possibilidades infinitas de navegação em plataformas online, em um ambiente cada vez mais multitarefas), manter a atenção do espectador exige inovações formais da produção audiovisual.

A segunda condição, o contexto, se refere principalmente às condições que permitem novas formas de consumo no que o autor define como cultura das séries (Silva, 2014). Para iniciar a discussão, é válido retomar o que foi esclarecido no primeiro capítulo desse trabalho, quando tratamos da hipertelevisão (Scolari, 2014): não é possível falar do fim da televisão no mundo e menos ainda em um país como o Brasil. O que se propõe aqui é entender que novas ferramentas estão em jogo para mediar o consumo da produção televisiva e como elas alteram a realização de conteúdos.

Nas últimas décadas, a partir da popularização de tecnologias como DVD e Blu-ray e, mais recentemente, possibilidade de download de conteúdos, a indústria do entretenimento vem ofertando alternativas ao fluxo tradicional da programação e criando um público cada vez mais habituado ao on demand. Temos uma audiência crescentemente mais interessada em acompanhar séries no momento de exibição em seus países de origem, via streaming, ao invés de esperar o lançamento no 
Brasil. Além disso, o hábito de fazer download via torrent e assistir temporadas inteiras fora da cronologia estabelecida pela grade de programação vem se popularizando. Nesse contexto, a troca de arquivos via plataformas de compartilhamentos online se sobressai e, de certa maneira, substitui a progressivamente rara compra de mídias com os conteúdos televisivos em lojas especializadas. Martel (2012) e Castells (2009) discutem essa mudança no consumo, que leva cada vez menos em conta os conteúdos físicos e é estimulada pela sua digitalização.

Desse modo, com a internet vamos gradativamente deixando de falar de exportação, para falar de circulação de produtos televisivos. Num primeiro momento, pode parecer a simples mudança de um paradigma industrial do capitalismo (com os bens materiais ocupando o grosso dos proventos) para um capitalismo pós-industrial, cognitivo, em que os bens simbólicos e culturais circulam transnacionalmente com mais fluidez, num circuito virtual extremamente complexo e intrincado. Não se pode adjurar aqui a superação - pelo menos não imediatamente, como os dados culturais e econômicos indicam - de um modelo de televisão nacional e em fluxo, para um modelo transnacional e em rede. (SILVA, 2014, p. 247)

Somado a esse processo, observamos a difusão de narrativas transmídia ou transmedia storytelling (Jenkins, 2008) distribuídas em múltiplas plataformas, que expandem os universos ficcionais para além da televisão e instigam as audiências a buscarem conteúdos na internet (principalmente, nos modelos de convergência estabelecidos no Brasil), estimulando a criação de um público cada vez mais habituado ao consumo nas redes. Seja por meio de conteúdos oficiais, como hotsites, blogs de personagens, quizzes, aplicativos etc, ou por meio da incitação da atuação em redes sociais, reverberando os conteúdos ficcionais, a indústria de entretenimento está presente nesse filão.

Mesmo a TV paga se insere de maneira progressiva nesse cenário, a partir de serviços de assinatura de conteúdos on demand, como o Muu, HBO GO, Telecine Play, Now e Claro TV, entre vários outros. São, sem dúvida, “o esforço que os conglomerados televisivos estão encampando para atender a essas novas demandas de consumo" (SILVA, 2014, p. 247). Essa conjuntura gera discussões interessantes acerca da memória, visto que a programação, mesmo diante da efemeridade da TV tradicional, fica disponível em uma espécie de repositório, tal qual ocorre em plataformas digitais, como o YouTube.

Essas novas formas de acesso aos conteúdos, como falamos anteriormente, 
direcionam à cultura das séries, estimulando novas atuações da audiência - o que nos leva ao terceiro ponto levantado por Silva: o consumo. Esse aspecto é relevante por trazer à luz do debate a agência dos fãs das séries e dos conteúdos disponibilizados a partir das novas possibilidades das tecnologias digitais. Diferentemente da audiência comum, os fãs atuam por meio de eixos temáticos específicos, movimentando conteúdos nas redes e interagindo entre si (Costello; Moore, 2007).

Essa nova maneira de atuação do público diminui a distância entre realizadores e consumidores das produções ficcionais. Observamos perfis pessoais de fãs em fóruns de discussões que debatem publicamente as temáticas dos conteúdos televisivos, de maneira que a transformação do hábito se revela (Livingstone, 2004; 2005). Desse modo, o público vem sendo considerado de maneira ativa no entendimento dos pontos positivos e negativos da programação, estimulando inclusive as emissoras de TV a buscarem interações produtivas, por meio de conversas oficiais estabelecidas nas redes (Lopes; Mungioli, 2015). Acabase estabelecendo uma relação simbiótica entre produtores e audiência, de maneira que as duas instâncias se retroalimentam. À medida que os espaços qualificados de fãs geram buzz acerca de determinada produção, eles ganham legitimidade quando reconhecidos pelas grandes emissoras ou produtoras e contam com a divulgação em meios massivos.

Os estudos de fãs vêm revelando uma crescente pertinência no atual ambiente comunicacional em que as audiências se fragmentam e se diversificam (Lopes, 2011). O engajamento (conceito a ser explorado adiante) parece ter ocorrido, em etapas iniciais, apenas em função de curtir, seguir e ser seguido, progredindo para a etapa seguinte, de criação de conteúdos também referida como Conteúdo Gerado pelo Usuário (CGU). A partir dessa perspectiva, é possível afirmar que talvez nunca tenhamos observado, como no momento atual, tão intenso fluxo de conteúdos que atravessam diferentes mídias e que são reinventados a partir de cada uma delas (...). (LOPES; MUNGIOLI, 2015, p. 17)

É possível observar, portanto, a indissociabilidade entre produção, distribuição e consumo. Quando as bases tecnológicas de distribuição se alteram, os dois outros vértices irão necessariamente passar por transformações análogas. É a materialidade do signo, submetido às injunções sociais de seu tempo, vista na prática. É nesse contexto que Latitudes se localiza, como uma experimentação no universo de possibilidades das narrativas em tempos de múltiplas plataformas, 
dispositivos digitais e cenário político de democratização da produção ficcional no Brasil.

\subsection{Latitudes entre narrativas e linguagens}

Em uma análise mais detalhada de Latitudes, é possível observar várias vozes marcando os discursos das personagens. Olívia carrega em sua construção a idéia de mulher independente e com uma carreira de sucesso, que não liga para sentimentalismos. Isso fica muito claro logo no primeiro webisódio/episódio da websérie/seriado (ou primeira sequência do longa metragem), quando Olívia, após passar a noite com José, recebe ligações cobrando sua presença em compromissos profissionais (uma delas inclusive em inglês, o que evidencia o caráter global do trabalho da personagem). Uma das justificativas usadas pela personagem é "uma dor de cabeça que não vai embora" da qual Olívia reclama enquanto a câmera foca José dormindo, em uma clara alusão entre o fotógrafo e a dor de cabeça da editora de moda.

Por outro lado, no Quarto Destino - José Ignacio, a personagem mostra outro lado de sua construção. Já envolvida por José, ela fica enciumada por imaginar que o fotógrafo desliga o telefone quando ela chega ao quarto, o que não condiz com a personagem fria e sem envolvimentos emocionais construída até então. Nesse ponto, Olívia acha que ele ficou constrangido ao falar no celular em frente a ela, e, após uma discussão, ela se irrita por questões que revelam a impessoalidade do relacionamento, como não saber sequer onde é a casa do fotógrafo.

José, da mesma maneira, carrega em si uma série de vozes que entram em conflito e se relacionam. No Segundo Destino - Londres, ele se mostra um homem confiante e conquistador. Propõe subir para o quarto de Olívia e tem como certo que eles voltarão a se encontrar no futuro, apontando para ela sinais disso em seu comportamento galanteador enquanto os dois tomam drinks no bar de um hotel. Ambos aparentam ser solteiros e desimpedidos, o que é contestado algumas vezes e definitivamente rechaçado no Quinto Destino - São Paulo. Nesse episódio, José aparece conversando com outra mulher, o que já causa estranheza pois, até então, todas as cenas eram compostas apenas por ele e Olívia. Em São Paulo, o fotógrafo é mostrado pela primeira e única vez em sua casa, com sua namorada até então. 
Nesse ambiente, é revelado um personagem quieto, quase inseguro, que não sabe quais caminhos seguir ou decisões tomar. Enquanto, com Olívia, José toma todas as iniciativas e tenta contornar sua personalidade controladora, com a namorada ele estabelece uma relação mais resignada, ao contar-lhe sobre o caso com a editora de moda.

Enquanto os episódios online concentram uma narrativa presa à diegese, estritamente ficcional, na televisão, Latitudes assume um caráter mais metanarrativo, a partir do qual são revelados os bastidores da produção, além da construção subjetiva das personagens e da trama. Os episódios televisionados assumem, nesse sentido, o papel de revelar a construção do interdiscurso (Gregolin, 2005; Orlandi, 2009) - intrínseca no discurso de cada personagem e em suas facetas múltiplas.

Desse modo, os extras de produção adicionados aos episódios televisionados provocam alguns deslocamentos na produção de sentido a partir da ruptura de estatutos pragmáticos ao tornarem mais nebuloso o eu-fictício da narrativa e estabelecerem, em certa medida, um discurso testemunhal de realização da obra (Hamburger apud Mungioli, 2012). Jost (1997) coloca a importância do sujeito da enunciação na construção (ou desconstrução) da ficcionaliade.

Se, por um lado, esses procedimentos imprimem à linguagem televisual a marca da interação e da cocriação, por outro, introduzem no mundo da ficção uma ancoragem na realidade e no cotidiano muito mais próxima da imitação ("como se") que da representação ("como"), uma vez que de certa maneira o euorigem-fictício (HAMBURGER, 1986) sofre uma inflexão em direção do autor daquela proposta de encaminhamento de ação ou da trama. (MUNGIOLI, 2012, p. 112)

Desse modo a confluência de vozes na construção do discurso das personagens é uma característica que marca a produção de sentido na narrativa televisual de Latitudes. Diversos processos de realização são revelados e retiram o véu de ficcionalidade, identificando a obra como um produto da indústria cultural. É um processo de diálogo com as audiências e de concessão de mais informações sobre a composição de Latitudes.

Esse recurso fica muito claro no primeiro destino - Paris/ENSAIO ${ }^{38}$, quando são mostrados extras da produção do episódio inicial da série. O

\footnotetext{
${ }^{38}$ Para esse capítulo, assume-se que sempre que houver "/ENSAIO" ao final de um episódio, trate-se do conteúdo televisionado, mostrando os extras da produção.
} 
desenvolvimento desse destino número um é fundamental por representar, idealmente, o primeiro contato da audiência com Latitudes, sendo um momento crucial para o estabelecimento subjetivo das personagens e do "clima" da obra. Desse modo, o episódio se desenvolve com muitas intervenções dos bastidores, em uma estrutura diferente da websérie.

Na série transmitida pela televisão, antes da exibição de várias das cenas que compõem a trama ficcional, é feita uma intervenção explicando a situação, mostrando ensaios dos atores ou dicas do diretor. O Primeiro Episódio Paris/ENSAIO, por exemplo, começa da seguinte maneira: imagens de garrafas vazias de bebidas e roupas jogadas em um quarto de hotel, onde um homem está deitado. À medida que as imagens são apresentadas, é feita a seguinte narração em voice over: "Em diferentes partes de uma suíte de hotel, garafas de champagne, cerveja, água mineral, tudo vazio. Na penumbra, um homem adormecido na cama. José, 35 anos, dorme pesado". Trata-se de um trecho do roteiro descrevendo o que, no YouTube, é apenas mostrado em cena. Em seguida, são exibidas imagens dos bastidores, nas quais são revelados detalhes sobre as personagens (é dito a Alice Braga que a sua personagem se maquia sem ajuda de um profissional, por exemplo), além de um ensaio dos atores com as falas do episódio. Em seguida, as cenas ensaiadas e descritas são exibidas, e os episódios televisionados seguem esse ritmo da trama sendo intercalada com extras que revelam os detalhes de produção da própria trama em curso.

Quanto à construção das personagens, um ponto muito esclarecedor no Primeiro Destino - Paris/ENSAIO acontece com uma intervenção da atriz Alice Braga durante a passagem de uma das falas de sua personagem, Olívia. Ao passar o texto do roteiro, as falas das personagens eram as seguintes:

José: Por que você não me acordou?

Olívia: Nem pensei nisso.

Ao ler o texto, durante o ensaio repercutido no episódio televisionado, Alice Braga sugere que mais que "nem pensei nisso", a personagem poderia falar que "achei melhor não". Percebemos, portanto a diferença de sentido estabelecida: à medida que a frase original atribuída a Olívia denota desinteresse, a sugestão de Alice Braga aponta para uma resolução. Ao exibir a sequência seguinte, com o diálogo já inserido na narrativa ficcional, percebe-se que a mudança sugerida pela atriz foi acatada pela produção. Desse modo, fica claro que a construção das 
personagens não emana de um diretor ou roteirista individualmente, mas acontece coletivamente (respeitando-se, claro, os limites da esfera produtiva), mostrando claramente a polifonia e a interdiscursividade envolvidas no processo.

Nas obras polifônicas, o autor continua presente, mas atua como o regente do grande coro de vozes que participam do processo dialógico. Mas esse regente é dotado de um ativismo especial, rege vozes que ele cria ou recria, mas deixa que se manifestem com autonomia. (BEZERRA, 2005, p. 194)

Ou seja, o autor, na figura do diretor Felipe Braga, atua como esse "regente do grande coro", sujeito a intervenções internas e externas a todo o momento. As vozes surgidas anteriormente ou no momento do ensaio final da produção são manifestadas e levadas em consideração para a construção das personagens, em

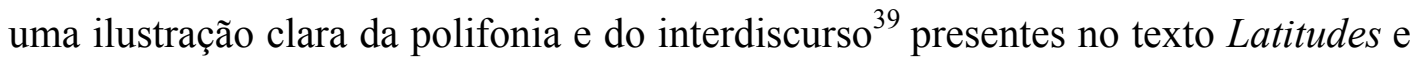
também do caráter coletivo de construção dos diálogos a serem encenados. O interessante é perceber que, enquanto esses conceitos são colocados por trás das cortinas na maioria das produções ficcionais, em Latitudes, eles são escancarados para o grande público.

Apoiados nessa perspectiva, podemos observar a polifonia presente na construção discursiva de Latitudes. Além de sua concepção ser necessariamente uma confluência de vozes durante o momento de criação autoral, elas alcançam um "segundo nível polifônico" quando sua construção é apresentada em consonância com uma coletividade. O trabalho ora disponibilizado no YouTube é reapresentado na televisão como construção coletiva. Percebamos que:

A voz do herói sobre si mesmo e o mundo é tão plena como a palavra comum do autor; não está subordinada à imagem objetificada do herói como uma de suas características, mas tampouco serve de intérprete da voz do autor. Ela possui independência excepcional na estrutura da obra, é como se soasse ao lado da palavra do autor coadunando-se de modo especial com ela e com as vozes plenivalentes de outros heróis. (BAKHTIN, 2008, p. 03)

\footnotetext{
${ }^{39}$ Consideramos neste trabalho a definição de interdiscurso apresentada por Eni P. Orlandi, in Análise de discurso: princípios e procedimentos, (2009, p. 31), segundo a qual o interdiscurso se estabelece a partir das relações entre memória e discurso. O interdiscurso é "(...) definido como aquilo que fala antes, em outro lugar, independentemente. Ou seja: é o que chamamos de memória discursiva: o saber discursivo que torna possível todo dizer e que retorna sob forma do préconstruído, o já-dito que está na base do dizível, sustentando cada tomada de palavra"
} 
Se esse fenômeno é evidente quando se fala em concepções autorais tradicionais, nas quais a obra é creditada supostamente a um só criador, ele é potencializado em Latitudes. Com seus processos de produção revelando uma criação latente e inclusiva mesmo nos momentos finais, as personagens ganham voz própria de maneira muito mais evidente

A televisão, portanto, procura elucidar esses "mistérios" que levam a uma relação mais íntima com a obra. Extras que constroem uma metanarrativa de Latitudes e criam novas referências para que a audiência retorne à diegese com outros olhares e perspectivas. Nesse ponto, o trabalho irá analisar as estruturas narrativas em duas das três plataformas nas quais Latitudes foi exibida: a internet e a televisão. Esse estudo é necessário por conta da quebra da narrativa que ocorre na plataforma televisiva, a fim de compreender as diferenças formais de Latitudes nos episódios online e nos episódios televisionados e apontar as estratégias utilizadas na inserção de conteúdos extras da produção intercalados ao desenvolvimento da trama veiculada na TV paga.

\subsection{Entrecruzamentos estéticos das plataformas: a (des) construção de temporalidades e ritmos}

Uma das transformações mais evidentes que Latitudes passa em sua transposição do ambiente online para a televisão diz respeito ao ritmo da narrativa. Para começar: a média de tempo dos episódios disponíveis no YouTube é de quinze minutos e trinta segundos, enquanto na televisão eles duram cerca de vinte minutos (ao todo, cada episódio conta com vinte e cinco minutos na programação da TNT, subtraindo-se o tempo de comerciais, sobram esses cerca de vinte minutos da obra ficcional). Essa quebra na temporalidade é resultado de uma lógica que exige da TV programações mais longas para seu encaixe na grade horária e venda de anúncios. $\mathrm{Na}$ plataforma online, por outro lado, o ritmo é outro, com narrativas mais curtas devido à grande propensão de dispersão das audiências entre vários links, páginas e abas disponíveis durante o tempo de fruição.

O que se passa na obra que a altera estruturalmente dessa maneira? A princípio, deve-se falar do ritmo da narrativa. $\mathrm{Na}$ internet, vemos webisódios de Latitudes cujas tramas transcorrem sem interrupções. O destino das personagens em 
cada episódio é apresentado e a história se desenvolve sem maiores explicações externas. Espera-se que a audiência acompanhe o desenvolvimento da narrativa, ela segue seu curso respeitando os limites da diegese. São episódios mais curtos e acelerados, que buscam assimilar o tempo de atenção característico do espectador online, reduzido se comparado ao do público da televisão.

Já na TV, a estrutura dos episódios é outra. A todo o momento, a voz da produção entra em cena, em estratégia de voice over ou com a inserção de sequências inteiras de ensaios, conversas entre os atores (Alice Braga e Daniel de Oliveira) e o diretor (Felipe Braga), descrição de personagens ou ambientações de cenas (principalmente dos luxuosos hotéis que serviram de locação para os episódios ao redor do mundo). De maneira geral, esses conteúdos extras com os bastidores da produção precedem a cena à qual eles se referem. Ou seja, se Alice Braga e Daniel de Oliveira aparecem em estúdio passando falas como se estivessem na cama de um hotel veneziano, em seguida é mostrada a cena de Olívia e José desenvolvendo o mesmo diálogo na cama de um hotel veneziano.

Percebe-se, desse modo, sobre o tempo da narrativa, que: “... o leitor é obrigado a 'mudar de marcha' (...) o tempo do discurso é o resultado de uma estratégia textual que interage com a resposta dos leitores e lhes impõe um tempo de leitura" (ECO, 1994, p. 63). A estratégia utilizada na televisão é, portanto, claramente diversa daquela empregada na exibição original de Latitudes, na internet. A narrativa online segue um curso mais dinâmico para prender e cativar a audiência, o que faz sentido quando se leva em conta que esse é pretensamente o primeiro contato com o público - além do que já se falou a respeito do tempo de atenção na internet. A televisão, por sua vez, cumpre o duplo papel de explicitar os bastidores da produção e acrescentar conteúdos à plataforma original online. Mesmo sem expandir o universo ficcional (Jenkins, 2008), a TV dá conta de acrescentar repertório acerca da narrativa ao espectador.

A transposição da internet para a televisão traz mudanças narrativas que causam alterações no desenvolvimento da trama, principalmente referentes ao seu ritmo. Além disso, novos elementos que são acrescentados, na forma de extras de produção, que revelam a construção da ficcionalidade em Latitudes com a apresentação de detalhes dos bastidores e informações acerca da produção. 
A partir da análise minuciosa de todos os episódios transmitidos pelo canal pago $\mathrm{TNT}^{40}$, foi possível estabelecer seis categorias que tipificam as inserções de conteúdos extras de produção em Latitudes. Elas são encontradas várias vezes no decorrer dos episódios e formam um padrão que será utilizado posteriormente para quantificar as estratégias de inserção dos extras de Latitudes na série televisionada.

\section{a) Descritiva}

A categoria descritiva geralmente ocorre por meio de uma intervenção em voice over na narrativa ficcional com uma descrição do diretor Felipe Braga ou de algum dos atores (Alice Braga ou Daniel de Oliveira). A categoria descritiva cumpre a função de ambientar a trama, criando o "clima" previsto para as cenas.

É a partir dela que a produção descreve detalhadamente os quartos dos hotéis nos quais o casal protagonista se hospeda ou os bares frequentados por eles. Por vezes, também são descritos os humores das personagens, suas roupas, além das cidades que ambientam a trama. Trata portanto da carpintaria da produção.

A categoria Descritiva monta, desse modo, a "ambiência" que envolve a narrativa, define caminhos para a audiência seguir o contato com a obra de acordo com a perspectiva pensada pela produção.

\section{b) Passagem de texto}

Essa categoria representa algo bem próximo dos ensaios realizados pelos atores. São sequências de cenas de leituras dramáticas nas quais Alice Braga e Daniel de Oliveira passam as falas que serão interpretadas a seguir durante o desenvolvimento da narrativa ficcional.

Ou seja, a estrutura na categoria Passagem de Texto funciona da seguinte maneira: é exibida a sequência dos atores lendo suas falas interagindo dramaticamente e, em seguida, é exibida a sequência da trama ficcional com as mesmas falas. O que acontece, portanto, é a formalização da ideia de que aquilo que é interpretado foi construído a partir de um roteiro, uma legitimação da ficcionalidade da obra. Essa categoria antevê o que estará presente na sequência da diegese e oficializa a construção intencional e vinculada a um âmbito produtivo dos diálogos componentes de Latitudes (e, portanto, da obra como uma produção ficcional e produto cultural).

\footnotetext{
${ }^{40} \mathrm{~A}$ análise dos episódios televisionados foi possível devido à gravação no serviço de Video On Demand NOW, oferecido pela operadora de TV paga Net. Anteriormente a essas gravações, tentamos conseguir os episódios a partir de contato com a produtora Los Bragas, que resultou em uma negativa sob a justificativa de os direitos da série televisiva Latitudes pertencerem à TNT.
} 


\section{c) Sugestões dos atores}

Essa categoria é definida pela intervenção ativa dos atores na construção da obra ficcional. Ela se traduz em sugestões que Alice Braga e Daniel de Oliveira fazem nas sequências de ensaios exibidas nos espaços ocupados pelos extras da produção na narrativa televisionada. Entendemos que as colaborações da equipe de produção, nomeadamente dos atores, ocorre em vários momentos da obra. No entanto, para essa categoria, selecionamos as cenas com enunciados de Alice e Daniel; ou seja, os momentos em que as suas vozes compõem a narrativa, após o processo de edição.

Revela o caráter "colaborativo" de Latitudes e como sua realização contém em si uma multiplicidade de vozes que ajudam na construção de personagens complexas que acabam criando perspectivas comportamentais independentes da autoria "oficial". Perspectivas reconhecidas pelos próprios atores que assumem as personagens e sugerem caminhos e reações diferentes das definidas previamente no roteiro.

\section{d) Orientações do diretor}

Essa categoria se define por intervenções do diretor Felipe Braga no decorrer dos ensaios (leituras dramáticas) transmitidos nos episódios televisionados de Latitudes. Nessas orientações, o diretor imprime características às personagens, como o gênio forte de Olívia e o desejo de liberdade de José. A mesma observação feita sobre as intervenções dos atores é válida aqui. Imaginamos que sua participação durante os ensaios preparatórios às gravações de Latitudes tenha sido mais intensa do que a edição revela. No entanto, em caráter de análise de formato do produto audiovisual, consideramos o que chega às audiências pela televisão.

Nesses espaços, o diretor também revela particularidades emocionais e profissionais das personagens, em um processo de construção de suas identidades. Esse acrescimento de detalhes ajuda no entendimento de Olívia e José pelos atores Alice Braga e Daniel de Oliveira, o que auxilia na constituição dramática das personagens, e também baliza a compreensão da audiência, que passa a encarar as informações trazidas pelo diretor da obra como potencialmente legítimas e verdadeiras.

\section{e) Caracterização das personagens}

Menos comum que as outras, essa categoria fica evidente principalmente nos primeiros episódios televisionados de Latitudes. Durante as sequências de 
caracterização, elas são exibidas se maquiando ou provando roupas no estúdio, essas imagens sempre complementares às descrições das personagens. No Primeiro Destino - Paris/ENSAIO, por exemplo, Alice Braga é mostrada aplicando a própria maquiagem em meio a uma conversa na qual a maquiadora da equipe ressalta que é importante que ela mesma se maquie porque Olívia é uma "mulher moderna que passa a própria maquiagem".

\section{f) Erros de gravação}

Única categoria que é exibida no decorrer do desenvolvimento da diegese, e não a partir do recurso voice over ou em uma sequência de planos com extras gravados em estúdio. Mostra os "erros" dos atores enquanto estão mergulhados na narrativa ficcional. É a única parte dos conteúdos extras da produção feitos para os episódios televisionados que não foi pretensamente pensada, mas aconteceu naturalmente durante a realização da obra.

A partir dessas categorias de análise definidas, foi realizada a assistência de todos os episódios televisionados de Latitudes para que as intervenções da produção, que os diferenciam dos episódios disponíveis online, pudessem ser categorizadas. Com base nos resultados obtidos, chegamos à seguinte tabela, que categoriza todos os conteúdos extras de produção.

Tabela 3: Categorias dos conteúdos extra-ficcionais

\begin{tabular}{|c|c|c|c|c|c|c|}
\hline & $\begin{array}{l}\text { Inserções } \\
\text { descritivas }\end{array}$ & $\begin{array}{l}\text { Passagem } \\
\text { de texto }\end{array}$ & $\begin{array}{l}\text { Sugestões } \\
\text { dos atores }\end{array}$ & $\begin{array}{c}\text { Orientações do } \\
\text { diretor }\end{array}$ & $\begin{array}{l}\text { Caracterização de } \\
\text { personagens }\end{array}$ & $\begin{array}{l}\text { Erros de } \\
\text { gravação }\end{array}$ \\
\hline Paris & 10 & 13 & 4 & 13 & 1 & 2 \\
\hline Londres & 5 & 25 & 4 & 8 & - & 1 \\
\hline Veneza & 9 & 18 & 4 & 4 & 4 & 3 \\
\hline José Ignacio & 9 & 16 & 8 & 6 & 2 & 3 \\
\hline São Paulo & 5 & 14 & 3 & 9 & 3 & - \\
\hline Porto & 6 & 19 & 4 & 3 & - & 2 \\
\hline Buenos Aires & 4 & 26 & 5 & 5 & 2 & - \\
\hline Istambul & 10 & 17 & 2 & 10 & 1 & 1 \\
\hline Total & 58 & 148 & 34 & 58 & 13 & 12 \\
\hline
\end{tabular}

O Primeiro Destino - Paris foi o único episódio no qual o número de conteúdos extras com passagens de texto foi igual ao número de inserções com orientações do diretor. Em todos os outros episódios, as passagens de texto são superiores a qualquer outra categoria. O Segundo Destino - Londres e o Quinto Destino - Porto foram marcados pela ausência de conteúdos com caracterização de 
personagens, o que mostra que nem todas as categorias aparecem em todos os episódios da série.

O Terceiro Destino - Veneza se revela bastante equilibrado ao apresentar números iguais de conteúdos com sugestões dos atores, orientações do diretor e caracterizações de personagens. Diferente do Sétimo Destino - Buenos Aires, no qual fica evidente a preponderância de inserções com passagens de texto frente a pouquíssimas de outras categorias - marcado, inclusive, pela ausência de erros de gravação. Os erros de gravação também estão ausentes no Quarto Destino - São Paulo, sendo essa categoria e a "caracterização dos personagens", as únicas que não aparecem em todos os episódios. O Oitavo Destino - Istambul foi o episódio que menos teve sugestões dos atores e, junto com o Primeiro Destino - Paris, o que mais teve inserções descritivas.

Todos esses conteúdos extras são apresentados basicamente de três maneiras identificadas na análise para essa pesquisa: 1) Voice over, quando a voz do diretor Felipe Braga ou dos atores Alice Braga e Daniel de Oliveira aparece por cima da cena ficcional sendo apresentada. É quando a produção interfere diretamente na diegese durante o seu desenvolvimento; 2) Planos-sequência, que são sequências inteiras de cenas dos extras sendo apresentados em estúdio. Nesses momentos, imagem e som são exclusivos dos novos conteúdos extra-ficcionais da produção; 3) Tela dividida, que são momentos em que tanto as imagens da trama ficcional quanto os conteúdos extras gravados em estúdio aparecem em uma tela dividida ao meio.

Essas categorias estruturais também serão levadas em conta para a análise das inserções de conteúdos extras da produção na transposição de Latitudes da internet para a plataforma televisiva. Com base nessa sistematização de formato de inserção dos conteúdos, temos a seguinte tabela:

Tabela 4: Formatos de inserção dos conteúdos extra-ficcionais

\begin{tabular}{|c|c|c|c|}
\hline & Voice over & Sequências & Tela dividida \\
\hline Paris & 7 & 34 & - \\
\hline Londres & 4 & 26 & 7 \\
\hline Veneza & 6 & 25 & 1 \\
\hline José Ignacio & 8 & 23 & 1 \\
\hline São Paulo & 5 & 21 & 1 \\
\hline Porto & 4 & 21 & 1 \\
\hline Buenos Aires & 4 & 27 & 4 \\
\hline Istambul & 5 & 25 & 7 \\
\hline Total & 43 & 202 & 22 \\
\hline
\end{tabular}


Percebe-se que o Primeiro Destino - Paris é o que concentra o maior número de sequências e o único episódio que não apresenta nenhuma inserção com a tela dividida entre o conteúdo ficcional e os extras da produção. Diferente do Segundo Destino - Londres e do Oitavo Destino - Istambul, que apresentam os maiores números de inserções com telas divididas - com sete cada.

O recurso de divisão de telas foi muito pouco utilizado no Terceiro Destino - Veneza, no Quarto Destino - José Ignacio, no Quinto Destino - São Paulo e no Sexto Destino - Porto, com apenas uma inserção em cada um deles. O Sétimo Destino - Buenos Aires e o Quinto Destino - São Paulo marcaram o mesmo número de voice overs (cinco em cada), formato de inserção que se manteve mais estável entre todos os episódios televisionados de Latitudes.

Após a análise individual, é possível chegar a um gráfico geral das inserções de conteúdos extra-ficcionais na transição de Latitudes entre a internet e a televisão. No total, foram 58 inserções de conteúdos descritivos; 148 com passagens de texto; 34 com sugestões dos atores; 58 com orientações do diretor; 13 com caracterizações das personagens e 12 com erros de gravação.

Todos os extras da produção que aparecem nos episódios exibidos pela TNT podem ser categorizados e quantificados de acordo com o seguinte gráfico:

Gráfico 4: Conteúdos extra-ficcionais de Latitudes

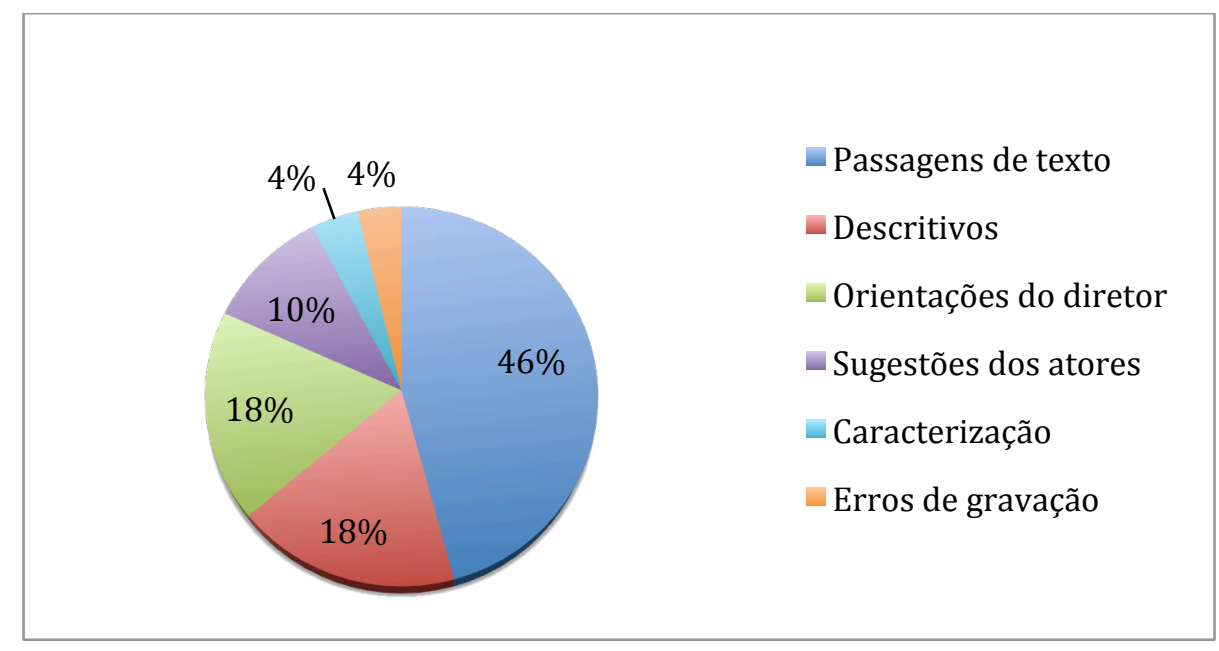

Temos também a quantidade total de formatos desses conteúdos novos inseridos, que se traduz por: 23 voice overs; 202 sequências de cenas gravadas em 
estúdio e 22 telas divididas entre conteúdos ficcionais e ensaios. Esses números estão representados pelo seguinte gráfico:

Gráfico 5: Formatos de inserção dos conteúdos extra-ficcionais

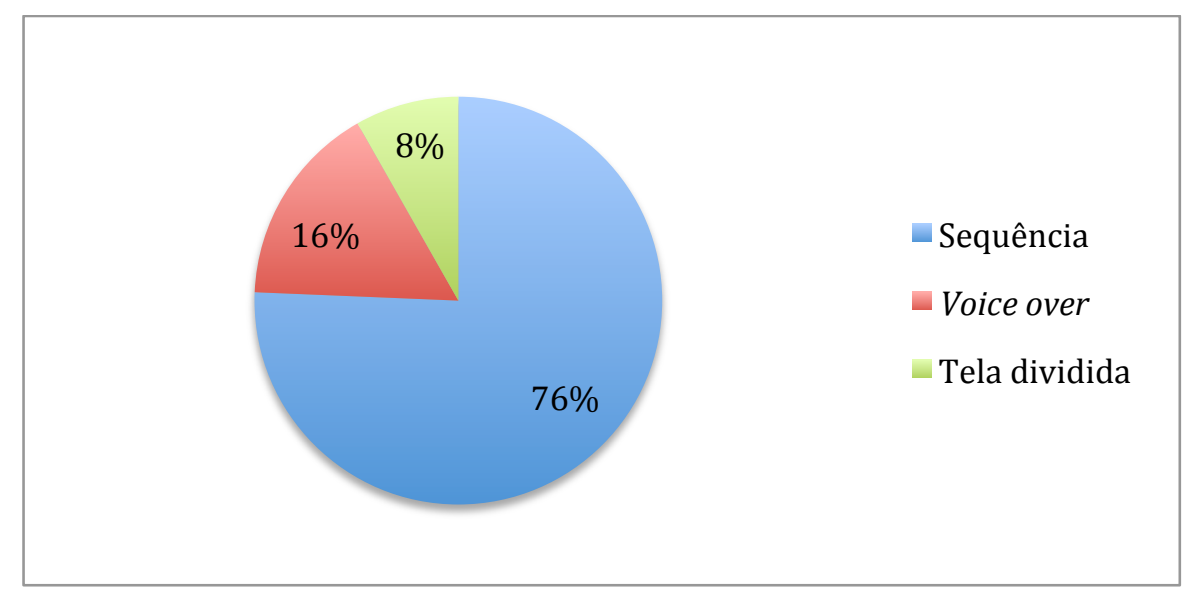

A partir da sistematização desses dados, é possível chegar a algumas conclusões sobre a transposição da ficção Latitudes do YouTube para a televisão. Fica claro que o produto audiovisual passou por transformações no trânsito entre as plataformas, utilizando uma estratégia de inserção de conteúdos extra-ficcionais que exibem detalhes da produção da obra.

Dentre esses conteúdos, a categoria mais explorada foi a passagem de textos (46\% das inserções), com os atores lendo dramaticamente, em estúdio, o roteiro, cujas cenas ficcionais referentes eram exibidas a seguir. Logo depois, aparece a estratégia de inserir conteúdos descritivos (18\% dos casos) - que ambientam a narrativa, dando informações sobre as cidades e hotéis nos quais a trama se desenvolve - empatada com as orientações do diretor Felipe Braga (18\%), que surgem para trazer mais dramaticidade às personagens.

Alice Braga e Daniel de Oliveira também aparecem como vozes ativas na etapa produtiva de Latitudes, apresentando as sugestões dos atores em $10 \%$ das inserções de conteúdos extra-ficcionais. Em menor quantidade, vêm as caracterizações das personagens e os erros de gravação (4\% de inserções cada), recurso menos utilizados e os únicos que não estão presentes em todos os episódios da obra.

Desse modo, é perceptível que os extras cumprem duas funções principais em Latitudes: 1) por meio da utilização intensa do recurso de passagem de texto, a 
produção teve como objetivo destacar exatamente o texto da obra, o que foi considerado pela crítica especializada um ponto alto de Latitudes; 2) exibir conteúdos descritivos que servem para dar referências sobre os ambientes nos quais a narrativa se desenvolve. Nesse ponto, é importante lembrar que Latitudes se passa em oito países diferentes, sempre com alusões a itens de consumo cultural e de luxo. Se a narrativa diegética não dá conta de apresentar esse signos às audiências, os extras de produção se encarregam disso.

Quanto ao formato de inserção desses conteúdos extra-ficcionais, percebemos a preponderância (identificados em 76\% dos casos) de planossequência com várias cenas gravadas em estúdio que apresentavam Felipe Braga, Alice Braga e Daniel de Oliveira no processo de construção de Latitudes, escancarando a ficcionalidade da obra. Em seguida, com 16\%, vêm as inserções em voice over, cuja construção acopla as imagens da diegese com narrações dos bastidores da produção. Por fim, são apresentadas intervenções com tela dividida em $8 \%$ dos casos, nas quais os conteúdos ficcionais são exibidos ao lado dos conteúdos extras.

Desse modo, não é apenas a temporalidade de Latitudes que se modifica na transposição da narrativa da internet para a televisão. A partir da inserção de conteúdos extras, há certos deslocamentos da produção de sentido, uma vez que os espectadores são levados a revisitar a obra com novas informações sobre seu contexto de produção. Entender de que maneira isso ocorre é fundamental para o debate sobre a construção de gêneros e formatos de ficção audiovisual hipermídiatica e no contexto das redes sociais.

(...) compreensão de que atualmente estudar as narrativas de televisão significa estar atendo a formatos de ficção regidos não apenas pelo princípio da adaptação ou da tradução intersemiótica (JAKOBSON, 2003), mas, sobretudo, pelo princípio da convergência. (MUNGIOLI, 2012, p. 106)

É importante ter em vista o caráter conflituoso apontado por Mungioli (2006) entre as esferas de criação e da produção da indústria cultural. Ao mesmo tempo em que as realizações ficcionais precisam obedecer à lógica de mercado de produção em série, rápida, também têm como objetivo final a originalidade. Essa tensão entre criação-padronização (Morin, 2005) é revelada em Latitudes, de maneira que o "fazer" da obra ficcional passa constituir a própria narrativa. 
A partir do trabalho coletivo parcelado (Mungioli, 2006) mostrado nos extras de produção, é possível verificar que a realização de Latitudes não é monofônica, mas constituída por diversas vozes que fazem participações ativas na construção das personagens e da narrativa. Esse capítulo tem, até o momento, dado conta de identificar e categorizar os formatos pelos quais essa dinâmica ocorre, em caráter exploratório.

A conclusão que se tira dessa sistematização é que a obra lança mão de algumas estratégias para realizar a transposição entre plataformas e, com isso, estabelece rupturas em sua ficcionalidade. A patir do diálogo entre o "real" e o "ficcional”, são dadas novas possibilidades de produção de sentido às audiências. Os enunciados na televisão se constituem, portanto, como um eu-origem-real (Jost, 1997), apoiados nas figuras do diretor e dos atores. São, desse modo, dois aspectos importantes: um relacionado à cocriação e outro à quebra da ficcionalidade da narrativa.

Se, por um lado, esses procedimentos imprimem à linguagem televisual a marca da interação e da cocriação, por outro, introduzem no mundo da ficção uma ancoragem na realidade e no cotidiano muito mais próxima da imitação ("como se") que da representação ("como"), uma vez que de certa maneira o euorigem-fictício (HAMBURGER, 1986) sofre uma inflexão em direção do autor daquela proposta de encaminhamento de ação ou da trama. (MUNGIOLI, 2012, p. 112)

Ao inserir os extras na televisão, Latitudes orienta o leitor a passar de um nível interpretativo a outro. Falamos aqui sobre o leitor-modelo (Eco, 1994), capaz de colaborar com o desenvolvimento da narrativa independentemente do desejo autoral.

Compreender uma narrativa não é somente seguir o esvaziamento da história, é também reconhecer nela "estágios", projetar os encadeamentos, horizontais do "fio" narrativo sobre um eixo implicitamente vertical; ler (escutar) uma narrativa não é somente passar de uma palavra a outra, é também passar de um nível a outro. (BARTHES, 2009, p. 27)

Ainda de acordo com Barthes (2009), a transposição do leitor de um nível interpretativo a outro depende, dentre outros fatores, das "orientações" dadas pelas unidades narrativas. Elas podem assumir caráter indicial ou de informante: enquanto os indiciais têm significados implícitos, "remetendo a um caráter, a um sentimento, a uma atmosfera" (BARTHES, 2009, p. 35), os informantes são mais objetivos e dão características prontas acerca da narrativa. 
Os índices têm pois sempre significados implícitos; os informantes, ao contrário, não o têm, pelo menos no nível da história: são dados puros imediatamente significantes. Os índices implicam uma atividade de deciframento: trata-se para o leitor de aprender a conhecer um caráter, uma atmosfera; os informantes trazem um conhecimento todo feito; sua funcionalidade, como a das catálises, é pois fraca, mas não é nula: qualquer que seja sua "palidez" em relação ao resto da história, o informante (por exemplo a idade precisa de uma personagem) serve para dar autenticidade à realidade do referente, para enraizar a ficção no real: é um operador realista e, neste título, possui uma funcionalidade incontestável, não no nível da história, mas no nível do discurso. (BARTHES, 2009, ps. 35-36)

Dadas as categorias, é possível classificar os conteúdos extras como indiciais ou informativos, de acordo com sua classificação. As inserções descritivas, ao ambientarem a obra, assumem papel de índices. O mesmo ocorre com as sugestões dos atores, que posicionam suas impressões sobre a narrativa. Por outro lado, as orientações do diretor, mais objetivas acerca da trama, o colocam na posição de informante, com dados concretos sobre a construção da história. Também funcionam dessa maneira as categorias passagem de texto $\mathrm{e}$ caracterização das personagens, que trazem âncoras sólidas no estabelecimento da trama, balizando sua produção de sentido.

Desse modo, fica ainda mais evidente o caráter funcional que os extras da televisão assumem. Não são conteúdos dispensáveis, mas constituintes da obra em um formato diferente do disponibilizado no YouTube. Nesse formato, o mundo ficcional e o mundo "real" são apresentados por alternância, que consiste em "contar as duas histórias simultaneamente, interrompendo ora uma ora outra, para retomá-la na interrupção seguinte" (TODOROV, 2009, p. 244). É o que ocorre com a maior parte dos conteúdos extras de Latitudes, inseridos em planos-sequência suspendendo temporariamente o desenvolvimento da diegese.

São estratégias que possivelmente buscam adequar a obra originalmente lançada na internet ao formato de série televisiva. Como tal, ela precisa de temporalidades e conteúdos específicos que a encaixem na grade televisiva. Essa etapa do trabalho se constitui como um esforço para verificação e análises estruturais que diferenciam a narrativa online da televisionada. A partir desses avanços, será possível dialogar com outras produções que realizaram o trânsito internet-TV e constituem modelos de produção, distribuição e consumo próprios 
dos tempos de convergência, e, portanto, reflexo de uma sociedade integrada em redes e com conteúdos cada vez mais diluídos em múltiplas plataformas.

\subsection{Gênero ficcional e documentário: uma aproximação}

Todas as transformações identificadas na transposição da narrativa entre a internet e a televisão são importantes para análises a respeito dos formatos assumidos por Latitudes em cada uma das plataformas. A partir das categorizações desenvolvidas anteriormente, foi possível identificar duas características relevantes nos conteúdos extras televisionados: 1) sua posição fora do universo ficcional de Latitudes; e 2) seu caráter primordialmente informativo sobre a diegese.

Que nosso objeto empírico circula pelas mídias formatado ora como websérie, ora como série televisionada e ora como longa metragem, já foi amplamente descrito. Nesse momento, no entanto, é necessário chamar atenção para algumas redefinições de gênero identificadas com tipologia elaborada para classificar os elementos extra-diegéticos da obra. A pesquisa desenvolvida nessa etapa do trabalho aponta para uma aproximação, na versão de Latitudes exibida pela TNT, entre o gênero ficcional e o documental.

Considerando que inseridos no espectro do gênero documental estão todos os registros e mediações da realidade (Sacrini, 2004), é interessante perceber que a produção de Latitudes usou como recurso a inserção de enunciados fora da diegese, relacionados aos ensaios e etapas de produção da obra e, portanto, ligados ao "real" (ou "não-ficcional"), para compor a narrativa na televisão. Durante essas etapas, registradas e exibidas na montagem da série, é feita uma narrativa documental sobre os processos de realização. Desse modo, a obra mescla o gênero ficcional, que assume centralidade na narrativa, ao gênero documental, que aparece em vários enunciados que servem como "apoio" na transição de Latitudes para a TV, dando origem a um gênero híbrido que dialoga ora com a diegese, ora com o que é alheio a ela, em caráter iminentemente informativo acerca da própria narrativa. 


\section{CAPÍTULO 7: AS ESTRATÉGIAS DE TRANSMIDIAÇÃO EM LATITUDES}

Neste capítulo, entramos a fundo nas análises das estratégias de transmidiação desenvolvidas no âmbito da produção de Latitudes. Durante as etapas anteriores, percebemos que a transmidiação se configura como uma tendência na produção ficcional brasileira, gerando inclusive modelos próprios de negócios e capitalização de conteúdos nas redes sociais.

A quantidade crescente de produções transmídia cria um amplo universo de formatos disponíveis, que utilizam recursos específicos para circular entre as plataformas. Para dar início à identificação das estratégias utilizadas em Latitudes, recorremos a Fechine (2013), que cria categorias para circunscrever conteúdos disponibilizados em múltiplas plataformas. Essa primeira etapa nos permitirá averiguar se os conteúdos transmídia expandem o universo ficcional da obra ou se limitam à propagação da narrativa, como será descrito a seguir.

A escolha dessa abordagem teórica e metodológica se deve à sua aproximação com o objeto, uma vez que o quadro desenvolvido por Fechine (2013) é resultado de uma pesquisa da rede OBITEL Brasil, que se dedica aos estudos sobre a ficção seriada nacional. Apesar de ter sido formatado para análises de telenovelas, a autora propõe e incentiva a aplicação das categorias em outros formatos, a fim de validá-las.

\subsection{As estratégias de Propagação e de Expansão}

Antes de iniciarmos as análises, é importante fazer uma breve explicação conceitual das categorias para que sejam definidas as operações de transmidiação estabelecidas em Latitudes. A princípio, Fechine nos dá duas estratégias: Propagação e Expansão. Por Propagação, se entende a recuperação e repercussão dos conteúdos ficcionais em várias plataformas, em um circuito retroativo de interesse. A Expansão, por outro lado, se refere ao aumento dos universos narrativos para além da plataforma principal. Cria histórias interdependentes, mas dotadas de sentido se consideradas isoladamente (Fechine, 2013).

Quanto aos conteúdos transmídia na esfera da Propagação, podem ser classificados como 1) Reformatados (adaptam para outras plataformas conteúdos que já foram ofertados na plataforma principal. Não oferecem novas informações, mas variações do conteúdo original) e 2) Informativos (por meio de outras 
plataformas, oferecem informações associadas ao texto de referência que não interferem diretamente na diegese. Ou seja, não são ficcionais, mas ajudam a compreender a ficção). Na esfera da Expansão, há outras duas categorias possíveis para os conteúdos: 1) de Extensão textual (responsáveis por desdobramentos diegéticos, estendem o texto de referência a partir de seus núcleos, como caracterização de personagens, lugares e ambientes) e 2) de Extensão lúdica (referem-se a jogos para interação com os usuários, em busca de conexões entre a unidade narrativa e o aspecto lúdico).

Dentro da estratégia de Propagação, os Conteúdos reformatados se dividem em três categorias: 1) Antecipação (despertam interesse nos consumidores sobre a narrativa principal, adiantando em outras mídias o que será exibido); 2) Recuperação (possibilitam que os consumidores revejam cenas, por meio da reexibição da programação original em outras plataformas) e 3) Remixagem (são resultado da apropriação do conteúdo original em outro contexto - reeditado, com imagens manipuladas -, que permite a ressignificação de sequências já exibidas).

Entre os Conteúdos informativos, existem mais duas divisões: 1) Contextuais (oferecem informações "reais" sobre o contexto da diegese, como fatos históricos que ajudam no entendimento da trama) e 2) Promocionais (proporciona conhecimento sobre o fazer-se da narrativa, com informações sobre os profissionais envolvidos e a realização da obra, estabelecendo uma metanarrativa).

Na esfera da Expansão, entre os Conteúdos de extensão textual, existem as: 1) Extensões narrativas (novas narrativas, desenvolvidas em outros meios, a partir de recuos ou avanços da narrativa principal) e 2) Extensões diegéticas (oferecem novos conteúdos narrativos ligados diretamente à diegese - são diferenciadas das extensões narrativas por não interferirem no encadeamento das ações na trama principal. Tratam-se, portanto, de diários, álbuns de fotografias e outros documentos e artefatos apresentados ao público, que aumentam a impressão de realidade sobre a narrativa).

Por fim, aparecem as categorias dos Conteúdos de extensão lúdica, a saber: 1) Extensões vivenciais (exigem o envolvimento ativo do consumidor em atividades propostas pelos produtores, como games, quizzes e concursos - relacionados à narrativa central e disponíveis em outras plataformas) e 2) Extensões de marca (promove a narrativa do mundo simbólico para o material, trazendo o consumidor para "dentro" da diegese, por meio de conteúdos promocionais, como protetores de 
tela, roupas e toques para celular).

Segue, portanto, quadro desenvolvido por Fechine (2013), a partir do qual damos prosseguimento às considerações:

Tabela 5: Estratégias e conteúdos transmídia

\begin{tabular}{|c|c|c|}
\hline Estratégias & Conteúdos & \\
\hline \multirow{5}{*}{ Propagação } & \multirow{3}{*}{ Conteúdos reformatados } & Antecipação \\
\hline & & Recuperação \\
\hline & & Remixagem \\
\hline & \multirow[b]{2}{*}{ Conteúdos informativos } & Contextuais \\
\hline & & Promocionais \\
\hline \multirow{4}{*}{ Expansão } & \multirow[t]{2}{*}{ Conteúdos de extensão textual } & Extensões narrativas \\
\hline & & Extensões digéticas \\
\hline & \multirow[t]{2}{*}{ Conteúdos de extensão lúdica } & Extensões vivenciais \\
\hline & & Extensões de marca \\
\hline
\end{tabular}

Fonte: FECHINE, 2013, p. 37.

Por meio das estratégias de produção elucidadas até esse ponto do trabalho, portanto, é possível categorizar Latitudes como uma obra que desenvolve a Estratégia Transmídia de Propagação, com um conteúdo repercutindo ou reverberando o outro, convidando os consumidores a retomarem a trama em várias plataformas. Isso ocorre devido à ausência de elementos diegéticos entre os conteúdos extras veiculados na narrativa televisionada. Apesar de ela expandir o repertório da audiência em termos de produção de sentido, devido à ruptura com a ficcionalidade e disponibilização de novos elementos para fruição, eles têm caráter informativo ou indicial acerca da trama, e não a expandem diegeticamente.

Dito de outra forma, o universo ficcional (Jenkins, 2008) não se expande por meio dos conteúdos extra-diegéticos. Apesar de dialogarem com a trama e trazerem novos sentidos, eles não a alteram ou complementam objetivamente dentro dos limites ficcionais. Quanto às ações transmídia, elas flutuam de acordo com a plataforma considerada. A seguir, serão consideradas duas operações de transmidiação diferentes, ambas categorizadas a partir do que se estabeleceu como a nave-mãe da ficção Latitudes: a websérie disponibilizada no YouTube. 


\section{a) Do YouTube para a televisão}

Na televisão, observa-se a predominância de Conteúdos informativos, por conta da inserção de informações "de fora da trama" que ajudam a compreendê-la e caracterizá-la enquanto diegese.

[Os Conteúdos informativos] exploram aspectos pertinentes à narrativa sem interferirem, no entanto, na "realidade" interna à trama (sem implicação ou participação nas ações). Colaboram para construção de conhecimento "enciclopédico" em torno da diegese e/ou do processo de produção do programa. (FECHINE, 2013, p. 41)

É precisamente o que acontece quando a produção original do YouTube é veiculada na TV. A trama permanece precisamente a mesma, mas os episódios ganham comentários do diretor e dos atores, além de explicações sobre ângulos de câmera, iluminação e sentimentos das personagens, que são intercalados com o desenvolvimento da ficção. Esses "extras" evidenciam, portanto, a encenação, aumentando o grau de compreensão da etapa produtiva que está "fora" do universo ficcional.

Entre os Conteúdos informativos na relação de transmidiação YouTube Televisão, predominam os Promocionais. "São informações de caráter marcadamente extratextual sobre os profissionais envolvidos e os processos de realização" (FECHINE, 2013, p. 43). É interessante notar que essa classificação dialoga com o caráter de informantes (Barthes, 2009) que são legados ao diretor e aos atores quando assumem seu papel nos conteúdos extra-diegéticos, conforme discutimos no capítulo anterior.

É precisamente por meio dessas ações que os produtores buscam redefinir os olhares da audiência para que retornem à ficção com novas informações a respeito dos caminhos que levaram à construção e desenvolvimento da trama. Apesar de esse percurso não garantir expansão à diegese, ele e importante por delimitar uma expansão do conhecimento enciclopédico acerca da obra, revelando principalmente aspectos sobre os seus processos e suas etapas de realização. As novas perspectivas de produção de sentido a partir dos contatos com os conteúdos televisionados são potencializadas na fruição repetida da obra, conforme discutiremos a seguir. Desse modo, é possível destacar as estratégias e conteúdos transmídia da ficção Latitudes em sua flutuação da internet para a televisão da seguinte maneira, a partir do quadro proposto por Fechine: Estratégia de 
Propagação, com conteúdos Informativos promocionais.

\section{b) Do YouTube para o cinema}

No cinema, verifica-se a predominância de Conteúdos reformatados, que não oferecem novas informações, mas variações da narrativa principal (FECHINE, 2013). É precisamente o que ocorre no longa metragem, formato cuja principal mudança é a montagem do produto final. Basicamente, os episódios da websérie Latitudes, ao virarem o filme Latitudes, tiveram: 1) algumas cenas cortadas e outras reordenadas (a maneira como o casal José e Olívia se conhece, por exemplo, que é esclarecida no $1^{\circ}$ Destino - Paris, é a última cena do filme); 2) trilha sonora ligeiramente modificada para tirar a idéia de fim de cada episódio e 3) algumas imagens inéditas, inseridas para cobrir os diálogos das personagens.

Entre os Conteúdos reformatados predominantes na relação de transmidiação YouTube - Cinema, destaca-se a Recuperação. Os conteúdos de recuperação permitem ao público ter acesso à mesma trama estabelecida a partir da narrativa central, mas reformatada para a realidade da sua plataforma. É precisamente o caso do filme Latitudes; ele é quase uma montagem dos webisódios disponibilizados pelo YouTube, com pequenas diferenças de edição, que o adaptam à linguagem cinematográfica. É possível destacar as estratégias e conteúdos transmídia da ficção Latitudes em sua flutuação da internet para o cinema da seguinte maneira, a partir do quadro proposto por Fechine: Estratégia de Propagação, com Conteúdos reformatados de recuperação.

Uma grande discussão levantada a partir dos resultados dessa pesquisa até esse ponto se refere à localização da nave-mãe em uma plataforma online (YouTube). Normalmente, em relações de transmidiação que envolvem internet e televisão ou internet e cinema, a narrativa central se concentra nos filmes ou nas produções de ficção televisiva, de modo que a internet atua como satélite para concentrar conteúdos que complementam as histórias contidas em outras mídias. Tanto é verdade que as próprias categorias desenvolvidas por Fechine e utilizadas nessa etapa trabalho consideravam originalmente as telenovelas, sempre, como o eixo central a partir do qual a narrativa se espalha (para a internet).

A própria pesquisadora, entretanto, abre a possibilidade para novas dinâmicas de aplicação dessas categorias, dando "permissão" para a análise feita nesse trabalho. Em Latitudes, observa-se um reconhecimento do potencial do 
YouTube para abrigar o eixo central da ficção e espalhar a narrativa e conteúdos relacionados a ela nas demais plataformas. É um novo modelo de produção e de negócio audiovisual ficcional que merece nota e aprofundamento reflexivo.

Esse potencial dinâmico das categorias tem mais um desdobramento interessante: possibilita que os processos de transmidiação em uma única obra sejam pluralizados e classificados individualmente. Quando se fala em transmidiação de ficções em mais de duas plataformas, é preciso analisar detalhada e particularmente cada uma das relações estabelecidas. A estratégia metodológica adotada para essa pesquisa foi analisar as relações sempre a partir do que foi estabelecido como nave-mãe da narrativa, uma decisão tomada durante o desenvolvimento do trabalho, quando colocar em prática as categorizações revelou a complexidade das estratégias e dos conteúdos de transmidiação. Foi preciso classificar distintamente as relações estabelecidas a partir da transmidiação entre YouTube e televisão e entre YouTube e cinema, ao invés de reduzir tudo à transmidiação na obra Latitudes. Essa mesma produção, inclusive, estabelece novas estratégias e tipos de conteúdos transmidiáticos em trailers, redes sociais e sites, que não foram contemplados nesse momento, mas representam um rico campo de estudos para o futuro.

\subsection{Reassistibilide e Cenas Deletadas}

Cabe destacar que a configuração estética e discursiva de Latitudes (concentrar a nave-mãe (Jenkins, 2008) na internet), denota uma situação incomum no universo comunicacional brasileiro. Pois mostra uma inversão em relação ao lugar da televisão, tradicionalmente vista como a mídia mais importante em termos de audiência, que passa a ter um desempenho secundário em relação ao conteúdo disponibilizado na internet. É a websérie que concentra a narrativa diegética em sua totalidade e conta com a televisão para mostrar os extras da produção. Sem dúvida, é uma mudança que merece nota, para se entender de que maneira o YouTube vem se inserindo na cultura da convergência e na lógica do entretenimento audiovisual.

(...) nos interrogamos se o YouTube introduziu algo de novo no contexto de uma história maior, que é a das mídias e linguagens audiovisuais. Então nos perguntaremos: que novidades foram trazidas por essa história e esse contrato de fundação para a história da cultura e midiatização audiovisual, que é o contexto em que, a partir de nossa perspectiva, devemos analisá-lo? Isto é, em que medida o YouTube nasceu e se constituiu como um 
projeto separado do cinema e da televisão ou constitui, por outro lado, uma continuidade destes dois grandes meios de comunicação que o antecederam? Estas são perguntas que nos forçam a rever a situação atual como uma mídia e, por isso mesmo, a discutir a tese de Amanda Lotz (2007), que sustenta que no YouTube há, na post-network era, que é a mesma que estamos vivendo agora, a partir das produções dos usuários, manifestações de uma nova fase na história da televisão. (CARLÓN, 2013, p. 109)

Com base nas discussões efetuadas nos capítulos anteriores acerca do trânsito da narrativa de Latitudes entre todas as plataformas que a veicularam e com a nave-mãe concentrada no YouTube, percebemos que a obra é constantemente "revisitada" nas outras plataformas. A televisão, por meio dos novos conteúdos com os extras de produção, dá conta de exibir a narrativa diegética (anteriormente disponibilizada integralmente online) com novas perspectivas de interpretação, uma vez que explica sentimentos, emoções e particularidades das personagens e ambientes sob a perspectiva da equipe de produção.

Desse modo, após as estratégias de propagação identificadas na obra, agora nos deparamos também com a inclusão de cenas deletadas (Jenkins, 2012) na plataforma televisiva. Jenkins (2012) diferencia as cenas deletadas das cenas faltantes (missing scenes). De acordo com o autor, enquanto as cenas faltantes se referem a partes da história deixadas com lacunas ${ }^{41}$ sem essa intenção por parte dos realizadores da obra, as cenas deletadas referem-se às partes que os produtores retiraram intencionalmente da narrativa.

Ao observar a inclusão de novos conteúdos na televisão (que não estão disponíveis na websérie), percebe-se que se trata da inserção de cenas deletadas da narrativa para o YouTube, em uma estratégia da produção para levar o público à busca por novos conteúdos na plataforma televisiva, diegéticos ou não.

Ambos (cenas deletadas e cenas faltantes) podem representar contribuições criativas para a nossa compreensão do trabalho, mas eles têm status diferente, pois nossa cultura tende a valorizar o autor original sobre seus leitores. (JENKINS, 2012, p. 16)

\footnotetext{
${ }^{41}$ Vemos nesse tipo de classificação semelhanças com a categorização feita por Barthes (1992) acerca das características dos textos literários, definindo dois tipos de texto: o legível e o escrevível. O texto escrevível possui um modelo produtor que convida o leitor a deixar sua posição tranquila de consumidor e se aventurar como produtor de textos. Essa modalidade pode ser considerada uma característica das narrativas transmidiáticas. Já o texto legível não permitiria ao leitor desenvolver narrativas, pois não conteria lacunas em sua composição.
} 
O cinema, por sua, vez, basicamente repete a história contada no YouTube, mas sem a serialidade marcada nos webisódios. Em momento nenhum, há expansão do universo ficcional ou a inserção de novas tramas ou revelações na narrativa em uma plataforma particular. Fica claro, portanto, que a mesma história é contada paralelamente em três mídias diferentes, o que evidencia a reassistibilidade como recurso narrativo no desenvolvimento de Latitudes.

Observa-se, desse modo, nessa estratégia de disponibilização/exibição, a lógica que se assenta sobre o fundamento da reassistibilidade ${ }^{42}$ de fruição do conteúdo ficcional, conforme destaca Massarolo:

Entender não somente o que é narrado, mas a forma como a história é contada, caracteriza a estética da repetição como a experiência de reassistir episódios ou partes deles pelos mais diversos motivos, desde análises dos momentos mais significativos, passando pelas questões emocionais. (MASSAROLO, 2013, p. 339)

Os episódios televisionados, exibidos após a disponibilização no canal do YouTube, contêm o mesmo desenvolvimento diegético da trama online, porém revelam aspectos dos extras da produção. A antecedência de disponibilização do conteúdo no YouTube fez parte de uma estratégia da produção para cativar os espectadores a assistir às versões fílmica e televisual da trama. Dessa forma, por ter sido veiculado inicialmente na internet, Latitudes seria uma produção que já chegaria aos cinemas com um público formado, como já foi destacado anteriormente.

Percebe-se, portanto, o estímulo à migração da audiência entre as diferentes plataformas, com a intenção de fornecer ao espectador experiências narrativas e de interpretação exclusivas de cada uma delas. Trata-se novamente da reassistibilidade (Mittel, 2011), conceito chave para o entendimento das estratégias narrativas em Latitudes, que será tratado adiante. De acordo com Pelegrini,

A reassistibilidade não deve ser confundida com a reprise, prática antiga na indústria televisual. A reprise usa conteúdo já exibido para compor o fluxo ininterrupto da TV. Trata-se de uma ação do emissor. Em geral, o que se tem à disposição são textos televisuais já vistos e que não podem oferecer nada além do mesmo já visto. Na reassistibilidade, o foco muda para o ato de ler o texto. Para o receptor, há razão em ver novamente algo a que ele já assistiu. Assistir novamente não é o mesmo que ter a

\footnotetext{
${ }^{42}$ Essa discussão está parcialmente contida no texto O Universo Narrativo de Latitudes: a reassistibilidade como estratégia de transmidiação (Mungioli; Penner, 2014).
} 
mesma experiência de novo; mas assistir novamente significa ter uma nova experiência (PELEGRINI, 2012, s.p.)

Não é possível considerarmos, portanto, que a posição ativa da produção de circular os mesmos conteúdos por diversas plataformas ocorra para que o público simplesmente veja novamente uma história com a qual ele já teve contato anteriormente. Acreditamos que se trata de uma estratégia de trânsito entre as mídias que propicie às audiências novas experiências na fruição da trama, além de novas perspectivas interpretativas e possibilidade de entendimento integral da complexidade narrativa presente na obra, conforme será explicado a seguir.

\subsubsection{Reassistindo Latitudes}

A estrutura de exibição estabelecida pelos produtores de Latitudes gera um fenômeno digno de discussão, a rewatchability (Mittel, 2011), traduzido por Pelegrini (2012) como reassistibilidade. A reassistência da obra Latitudes é uma das principais estratégias adotadas pela produção, devido à própria estrutura da narrativa (uma história contada em três plataformas, conforme foi descrito anteriormente). Cada episódio de Latitudes se passa em um lugar diferente do mundo, com intertextualidades (Fiske, 1987) que trazem referências das cidades que ambientam a história em determinado momento. São bares, restaurantes, eventos de moda e, principalmente, hotéis (e quartos de hotéis) componentes do imaginário de luxo jetsetter que, aliados à trama baseada quase integralmente nos diálogos entre as duas personagens principais, criam a necessidade de assistir a obra mais de uma vez para que ela seja compreendida em sua totalidade.

Em Veneza, por exemplo, o casal José e Olívia se hospeda no lendário Hotel Danieli, na Doge Dandolo Royal Suite. Grande parte do Terceiro Destino Veneza é dedicada à apresentação da suíte, com referências ao seu primeiro dono e a obras de arte da Itália do século XIV. A audiência é imersa em um mundo de referências culturais extensas demais para que sejam apreendidas no primeiro contato com a ficção. Essa imersão é importante justamente por caracterizar a densidade cultural das personagens, que mostram como são complexas à medida que desenvolvem os diálogos que empurram a trama adiante.

Em dois episódios de Latitudes (Quinto Destino - São Paulo e Sétimo Destino - Buenos Aires), José e Olívia, respectivamente, confrontam os 
relacionamentos que mantém em casa e as consequências do romance que construíram em suas viagens. Mais uma vez, compreender a mudança drástica dos episódios, antes constituídos apenas pelo casal central, e, em seguida, retornar à trama, demanda que a narrativa seja visitada mais de uma vez.

\begin{abstract}
Nesse contexto, emerge, nos últimos anos, uma prática de consumo de mídia que vem responder às demandas de texto com tal sofisticação: a rewatchability (que propomos traduzir como reassistibilidade). Mittel indica que a reassistibilidade é um conjunto de práticas ligada à condição tecnológica de distribuição de conteúdo. Por um lado, a emergência de canais a cabo dedicados a reprises e a situação de reprise de temporadas inteiras em episódios diários ofereceu nova oportunidade de assistir ao material; somemos a isso, ainda, a penetração e os usos dados ao videocassete. Além disso, recentemente, a comercialização de seriados inteiros em DVD tem alterado consideravelmente a situação de recepção de tais produções. Além de tais possibilidades, a gradual conversão do flow televisual em files das redes digitais e seu acesso em quaisquer condições de tempo e espaço para o consumo em computadores e gadgets reforça sobremaneira a alteração nas formas de ver TV. (PELEGRINI, 2012, s.p.)
\end{abstract}

A estrutura de distribuição adotada por Latitudes permite a adesão do modelo de reassistibilidade proposto, exatamente pela complexidade citada anteriormente. A leitura estabelecida a partir do contexto de reassistibilidade permite a busca por elementos que não haviam sido percebidos, o que torna cada contato com a narrativa uma experiência distinta.

Isso fica ainda mais evidente em Latitudes quando se passeia pelas três plataformas que compõem a narrativa, uma vez que a obra disponibiliza formatos diferenciados adequados a cada uma delas. Mittel (2011) define o assistir analítico como uma fruição não apenas dos elementos diegéticos, mas "o virtuosismo de roteiristas e de toda a equipe de produção de compor tramas que se entrecruzam, ironias dramáticas que emergem dos eventos e outros recursos narrativos propostos como efeitos especiais narrativos" (Mittel, 2006, p. 35). É precisamente a definição do que se vê no formato seriado de Latitudes veiculado pela televisão, cujo conteúdo contempla o processo produtivo, o fazer-se da obra, que se torna acessível intercaladamente à narrativa ficcional nos episódios televisionados.

The narrative paratexts that have emerged on DVDs, such as director commentaries and making of documentaries, formalize the analytic rewatch, as you are literally guided through the text by an expert companion. I have argued elsewhere that such hermeneutic impulses are explicitly encouraged by many 
contemporary television serials, as they foreground the operational aesthetic of marveling at a show's complex storytelling mechanics alongside the forward drive of the plot. (MITTEL, 2011, s.p.)

Além dessa possibilidade analítica da produção, a reassistibilidade assegura certo capital simbólico a quem a pratica a partir de determinada obra (Mittel, 2011). Enquanto a primeira assistência é causadora de emoções como curiosidade, surpresa e suspense, reassistir a uma obra garante a experiência de antecipação pelo que está por vir, o que proporciona uma visão diferenciada às demais.

\footnotetext{
"spoiler fans" of Lost - viewers who actively seek out and consume narrative information ahead of time so that they watch new episodes knowing what will happen in advance. Through an online survey, we explored why people would choose to view this way - one of our conclusions was that for many fans, spoilers serve as a way to turn the first-time viewing experience into a practice more akin to rewatching. (MITTEL, 2011, sp)
}

Os fãs, ao reassistirem a obra, tornam-se, portanto, especialistas, o que lhes garante status e legitimidade entre suas comunidades. É jogando com essa possibilidade que o universo narrativo de Latitudes não se altera entre as plataformas pelas quais circula (YouTube, televisão e cinema) - na verdade, a audiência é levada a reassistir a mesma história para compreendê-la plenamente. Não é possível explicar de outra maneira, além das estratégias mercadológicas tratadas anteriormente, a intenção de levar às salas de cinema e aos horários fixos da televisão as audiências que têm acesso à mesma narrativa pela internet, na hora e lugar que lhes forem convenientes.

\subsection{Latitudes dos não-lugares}

Um dos maiores (senão o maior) marcadores episódicos de Latitudes são as cidades onde a(s) história(s) acontece(m). Cada fragmento da trama que constitui um webisódio/episódio começa, se desenvolve e termina no mesmo local. Desse modo, o que fica evidente desde o título da série, os lugares que a ambientam são extremamente importantes para a compreensão da narrativa. Aqui, assinalamos uma estratégia sutil, mas que funciona para criar identificação com o público pretendido. À medida que Latitudes foi pensada como uma produção transmídia com a navemãe na internet, pressupõe-se que parte significativa de suas audiências estejam minimamente conectadas às redes para consumi-la. Para dialogar com esses 
espectadores, potencialmente espalhados em qualquer lugar do mundo, Latitudes assume um caráter global, trazendo grandes metrópoles mundiais como elementos fundamentais de sua narrativa.

Nesse sentido, Latitudes teve fortes estratégias de divulgação online, principalmente nas redes sociais. Além da página no Facebook, atualizada até julho de 2016, a produção concentra esforços de difusão principalmente no YouTube. Nessa plataforma, são disponibilizados dezenas de vídeos promocionais com trailers dos webisódios, além de entrevistas com Felipe Braga, Alice Braga e Daniel de Oliveira. Também há uma infinidade de hangouts, alguns deles inclusive com parte do elenco ou mesmo o diretor em videoconferência de fora do Brasil - o que determina o caráter internacional de Latitudes e seu potencial de abrangência mundial. O público conectado à internet em qualquer grande cidade do mundo é iminentemente o público de Latitudes.

Quando os centros urbanos assumem essa dimensão na obra, entende-se que ela busca alcançar um nicho específico das audiências, que conhece, tem referências ou ao menos interesse por um estilo de vida cosmopolita, citadino e cotidianamente marcado por viagens internacionais. Um outro aspecto importante de criação de identificação com o público se refere às profisssões escolhidas para os protagonistas. Além de serem jovens globalizados, eles trabalham com o que podem ser consideradas novas profissões na era da internet - ou ao menos profissões que estão profundamente inseridas nas redes digitais. Claro que os trabalhos de editora de moda e fotógrafo, que são os exercidos pelo casal Olívia e José, existiam muito antes do nascimento ou da popularização da internet, mas eles ocuparam um lugar de destaque no contexto digital, principalmente pela possibilidade de difusão quase irrestrita de seus conteúdos. Há muita reverberação em blogs e sites especializados, que fazem com que os conteúdos gerados por esses profissionais tenham grande alcance. Muitos desses blogs e sites amadores, na verdade, se profissionalizam e eles mesmos passam a ser páginas de referência para legiões de seguidores.

Observou-se, no decorrer dos anos, que os blogs assumiam um caráter mais profissional, as apropriações eram variadas; desde um jornalista que mantinha um blog, a um blog corporativo ou, atualmente, blogs que se constituem como mídias. O fenômeno de profissionalização dos blogs tem sido observado pelo Technorati Media. O relatório State of the Blogosphere (2011) apontou que os blogueiros que se declaram - profissionais 
somam $18 \%$ na blogosfera, atrás dos $60 \%$ que dizem manter o blog por hobby. Do total de blogueiros profissionais, $13 \%$ usam o blog para complementar sua renda e os outros $5 \%$ trabalham em período integral com o blog. Se inicialmente as blogueiras de moda, como apontam Rocamora e Bartlett (2009), almejavam apenas demonstrar seu amor pela moda e compartilhar informações sobre o assunto, hoje, elas definem novos nichos comunicacionais e de mercado. (KARHAWI, 2015, p. 6)

A partir da profissionalização do trabalho desenvolvido na web, atividades como as desenvolvidas pelos protagonistas ganham destaque. Esse destaque serve como mais uma ponte entre obra e audiências (sempre bom lembrar o que foi colocado no início desse tópico, falamos de audiências conectadas), que reconhecem o trabalho dos protagonistas. Trabalho esse que gera possibilidades de parcerias profissionais, além da relação amorosa do casal. Essa possível parceria é inclusive discutida por eles em vários momentos da série, quando Olívia insiste que José deveria fotografar moda. Desse modo, segundo ela, os dois poderiam se ver mais, visto o grande envolvimento dos dois com suas respectivas profissões. Mais um elo que une a obra aos jovens com os quais ela conversa, que por vezes almejam trabalhar nas redes em funções de destaque e reconhecidas profissionalmente, assim como o casal em Latitudes. Se houver, além disso, envolvimento afetivo, tanto melhor.

Agora, como estabelecer essa ponte entre Latitudes e sua audiência globalizada a partir de uma produção transmídia independente, com custos restritos de realização? Viajar pelo mundo gravando traz gastos altos e uma saída possível foi reduzir a equipe de produção. Falar das relações entre um casal ao redor do mundo, com foco restrito nos protagonistas, faz com que o elenco da obra seja basicamente constituído por duas pessoas. A não ser nos episódios de São Paulo e Buenos Aires, quando aparecem, respectivamente, a namorada de José e o esposo de Olívia, a trama gira em torno exclusivamente do casal protagonista.

Em um hangout ${ }^{43}$ entre Alice Braga, Felipe Braga e Fabiano Ristow, que assume o papel de "entrevistador", o diretor fala sobre as dificuldades logísticas da gravação em oito países diferentes. Nessa ocasião, a atriz revela que a equipe era composta por nove pessoas, incluindo ela mesma e Daniel de Oliveira. Desse modo, é flagrante a redução da equipe técnica (sete pessoas, tirando os atores) para

\footnotetext{
${ }^{43}$ Disponível no canal de Latitudes no YouTube: https://www.youtube.com/watch?v=A0GWWoAeD5w
} 
que o projeto fosse viável. Do início das filmagens em estúdio (os extras) às cenas do último destino, foi um mês e meio de gravações diárias e intensas ao redor do mundo.

Nessa empreitada, um fator que possivelmente facilitou o processo de gravações se refere à relativa exiguidade de cenas externas. Nesse aspecto, as cidades onde a trama se desenvolve assumem papel referencial, visto que os símbolos que as caracterizam não são tão explorados. Afinal, o que leva lugares cheios de cultura e história, como os centros urbanos que ambientam Latitudes, a serem deixados "de lado", ganhando relevância narrativa os quartos de hotéis, aviões e estações de trens? O que se percebe nesse cenário é o destaque dos nãolugares (Augé, 2008) nos encontros e desencontros do casal José e Olívia.

\begin{abstract}
O lugar e o não-lugar são, antes, polaridades fugidias: o primeiro nunca é completamente apagado e o segundo nunca se realiza totalmente - palimpsestos em que se reinscreve, sem cessar, o jogo embaralhado da identidade e da relação. Os não-lugares, contudo, são a medida da época; medida quantificável e que se poderia tomar somando, mediante algumas conversões entre superfície, volume e distância, as vias aéreas, ferroviárias, rodoviárias e os domicílios móveis, considerados "meios de transporte" (aviões, trens, ônibus), os aeroportos, as estações e as estações aeroespaciais, as grandes cadeias de hotéis, os parques de lazer, e as grandes superfícies da distribuição, a meada complexa, enfim, redes a cabo ou sem fio, que mobilizam o espaço extraterrestre para uma comunicação tão estranha que muitas vezes só põe o indivíduo em contato com uma outra imagem de si mesmo. (AUGÉ, 2008, ps. 74-75)
\end{abstract}

Desse modo, o desenvolvimento dos conflitos entre o casal protagonista é ambientado basicamente em não-lugares. Quarto de hotel em Paris que poderia ser qualquer quarto de hotel no mundo, bar em Londres que poderia ser qualquer bar no mundo, estância no Uruguai que poderia ser qualquer estância no mundo... São espaços de fácil leitura e reconhecimento para qualquer pessoa da audiência. Quando a cidade é identificada ao início do episódio, mesmo que o público nunca tenha ido até lá, saberá quais os códigos de comportamento e o que se espera de um quarto de hotel ou de uma estação de trem.

Mesmo centros urbanos formados há séculos podem hoje conter muitos nãolugares. Eles parecem intrinsecamente o extremo oposto disso, diante da história que suas ruas contam, da cultura guardada em suas construções ou das paixões que levaram sua população a chegar aonde está. No entanto, uma vida globalizada e 
moderna, o desenvolvimento das tecnologias da informação e comunicação e, principalmente, de transportes, estimula a propagação de espaços de fácil assimilação por qualquer um. Um brasileiro desavisado que se localiza em um país do sudeste asiático, por exemplo, e não conhece nada da cultura, língua ou tradições daquele lugar, pode encontrar conforto e segurança ao se deparar com uma grande rede de restaurantes fast food que serve a mesma comida no mundo inteiro. Sobre esse tipo de experiência, Bauman aponta que

Os turistas iniciam suas viagens por escolha - ou, pelo menos, assim eles pensam. Eles partem porque acham o lar maçante ou não suficientemente atrativo, demasiadamente familiar $\mathrm{e}$ contendo demasiadamente poucas surpresas, ou porque esperam encontrar em outro lugar uma aventura mais excitante e sensações mais intensas do que a rotina doméstica jamais é capaz de transmitir. A decisão de abandonar o lar com o fim de explorar terras estranhas é positivamente a mais fácil de tomar pela confortadora percepção de que sempre se pode voltar, se for preciso. Os incômodos dos quartos de hotel pode, de fato, provocar nostalgia, assim como consola e recompensa recordar que há uma casa - em algum lugar -, um refúgio do tumulto e em que a pessoa podia abrigar-se, para estar não-ambiguamente e não problematicamente chez soi - puxar as cortinas, fechar os olhos e ligar os ouvidos a novas sensações, cerras a porta a novas aventuras.... (BAUMAN, 1998, ps. 116-117)

Olívia e José, apesar de evitarem o rótulo de "turistas" por se considerarem habitués das grandes cidades globais, vivem essa rotina que se equilibra entre a liberdade e a segurança. Se Freud (2010) apontava que para conquistarmos a civilização seria necessário renunciarmos aos nossos instintos primitivos, Bauman (1998) segue o raciocínio de perdas e ganhos, agora colocando em um lado da balança a liberdade e, no outro, a segurança. Ao ganharem a liberdade de viajar pelo mundo e se entragarem a novas experiências, Olívia e José abrem mão de aspectos que representariam a segurança em suas vidas afetivas: o lar e que os esperava do outro lado do oceano.

Do mesmo modo, ao mergulharem em países cuja cultura não é familiar, cujos códigos não estão acostumados, a segurança cede espaço para a liberdade. Os não-lugares surgem como apoio para a reconstituição da ordem (Bauman, 1998). Representam, portanto, estabilidade em ambientes desconhecidos, onde as possibilidades estão distribuídas ao acaso. Se em uma medina marroquina o turista brasileiro não sabe o que esperar e pode ser surpreendido com uma cobra sendo enrolada em seu pescoço em troca de uns trocados, no hotel da rede francesa 
instalado a 50 metros dali os acontecimentos são mais organizados para perspectiva do turista: certos deles são altamente prováveis, outros menos e alguns virtualmente impossíveis (Bauman, 1998).

Algumas marcas apresentadas na obra cumprem esse papel de trazer simbolicamente o conhecido a espaços "hostis" de insegurança. Ao almoçar em um ambiente caracterizado pelo imaginário do oriente exótico em Veneza, José abre uma Heineken e traz um elemento de identificação com o público, em meio à profusão de objetos e sons culturalmente distantes. Olívia, por sua vez, viaja por estradas de terra, cruza rios e pradarias em um Fiat. Apesar de a público não saber para onde está sendo levado pela narrativa, repousa na segurança de identificação com o carro, de sua potência e da promessa da marca de que ele não deixará a protagonista "na mão", não importa quão longe ela vá.

Se um lugar pode se definir como identitário, relacional e histórico, um espaço que não pode se definir nem como identitário, nem como relacional, nem como histórico definirá um não-lugar. A hipótese aqui defendida é a de que a supermodernidade é produtora de não-lugares, isto é, de espaços que não são em si lugares antropológicos e que, contrariamente à modernidade baudelariana, não integram os lugares antigos: estes, repertoriados, classificados e promovidos a "lugares de memória”, ocupam aí um lugar circunscrito e específico. (AUGÉ, 2008, p. 73)

Esses ambientes crescem diante de uma tendência à homogeneização da cultura e dos hábitos de consumo dos ditos "cidadão globais". São, além disso, lugares de anonimato. Augé (2008) nos explica que nossa única identidade em um não-lugar está na verificação de um documento ou de um cartão de crédito - essa, muitas vezes, feita por uma máquina. Isso fica claro logo no início do primeiro episódio, quando Olívia e José descobrem os nomes um do outro olhando seus respectivos passaportes. $\mathrm{O}$ casal circula em um mundo sem muitas raízes e com laços afetivos fracos em suas relações com outras pessoas. São habitantes de nãolugares, baseiam sua história a dois em encontros fugazes, onde não transmitem ao outro informações acerca de si mesmos.

Nesse ponto, eles estabelecem uma relação baseada mais em experiências e menos em laços que se pretendam duradouros. A questão é compreender que prazeres podemos extrair do outro, de que modo é possível construir rapidamente uma relação e cuidar para que ela não enraíze a ponto de se tornar difícil para 
demolir depois. Essa lógica baseada em afetos passageiros e marcada por uma série de novos começos é o que Bauman (1998) identifica como identidade de palimpsesto.

\begin{abstract}
Manter o jogo curto significa tomar cuidado com os compromissos de longo prazo. Recusar-se a "se fixar" de uma forma ou de outra. Não se prender a um lugar, por mais agradável que a escala presente possa parecer. Não se ligar a vida ou a uma vocação apenas. Não jurar coerência ou lealdade a nada ou a ninguém. (BAUMAN, 1998, p. 113)
\end{abstract}

Podemos mesmo dizer que grande parte dos encontros entre os dois são quase funcionais. Até certo ponto da narrativa, suas reuniões só ocorriam caso as agendas coincidissem e eles estivessem na mesma cidade por razões profissionais ou, no máximo, faziam discretos ajustes em seus compromissos para que pudessem estar no mesmo (não-) lugar um em companhia do outro. Sempre rapidamente, sempre no intervalo entre um evento e outro. Por vezes, apenas durante a madrugada que dividia um dia de trabalho e a ida, pela manhã, ao aeroporto.

Se por um lado eles baseiam suas vidas compartilhadas em não-lugares, é possível dizer, por outro, que José e Olívia se comportam como não-pessoas. Assim como os não-lugares são quantificáveis, compostos por um espaço físico que os delimita, os dois têm um corpo com o qual se relacionam, mas durante um longo período não avançam. Não compartilham suas histórias, sequer sabem onde fica a casa um do outro. Não revelam seus hábitos, seus gostos ou os relacionamentos que mantêm fora da rotina estafante de viagens profissionais.

Vê-se bem que por 'não lugar' designamos duas realidades
complementares, porém, distintas: espaços constituídos em
relação a certos fins (transporte, trânsito, comércio, lazer) e a
relação que os indivíduos mantêm com esses espaços. Se as duas
relações se correspondem de maneira bastante ampla e, em todo
caso, oficialmente (os indivíduos viajam, compram, repousam),
não se confundem, no entanto, pois os não-lugares medeiam todo
um conjunto de relações consigo e com os outros que só dizem
respeito indiretamente a seus fins: assim como os lugares
antropológicos criam um social orgânico, os não-lugares criam
tensão solitária. (AUGÉ, 2008, p. 87)

Ao mesmo tempo em que esses espaços criam identificação com o público e revelam a personalidade dos dois, fica deflagrada, também a partir deles, sua solidão. Transitam por espaços globalizados, em aviões, trens e táxis, vão a bares pasteurizados que poderiam estar em qualquer grande cidade do mundo e passam suas noites em quartos de hotéis. Não por acaso, os poucos webisódios/episódios 
que são ambientados em lugares orgânicos, em oposição aos não-lugares, acontecem com os cônjuges do casal protagonista. Primeiro, em São Paulo, na casa de José, quando ele conversa com sua namorada. Uma casa de verdade, com mobília e eletrodomésticos. Onde se vive, não por onde se passa rapidamente sem registros - um espaço de identidade do fotógrafo. Depois, em um café em Buenos Aires, onde Olívia dialoga com seu marido. Como o homem faz questão de reiterar, um "lugar de verdade. Com gente de verdade, que vem para ler o jornal e tomar um café, e nada mais". Um lugar onde, veja só, eles não pagam com cartão de crédito, mas com dinheiro em espécie. Longe da sofisticação e da impessoalidade com climatização artificial frequentada pelos protagonistas durante toda a narrativa.

Conclui-se, portanto, que os não-lugares que compõem a história têm duas funções importantes. A primeira é caracterizar os personagens. Eles refletem a sua solidão, a ausência de laços, a rotina de trabalho e de viagens do casal. Localizam Olívia e José como cidadãos do mundo, altamente globalizados, sofisticados e culturalmente ativos. Também dizem muito sobre a sua dificuldade de revelar traços de sua identidade e de compartilhar suas histórias. Falam sobre a solidão em quartos de hotéis de cidades onde não conhecem ninguém e como sentem falta de um lar. Ou de um lugar que possam chamar assim.

Por outro lado, os não-lugares criam um papel fundamental de identificação do público. São espaços criados a partir da cultura de homogeneização do consumo; despertam, portanto, desejo. Quartos luxuosos e bares sofisticados aguçam os sentidos de uma audiência que se interessa pelo requinte dos viajantes que protagonizinam a série. Além disso, ao passar por oito países diferentes, a obra explora a segurança de ambientes onde se sabe o que esperar e como se comportar. É uma redução que facilita a assimilação das audiências de lugares por onde elas talvez nunca tenham passado. Alguém que nunca foi a Londres conseguirá entender que eles estão no bar e qual a razão de estarem ali. Saberá qual bebida consomem pela garrafa ou pelo copo no qual ela é servida. É uma estratégia narrativa, no sentido de não dificultar a compreensão, que exigiria um nível profundo de leitura do produto audiovisual se ele levantasse particularidades de cada um dos lugares por onde passa. É uma estratégia de transmidiação por levar em conta o caráter conectado do público ao qual se refere e a possibilidade de ser encontrada por ele em qualquer plataforma ou ambiente. 


\subsection{Inserção mercadológica: product placement}

Colocando nas mãos do público os eixos centrais da narrativa transmídia, Latitudes propôs uma propagação de seus conteúdos pelos fãs que foram supostamente cativados, em um modelo que proporcionou a chegada da série de televisão e do filme nos cinemas com uma audiência já suposta e previamente constituída pela internet.

Pensar em como os investidores irão inserir seus anúncios em uma produção veiculada em três plataformas diferentes é um desafio que foge aos modelos tradicionais. Latitudes contou com o apoio da $P \& G^{44}$ desde o início da produção, que investiu cerca de um milhão de reais ${ }^{45}$. Além da $P \& G$, outros investidores de Latitudes são a Fiat e a cerveja Heineken.

As marcas foram apresentadas na obra a partir de inserções roteirizadas, que as integram à narrativa de maneira mais natural. Esse modelo constitui o product placement, que encaixam os produtos anunciados no contexto da trama, com cuidado para anunciar marcas a situações, personagens e contextos adequados. Desse modo, Latitudes se ajusta à realidade do financiamento na era do streaming, que já não conta com os anúncios tradicionais durante intervalos comerciais.

José, por exemplo, fotógrafo bem-sucedido e que trabalha viajando pelo mundo, não deixa de tomar uma Heineken durante suas refeições ou em bares sofisticados em grandes capitais européias. Olívia, por sua vez, editora de moda influente no mercado de roupas global, dirige um carro da Fiat compacto, sofisticado e urbano, ditando estilo para mulheres modernas e independentes que acompanham a obra. Sobre o product placement, Miller (2014) esclarece que existem cerca de 35 empresas especializadas em conectar fabricantes e clientes para esse tipo de ação nos Estados Unidos. Basicamente, o trabalho consiste em convencer os anunciantes sobre os benefícios que a inserção de seus produtos em cenografias de títulos de sucesso representa.

Os varejistas e os produtores de bens de consumo pagam a essas empresas cotas de U\$50 mil ou mais para que elas vasculhem centenas de roteiros por ano, nos quais suas marcas e produtos podem ser inseridos. Uma dessas empresas coloca que "legitimamente é a única forma de pagar uma única vez para uma publicidade que ficará aparecendo sempre". (MILLER, 2014, p. 91)

\footnotetext{
${ }^{44}$ Procter \& Gamble $(\mathrm{P} \& \mathrm{G})$ é um conglomerado multinacional que reúne várias empresas de diversos segmentos, desde roupas até produtos de limpeza.

${ }^{45}$ Fonte: http://propmark.uol.com.br/produtoras/45495:marcas-se-unem-a-projeto-transmidia
} 
Além das inserções descritas anteriormente, Latitudes usou outro artifício na divulgação dos patrocinadores. Em outubro de 2013, enquanto a realização seriada ia ao ar no YouTube e na televisão, foi lançado um vídeo de "transformação" de Alice Braga usando produtos da Wella, que pertencem à $P \& G^{46}$. A peça publicitária contou também com a participação de Julio Crepaldi, hair stylist de referência no mundo da beleza e de cosméticos. Dessa forma, o profissional, assim como a atriz, garante legitimidade à marca.

Com pouco mais de dois minutos de duração, o vídeo mostra o preparação estética de Alice Braga para interpretar Olívia. Antes com cabelos longos, ela faz um corte moderno, que valoriza seus cachos e, durante o processo, fala sobre a qualidade dos produtos e como o novo visual ajuda na constituição da personagem. Conta, ainda, sobre como mexeu muito pouco em seus cabelos ao longo da vida e da carreira, apenas duas vezes por conta de papéis que desempenhou em projetos profissionais. Desse modo, é possível perceber a confiança depositada na marca, por parte de alguém que mantém suas madeixas com o mínimo possível de intervenções.

Além de cortar, tratar com produtos Wella e pintar os cabelos, é destacado o aspecto prático da intervenção. Destinado a mulheres modernas e contemporâneas, o novo look não precisa de muita manutenção ou mais de quinze minutos para arrumá-lo e estar pronta para qualquer ocasião, defende Crepaldi. Transformação concluída, são exibidas algumas imagens de Latitudes, com Olívia em um dos webisódios/episódios, já com o visual construído durante as gravações às quais nos referimos.

\footnotetext{
${ }^{46}$ Disponível na página de Latitudes no YouTube: https://www.youtube.com/watch?v=UvHmF9hxIoo
} 


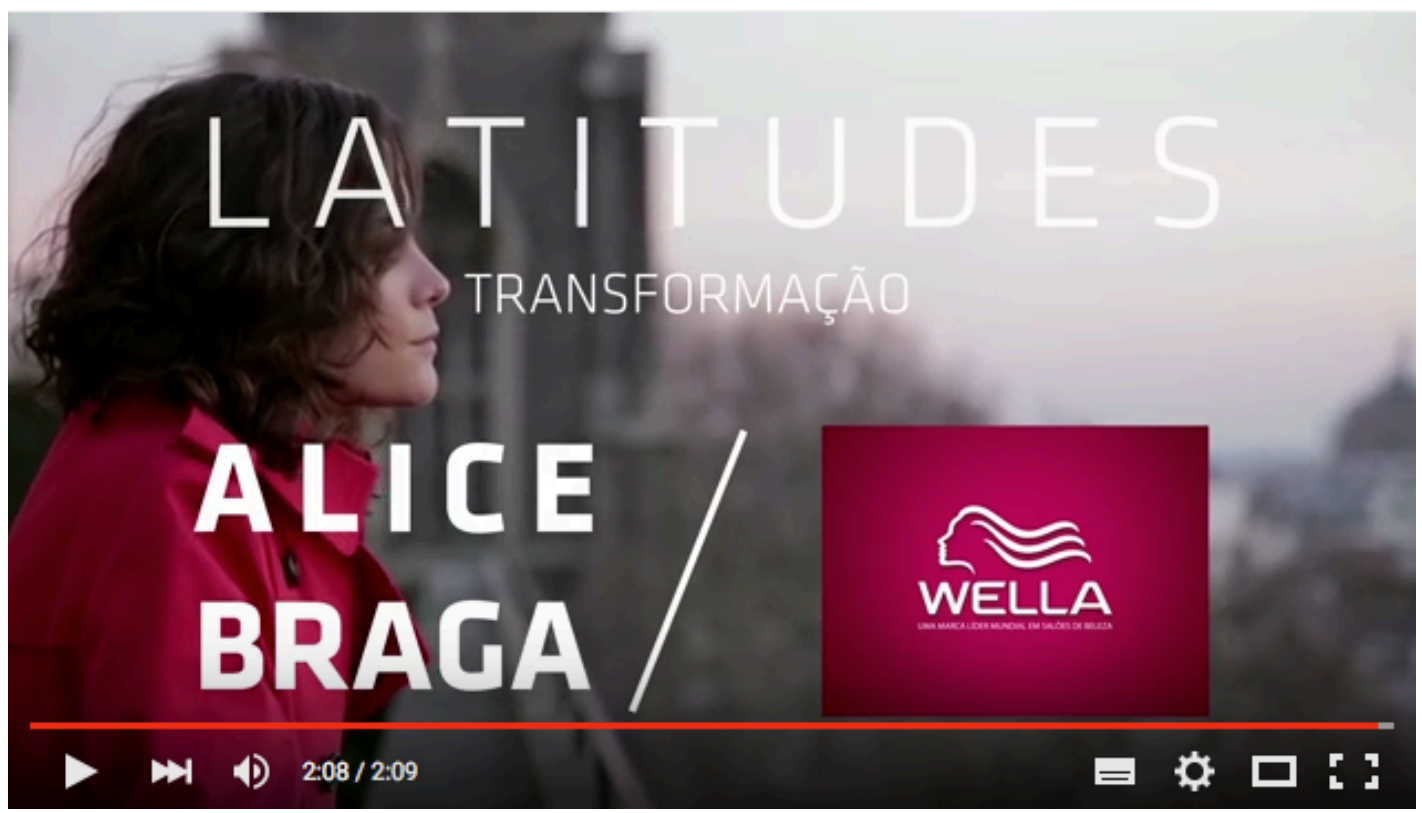

Olívia (Alice Braga) após a transformação usando produtos Wella.

É interessante perceber a escolha criteriosa dos produtos que iriam compor a narrativa, por meio das inserções roteirizadas. São marcas globais, modernas e que se relacionam ao estilo de vida sofisticado e jetsetter de Olívia e José. Certamente, comunicam a um público jovem e antenado que mantém ou almeja os hábitos de consumo da elite internacional e decodifica os símbolos apresentados por meio do product placement. Sem dúvida, é uma estratégia eficiente quando se pensa que a principal plataforma de veiculação da produção, a internet, exige dos realizadores novos modelos e formatos de divulgação dos anunciantes.

No Brasil, apesar de antigo, esse mercado ainda não está tão desenvolvido. Somente há alguns anos o product placement passou a ser considerado como um veículo nas medições do IBOPE Media e esse tipo de publicidade alcançou, em 2013, investimentos que somaram cerca de seis milhões de reais. Como foi medido tal qual um veículo de comunicação, é possível, por meio de uma comparação, perceber que os investimentos em product placement (ou merchandising) ultrapassaram as cifras gastas (em 2013) em publicidade exibida em mídias tradicionais, como rádio, cinema e outdoor (dados do Anuário OBITEL 2014).

Quando falamos sobre distribuição e consumo em streaming, sem os intervalos comerciais tradicionais, o product placement se configura como uma forma eficaz de monetização de conteúdos. Percebe-se, portanto a inserção de 
grandes empresas nesse mercado que até pouco tempo era território de usuários e produtores independentes. Sem dúvida, há uma capitalização da internet e exploração dos modelos de negócio possíveis - e ainda não muito claros - que suas plataformas possibilitam. Esse aspecto traz à luz discussões acerca da profissionalização da realização audiovisual para internet, conforme será tratado adiante.

\begin{abstract}
A lição da nova tecnologia é a mesma de sempre: tal como a imprensa, rádio e televisão, cada meio é rapidamente dominado por corporações centralizadas e centralizadoras, apesar de seu potencial multidistributivo. Esse centralismo é, obviamente, menos poderoso no caso da internet do que no caso das tecnologias mais propensas ao hermetismo (MILLER, 2014, p. $85)$.
\end{abstract}

Latitudes surgiu assim, como uma produção feita com investimentos de grandes anunciantes - e aí talvez inserção na TV e no cinema não tenha sido apenas estratégia ditada pela produção em termos estéticos e de linguagem, mas se relacione com a necessidade de distribuição para grandes públicos, buscando divulgar e reforçar as imagens de marca dos produtos presentes na narrativa. Apesar de não constituir o cerne da narrativa, a televisão não pode ser colocada de lado em um cenário midiático como o constituído no Brasil. Com grandes nomes de atuação nacional e internacional, a obra ocupa um lugar ainda muito habitado por produtores amadores (a internet, nomeadamente o YouTube) e aponta para a profissionalização desse ambiente.

Apesar da inovação, Latitudes investe em um campo muito popular na televisão brasileira e latino-americana: a ficção.

(...) seria bom entender que, ao mesmo tempo que a TV ensaia novos formatos, por exemplo no campo dos reality shows, retorna e refugia-se em seus grandes sucessos do passado, mas reforçando algumas de suas arestas. E os grandes sucessos da TV ibero-americana se concentram na ficção: telenovelas e séries (OROZCO, 2014, p. 104).

É natural que as transformações ocorram a partir da ficção seriada em nosso país, uma vez que é nesse setor que ocorrem as maiores quantidades de produções e o maior volume de investimentos. É esse mundo no qual Latitudes se localiza e o qual, sem sombra de dúvidas, ajuda a transformar a partir da experimentação de novos formatos e modelos de distribuição e consumo desse produto cultural tão 
tradicional no Brasil e que não ficaria de fora da onda transmidiática e do contexto hipertelevisivo da contemporaneidade.

\title{
7.5. O gancho e a fruição em streaming
}

O modelo de distribuição e consumo adotado na obra resulta em uma estratégia relevante da estrutura narrativa de Latitudes: a ausência de ganchos. Os ganchos são o elemento que "encerra o capítulo das narrativas seriadas e prepara já o próximo encontro, quando a história será retomada exatamente no momento da sua ruptura, a partir da cena de corte" (COSTA, 2001, p. 2). Utilizado há milênios para contar histórias, o gancho se popularizou muito a partir dos folhetins impressos e, posteriormente, das narrativas televisuais.

São uma maneira de manter a atenção da audiência, gerando expectativa em relação à continuidade de uma história interrompida em um momento crítico da narrativa. Funcionam satisfatoriamente em sequências episódicas televisionadas diária ou semanalmente, por exemplo. Estimulam que o público esteja disponível, em determinada hora, a fruir conteúdos que seriam inacessíveis de outra maneira.

\begin{abstract}
Inúmeros periódicos, que proliferaram nas décadas de cinqüenta e sessenta do século XX, traziam folhetins que faziam avançar, semana a semana, mês a mês, uma história cheia de ações e emoções, aprimorando-se essa técnica de partir histórias emendando-as já aos capítulos seguintes. Radionovelas e telenovelas, narrativas que se caracterizam pelo desenvolvimento prolongado de tramas, tornaram-se notáveis no uso e abuso de ganchos. As atividades comercias dessas mídias, por outro lado, acabaram impondo novos cortes para a inserção de mensagens publicitárias, o que exigia enredos com apelos cada vez mais intensos, capazes de manter o público "ligado" apesar dessas pausas nem sempre desejáveis. (COSTA, 2001, p. 5)
\end{abstract}

O surgimento do controle remoto, ícone do poder da audiência sobre a programação, e a posterior popularização da TV a cabo estimularam o crescimento e complexificação dos ganchos na indústria televisiva. $\mathrm{O}$ desenvolvimento das tramas passa a ser constantemente interrompido para ter continuidade no "próximo episódio/capítulo", em uma dinâmica que funciona bem para narrativas lineares exibidas sob a lógica broadcast. Em um contexto multimeios e com lógica on demand, como possibilitado pela internet, a eficácia desse recurso pode ser questionada. 
O que se observa em Latitudes é um reflexo da fragmentação dos conteúdos digitais. Desse modo, percebe-se a construção de episódios "fechados" em si. Não que sejam independentes e não remetam todos a uma história comum, mas cada um deles tem começo, meio e fim. Os conflitos apresentados em Paris se resolvem ali, assim como os de Londres ou os de São Paulo. Inclusive, as cidades que ambientam a trama servem como fortes marcadores episódicos - há o "episódio de Veneza" e o "episódio de Istambul", por exemplo; eles não se misturam entre si - o que se passa em uma cidade começa, se desenvolve e termina naquela cidade, sem interrupções ou continuações. Ou seja, sem ganchos.

Não queremos dizer com isso que Latitudes se constitui por oito episódios que não são ligações entre si. Há um eixo narrativo e um desenvolvimento temporal da história, que é indicado ao público. Afinal, vale lembrar que os títulos dos episódios começam sempre indicando qual o número do destino exibido (Primeiro Destino - Paris; Segundo Destino - Londres e assim sucessivamente). Mesmo quando houve a montagem para o cinema, essa estrutura sequencial foi respeitada. No entanto, esse modelo não impede que um indivíduo tenha contato com, suponhamos, o primeiro episódio e, em seguida, com o terceiro ou quarto - pulando o segundo.

\footnotetext{
Além dessa estrutura flexível e circular, colabora para essa comunicação instável, a ausência de uma grade horária e a fraca serialidade dos meios computacionais. Ao contrário do rádio e da televisão, as mídias digitais estabelecem uma relação mais livre, ocasional e informal com o público. As informações se superpõem em camadas, não se sucedem como nos meios convencionais, sendo sempre possível voltar no tempo e acessar o que já passou. (...) Como estabelecer vínculos e medir fidelidades se o ouvinte/usuário pode chegar a qualquer hora e momento? (COSTA, 2001, ps. 10-11)
}

A ausência de ganchos, conforme dito anteriormente, e a ambientação em uma cidade específica atenuam a sensação de estranheza ao se "pular" uma etapa da narrativa. Mesmo os conflitos apresentados não são muito diferentes entre as partes da história, sempre girando em torno da efemeridade dos encontros e da dificuldade de criação de laços entre os protagonistas. Desse modo, a "falta" dos ganchos serve para garantir à audiência a possibilidade de circular quase livremente pela obra, respeitando uma estratégia de distribuição transmídia que via além do modelo de fluxo, mas se adequava à realidade streaming de consumo audiovisual. 


\section{CONSIDERAÇÕES FINAIS}

Ao longo do desenvolvimento desse trabalho, buscamos identificar as estratégias de transmidiação estabelecidas no polo da produção do projeto transmídia Latitudes - disponibilizado de maneira seriada no YouTube, no canal pago TNT e posteriormente em formato longa metragem nos cinemas. Para tanto, realizamos análises detalhadas sobre o cenário da convergência, sobre produções audiovisuais realizadas e/ou adaptadas para a internet e sobre os novos modelos de negócios possíveis no YouTube, uma vez que essa plataforma serviu como repositório da nave-mãe do nosso objeto empírico. No decorrer dos dois últimos capítulos, foram apresentados os resultados principais da investigação, e a partir deles discutimos alguns pontos que retomamos a seguir. A princípio, ficam evidentes questões relativas às mudanças de formato da narrativa em sua circulação entre as mídias. Entre uma websérie, uma série de televisão e um longa metragem, Latitudes se desenvolve com linguagens e estéticas distintas em cada uma das plataformas.

Como etapa final dos esforços para a realização desse trabalho, gostaríamos de abordar perspectivas otimistas acerca da produção audiovisual no cenário de convergência e de múltiplas plataformas, no qual nosso objeto empírico se localiza. A partir das amplas discussões realizadas anteriormente sobre o crescimento da produção não-centralizada, com políticas de incentivo e com os novos processos possibilitados pelos dispositivos digitais, traremos aspectos da profissionalização da realização para a internet e como, a partir deles, é possível pensar em democratização da comunicação no Brasil, onde os grandes veículos de mídia se concentram nas mãos de poucas corporações.

Todas as estratégias estabelecidas na produção de Latitudes revelam um projeto maduro, conectado com a realidade das novas mídias e, ao mesmo tempo, desenvolvido com planejamento. Essa situação reflete uma tendência que vem se desenvolvendo na internet, antes ambiente quase exclusivamente amador, e que agora se profissionaliza gradativamente.

Um fator importante levantado nessa pesquisa se refere à equipe montada

para o desenvolvimento de Latitudes. Trata-se de um time já consagrado na televisão e no cinema, que agora "empresta" seu prestígio para o projeto transmídia. Dessa maneira, a obra ganha, além da credibilidade frente ao público e à crítica, 
uma equipe com know how de produção audiovisual. Esse processo vem crescendo na indústria de entretenimento e de ficção brasileira. Todas as grandes emissoras já contam com extensões de suas narrativas na internet, a exemplo de webséries, blogs de personagens, documentários e extras dos bastidores.

Além disso, diversas produtoras também vêm realizando conteúdos exclusivos para exibição online, identificando o filão de público e mercado nesse ambiente. Essa inserção gera novas dinâmicas de negócios, conforme também foi abordado nesse trabalho. O modelo tradicional de intervalos comerciais vem dando, crescentemente, lugar a anúncios inseridos na própria programação ou em espaços dos sites onde ela é disponibilizada. De qualquer maneira, cada vez mais os ambientes online abrem espaço para a profissionalização de seus conteúdos, que agora coabitam com o amadorismo ${ }^{47}$ que era predominante na origem da produção audiovisual para a internet.

Desse modo, desenhamos um cenário no qual os ambientes online são cada vez menos o lugar para colocar os extras, ou aquilo que não é tão importante para a compreensão das narrativas ficcionais. No caso de Latitudes, o YouTube assume o papel fundamental de comportar a nave-mãe da obra, a partir de onde ela se espalha para as outras plataformas. É um modelo experimental de produção, distribuição e consumo, que confirma a profissionalização potencializada a partir da popularização da internet e, mais que isso, aponta caminhos concretos para a realização audiovisual brasileira.

Realização que, nesse contexto, está cada vez mais fragmentada. Se a televisão e o cinema são os lugares da grande indústria de mídia, a internet cada vez mais se revela como o lugar de destaque do pequeno produtor, daquele com capacidade criativa de inovação e que, sem tantos recursos financeiros, explora novas possibilidades de negócios com os anunciantes. Mesmo os fãs, considerados em certas escalas teóricas e metodológicas tão distante da produção, acham maneiras para interferir nas narrativas. Há exemplos de crowdfunding de

\footnotetext{
${ }^{47}$ Aqui, o amadorismo não se refere a juízos de valor sobre a qualidade das produções, mas ao fato de, tradicionalmente, o trabalho na internet ser feito gratuitamente. Desse modo, os produtores de conteúdo, até muito pouco tempo atrás, não tinham retorno financeiro ou possibilidade de tirar seu sustento das redes, mas trabalhavam basicamente pelo entusiasmo e afinidade emocional com determinadas temáticas ou produtos. A profissionalização colocada em questão nesse ponto da pesquisa começa a subverter essa lógica, de maneira que apontamos meios de capitalizar esse trabalho online e elevar a produção a um nível de qualidade consagrado principalmente pelo audiovisual televisivo brasileiro.
} 
comunidades virtuais que se juntaram e conseguiram realizar, com qualidade, finais alternativos ou extensões narrativas de seus títulos favoritos. Um dos grandes cases de sucesso é Retribution - Star Wars Fan Film, de 2014, um filme que, segundo a descrição de seus produtores, é feito pelos e para os fãs, sem ligação alguma com a trama original Star Wars, com o diretor George Lucas ou com a franquia de mídia criada ao redor da obra original. Um projeto, portanto, criado sem fins lucrativos e apenas para a diversão e reconhecimento da legião de adoradores da saga.

O YouTube enquanto plataforma de distribuição dos conteúdos passa a ser considerado como um caminho para que as realizações alcancem escalas globais e novos modelos de negócios e financiamento se desenvolvam sob a lógica streaming. $\mathrm{Na}$ era da convergência midiática, normatizações das grades horárias televisivas (como a lei do cabo, tratada anteriormente) influenciam a produção de conteúdos para a internet e o trânsito de formatos e plataformas fica evidente na transposição de realizações entre as mídias no intuito de cumprimento das novas exigências legais - principalmente ao se levar em conta que, muitas vezes, os produtores independentes de televisão são os mesmos realizadores de conteúdos disponibilizados online.

Desse modo, estamos em um ambiente que oferece uma gama cada vez maior de produções amplamente aceitas por suas audiências. Além disso, são também acessíveis on demand, sem as "amarras" da grade horária televisiva ou os preços muitas vezes abusivos cobrados no circuito comercial de cinema brasileiro. Esse ponto, aliás, é de fundamental importância se quisermos pensar na democratização da comunicação possível a partir das novas perspectivas trazidas com a transmidiação e com a produção de conteúdos para disponibilização online. A gratuidade da "programação" gera novas dinâmicas comerciais e de consumo e é seminal no debate sobre acesso a entretenimento e informação horizontalizado e sob uma perspectiva mais abrangente e inclusiva.

Por outro lado, cabe destacar que a partir da sofisticação tecnológica, novas formas de comunicar foram sendo estabelecidas. Com a fragmentação vivenciada na contemporaneidade e exposta anteriormente, a potencialidade de produção e distribuição de conteúdos nas redes chegou a nichos sociais aos quais antes era inalcançável. Se antes o aparato técnico para a realização audiovisual era um grande impedimento, hoje há alternativas para superá-lo. Sejam celulares, tablets ou câmeras portáteis, há uma gama de aparelhos cada vez mais acessíveis a grupos 
independentes e mesmo iniciativas individuais, que agora podem assumir a produção de conteúdos participativos compartilhados online.

A potencial pluralidade de realizadores contribui para a democratização da comunicação, tendo as redes como fatores centrais dessa transformação. Quando se fala na mídia brasileira, é impossível que não se associe a ela o termo "concentração". Um breve quadro da conjuntura nacional foi traçado para essa pesquisa e é importante não perdê-lo de vista, mesmo quando falamos dos avanços conseguidos por meio da internet. A comunicação no Brasil, portanto, está historicamente nas mãos de poucos grupos. A produção de informação e entretenimento é um negócio caro, que, agora, vislumbra timidamente novos horizontes.

A multiplicação de vozes compondo o mercado midiático, como dito anteriormente, leva a grandes perspectivas de democratização. Desde a diversidade de posicionamentos ideológicos até o atendimento a demandas de conteúdos regionais ou de nichos, quando se fala em ficção, por exemplo, são vários fatores que abrilhantam o cenário mais pluralizado. A diminuição do alcance hegemônico da grande indústria da comunicação e o crescimento de atores mais variados é um processo que deve, inclusive, enriquecer as narrativas sobre os "Brasis" que cabem em um só país, além de fomentar o diálogo entre grupos sociais específicos e historicamente marginalizados, que, muitas vezes, não são representados ou mesmo contemplados pelos grandes veículos que dominam o mercado.

Apesar disso, é preciso levar em conta que a internet não pode ser encarada como a salvação da comunicação e da democracia em um país onde ela ainda não é acessível a uma imensa parcela da população. Grande parte Brasil profundo (Alves, 2003) ainda opera de maneira analógica, longe do boom digital que marca os avanços tecnológicos na contemporaneidade. Nesse contexto, é importante levar em conta a força que veículos como rádio e televisão ainda têm na conjuntura nacional. De acordo com dados do Instituto Brasileiro de Geografia e Estatística (IBGE), somente em 2015 o acesso à internet chegou a contemplar cerca de metade da população nacional ${ }^{48}$. Essa metade do Brasil conectada se concentra principalmente nos estados do sudeste (57\%), sul (53,5\%) e centro-oeste (54,3\%). Desse modo, percebe-se que as todas as regiões do país - mas especialmente o norte $(38,6 \%)$ e o

48 Disponível em: http://tecnologia.uol.com.br/noticias/redacao/2014/09/18/mais-da-metade-dapopulacao-tem-acesso-a-internet-aponta-a-pnad.htm (acesso em 09 de maio de 2016). 
nordeste $(37,2 \%)$ - ainda carecem de investimentos em tecnologias de acesso à rede mundial de computadores.

Dentro desse universo de conexões, o suporte de acesso às redes no Brasil também tem características peculiares. Em 2014, por exemplo, o número de lares com computadores diminuiu, se aproximando de metade dos domicílios ${ }^{49}$. É perceptível que esse fenômeno se configura, entre outros fatores, pela popularização de aparelhos celulares, que, de acordo com dados da mesma pesquisa, já compõem o maquinário doméstico de 34,6 milhões (ou 51,4\%) de residências no país. É importante levar em consideração esse contexto de internet acessada por meio de dispositivos móveis para se traçar um panorama com perspectivas de democratização da comunicação no Brasil.

Todo esse processo gera uma rede que, apesar de não ser amplamente democrática, configura uma massa enorme de usuários que antes não tinham acesso a alternativas de comunicação fora do circuito de mídias tradicionais. Formam, portanto, audiências antes restritas a grandes emissoras de televisão e que agora estão potencialmente "disponíveis" para consumir programações alternativas e feitas de maneira independente. Novamente, a gratuidade da internet assume grande importância nesses novos processos de difusão audiovisual. Além de latente público consumidor de informações e entretenimento, esses internautas passam também a ter possibilidade de produzir seus próprios conteúdos - diante do barateamento e popularização das tecnologias de gravação e veiculação.

Segundo o sociólogo Manuel Castells (2006), existe um novo modelo de comunicação pessoal, que se baseia no controle individual e na partilha coletiva da informação. Os dispositivos móveis e a internet seriam as ferramentas por meio das quais esse modelo se tornaria possível, dando acesso a uma gama plural de informações e conteúdos. Esse potencial tem sua importância multiplicada no Brasil, onde a informação e a comunicação são direitos negados a grande parte da população, devido à concentração de mídia que se configura como um traço histórico do país. Além disso, por meio da maturidade dessa convivência com fontes e perspectivas diversas, os próprios marginalizados poderiam passar a

49 Disponível em: http://www.avellareduarte.com.br/fases-projetos/conceituacao/demandas-dopublico/pesquisas-de-usuarios-atividades-2/internet-no-brasil-2015-dados-e-fontes (acesso em 09 de maio de 2016). 
produzir seus próprios conteúdos. E um ponto fundamental dessa estrutura é o seu alcance global.

São práticas comunicacionais, portanto, que oferecem à sociedade maiores níveis de controle e intervenção. Também tratam de incluir agentes marginalizados pela grande mídia, potencializando o número de vozes e discursos. Ainda não é a constituição exata do cenário brasileiro, mas acreditamos que a inserção de produtores independentes no mercado é um percurso que inaugura esse processo. Observar que esses produtores adotam a internet como veículo central de distribuição de seus conteúdos (gratuitamente), também aponta para esse caminho de popularização. Percebemos, portanto, que não se trata apenas de um case de sucesso de produção audiovisual ficcional transmídia, mas, principalmente, de um experimento que contesta a lógica das grandes emissoras e produtoras e aproxima o mercado brasileiro de uma perspectiva de democratização da comunicação e do entretenimento, usando como ferramentas principais as ainda timidamente exploradas potencialidades da internet no país.

Fica, portanto, o espaço para futuras análises do desdobramento desse cenário de convergência e potencial democratização da realização e consumo de produções audiovisuais brasileiras. Latitudes se configura como uma tendência, mas o campo de estudos permacene aberto para a confirmação da ação de políticas afirmativas e da internet no processo de ruptura da hegemonia e concentração midiáticas no mercado das comunicações brasileiro. 


\section{REFERÊNCIAS BIBLIOGRÁFICAS}

ADAM, J-M. Le texte narratif. Paris: Nathan, 1985.

AFFINI, Letícia Passos. Conteúdo audiovisual: especificidades dos dispositivos móveis e da internet. In: Congresso Brasileiro de Ciências da Comunicação, XXI, 2008. Natal. Anais...São Paulo: Intercom, 2008.

ALVES, Marcio Moreira. História do Brasil profundo. São Paulo: Nova Fronteira, 2003.

AUGÉ, Marc. Não-lugares - Introdução a uma antropologia da supermodernidade. Campinas: Papirus, 2008.

BAKHTIN, M. Estética da criação verbal. São Paulo: Martins Fontes, 2003.

BAKHTIN, M./ VOLOCHINOV, V. N. (2002). Marxismo e Filosofia da

Linguagem. São Paulo: Editora Hucitec, 2002.

BAKHTIN, Mikhail. Problemas da poética de Dostoiévski. São Paulo: Forense Universitária, 2008.

BARTHES, Roland. S/Z. Rio de Janeiro: Nova Fronteira, 1992.

BARTHES, Roland. Introdução à análise estrutural da narrativa. In: BARTHES, Roland et al. (Orgs.). Análise Estrutural da Narrativa. Petrópolis: Editora Vozes, 2009.

BAUMAN, Zygmunt. O mal-estar da pós-modernidade. Rio de Janeiro: Zahar, 1998.

BEZERRA, Paulo. Polifonia. In: BRAIT, Beth (Org.). Bakhtin: conceitos-chave. $4^{\mathrm{a}}$ ed. São Paulo: Contexto, 2008. p. 191-200, 2005.

BOUMANS, Jack. Cross-media on the advance. (p. 127-141) In: BRUCK, P.A. (et al.) (ed). E-Content: technologies and perspectives for the European market. Berlin-Heildelberg: Springer, 2005.

BURGESS, Jean; GREEN, Joshua. YouTube e a Revolução Digital. São Paulo: Aleph, 2009.

CALABRESE, Omar. A idade neobarroca. Lisboa, Portugal: Edições 70, 1988.

CANNITO, Newton. A televisão na era digital. São Paulo: Summus, 2010

CARLÓN, M. Contrato de fundação, poder e midiatizaçãoo: notícias do front sobre a invasão do YouTube, ocupação dos Bárbaros. In MATRIZes - Revista do Programa de Pós-Graduação em Ciências da Comunicação da Universidade de São Paulo (Vol. 01, Cap. 5, pp. 107-126). São Paulo: ECA/USP, 2013. 
CASTELLS, M. Communication power. New York: Oxford University Press, 2009.

CASTELLS, Manuel. A Sociedade em Rede: do conhecimento à política. In: CASTELLS, Manuel; CARDOSO, Gustavo (orgs.). A Sociedade em Rede: do conhecimento à acção política. Lisboa: Centro Cultural de Belém, 2006.

CASTELLS, Manuel. Internet e Sociedade em Rede. In: MORAES, Denis de (org.) Por uma outra comunicação. Rio de Janeiro: Record, 2003.

CASTILHO, Fernanda Santana. Teletube: novos passeios pelos bosques da ficção televisiva. 2014. 287 f. Tese (Doutorado em Ciências da Comunicação). Faculdade de Letras, Universidade de Coimbra, Coimbra, Portugal. 2014.

COSTA, Maria Cristina Castilho. O gancho - da mídia impressa às mídias eletrônicas. In: Congresso Brasileiro de Ciências da Comunicação, XXIV, 2011. Campo Grande. Anais... São Paulo: Intercom, 2011.

COSTELLO, Victor; MOORE, Barbara. Cultural outloaws: an examination of audience activity and on-line television fandom. Television \& New Media, v. 8, n. 2, p. 124-143, 2007.

DIONNE, Jean; LAVILLE, Christian. A Construção do Saber: manual de metodologia da pesquisa em ciências humanas. Belo Horizonte: Editora UFMG, 1999.

ECO, Umberto. (1983) La estrategia de la Ilusión - TV: la transparencia perdida, 1983.

ECO, Umberto. Seis Passeios pelos bosques da ficção. São Paulo: Companhia das Letras, 1994.

EZQUENAZI, Jean-Pierre. Les Séries Télévisées: L'avenir du cinéma? Paris: Armand Colin, 2010.

FECHINE, Y ; CARLÓN, M (orgs). O Fim da Televisão. Rio de Janeiro: Confraria do Vento, 2014.

FECHINE, Y. Como pensar os conteúdos transmídias na teledramaturgia brasileira? Uma proposta de abordagem a partir das telenovelas da Globo. In M. I. V. LOPES (Org.). Estratégias de Transmidiação na Ficção Televisiva Brasileira (Vol. 3, Cap. 1, pp. 19-60). Porto Alegre: Ed. Sulina, 2013.

FECHINE, Yvana. Transmidiação e cultura participativa: pensando as práticas textuais de agenciamento dos fãs de telenovelas brasileiras. In: Encontro Anual da Compós, XXIII, 2014. Belém. Anais... Salvador: EDUFBA, 2014.

FISKE, J. Television Culture. New York: Routledge, 1987. 
FREUD, Sigmund. O mal-estar na civilização e outros textos. São Paulo: Companhia das Letras, 2010.

GRECO, Clarice. Qualidade na TV: telenovela, crítica e público. São Paulo: Atlas, 2013.

GREGOLIN, Rosário. Foulcault e Pêcheux na análise do discurso: diálogos e duelos. São Carlos: Editora Claraluz, 2005.

HAMBURGER, K. A lógica da criação literária. São Paulo: Perspectiva, 1986.

JENKINS, H; GREEN, J; FORD, S. Cultura da Conexão. São Paulo: Aleph, 2014.

JENKINS, H. Cultura da Convergência. São Paulo: Aleph, 2008.

JENKINS, H. Lendo criticamente e lendo criativamente. In MATRIZes - Revista do Programa de Pós-Graduação em Ciências da Comunicação da Universidade de São Paulo (Vol. 02, Cap. 1, pp. 11-24). São Paulo: ECA/USP, 2012.

JENKINS, H. Transmedia 202: Further Reflections. Confessions of an Aca-Fan. The Official Weblog of Henry Jenkins. Disponível em: http://henryjenkins.org/2011/08/defining_transmedia_further_re.html

JOST, François. La promesse des genres. Réseaux, n. 81, CNET - 1997. Disponível em: http://www.enssib.fr/autres-sites/reseaux-cnet/81/01-jost.pdf. Acesso em: 10 mai. 2016.

KARHAWI, Issaaf Santos. "Sou blogueira da Capricho": um ensaio sobre as formações discursivas. In: Congresso Internacional IBERCOM, XIV, 2015. São Paulo. Anais... São Paulo: IBERCOM, 2015.

KARHAWI, Issaaf Santos. Blog de personagem: discurso e dialogia na produção de sentidos entre internautas e personagens da minissérie Afinal, o que querem as mulheres?. 2013. 164 f. Dissertação (Mestrado em Ciências da Comunicação). Escola de Comunicações e Artes, Universidade de São Paulo, São Paulo, 2013.

LATOUR, B. Reassembling the Social: An introduction to Actor-NetworkTheory. New York: Oxford University Press, 2005.

LIVINGSTONE, Sonia. Audiences and publics: when cultural engagement matters for the publicsphere. Bristol, UK: Intellect, 2005.

LIVINGSTONE, Sonia. The challenge of changing audiences: or, what is the audience researcher to do in the age of the internet? European Journal of Communication, n. 19, v. 1, ps. 76-86, 2004.

LOPES, M. I. V; MUNGIOLI, M. C. P. A autoconstrução do fã: performances e estratégias de fãs de telenovela na internet. In: LOPES, Maria Immacolata Vassalo 
de (org). Por uma teoria de fãs na ficção televisiva brasileira. Porto Alegre: Editora Meridional, 2015, ps. 17-64.

LOPES, M. I. V; MUNGIOLI, M. C. P. Brasil: a telenovela como fenômeno midiático. In: LOPES, Maria Immacolata Vassalo de; OROZGO, Guillermo (orgs). Memória Social e Ficção Televisiva em Países Ibero-americanos. Porto Alegre: Editora Sulina, 2013, ps. 129-168.

LOPES, M. I. V; MUNGIOLI, M. C. P. Brasil: tempo de séries brasileiras?. In: LOPES, Maria Immacolata Vassalo de; OROZGO, Guillermo (orgs). Relações de Gênero na Ficção Televisiva. Porto Alegre: Editora Sulina, 2015, ps. 117-160.

LOPES, M. I. V; MUNGIOLI, M. C. P. Brasil: trânsito de formas e conteúdos na ficção televisiva. In: LOPES, Maria Immacolata Vassalo de; OROZGO, Guillermo (orgs). Estratégias de Produção Transmídia na Ficção Televisiva. Porto Alegre: Editora Sulina, 2014, ps. 119-160.

LOPES, M. I. V.; OROZCO, G. G. (orgs.) Estratégias de Produção Transmídia na Ficção Televisiva. Porto Alegre: Ed. Sulina, 2014.

LOPES, M. I. V. de; MUNGIOLI, M. C. P. Ficção televisiva transmidiática: temáticas sociais em redes sociais e comunidades virtuais de fãs. In: LOPES, M. I. V. de. (Org.) Ficção televisiva transmidiática no Brasil: plataformas, convergência e comunidades virtuais. Porto Alegre: Sulina, 2011.

LOPES, M. I. V. Sobre o estatuto disciplinar do campo da Comunicação. In: LOPES, M. I. V. (org.). Epistemologia da Comunicação. São Paulo: Loyola, p. 277 a 293, 2003.

LOPES, M. I. V. Telenovela brasileira: uma narrativa sobre a nação. Comunicação e Educação, São Paulo, ps. 17-34, 2003.

LUSVARGHI, Luiza Cristina. O cinema na era digital: a consolidação dos conteúdos cross-media no Brasil, de Big Brother ao caso Antonia. In: Congresso Brasileiro de Ciências da Comunicação, XXX, 2007. Santos. Anais... São Paulo: Intercom, 2007.

MACHADO, A.; VÉLEZ, M. L. Fim da Televisão? In: FECHINE, Y; CARLÓN, M (orgs). O Fim da Televisão. Rio de Janeiro: Confraria do Vento, 2014.

MACHADO, Arlindo. A televisão levada a sério. 4 ed. São Paulo: SENAC, 2000.

MANOVICH, Lev. The Language of New Media. Cambridge, Massachusetts: Massachusetts Institute of Technology, 2001.

MARTEL, Frédéric. Mainstream: a guerra globas das mídias e das culturas. Rio de Janeiro: Editora Civilização Brasileira, 2012.

MARTÍN-BARBERO, Jesús. Dos meios às mediações: comunicação, cultura e hegemonia. Rio de Janeiro: Editora UFRJ, 2001. 
MASSAROLO, J. Storytelling Transmídia: Narrativa para multiplataformas.

Tríade. 02, 335-347, 2013.

MASSAROLO, João Carlos; MESQUITA, Dario. Reflexões teóricas e metodológicas sobre as narrativas transmídia. In: Encontro Anual da Compós, XXIII, 2014. Belém. Anais... Salvador: EDUFBA, 2014.

MATTELART, Armand; MATTELART, Michèle. O carnaval das imagens: a ficção na tv. São Paulo: Brasiliense, 1989.

MILLER, Toby. O Agora e o Futuro da Televisão. In: FECHINE, Y; CARLÓN, M (orgs). O Fim da Televisão. Rio de Janeiro: Confraria do Vento, 2014.

MITTEL, J. Narrative Complexity in Contemporary American Television. The Velvet Light Trap, n. 58, fall of 2006. University of Texas Press, Austin, 2006.

MITTEL, J. Notes on Rewatching. JustTV, janeiro de 2011. Disponível em: http://justtv.wordpress.com/2011/01/27/notes-on-rewatching/, 2011.

MORIN, Edgar. Introdução ao pensamento complexo. Porto Alegre: Sulina, 2005.

MOTTER, Maria Lourdes; MUNGIOLI, Maria Cristina Palma. Serialidade: o prazer de re-conhecer e pré-ver. Anais, XXIX Congresso Brasileiro de Ciências da Comunicação - UnB - 6 a 9 de setembro de 2006.

MUNGIOLI, M. C. P. Minissérie Grande Sertão Veredas: Gêneros e Temas Construindo um Sentido Identitário de Nação. 2006. 290 f. Tese (Doutorado em Ciências da Comunicação). Escola de Comunicações e Artes, Universidade de São Paulo, São Paulo. 2006.

MUNGIOLI, M. Cristina Palma; PENNER, Tomaz A. O universo narrativo de Latitudes: a reassistibilidade como estratégia de transmidiação. Revista GEMInIS, São Carlos, ano 5, n 2, p. 110-122, 2014.

MUNGIOLI, Maria Cristina Palma. Gêneros Televisuais e Discurso: enunciação, ficcionalidade e interação na série Norma. Revista Comunicação, mídia e consumo, São Paulo, ano 9, vol. 9, n. 24, p. 97-114, mai. 2012.

MURAKAMI, Mariane Harumi. Narrativas em Diálogo: A Experiência da Telenovela em Múltiplas Plataformas. Novos Olhares, São Paulo, p. 58-71, junho 2012.

MYERS, David. Psicologia. Rio de Janeiro: L. T. C., 2006.

NAVARRO, V. Sites of Convergence: an interview with Henry Jenkins. Revista CONTRACAMPO, 21, 02-26, 2010. 
ORLANDI, Eni P. Análise do discurso: princípios e procedimentos. Campinas, SP: Pontes, 2009.

OROZCO, G. Televisão: causa e efeito de si mesma. In: FECHINE, Y; CARLÓN, M (orgs). O Fim da Televisão. Rio de Janeiro: Confraria do Vento, 2014.

ORTIZ, Renato; BORELLI, Sílvia e RAMOS, José M.O. Telenovela - História e produção. São Paulo: Brasiliense, 1989.

PALLOTTINI, Renata. Dramaturgia de televisão. São Paulo: Moderna, 1998.

PELEGRINI, C. H. A poética do cômico em Arrested Development e a reassistibilidade. Palabra Clave 15 (3), 621-648, 2012.

PEREIRA, R. C.; RODRIGUES, R. H. Os Gêneros do Discurso sob Perspectiva de Análise Dialógica de Discurso do Círculo de Bakhtin. Letras, Santa Maria, v. 20, n. 40, p. 147-162, jan./jun. 2010.

RIZZOTTO, Carla Candida. Constituição histórica do poder na mídia no Brasil: o surgimento do quarto poder. Revista de Estudos da Comunicação, Curitiba, v. 13, n. 31, ps. 111-120, maio/agosto 2012.

RODRIGUES, R. H. Análise de gêneros do Discurso na Teoria Bakhtiniana: algumas questões teóricas e metodológicas. Linguagem em (Dis)curso, Tubarão, v. 4, n. 2, p. 415-440, jan./jun. 2004.

RODRIGUES. R. H. A constituição e funcionamento do gênero jornalístico artigo: cronotopo e dialogismo. Tese (doutorado em Linguística aplicada e Estudos da Linguagem) - Pontifícia Universidade Católica de São Paulo, São Paulo, 2001.

ROYCE, W. Managing the Development of Large Software Systems: concepts and techniques. In: International Conference on Sowftware Engeneering, 9., 1970, Califórnia. Proceedings of the 9th International Conference on Software Engeneering, Califórnia, p. $328-338,1970$.

RYAN, M-L. On the theoretical foundations of transmedial narratology. In MEISTER, J. C. (Ed.) (2005). Narratology Beyond Literary Criticism: Mediality, Disciplinarity. Berlin: Walter de Gruyter, 2005.

SACRINI, Marcelo. Perspectivas do gênero Documentário pela apropriação de elementos de linguagem da TV Digital Interativa. ETD Educação Temática Digital, Campinas, SP, v.5, n.2, p. 7-22, 2004. 
SANTINI, Rose Marie; CALVI, Juan C. O consumo audiovisual e suas lógicas sociais na rede. Comunicação, Mídia e Consumo. São Paulo, vol. 10, n 27, ps. 159-182, 2013.

SCOLARI, Carlos A. This is The End: as intermináveis discussões sobre o fim da televisão. In: FECHINE, Y; CARLÓN, M (orgs). Fim da Televisão. Rio de Janeiro: Confraria do Vento, 2014.

SCOLARI, Carlos. La estética post-hipertextual. Palestra realizada no Seminário Internacional Las Literaturas del Texto al Hipertexto / Literatures from text to hypertext. Madrid: UMC (publicada en Romero López, D. y Sanz Caberizo, A. (eds.) Literaturas del texto al hipermedia. Barcelona: Anthropos, 2006.

SCOLARI, Carlos. Narrativas trasmedia: cuando todos los medios cuentam. Barcelona: Deusto, 2013.

SHIRKY, Clay. A Cultura da Participação: criatividade e generosidade no mundo conectado. Rio de Janeiro: Zahar, 2011.

SILVA, Marcel Vieira Barreto. Cultura das séries: forma, contexto e consumo de ficção seriada na contemporaneidade. In: Galáxia, n. 27, ps. 241-252, 2014.

SOUSA, Ana Paula da Silva e. Lei da TV paga: até que ponto a restrição a produtos estrangeiros estimula a produção local. In: V Seminário Internacional Políticas Culturais - Setor de Políticas Culturais Fundação Casa de Rui Barbosa, Rio de Janeiro, 2014.

TODOROV, Tzevan. As Estruturas Narrativas. São Paulo: Perspectiva, 2011

TODOROV, Tzevan. As categorias da narrativa literária. In: BARTHES, Roland et al. (Orgs.). Análise Estrutural da Narrativa. Petrópolis: Editora Vozes, 2009.

UNESCO. World Report, Investing in Cultural Diversity and Intercultural Dialogue, p.18-19, 2009.

WOLTON, Dominique. Elogio do grande público: uma teoria crítica da televisão. São Paulo: Editora Ática, 1996.

ZANETTI, Daniela. Repetição, Serialização, Narrativa Popular e Melodrama. In MATRIZes - Revista do Programa de Pós-Graduação em Ciências da Comunicação da Universidade de São Paulo (Vol. 02, Ano. 2, pp. 181-194). São Paulo: ECA/USP, 2009. 